九州大学学術情報リポジトリ

Kyushu University Institutional Repository

\title{
Upper Cretaceous Ammonites of California Part II
}

Matsumoto, Tatsuro

Department of Geology, Kyushu University

https://doi.org/10.5109/1546811

出版情報：九州大學理學部紀要：Series D, Geology. Special vol. 1，pp.1-172，1959-11-10. Faculty of Science, Kyushu University

バージョン :

権利関係 : 
Mem. Fac. Sci., Kyushu Univ., Ser. D, Geology, Special Volume I,

pp. $1-172$, text-figs. $1-80$; pls. $1-41$, November 1959

\title{
Upper Cretaceous Ammonites of California
}

\author{
Part $\mathrm{II}^{*}$ \\ $\mathrm{By}$ \\ Tatsuro Matsumoto \\ Systematic Descriptions
}

Part B. Ammonoids other than baculitids

Family Phylloceratidae ZITTEL, 1884

Representatives of the family Phylloceratidae occur rather sporadically in the Upper Cretaceous of the West Coast of North America. In California I have recognized examples of the two genera, Neophylloceras and Phyllopachyceras. As the last genus is represented by imperfectly preserved specimens, I exclude here its description. Partschiceras (?) japonicum (MAтsumoto), which has recently been discovered in the probable Cenomanian of Alaska (MATsumoto, 1959a, p. 52, pl. 12, figs. 1a-c, 2a, b, 3a-c; text-fig. 2), has not yet been confirmed in California.

Genus Neophylloceras Shimizu, 1934

Type-species.-Ammonites (Scaphites ?) ramosus MeEK, 1857.

Synonym.-Hyporbulites BREISTROFFER, 1947.

Diagnosis.-See Wright and Matsumoto, 1954, p. 109.

Remarks.-The relationship of Neophylloceras MEEK, 1857 with Hypophylloceras SPATH, 1927 and the synonymy of Hyporbulites BREISTROFFER, 1947 with Neophylloceras MEEK, 1857 were discussed, when I described Neophylloceras seresitense (Pervinquière) from Alaska (MAtsumoto, 1959a, p. 55). That species occurs also in California. It was described by ANDERson (1958, p. 180, pl. 16, fig. 4, 4a) as Phylloceras velledae. One of ANDERson's two hypotypes, from loc. CAS. 2233, a locality of Calycoceras cf. newboldi (KoSSMAT), is evidently an example of $N$. seresitense. The other, from loc. CAS. 31097, was not at my disposal.

Neophylloceras ramosum (MEEK)

Pl. 1, fig. 1a-d; Pl. 2, fig. 2; Pl. 8, fig. 1a-c

1857. Ammonites (Scaphites ?) ramosus MEEK, Trans. Albany Inst., vol. 4, p. 45.

1876. Phylloceras ? ramosum, MeEk, Bull. U. S. Geol. Geogr. Surv. Terr., vol. 2, no. 4, p. 371, pl. 5, fig. 1, 1a, $1 \mathrm{~b}$.

1903. Phylloceras ramosum, Whiteaves, Mesozoic Fossils. vol. 1, pt. 5, p. 327.

* Received July 9, 1959. Continued from Part I (Mem. Fac. Sci., Kyushu Univ., Ser. D, Geology, Vol. VIII, No. 4, pp. 91-171, text-figs. 1-85, pls. 30-45, March 1959). 
? 1928. Phylloceras aff. ramosum, Collignon, Ann. Paléont., vol.17. p. 7, pl. 1, figs. 2-4.

1934. Neophylloceras ramosum, Shimizu, in SHIMizu \& OBATA, Cephalopoda, p. 62.

1942. Neophylloceras ramosum, Matsumoto, Proc. Imp. Acad. Japan, vol. 18, p. 674.

1942. Neophylloceras compressum Matsumoto, Proc. Imp. Acad. Japan, vol. 18 , p. 675 , text-fig. $1 a_{2}, b_{2}$.

1952. Neophylloceras ramosum, Usher, Geol. Surv. Canada, Bull. 21, p. 49, pl. 1, figs. 4, 5 .

1958. Phylloceras ramosum, Anderson, Geol. Soc. Amer., Memoir 71, p. 181, pl. 40, fig. 4, 4 a.

1958. Phylloceras vaculum Anderson, Geol. Soc. Amer., Memoir 71, p. 181, pl. 40 , fig. 3 , $3 \mathrm{a}, 3 \mathrm{~b}$.

? 1958. Phylloceras pachecoense Anderson, Geol. Soc. Amer., Memoir 71, p. 182, pl. 53, fig. 1, 1 a.

Holotype.-USNM. 12451, from "Komooks, Vancouver Island".

Material.-The Californian examples which I refer to the present species are as follows:

GK. H7001, from loc. TM. 2001 [=LSJU. 3288=CIT. 1346] (Coll. W. P. Popenoe \& T. MATSUmoto)

"Holotype (CIT. 3726) (Pl. 8, fig. 1a-c) and paratype of Phylloceras vaculae Anderson", from loc. CIT. 1346 (Coll. W. P. Popenoe)

Specimens from loc. LSJU. 2006 (Coll. J. M. KIRBY)

Fragmentary specimens from loc. LSJU. 2709 (Coll. W. E. KENNETT \& Stanley McCoY)

An immature shell, LSJU. 8605, from loc. LSJU. 2735 (Coll. L. W. FunKSHOUSER)

A specimen from loc. UCLA. 3642 (Coll. L. E. \& R. B. SAUL)

A specimen from loc. UC. A-7581 (Coll. UC. Paleontology Class 137, 1951)

Doubtfully referable specimens, "holotype and other examples of Phylloceras pachecoense ANDERSON", from loc. CAS. 29108

Several fragments, some of which show well-exposed sutures and mode of ribbing, from loc. CAS. 1467 (no record of collector)

A comparable specimen from loc. CAS. 31245 (Coll. McCoY)

Measurements.*-

\begin{tabular}{|c|c|c|c|c|c|}
\hline $\begin{array}{c}\text { Specimen } \\
\text { USNM. } 12451\end{array}$ & $\begin{array}{l}\text { Remarks } \\
\text { maximum }\end{array}$ & $\begin{array}{c}\text { Diameter } \\
47.1\end{array}$ & Height & Breadth $(\mathrm{B} / \mathrm{H})$ & Umbilicus $(\%)$ \\
\hline 'I & $\begin{array}{l}1 / 4 \text { vol. } \\
\text { earlier }\end{array}$ & 39.2 & 22.3 & $11.7(0.52)$ & $3.2(8)$ \\
\hline CIT. 3726 & $\begin{array}{l}\text { (now } \\
\text { preserved } \\
\text { at UCLA.) }\end{array}$ & 42.5 & 25.3 & $14.5(0.56)$ & $3.4(8)$ \\
\hline GSC. 5811 & $\begin{array}{l}\text { (Usher, } \\
1952 \text { ) }\end{array}$ & 47.0 & 27.2 & $14.1(0.52)$ & $2.8(6)$ \\
\hline $\begin{array}{l}\text { One from loc. } \\
\text { CAS. } 1467\end{array}$ & & - & c. 35.0 & $16.0(0.46)$ & - \\
\hline LSJU. 8605 & (immature) & 16.4 & 9.7 & $5.5(0.56)$ & $1.3(8)$ \\
\hline
\end{tabular}

Diagnosis.-The species is characterized by a thin shell, great involution,

* Measurements in this paper are in millimeters. 
very small umbilicus (less than 10 percent of the shell diameter), much compressed whorls, narrowly arched venter, rounded umbilical border, nearly parallel, rather than convergent, and only slightly convex flanks, thread-like, fine, narrow, and densely spaced subcostae, which incline moderately forward near the umbilicus, bend just below the mid-flank, run almost radially on the rest of the flanks, and again incline slightly forward near the venter, thus showing flexuosity. Near the umbilical half of the whorl can be seen the very faint, periodic constrictions, which give rise, on the surface of the shell, to low and narrow major ribs. The suture is very complicated, deeply and finely incised and has multipartite saddles, of which the phylloid terminals are indistinct. Minute phylloid terminals, however, are discernible, when the suture is not fully exposed but observed through the semi-transparent, inner layer of the shell.

Remarks.-Though its name is well known, the species is represented by relatively few specimens from the West Coast of America. The holotype is a small, probably immature, shell. UsHeR (1952) has described an additional specimen from the upper Lambert formation, which is much larger than the holotype.

In the Upper Cretaceous of Japan and Sakhalin there is a larger number of specimens, which I have briefly reported under the name of Neophylloceras compressum MATSUMото (1942). Comparing them with the American types, I have confirmed that they are nothing but the representatives of $N$. ramosum (MEEK) on the other side of the Pacific Ocean. Thus N. compressum Matsumoto is here suppressed as a synonym of $N$. ramosum (MEEK).

The specimens which have recently been described as the holotype and paratype of Phylloceras vaculae ANDERSON (1958) should undoubtedly be referred to the same species. I myself have obtained another example from the same locality (CIT. 1346) as ANDERSON's specimens. The "outline flare" of the umbilical wall which ANDERson (1958, p. 181) mentioned may correspond to what I (1942c, p. 675) called a spiral elevation at the umbilical margin. It may be feebly discernible in some specimens, but is never so distinct as in N. subramosum SPATH. In this and other respects I cannot find any distinction of specific importance between the holotypes of $N$. ramosum and " $P$. vaculae".

The specimen which was described as Phylloceras pachecoense ANDERson (1958, p. 182, pl. 53, fig. 1, 1a) is larger than, but otherwise very similar to, typical examples of Neophylloceras ramosum (MEEK). Its flanks are more flattened and more clearly parallel than is shown in ANDERson's sketch. There are, in addition to ANDERSON's illustrated specimen, more specimens in the same rock (CAS. 29108), that show inner whorls of smaller size; these are indistinguishable from unmistakable examples of $N$. ramosum (MEEK). Some of the Japanese examples of $N$. ramosum reach a moderate size; for instance, a specimen (GT. I-3506) from the Campanian zone of Inoceramus schmidti-Canadoceras kossmati is still septate at a diameter of $60 \mathrm{~mm}$., so that the complete shell with body chamber, if preserved, must exceed $100 \mathrm{~mm}$. in diameter. This size is intermediate between the holotypes of Neophylloceras ramosum (MEEK) and Phyllo- 
ceras pachecoense ANDERSON. However, the latter is still septate and, accordingly, unusually large. Many molluscan shells from the same bed as this specimen (the so-called Garzas bed) reach an unusually large size probably owing to some ecological environment.

The specimens from the Lower Cretaceous of California, which were referred to Ammonites ramosus by GABB (1864, p. 65, pl.11, fig. 12, 12a; pl. 12, fig. 12b), including his hypotypes (of 1864) in the Museum of Invertebrate Paleontology, University of California, Berkeley, and his homeotype in the Academy of Natural Science of Philadelphia (No. 12885), are mostly Hypophylloceras onoense (STANTON) (1895, p. 73) and partly another species of Hypophylloceras. They are clearly distinguished from the true Neophylloceras ramosum (MEEK) by their less complex sutures, with distinct phylloid terminals to the subdivided saddles (cf. Pl. 2, figs. 1 and 2).

Similarly the specimens from the Kennicott formation of Alaska, which were listed by Moffit (1938, table facing p. 80) as Phylloceras cf. ramosum, are not true $N$. ramosum (MEEK), but are $N$. cf. seresitense (PERVINQUIÈrE). IMLAY and REESIDE (1954, p. 234) have recorded the occurrence of $N$. ramosum (MEEK) in a formation overlying the Naknek formation at Cape Kaguyak, southwest Alaska. This is, I think, reliable, but I have had missed the opportunity of seeing the specimens.

I have not seen the specimens from the Quiriquina beds of Chile, but according to the description and figures of STEINMANN (1895, p. 80, pl. 5, fig. 4a, b; text-fig. 6), his "Phylloceras ramosum" does not seem to me to be identical with $N$. ramosum (MEEK), in that it has less flexuous subcostae, although they are doubtlessly allied to each other. Presumably it is close to Neophylloceras lambertense UsHeR (1952, p. 50, pl.1, figs.1-3). In fact, UsHeR put it in the synonymy of his species. This may be warrantable, but, without seeing the actual specimens, I hesitate to give a final conclusion.

Occurrence.-Localities TM. 2001=CIT. 1346, Member III of Popenoe in the Redding area, along with Subprionocyclus normalis (ANDERSON) ; LSJU. 2735, Upper Cretaceous of the Arroyo del Valle area, Tesla Quadrangle, along with Subprionocyclus normalis (ANDERSON); LSJU. 2006, lower part of the Funks formation or highest part of Sites formation, Rumsey Hills area; UCLA. 3642, basal part of the Chico formation in the type Chico area; LSJU. 2709, Enos Canyon, Yolo County (associated with Metaplacenticeras pacificum, etc.) ; CAS. 1467, 7 miles NW. of Winters (probably same as, or close to, LSJU. 2709), Yolo County (associated with Metaplacenticeras pacificum and Desmophyllites diphylloides) ; CAS. 31245, Arroyo del Valle, Bay Area (associated with Metaplacenticeras pacificum and Baculites inornatus) ; UC. A-7581, Reef Ridge, Kings County, in a shale unit probably equivalent to the relatively higher part of the Panoche group, associated with Baculites inornatus MEEK; probable examples from CAS. 29108, the so-called Garzas bed, probably belonging to the upper part of Panoche group, Merced County, west side San Joaquin Valley.

Thus the California examples, which I have referred to $N$. ramosum, came 
from various horizons between Upper Turonian and Upper Campanian. The occurrence in Japan proves the long stratigraphic range of this species, from Turonian to Upper Campanian.

According to UsHeR (1952) the species has been found in the Upper Lambert formation of Nanaimo group in British Columbia.

\section{Neophylloceras hetonaiense Matsumoto \\ Pl. 3, fig. 1a-d}

1942. Neophylloceras hetonaiense Matsumoto, Proc. Imp. Acad. Japan, vol.18, p. 675 , text-fig. $1 \mathrm{a}_{3}, \mathrm{~b}_{3}$.

1953. Neophylloceras hetonaiense, SPATH, Falkland Isl. Dep. Surv. Sci. Rep. no. 3 , p. 5 , pl. 1 , fig. 2 .

Types.-I established this species on several syntypes (Matsumoto, 1942). The lectotype, here designated, is GK. H3801a, from loc. H12b, bed IV b, Hetonai area, Hokkaido, the dimensions of which are shown below.

Material.-GK. H7002, GK. H7003, and another in LSJU from loc. TM. 204 (=LSJU. 3329) (Coll. M. B. PAYNe \& T. MATSUMOTO); two immature examples of the tuberculate variety from locs. CAS. 29656 (Coll. A. BENNIsON) and CAS. 31310 (Coll. C. C. CHURCH \& J. J. BRYON).

$\begin{array}{lccrrrr}\begin{array}{c}\text { Measurements.- } \\ \quad \text { Specimen }\end{array} & \text { Diameter } & \text { Height } & \text { Breadth (B/H) } & \text { Umbilicus }(\%) \\ \text { GK. H 7002 } & 55.0 & 33.1 & 18.5 & (0.56) & 3.0 & (5) \\ \text { GK. H 7003 } & - & 33.0 & 18.3 & (0.55) & 3.0 & \\ \text { GK. H 3801a (lectotype) } & 31.0 & 17.5 & 10.0 & (0.57) & 2.0 \quad(6)\end{array}$

Diagnosis.-This species is characterized, like Neophylloceras ramosum (MEEK), by great involution, very small umbilicus, much compressed whorls, and densely spaced, fine subcostae. The flank is evenly convex, with the maximum breadth of whorl at its middle, from where it inclines gradually towards umbilicus and also towards the narrowly arched venter. The subcostae incline slightly forward near the umbilicus, gradually change their curvature near the mid-flank and run almost radially on the main part of the whorl, showing less flexuosity than in $N$. ramosum (MEEK). On the inner half of the inner whorl blunt and short major ribs or bullae may develop, sometimes becoming strong enough to be called tubercles but sometimes very faint. The riblets correspond to the weak furrows on the mould. The suture is of nearly the same type as that of $N$. ramosum (MEEK).

Remarks.-The closest ally of the present species may be Neophylloceras lambertense UsHeR (1952, p. 50, pl.1, figs.1-3), the types of which came from the úpper part of the Lambert formation. Even such a detailed feature as the forward concavity of "a line touching the posterior ends of the auxiliary lobes" is common to both species. This might not be, however, so important for the specific classification of Neophylloceras. The distinctions are the much less flexuous subcostae and more flattened flanks of $N$. lambertense than $N$. hetonaiense. Although UsHeR mentioned shallow, radial depressions near the umbilicus 
of $N$. lambertense, no major ribs corresponding to them have been recognized in that species. The development of the bullae is variable in $N$. hetonaiense; and if developed, they are distinct on the inner whorl. They are discernible on the smaller specimens from locs. CAS. 29656 and CAS. 31310, but not distinctly discernible on the larger specimens from loc. TM. 204.

On examining the specimen from Graham Land, Antarctica, in the British Museum (Natural History) (BM. C. 41350), I agree with SPATH (1953) in referring it to this species.

Occurrence.-Locs. TM. 204 [=LSJU. 3329] and CAS. 31310, both of which in the type area of the Marca shale, Moreno formation; CAS. 29656, type locality of Gaudryceras aureum ANDERson, pebbly sandstone at the top of Panoche group (?), all west side of the San Joaquin Valley.

In Japan the species ranges from Campanian to Maestrichtian. The variety characterized by well defined radial bullae or subtubercles has been found in the Maestrichtian (Neohetonaian). A Santonian-Lower Campanian form, which I temporarily listed under $N$. aff. hetonaiense Matsumoto, can be distinguished from the present species.

The representative from Antarctica has been referred by SPATH to Upper Campanian.

I have seen an example of the present species (with umbilical bullae on the inner whorl) in the collection of Shell Oil Co. (J 400) from Kaguyak, Alaska Peninsula, associated with Pachydiscus n. sp. (the same as the one from the "Neohetonaian" [Maestrichtian] of Hokkaido) and several other species.

Family Desmoceratidae ZITTeL, 1895

Subfamily Desmoceratinae ZITTEL, 1895

Genus Desmoceras ZitTeL, 1884

Type-species.-Ammonites latidorsatus MiCHeLIN, 1838.

Synonym.-Latidorsella JACOB, 1908.

Generic diagnosis.-See SPATH, 1923 (Ammonoidea of the Gault) p. 39 and Matsumoto, 1954 (Cret. System Japan. Isl.), p. 248.

Remarks.-Genus Desmoceras includes subgenera Desmoceras (s.s.), D. (Lunatodorsella) BREISTROFFER, 1947, and D. (Pseudouhligella) MATsumoto, 1938. In California D. (Desmoceras) begins to occur in the Aptian, as represented by $D$. (D.) voyi ANDERson (1938, p. 180, pl. 40, figs. 4, 5). It is fairly common in the Middle Albian; the best example is $D$. (D.) merriami (ANDERSON) (1902, p. 103, pl. 6, figs. 135-138; 1938, p. 181, pl. 43, figs. 1, 2). D. kossmati MATSumoto, a Japanese species, has been confirmed to occur also in California, as described below. This is an example of $D$. (Desmoceras).

D. (Pseudouhligella) is represented in the West Coast region by $D .(P$. dawsoni WhITEAves. It occurs in the Upper Albian of British Columbia, California, Oregon, and Alaska (see Matsumoto, 1959a, p. 59-61). The Cenomanian species, D. (P.) japonicum YABE, is common in Japan, Sakhalin, and southern 
Alaska, but seems to be rare in California, because I have recognized only a comparable specimen in the collection of M. V. KIRK, from loc. SOC. K-206, on the Roaring River, Shasta County, associated with Sciponoceras sp. and Zelandites inflatus Matsumoto. I have seen $D$. (P.) poronaicum YABE in R. W. ImLAY's collection from loc. USGS. 26375, Grant County, Oregon. Desmoceras (Latidorsella) inane of ANDERSON (1958, p. 215, pl. 10, fig. 3, 3a) (non STOLICZKA, 1865), from loc. CAS. 31097, on Dry Creek, Tehama County, is better referred to $D$. (Pseudouhligella) poronaicum YABE. D. (P.) barryae ANDERSON (1958, p. 214, pl. 12, fig. 2, 2a) seems to occur in the Cenomanian.

\section{Desmoceras kossmati Matsumoto}

Pl. 2, fig. 2a-c; Text-fig. 1

1942. Desmoceras kossmati Matsumoto, Proc. Imp. Acad. Japan, vol. 18, p. 26, text-fig. 12.

1954 [1953]. Desmoceras kossmati, Matsumoto, Cret. System in the Japanese Islands, Appendix, p. 249, pl. 1 [17], figs. 1a, b, 2a, b, 3a, b, 4a, b, 5a, b, $6 \mathrm{a}, \mathrm{b} ; \mathrm{pl} .6$ [22], fig. 6 ; text-fig. 1 [47].

? 1865. Ammonites diphylloides, StoliczkA (non Forbes) (pro parte), Pal. Indica, ser. 3, vol. 1, p. 119, pl. 59, figs. 10, 11.

? 1898. Desmoceras n. sp. aff. inane, Kossmat (non Stoliczka), Beitr. Pal. Geol. Oesterr.-Ung. Or., vol. 11, p. 108 [173].

Lectotype.-GT. I-2551, from loc. N 507p, probable Lowest Cenomanian in South Sakhalin [Saghalien], described by Matsumoto (1954, p. 249) as holotype, but should have been called lectotype.

Material.-LSJU. 8581, an immature shell, with a fragmental piece of the body chamber, from loc. LSJU. 3337 (Coll. S. W. MULLER) ; several other comparable specimens from a locality (SC.-37) in Stony Creek, Fruto Quadrangle (S. Chuber \& T. Matsumoto). Comparable specimens from loc. SOC. K-190F (Coll. M. V. KIRK) and SOC. K-204 (Coll. M. V. KIRK).

\section{Measurements.-}

\begin{tabular}{|c|c|c|c|c|}
\hline Specimen & Diameter & Height & Breadth $(\mathrm{B} / \mathrm{H})$ & Umbilicus ( \\
\hline LSJU. & $\left\{\begin{array}{l}30.0 \\
20.0\end{array}\right.$ & $\begin{array}{r}\text { c. } 15.0 \\
10.5\end{array}$ & $\begin{aligned} c .16 .5 & (1.1) \\
11.0 & (1.05)\end{aligned}$ & $\begin{array}{r}c .5 .0 \\
2.6\end{array}$ \\
\hline
\end{tabular}

Descriptive remarks.-The Californian specimens before me are referred to Desmoceras kossmati Matsumoto because of the following diagnostic features. The shell is relatively small, much involute, and narrowly umbilicate. The whorl is slightly broader than high in the later growth-stages, but slightly higher than broad in the earlier growth-stages, except in the very early stage. The flank is convex, with the maximum breadth of the whorl at or slightly below the mid-flank; the venter is relatively narrowly rounded on the inner whorl but rather broadly rounded on the outer whorl; the umbilicus is narrow and the umbilical margin is rounded. The whorl is periodically constricted; the constriction is not much deeply marked, on some part fairly frequent but on some other parts infrequent, slightly flexuous on the flank and shows moderate projection on the venter. The 


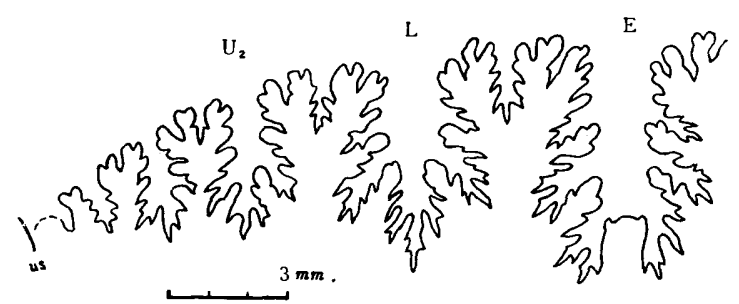

Fig. 1. Desmoceras kossmati Matsumoto. External suture, at whorl-height= $10 \mathrm{~mm}$., breadth $=10 \mathrm{~mm}$., of a specimen, LSJU. 8581, from loc. LSJU. 3337 , west of Coalinga, Fresno County.

suture is similar to that of Desmoceras latidorsatum (MICHELIN) (see JACOB, 1907, text-fig. 12 on p. 25 ; SALFELD, 1919, fig. 6 on p. 16 ; SPATH, 1923, text-fig. 9 on p. 40); but the stems and branches of lobes are narrow and deep, and the saddles are deeply incised (see Text-fig. 1 and also Matsumoto, 1954, text-fig. 1 [47]).

Occurrence.-Loc. LSJU. 3337, a canyon of Coalinga Hot Springs, a tributary of Walthan Creek, Priest Valley Quadrangle, Fresno County, west side of the San Joaquin Valley. The locality is in a shale unit (10 feet below a bentonite bed) slightly below a rudistid bearing conglomerate. This unit might belong to the Upper Albian, but in Japan the species is common in the Lower Cenomanian. Another locality, SC.-37, where comparable specimens were obtained, is in Stony Creek, Fruto Quadrangle, Glenn County, west side of the Sacramento Valley. This is again in a shale unit, below the conglomerate. From the same locality came Puzosia sp. and an ornate ammonite resembling Graysonites sp. A comparable specimen came from loc. SOC. K-190F, a tributary of the Roaring River, Ono Quadrangle, Shasta County, northwest side of the Sacramento Valley. KIRK obtained it along with Graysonites sp., which indicates the Lower Cenomanian. Another came from loc. SOC. K-204, close to the above locality on the bank of the Roaring River.

\section{Genus Desmophyllites Spath, 1929}

Type-species.-Desmoceras larteti SEUNES, 1891.

Synonym.-Schlüteria DE GRossouvRE, 1894.

Generic diagnosis.--See Matsumoto and OBAtA, 1955, p. 120.

Remarks.-Relationships of Desmophyllites with other allied or similar genera were discussed previously (MAтsumoto and ОватA, 1955, p. 120-121). There is no addition regarding the problem. Desmophyllites is widespread in the Campanian and also a part of the Maestrichtian. Many names were given to a widespread Indo-Pacific species, D. diphylloides (FORBES) by different authors, but they have to be synonymized. The same statement can be applied to the species from the West Coast. 


\section{Desmophyllites diphylloides (FORBES) \\ P1. 3, fig. 3a-c; Text-fig. 2}

1846. Ammonites diphylloides Forbes, Trans. Geol. Soc. London, ser. 2, vol. 7, p. 105 , pl. 8 , fig. $8 \mathrm{a}-\mathrm{c}$.

1865. Ammonites diphylloides, StoliczKA, Palaeontol. Indica, ser. 3, vol. 1, p. 119 , pl. 59 , figs. $8,8 \mathrm{a}, 9$.

1879. Ammonites selwynianus Whiteaves, Mesozoic Fossils, vol. 1, pt. 2, p. 104, pl. 13, fig. 1, 1a.

1898. Desmoceras diphylloides, Kossmat, Beitr. Pal. Geol. Oesterr.-Ungarns Or., vol. 11, p. 108 [173], pl. 19 [25], figs. 8a-c, 9a-c.

1903. Desmoceras selwynianum, WhiteaVes, Mesozoic Fossils, vol.1, pt.5, p. 351.

1907. Puzosia (Latidorsella) diphylloides, PERvinquièe, Etudes Pal. Tunisiénne, vol. 1, p. 140, pl. 6, figs. 1a, b, 2a, b, 7a-c.

1921. Desmoceras simplex van HoEPEN, Ann. Transvaal Museum, vol. 8, p. 19, pl. 3, figs. 11-16; text-fig. 10.

1921. Desmoceras crassum van HoEPen, Ann. Transvaal Museum, vol. 8, p. 20, pl. 4, figs. 3, 4 ; text-fig. 11 .

1931. Desmoceras diphylloides, BAsse, Monogr. Paléont. Crét. prov. Maintirano, Madagascar, p. 23, pl. 2, figs. 3, 4.

1931. Desmoceras (Latidorsella) diphylloides var. besairei Collignon, Ann. géol. Serv. Mines, fasc. 1, p. 15, pl. 2, figs. 8, 8a, 8b, 9; pl. 2, figs. 5-8.

1942. Schlüteria diphylloides, Matsumoto, Proc. Imp. Acad. Japan, vol. 18, p. 24.

1951. Desmoceras sp., Hertlein, Calif. State Div. Mine Bull. 154, pt. 4, p.191, fig. 2, no. 10.

1952. Schlüteria selwyniana, UsHer, Geol. Surv. Canada, Bull. 21, p. 63, pl. 5, figs. 3, 4; pl. 6, figs. 1-3; pl. 31, fig. 20.

1953. Desmophyllites diphylloides, SPATH, Falkland Islands Dependencies Surv., Sci. Rep., No. 3, p. 21 (footnote), pl. 2, fig. 5.

1955. Desmophyllites diphylloides, Matsumoto and OватA, Mem. Fac. Sci., Kyushu Univ., ser. D, vol. 5, no. 3, p. 121, pl. 24, figs. 1a, b, 2a, b, 3a, b, $4 \mathrm{a}, \mathrm{b}, 5 \mathrm{a}, \mathrm{b} ; \mathrm{pl} .30$, fig. 1 ; text-figs. $1,2$.

1958. Desmophyllites selwynianus, ANDERSon, Geol. Soc. Amer., Memoir 71, p. 215 , pl. 40 , fig. 2 .

1958. Desmophyllites siskiyouensis ANDERSON, Geol. Soc. Amer., Memoir 71, p. 215 , pl. 35, fig. 3, 3a; pl. 41, figs. 1-3, 3a.

1958. Desmophyllites yoloensis Anderson, Geol. Soc. Amer., Memoir 71, p. 216 , pl. 41 , fig. 6 .

Lectotype.-BM. C22682 from Valudayur, Pondicherry, India (see Matsuмото and OвATA, 1955, p. 122).

Material.-A considerable number of specimens from California and other parts of West Coast are referred to this species. Examples are as follows:

LSJU. 8583 (Pl. 3, fig. 3a-c; Text-fig. 2), from loc. LSJU. 2732 (Coll. L. W. FUNKHOUSER)

“LSJU. 37195” from Tesla Quadrangle, Alameda Co. (Coll. Stanford Geol. Surv.)

"LSJU. 31074" (A-C), Lost Hills Quad., Kern Co. (Coll. R. T. White)

Examples from loc. LSJU. 2709 (Coll. W. E. KENNETT \& Stanley McCoY)

Hypotype of Desmophyllites selwynianus of ANDERSON (1958, pl.40, fig. 2) 
from loc. CAS. 1552 (Coll. G. D. HANNA \& J. H. SHow)

Holotype and paratypes of Desmophyllites siskiyouensis ANDERSON (1958, pl. 41, figs. 1, 2, 3, 3a) from loc. CAS. 444 [=455] (Coll. F. M. ANDERson) and loc. CAS. 1552 (Coll. G. D. HANNA \& J. H. Show)

CAS. 9816, hypotype of HERTLEIN (1951)'s Desmoceras sp., equal to the holotype of yoloensis ANDERSON (1958, pl.41, fig. 6), from loc. CAS. 1467A (Coll. RAMBKE)

A specimen from loc. SOC. K-241 (no record of a collector)

In addition to the above, I have seen plastotypes of the lectotype and other examples of Schlïteria selwyniana. WHITEAVES from the Nanaimo group (UsHer, 1952).

\begin{tabular}{lccrrrr} 
Measurements.- & & & & & & \\
$\quad$ Specimen & Diameter & Height & \multicolumn{2}{c}{ Breadth (B/H) } & Umbilicus (\%) \\
LSJU. 8583 & 41.0 & 22.4 & 16.7 & $(0.75)$ & 3.5 & $(8.5)$ \\
LSJU. 31074 (A) & 26.0 & 15.0 & 11.2 & $(0.74)$ & 2.4 & $(9.2)$ \\
LSJU. 37195 & 21.8 & 12.0 & 9.2 & $(0.77)$ & 1.7 & $(7.8)$ \\
LSJU. no number & 22.2 & 12.0 & 9.6 & $(0.80)$ & 1.7 & $(7.6)$ \\
KELLEY 104 & 31.0 & 17.5 & 12.8 & $(0.73)$ & 2.8 & $(9.0)$
\end{tabular}

Descriptive remarks. - The specific diagnosis has recently been given on the occasion of the description of the desmoceratids from Hokkaido and Sakhalin [Saghalien] (MATSumoto and OватA, 1955, p. 123). The examples from the West Coast of North America well show the same characters and there is no need to alter the definition of the species.

On examining the ontogenetic change and variation of the shell form, MAtsumoto and ОватA $(1955$, p. 125) remarked that Ammonites selwynianus Whiteaves, Desmoceras simplex VAN HoEPEN, and Desmoceras crassum vaN HOEPEN are probably synonymous with Desmophyllites diphylloides (FoRBES). This is confirmed through the study of the specimens from California and other areas of West Coast, at least for Ammonites selwynianus WhitEAves. If the figures of the measurements are plotted on the diagram which MATSUMOTO and OватA (1955, p. 124, text-fig. 2) presented to demonstrate the proportion of whorl-height and breadth, they fall within the limit of the variation of Desmophyllites diphylloides (ForBes). The constrictions are about seven per whorl, being as frequent as in the examples of India and Japan. They are, likewise, prorsiradiate, slightly biconvex on the flanks, and strongly projected on the venter.

Although the septate whorl is uniformly arched on the venter, the adult body whorl sometimes shows a very low and broadly rounded elevation on the mid-venter. As the body chamber is often crushed, this feature is not always recognizable. The elevation is so blunt that can hardly be called a keel, but it does recall the keel of Damesites. The same character is observable on specimens from Hokkaido and Sakhalin, although it was previously regarded as a product of secondary deformation (see Matsumoto and OвAтA, 1955, pl. 24, fig. 1a, b).

The suture is similar to but is more complex and has more numerous auxiliary elements than that of Desmoceras. This character and stronger involution of the whorl are criteria to distinguish this species from such species as 


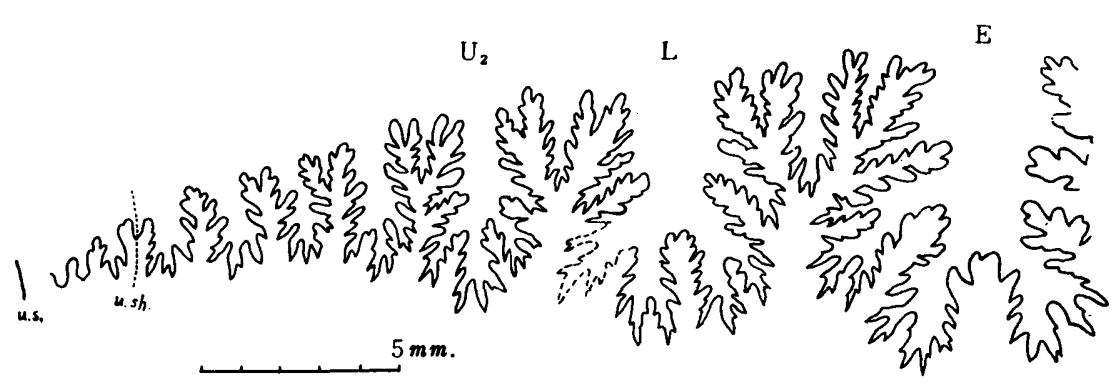

Fig. 2. Desmophyllites diphylloides (ForBEs). External suture of a Californian example, LSJU. 8583, from loc. LSJU. 2732, Arroyo del Valle, Alameda County.

Desmoceras (Pseudouhligella) dawsoni WHITEAVES of quite different geological age.

Occurrence.-Loc. LSJU. 2732, Arroyo del Valle, Tesla Quadrangle, Alameda County, Bay area, where this species is associated with Metaplacenticeras cf. pacificum (SмIтH). Loc. LSJU. 2709, SOC. K-241, and CAS. 1467A, all in Enos Canyon, probably an equivalent of the upper part of Forbes formation, Capay Quadrangle, Yolo County, west side Sacramento Valley; here again the species is associated with Metaplacenticeras pacificum (SMITH). Loc. CAS. 1552, north end of Shale Hills, and another locality in the shale unit, Kern County, southwest side of the San Joaquin Valley, where Tetragonites popetensis YABE and Baculites rex ANDERSON are associated. Loc. 104 of KELLEY in Joaquin Rock Quadrangle, upper part of Ragged Valley shale, west side San Joaquin Valley. Loc. CAS. 444 [455], near Henley, Siskiyou County, where the species is associated with Eupachydiscus haradai (JIMBO).

Desmophyllites diphylloides (FORBES) is thus common in California and occurs also in the Nanaimo group of British Columbia and in the equivalent beds in Sucia Island, Washington. The species is widespread in the Indo-Pacific region, as is indicated by its occurrence in Japan, Sakhalin, India, Madagascar, and South Africa (see Matsumoto and OBATA, 1955). Its geological range is relatively long, covering the whole of the Campanian (Infrahetonaian plus Paleohetonaian) in Japan; it may survive in the lower Maestrichtian of some areas.

\section{Genus Damesites Matsumoto, 1942}

Type-species.—Desmoceras damesi Јімво, 1894.

Remarks.-A generic diagnosis has already been given (see Matsumoto, 1942a, p. 25; 1954 in Matsumoto [Editor], 1954, p. 266). A nomenclatorial problem about the generic name was pointed out by WRIGHT and MATSUMoto (1954, p. 123) and a proposal has been submitted by WRIGHT (1957, p. 225) to ICZN.

Damesites is widespread in the Indo-Pacific region. CONLIN and CoBBaN told me (see SAITo and MATsumoto, 1956, p. 191) that probable representatives 
of it occur in the Gulf Coast-Western Interior region. The succession of species is best known in Japan and may be summarized as follows:

Damesites laticarinatus SAITo and MAtsumoto, 1956: Cenomanian

D. ainuanus MATsumoto, 1957: Turonian

D. damesi (Јімво) (1894): Coniacian-Lower Campanian

D. semicostatus Matsumoto, 1942: Coniacian-Lower Campanian

D. sugata (FORBES) (1846): Santonian-Campanian

D. hetonaiensis Matsumoto, 1942: Maestrichtian

In California and Oregon species of Damesites do not occur so abundantly as in Japan. Three new species were established by ANDERson (1958) under the generic name Kotoceras. Two of them are, in my opinion, identical and referable to one of the Japanese species. One more species, described by ANDERSON under a new generic and specific name can be included in another Japanese species.

\section{Damesites damesi intermedius MATSUMOTо \\ Text-figs. 3-5}

1927. Desmoceras (Kotôceras) damesi, YABE (non JimBo), Sci. Rep. Tohoku Imp. Univ., 2nd ser. vol.11, p. 44 [18], pl. 7 [5], fig. 9, 9a.

1954. Damesites damesi intermedia Matsumoto, Cret. System in the Japanese Islands, Appendix, p. 270, pl. 6 [22], fig. 4a, b.

1956. Damesites damesi intermedius, Matsumoto and Овата, Mem. Fac. Sci., Kyushu Univ., ser. D, vol. 5, p. 131, pl. 27, figs. 1, 2a, b.

1958. Kotôceras richardsoni Anderson, Geol. Soc. Amer., Memoir 71, p. 217, pl. 36, fig. 3, 3a.

1958. Kotôceras frazierense ANDERson, Geol. Soc. Amer., Memoir 71, p.217, pl. 40 , fig. 5, 5a.

Holotype of the subspecies.-GK. H3269, from loc. U513, bed Ur2, Upper Yezo group, Urakawa area, Hokkaido (MAтsumoto, 1954a, pl. 6 [22], fig. 4a, b) (see also Matsumoto and ОватA, 1956, pl. 27, fig. 2a, b).

Material.-Several Californian examples are before me, including ANDERson's 1958 originals :

A specimen which was designated as the holotype of "Kotôceras richardsoni" ANDERSON (1958, p. 217, pl. 36, fig. 3, 3a), from loc. CAS. 455A

A specimen, CIT. 3724, designated as the holotype of "Kotôceras frazierense"

ANDERSON (1958, p. 217, pl. 40, fig. 5, 5a), from loc. CIT. 1347, here

shown in Text-fig. 5 (Coll. W. P. Popenoe and W. A. Findlay)

CIT. 3476 (Text-fig. 3), from loc. CIT. 1034 (Coll. W. P. Popenoe and D. SCHARF)

Two specimens (one of them Text-fig. 4), from loc. UCLA. 3368 (Coll. James VALENTINE)

Measurements.-

$$
\text { Specimen }
$$

" $K$. richardsoni"

CIT. $3724^{*}$

$\begin{array}{cc}\text { Diameter } & \text { Height } \\ \text { c. } 50 & 26 \\ 86.5 & 49.3\end{array}$

Brea

22

$(0.84)$

Umbilicus (\%)

7

7 


\begin{tabular}{|c|c|c|c|c|}
\hline CIT. 3476 & c. 46 & 24.8 & $19.3 \quad(0.77)$ & 4.2 \\
\hline $\begin{array}{l}\text { One from loc. } \\
\text { UCLA. } 3368^{*}\end{array}$ & 一 & 34.8 & $23.7 \quad(0.68)$ & - \\
\hline $\begin{array}{l}\text { GK. H } 3269 \text { (body whorl } \\
\text { excluded) }\end{array}$ & 49.5 & 28.2 & $23.2 \quad(0.82)$ & 4.5 \\
\hline
\end{tabular}

Descriptive remarks. - The Californian specimens listed above have in common the characteristic features that the whorl is involute and moderately compressed with gently inflated flanks, that the umbilicus is small with a subrounded shoulder, that the ventral keel is elevated but has moderately broad base, without accompanying noticeable furrows, that the constrictions are roughly prorsiradiate, with only slight biconcavity on the flank, and remarkably projected on the venter, and that the surface is nearly smooth, except for very weak thread-like subcostae sometimes discernible on the outer whorl.

These characters conform with the diagnosis of Damesites damesi intermedius Matsumoto (1954, p. 270; Matsumoto and OватA, 1956, p. 131). Anderson was right in comparing one of his specimens (i.e. his "Kotôceras richardsoni") with the illustrated specimen of YABE (1927, pl. 7 [5], fig. 9, 9a), from Hokkaido. That Japanese specimen should be referred to $D$. damesi intermedius rather than to $D$. damesi damesi (JiмBo) (1894, p. 26, pl. 1 [17], figs. 2, 2a, 2b, 3; Matsumoto, 1954a, p. 267, pl. 5 [21], figs. 1a-d, 2a, b, 3a, b; text-figs. 10 [56], 11 [57]). The distinction which ANDERSON recognized between "Kotôceras richardsoni" and " $K$. frazierense" is a matter of preservation and also of individual variation. Actually the holotype of $K$. frazierense is secondarily crushed.

I have no comments on the small, presumably immature, specimens which were described as Kotôceras subsugatum ANDERson (1958, p. 217, pl. 35, fig. 2, 2a) [=Desmoceras sugatum, ANDERson, 1902, p. 98, pl. 3, figs. 98, 99], because all the specimens were lost in the San Francisco 1906 fire and because the specific diagnosis is not well expressed on the specimens of such small sizes.

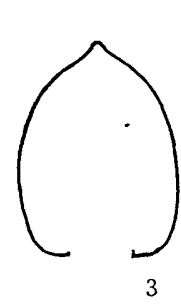

3

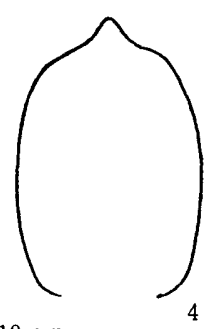

$10 \mathrm{~mm}$.

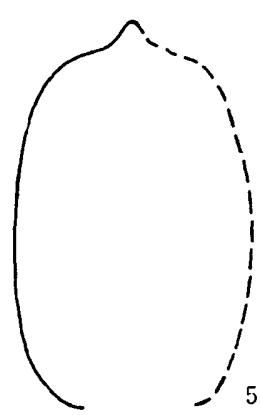

Figs. 3-5. Damesites damesi intermedius MATsumoto. Whorl-sections of three examples.

3. CIT. 3476, from loc. CIT. 1034, Oak Run, Member IV of the Redding area, Shasta County.

4. A specimen from loc. UCLA. 3368, Clover Creek, Member IV of the Redding area.

5. CIT. 3724, from loc. CIT. 1347, Roaring River, Ono Quadrangle, Shasta County. 
Occurrence.-Loc. CIT. 1347, which is, according to POPENOE (an answer to my inquiry), in the highest part of the Cretaceous beds exposed along the Roaring River, a tributary to Cottonwood Creek, Shasta County. It seems to be somewhat above the locality of Turonian ammonites. ANDERson recorded this locality as "Little Cow Creek", of the Redding area, which does not agree with POPENOE's information.

Loc. CIT. 1034, Member IV of the Redding area. At the same locality there are Peroniceras shastense ANDERson, Prionocycloceras sp., and Baculites schencki Matsumoto. The assemblage indicates the Coniacian.

Loc. UCLA. 3368, Member IV of the Redding area.

Loc. CAS. 455A, "Sidney RICHARDSON ranch, 4 miles north of Montague", Siskiyou County. The stratigraphic position of this locality is not precisely known, but among the associated species I identify Otoscaphites sp. and Inoceramus cf. uwajimensis YEHARA, which suggest the Coniacian. Other Lower Senonian ammonites are known at a nearby locality.

From these available records $D$. damesi intermedius seems to occur in the Coniacian of California. It is interesting to note that in the Japanese province $D$. damesi damesi occur more abundantly than $D$. damesi intermedius, persisting from the Coniacian to the Lower Campanian. I have already suggested (MATsUмото, 1957, p. 88) that $D$. damesi intermedius may represent an intermediate position from $D$. ainuanus MATsumoto of the Upper Turonian to D. damesi damesi and also to D. sugata (ForBes) of the Senonian.

\section{Damesites hetonaiensis fresnoensis (ANDERSON)}

1958. Neokotoceras fresnoense ANDERSON, Geol. Soc. Amer., Memoir 71, p. 218, pl. 57, figs. 1, 2, 3, 4, 5.

Holotype.-The specimen illustrated by ANDERson, 1958 pl. 57, figs. 1, 2, 5, as designated by ANDERSON. The type locality is CAS. 2362 [=CAS. 463].

Material.-In addition to the holotype and the illustrated paratypes, I have dealt with several other specimens, from locs. CAS. 2362, CAS. 2366, and CAS. 2368 (Coll. F. M. Anderson; J. A. TAFF, C. C. Church, C. M. Cross, \& G. D. HANNA; Max BinkHAUSER).

\begin{tabular}{|c|c|c|c|c|c|}
\hline Specimen & Diameter & Height & Breadtl & $(\mathrm{B} / \mathrm{H})$ & Umbilicus $(\%)$ \\
\hline Holotype of D.h.f. & 106 & 60.5 & 37.0 & $(0.61)$ & $7.9 \quad(7.4)$ \\
\hline $\begin{array}{l}\text { Paratype (ANDERSON, } \\
\text { pl. 57, f. } 3 \text { ) }\end{array}$ & $\begin{array}{l}164 \text { (body } \\
116.5\end{array}$ & $\begin{array}{l}\text { whorl) } \\
66.5\end{array}$ & 40.3 & $(0.60)$ & $9.0 \quad(7.7)$ \\
\hline 57, f. 4) ${ }^{(\prime \prime}$ pl. & 31.6 & 18.4 & 14.6 & $(0.79)$ & $1.8 \quad(5.7)$ \\
\hline Holotype of D.h.h. & 44.0 & 26.0 & 17.0 & $(0.65)$ & $3.3 \quad(7.5)$ \\
\hline
\end{tabular}

Descriptive remarks. - This form is characterized by a very involute shell, with a very narrow, crater-like umbilicus, relatively compressed whorls, a narrow and sharp, ventral keel which appear relatively early in growth-stage, very fine subcostae which show gentle sinuosity on the flank and are remarkably projected on the venter, weak constrictions which are only occasionally discernible on the 
outer whorl, and sutures similar to those of Damesites damesi, with very finely and deeply incised elements.

In all the above characters it can be specifically included in Damesites hetonaiensis Matsumoto (1954a, p. 271, pl. 6 [22], figs. 1a-c, 2a, b, 3a, b; text-fig. 12 [58]). The only distinction that can be considered in our present knowledge is that the Californian form is represented by the specimens of moderately large size (diameters being $100-200 \mathrm{~mm}$. in the adult body whorl), on which the subcostae are fine but distinct, while the Japanese one, so far as I know, by those of relatively small size (below $100 \mathrm{~mm}$. in diameter), on which the subcostae are very fine and sometimes indistinct. This might be merely a difference in growth-stages. In fact the immature specimens of California are indistinguishable from the Japanese type specimens. It is rather difficult to decide whether the Japanese specimens are still immature or already mature at that small size, although some of them have crushed body whorls. There may be also some difference in geological age between the Californian and Japanese forms. For the time being the two forms are separated subspecifically as follows:

Damesites hetonaiensis hetonaiensis, characterized by a relatively small size and very faint subcostae

Damesites hetonaiensis fresnoensis, characterized by a relatively large size and fine but fairly distinct subcostae

ANDERSON (1958, p. 218) established a new genus, Neokotôceras, for this Californian form, but its separation from Damesites is not warrantable. He mentioned the absence of the constriction on the adult whorl, but actually it is occasionally found, as a photograph (ANDERson, 1958, pl. 57, fig. 3) clearly indicates. Size was considered by him a criterion, but there are some examples of Damesites semicostatus MATsumoto, which attain fairly large size (see MATSUмото and ОватA, 1956, pl. 26, fig. 2a, b; pl. 30, fig. 6). The suture is not of Puzosia type but of Desmoceras type, being similar to that of $D$. damesi or $D$. semicostatus. Its external saddle is not tripartite but bipartite, although somewhat assymmetric. Thus the differences from the already known species of Damesites are not more than specific. Therefore Neokotôceras should be suppressed as a subjective synonym of Damesites.

Among the hitherto described species, D. semicostatus is the closest ally of $D$. hetonaiensis, but the latter has a smaller keel, somewhat more compressed whorls, finer and less flexuous subcostae, less frequent constrictions, and more finely incised sutures than the former. D. hetonaiensis fresnoensis may represent an intermediate stage between $D$. semicostatus and $D$. hetonaiensis hetonaiensis.

Occurrence.-Locs. CAS. 2362, CAS. 2366, and CAS. 2368, "Ragged Valley shale" or "Pachydiscus silt" in the northern part of Coalinga Quadrangle, Fresno County, west side of the San Joaquin Valley. Among the associated species there are Pachydiscus egertoni (FORBES), Anagaudryceras mikobokense CoLlignon, and Gaudryceras (Vertebrites) kayei (FoRBES). The suggested age is the Lower Maestrichtian or the highest part of the Campanian. 


\section{Subfamily Puzosiinae Spath, 1922 \\ Genus Puzosia BAYLe, 1878}

Type-species.-Ammonites subplanulatus ScHLÜter, 1871.

Generic diagnosis.-See Matsumoto, 1954b (Mem. Fac. Sci., Kyushu Univ., ser. D, vol. 5), p. 70 .

\section{Puzosia intermedia Kossmat}

1898. Puzosia gaudama var. intermedia Kossmat, Beitr. Pal. Geol. Oesterr.Ungarns Or., p. 116 [181], pl. 17 [23], fig. 3a-c.

1954. Puzosia orientale (recte orientalis) Matsumoto. Mem. Fac. Sci., Kyushu Univ., Ser D, vol. 5, p. 74.

Holotype.-The single, illustrated specimen of Kossmat (1898, pl. 17 [23], fig. 3a-c), from the Lower Trichinopoly group of India.

Diagnosis.-A species of Puzosia characterized by relatively compressed whorls, a narrowly arched venter, and numerous, relatively fine ribs which are remarkably projected on the venter, prorsiradiate on the sides. On the inner half of the flanks the ribs are more or less weakened or almost obsolete.

Remarks.-Because Puzosia orientalis Matsumoto, 1954 and P. gaudama var. intermedia Kossmat, 1898 are specifically identical, the specific name must be Puzosia intermedia Kossmat, 1898. The subspecies which I distinguished in my 1954 paper should be called $P$. intermedia intermedia Kossmat, $P$. intermedia orientalis Matsumoto, and $P$. intermedia kossmati Matsumoto. I have recognized the second subspecies in the Upper Cretaceous of California.

\section{Puzosia intermedia orientalis Matsumoto Pl. 4, fig. 1a-c}

1954. Puzosia orientale (recte orientalis) Matsumoto, Mem. Fac. Sci., Kyushu Univ., ser. D, vol. 5, p. 74, pl. 13, figs. 1, 2a, b.

Holotype of the subspecies.-GK. H1225 from the Lower Turonian of Hokkaido, Japan.

Material.-Relatively well preserved specimen, UC. 36438 (P1.4, fig. 1a-c), from loc. K-210, and another from loc. K-211 (both Shell Oil Co., Coll. M. V. KIRK); a crushed but identifiable specimen from loc. CAS. 33703.

Measurements.-

\begin{tabular}{lccccccc} 
Specimen & Remarks & Diameter & Height & Breadth $(\mathrm{B} / \mathrm{H})$ & \multicolumn{2}{c}{ Umbilicus (\%) } \\
UC. 36438 & & 175.0 & 76.0 & 61.0 & $(0.80)$ & 49.0 & $(28)$ \\
$\quad$ "I & $1 / 2$ vol. earlier & - & 50.0 & 40.5 & $(0.81)$ & - & \\
GK. H1225 (after MATSUMOTO, & 126.3 & 50.0 & 38.7 & $(0.78)$ & 43.3 & $(34)$
\end{tabular}

Descriptive remarks.-The Californian specimens before me can be identified with $P$. intermedia orientalis MATsumoto by their compressed whorl, fine and numerous subcostae, that are quite obsolete on the inner half of the whorl and show prominent forward bend on the ventral part. The illustrated specimen shows five to six constrictions per whorl; the constrictions are slightly prorsiradi- 
ate and gently arcuate on the flank and show prominent projection on the venter in parallel with the subcostae. It also exhibits the sutures of typical Puzosia type; finely and deeply incised elements, a large and asymmetrically trifid L, which is much deeper than $\mathrm{E}$, oblique $\mathrm{U}_{2}$, and remarkably descending auxiliaries (i.e. subdivisions of $\mathrm{U}_{3}[=\mathrm{S}]$ ).

This specimen is slightly broader than the Japanese holotype, but the holotype itself has slightly broader and slightly more inflated outer whorl than the measured part of the shell of middle growth-stage. Therefore the slight difference can be ignored as variation within the subspecies. The specimen has the last suture near its anterior end, and the preserved portion of the body chamber is crushed.

I have separated subspecifically the examples from India and Portugal as Puzosia intermedia kossmati Matsumoto (1954, p. 75). The Californian example is closer to the typical form of Japan than to that Indo-Mediterranean subspecies.

In addition to the above listed specimens, there is another that came from loc. LSJU. 3194 (Coll. S. W. MULLER \& MARSH). It is poorly preserved, but its mode of ribbing suggests $P$. intermedia intermedia Kossmat $[=P$. gaudama var. intermedia Kossmat, 1898, p. 116 [181], pl. 17 [23], fig. 3a-c] (Matsumoto, 1954b, p. 76, pl. 12, figs. 2, 3).

Occurrence.-The best example came from loc. SOC. K-210, and another comparable one from loc. SOC. K-211, both in the Roaring River, Ono Quadrangle, northwest side of the Sacramento Valley. The localities are close to loc. SOC. K-209 where Kanabiceras septemseriatum (CRAGIN) and Plesiovascoceras cf. californicum (ANDERSON) have been obtained. K-211 has another specimen which is referable to Mammites sp. Therefore the above two examples certainly came from the Lower Turonian. The Japanese types also came from the Lower Turonian.

The locality CAS. 33703, Dry Creek, Ono Quadrangle, where Puzosia cf. intermedia orientalis was found associated with Scalarites sp., is stratigraphically below the locality of Subprionocyclus sp.

The locality LSJU. 3194 of the Coalinga area, west side of the San Joaquin Valley, where $P$. cf. intermedia intermedia was obtained, has not yet been stratigraphically well settled. However, in the Los Gatos Creek, NE. 1/4 of SE. 1/4 sec. 34, T. 19S., R.13E., which is not far from, but presumably somewhat lower than, this locality, an ammonite was obtained by W. N. BARBAT, which is referable to Plesiovascoceras sp.

Genus Mesopuzosia Matsumoto, 1954

Type-species.-Mesopuzosia pacifica Matsumoto, 1954.

Generic diagnosis.-See Matsumoto, 1954b (Mem. Fac. Sci., Kyushu Univ., ser. D, vol. 5), p. 79 ; also WRIGHT in MOORE [Editor] 1957, p. L 367. The distinction from Parapuzosia has been already mentioned.

Remarks.-Species of Mesopuzosia occur fairly commonly in the Turonian 
and Lower Senonian of Hokkaido and Sakhalin, but they are only occasionally found in the Upper Cretaceous of California. The species which I have recognized are as follows:

(1) Mesopuzosia pacifica Matsumoto

(2) M. indopacifica (Kossmat)

(3) M. cf. densicostata Matsumoto

The last species is represented by an imperfectly preserved specimen from loc. UCLA. 3623 on Chico Creek, lower part of the Chico formation (Coll. L. E. \& R. B. SAUL), east side of the Sacramento Valley. The first two are described below.

\section{Mesopuzosia pacifica MATSUMoto \\ Pl. 6, fig. 2; Text-fig. 6}

1954. Mesopuzosia pacifica Matsumoto, Mem. Fac. Sci., Kyushu Univ., ser. D, vol. 5, p. 82, pl. 14, fig. 1a, b; pl. 15, figs. 1a, b, 2a, b; pl.16, figs. 1a, b, $2 \mathrm{a}, \mathrm{b}, 3 \mathrm{a}, \mathrm{b}$; text-fig. 2.

1958. Puzosia (Parapuzosia) klamathonae ANderson Geol. Soc. Amer., Memoir 71, p. 237, pl. 5, fig. 1, 1a.

Holotype.-GK. H 1257 (Matsumoto, 1954b, pl. 15, fig. 1a, b, c), from loc. Y $216 \mathrm{p}$, Saku formation (Turonian), Shiyubari Valley, Ishikari Province, Hokkaido.

Material.-The specimen which was designated as the holotype of Puzosia (Parapuzosia) klamathonae ANDERSON (1958, pl. 5, fig. 1, 1a) (Text-fig. 6 in this paper), from "Roaring River, Shasta County." Anderson's another example, from loc. CAS. 1293A, Redding area. GK. H 7029 (Pl. 6, fig. 2), from loc. TM. 2002 [=LSJU. 3289], Redding area (Coll. W. P. Popenoe and T. Matsumoto). The specimen of Oregon which ANDERson mentioned under $P$. $(P$.) klamathonae was not at my disposal.

$\begin{array}{lccrr}\begin{array}{l}\text { Measurements.- } \\ \quad \text { Specimen }\end{array} & \text { Diameter } & \text { Height } & \text { Breadth (B/H) } & \text { Umbilicus (\%) } \\ \text { Holotype (GK. H1257) } & 101.8 & 40.4 & 33.6(0.83) & 33.2(32.6) \\ \text { Holotype of } P .(P .) & 91.0 & 37.1 & 26.8(0.72) & 29.3(32.2) \\ \text { klamathonae } & 53.3 & 22.3 & 17.0(0.76) & 18.3(34.3) \\ \text { GK. H 7029 } & \end{array}$

Descriptive remarks.-The Californian specimens under consideration quite resemble the holotype and paratypes of Mesopuzosia pacifica Maтsuмото (1954b, p. 82, pl. 14, figs. 1a, b, 2a, b; pl. 16, figs. 1a, b, 2a, b, 3a, b; text-fig. 2) in the moderate size of umbilicus, the slightly convex flanks, the subelliptical whorl section, the moderately strong ribs which have a gently sigmoidal curvature on the flank, gradually becoming moderately projected on the venter, and the details of sutures. The only small difference is that the whorl of the Californian form is slightly more compressed on average than that of the Japanese one (see measurements). The proportion between breadth and height of the whorl $[B / H$ in my measurements] is, in fact, variable even in the Japanese specimens, ranging from 0.77 to 0.84 in the middle or adult stage (see Matsumoto, 1954b, p. 82, 83). 


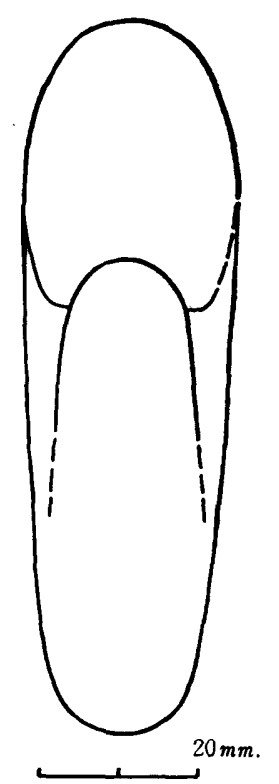

Fig. 6. Mesopuzosia pacifica Matsumoto. Outline of the frontal view of a Californian example [=holotype of Puzosia (Parapuzosia) klamathonae ANDERSON].

It is, in the two, measured Californian specimens, smaller than these figures but the difference is slight.

I have mentioned that in the Japanese specimens there are a few which have somewhat more compressed whorls than the normal ones. They are very close to, if not quite identical with, the Californian specimens under consideration. If ample material could be accumulated, the relatively compressed form of California might be subspecifically separated from the Japanese one. This might be a geographical subspecies or it could be a passage form from typical $M$. pacifica to $M$. indopacifica. Anyhow, I should regard the Californian form as being specifically identical with $M$. pacifica MAtsumoto. The ANDERson's name, klamathonae, could be used as the subspecific name, if the subspecific subdivision were justified.

Occurrence.-The locality of the ANDERSON's specimen is recorded as being "on Roaring River, Shasta County, not far above the Thompson ranch house, and 1.5 miles east of the basal conglomerate of the Upper Cretaceous, within the Turonian." Other specimens are more precisely located: loc. CAS. 1293A, 1 mile north of Frazier Corner, Redding area, probably in Member II of Popenoe; loc. TM. 2002 [=LSJU. 3289], Swede Creek, Redding area. From the last locality Romaniceras aff. pseudodeverianum (JIMBO) was obtained.

\section{Mesopuzosia indopacifica (Kossmat)}

1898. Puzosia indopacifica Kossmat, Beitr. Pal. Geol. Oesterr.-Ungarns Or., 
vol. 11, p. 117 [132], pl. 17 [23], fig. 2a, b; pl. 18 [24], fig. 3.

1932. Puzosia (Parapuzosia) indopacifica, Collignon, Ann. Pal., vol. 21, p. 18, pl. 6, fig. 1, 1a, $1 \mathrm{~b}$.

1954. Mesopuzosia indopacifica, Matsumoto, Mem. Fac. Sci., Kyushu Univ., ser. D, vol. 5, p. 84.

1958. Puzosia (Parapuzosia) hearni Anderson, 1958, Geol. Soc. Amer., Memoir 71 , p. 238, pl. 38, fig. 1, 1a, 1 b.

Holotype.-The illustrated and measured specimen of Kossmat (1898, p. 117 [182], pl. 17 [23], fig. 2a, b; pl. 18 [24], fig. 3), who established this species on a single specimen, as indicated in his description.

Material.-The Californian examples to be described here are the specimen which was designated as the holotype of Puzosia (Parapuzosia) hearni ANDERson (1958, p. 238, pl. 38, fig. 1, 1a, 1b) (CAS. Type Coll., donated by Miss Minnie HEARN), from Yreka area, Siskiyou County, and several others, less perfectly preserved than ANDERSON's, from loc. CAS. 31101 (Collector unrecorded), and loc. SOC. K-212 (Coll. M. V. KIRK).

Measurements.-

\begin{tabular}{lclcccc}
\multicolumn{1}{c}{ Specimen } & Diameter & Height & \multicolumn{2}{c}{ Breadth (B/H) } & \multicolumn{2}{c}{ Umbilicus (\%) } \\
Holotype (Kossmat, 1898) & 115 & 44.5 & 33 & $(0.74)$ & 41 & $(36)$ \\
ColLIGNON, 1932 & 184 & 80 & 60 & $(0.75)$ & 50 & $(27)$ \\
GK. H 1248a (MATSUMOTo, & 100 & 36.5 & 26.5 & $(0.73)$ & $32.5+(32.5+)$ \\
1954b) & & 36 & 27 & $(0.75)$ & 27 & $(30)$ \\
$P .(P$.$) hearni ANDERSON$ & 90 & 36 &
\end{tabular}

Descriptive remarks. - The Californian specimens under consideration are identical with Mesopuzosia indopacifica (Kossmat) (see above list) by the moderate width of umbilicus, the relatively compressed whorl, the numerous ribs which are prorsiradiate and only slightly flexuous on the main part of the flank and remarkably projected on the venter.

The ribs of ANDERSON's specimen are finer than those of the Indian holotype (Kossmat, 1898, pl. 17 [23], fig. 2a, b) but are as fine as those of the illustrated specimen of CollignoN (1932, pl. 6, fig. 1, 1a, 1b), from Madagascar. Judging from the Japanese examples as well as the Indian holotype, the ribs become gradually coarser on the outer, probably adult, whorl. The relatively coarse, adult type ribs do not always appear at the same diameter of the shell.

Occurrence.-The original locality of HEARN's specimen is recorded by ANDERSON (1958, p. 230) as "on the old Hagerdorn ranch, 8 miles northeast of Yreka, Siskiyou County, in the upper part of the Turonian." For other specimens, loc. CAS. 31101, on Dry Creek, Tehama County, northwest side of the Sacramento Valley, together with Subprionocyclus sp.; loc. SOC. K-212, on the bank of the Roaring River, Shasta County, northwest side of the Sacramento Valley, again associated with Subprionocyclus sp.

The holotype came from the Upper Trichinopoly group of India. The Japanese examples occur in the Turonian Saku formation of Hokkaido.

\section{Genus Jimboiceras Matsumoto, 1954}

Type-species.-Desmoceras planulatiforme Јімво, 1894. 
Synonym.-Eocanadoceras ANDERSON, 1958.

Remarks.-Jimboiceras SHImizu, 1935 is invalid, because it was not proposed in accordant with the Rules of Zoological Nomenclature. The generic name was validated by MATSUMoTo, 1954, when a full generic diagnosis was given and the relations with other genera were discussed.

While Jimboiceras occurs fairly commonly in the Turonian and Lower Senonian of Japan and Sakhalin, it is represented, as far as I know, by only a few incomplete examples in California.

\section{Jimboiceras cf. planulatiforme (JIMBO)}

Synonym.-

1958. Puzosia (Eocanadoceras) hannai Anderson, Geol. Soc. Amer., Memoir 71, p. 239 , pl. 30 , fig. $6,6 \mathrm{a}, 6 \mathrm{~b}, 6 \mathrm{c}$.

Compare.-

1894. Desmoceras planulatiforme JiмBo, Pal. Abh., Bd. 6 [N. F., Bd. 2], p. 27 [173], pl. 1 [17], fig. 4, 4a:

1954. Jimboiceras planulatiforme, Matsumoto, Mem. Fac. Sci., Kyushu Univ., ser. D, vol. 5, p. 96 , pl. 20, figs. 1, 2, 3a-c, 4 .

Lectotype of $J$. planulatiforme (JIMBO).-GT. I-94, the illustrated specimen of Jiмвo (1894, pl. 1 [17], fig. 4, 4a), from the Obirashibets, Hokkaido. The indication of this specimen as holotype in my previous paper (1954b, p. 97, pl. 20, fig. 1) was incorrect, because Јімво established the species on several syntypes.

Material.-The holotype of Puzosia (Eocanadoceras) hannai ANDERSON (1958, pl. 30, fig. 6, 6a, 6b, 6c), from loc. CAS. 2245 (Coll. J. A. TAFF and C. M. Cross). In addition to it there are a few, poorly preserved specimens, from locs. CIT. 1532 and CIT. 1533, which can possibly be referred to Jimboiceras.

Descriptive remarks.-The small inner whorl of the Californian specimen is "Puzosia-like", as ANDERSON (1958, p. 239) correctly stated, but is rather rounded in cross section, being closer to Puzosia (Anapuzosia) than to Puzosia (s.s.). The outer whorl has somewhat inflated flanks, but is still higher than broad and has a vertical umbilical wall as in many genera of the Puzosiinae. The suture was described by ANDERSON as "Canadoceras-like", but actually it is more similar to that of Jimboiceras planulatiforme (see MATsumoтo, 1954b, pl. 20, fig. 1), being of Puzosia type. The ribs are relatively coarse as compared with those of normal Puzosia, nearly rectiradiate on the inner two thirds of the flank, gradually passing to a ventral projection on the remaining outer part, where secondary ribs are intercalated or branch from the primaries. The wide, deep constrictions follow the curvature of the ribs.

From all these characters the specimen under consideration is probably referable to Jimboiceras planulatiforme (JIMBO) (see above list). ANDERSON mentioned the slight swellings on the umbilical border of the longer ribs. The swelling, which is not always discernible, is merely a slight angulation of the rib at the subangular umbilical shoulder and cannot be regarded as a tubercle of the type that is seen in Pachydiscidae. Such a slight angulation is also discern- 
ible on some of the major ribs of the Japanese specimens of Jimboiceras.

Summarizing the above, Puzosia (Eocanadoceras) hannai ANDERson, 1958 is very probably a synonym of Jimboiceras planulatiforme (JIMBo, 1894). $P$. $(E$.$) hannai was designated as the type-species of subgenus Eocanadoceras$ ANDERSON, 1958, while J. planulatiforme is the type-species of Jimboiceras MATSUmoto, 1954. Accordingly Eocanadoceras is unnecessary, falling in the synonymy of Jimboiceras.

Occurrence.-Loc. CAS. 2245 [=CAS. 28179] on Dry Creek, Tehama County, California. The available evidence suggests that this is probably Turonian.

Other comparable specimens from locs. CIT. 1532 and CIT. 1533, near the top of Member II (Turonian), Redding area, Shasta County, California.

In Japan and Sakhalin J. planulatiforme is characteristic of the Neogyliakian, approximately Turonian.

\section{Genus Pachydesmoceras Spath, 1922}

Type-species.-Ammonites denisonianus StoliczKA, 1865.

Remarks.-The generic diagnosis and the relation to other genera were given on a previous occasion (MAтSUмото, 1954b, p. 99). In Japan and Sakhalin the following two species have been reported:

P. cf. denisonianum (StoliczKa) (Upper Albian and Cenomanian)

$P$. pachydiscoide Matsumoto (Turonian)

In California I have recognized the following two species:

$P$. colusaense (ANDERSON) (probably Upper Albian)

$P$. pachydiscoide Matsumoto (Turonian)

I have already given short remarks on the first species in connection with an Alaskan example of Pachydesmoceras (MATSumoto, 1959a, p. 62).

\section{Pachydesmoceras pachydiscoide Matsumoto \\ Text-fig. 7}

1954. Pachydesmoceras pachydiscoides [recte pachydiscoide] Matsumoto, Mem. Fac. Sci., Kyushu Univ., ser. D, vol. 5, p. 101, pl. 9, figs. 2a, b.

1958. Pachydiscus rosewoodensis AnDERson, Geol. Soc. Amer., Memoir 71, p. 222, pl. 31, fig. 1.

Holotype.-GT. I-2805, from the Miho group, Naibuchi valley, South Sakhalin (MAтsumoto, 1954b, pl. 9, figs. 2a, b).

Material.-While there are numerous specimens of this species in Hokkaido and Sakhalin, only one well preserved example from California is at my disposal. That is the holotype of Pachydiscus rosewoodensis ANDERson (1958, p. 222, pl. 31, fig. 1) (Text-fig. 7 in this paper), from loc. CAS. 31102.

Measurements.-

\begin{tabular}{lcccccc}
$\quad$ Specimen & Diameter & Height & Breadth (B/H) & \multicolumn{2}{c}{ Umbilicus (\%) } \\
"rosewoodensis" & 143.5 & 59.5 & c. $24 \times 2(0.8)$ & c. $46(32)$ \\
GT. I-2805 & 215 & 98 & 84 & $(0.86)$ & $65(30)$
\end{tabular}




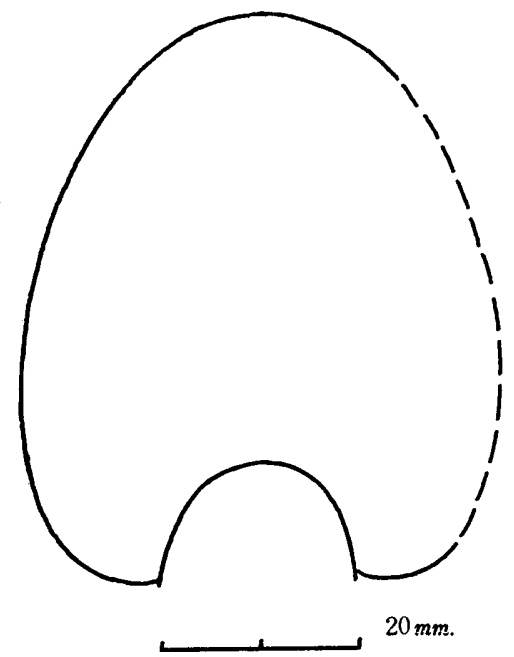

Fig. 7. Pachydesmoceras pachydiscoide MATsumoto. Whorl-section of a Californian example [=holotype of Pachydiscus rosewoodensis ANDERsoN], from loc. CAS. 31102, Dry Creek, Tehama County.

Descriptive remarks.-The Californian specimen under consideration is wholy septate and has an impression of at least one more outer whorl. Therefore it is regarded as representing the inner whorls of a large shell. Its whorl is higher than broad, gently inflated on the flanks, and broadest in the lower part.

The ribs on the main part are gently arcuate, projected and not sinuous. On the main part they are fairly crowded and alternately long and short, but on the last part of the preserved whorl, they gradually become distant and of nearly equal length. This evidently foreshadows the distant and equally long ribs to be developed on the adult whorl. The periodic constrictions and the accompanying elevation are parallel to the long ribs. Unlike Pachydiscus there is no tubercle.

The suture is of Puzosia type rather than Pachydiscus type.

In all the above characters the Californian specimen conforms with Pachydesmoceras pachydiscoide MAтsumoto (1954b, p. 101, pl. 9, figs. 2a, b), from Hokkaido and Sakhalin, and specific identity is undoubted. Consequently Pachydiscus rosewoodensis ANDERson, 1958 falls in the synonymy of Pachydesmoceras pachydiscoide MATSUmoto, 1954.

Occurrence.-Loc. CAS. 31102, "1 mile northwest of Rosewood, on Dry Creek", Tehama County. The locality is not far from the locality of Subprionocyclus sp., being in the relatively higher part of the Cretaceous section along the creek. LOC. SOC. K-213, Roaring River, Shasta County (a comparable specimen).

In Japan the species occurs in the Turonian. 
Subfamily Hauericeratinae MAтsumото, 1938

Genus Hauericeras DE GRossouvre, 1894

Subgenus Gardeniceras Matsumoto and Oвata, 1956

Type-species (of the subgenus).-Ammonites gardeni BaILY, 1855.

The subgeneric diagnosis and the distinction from Hauericeras (Hauericeras) have already been given by Matsumoto and ОватA (1956, p. 133-135). In spite of a recent suppression of Gardeniceras (see MOORE [Editor], 1957, p. L371), I still keep it as a subgenus of Hauericeras, because it represents a natural subgroup and is taxonomically (and also stratigraphically) useful.

\section{Hauericeras (Gardeniceras) angustum Y $\mathrm{ABE}$ \\ Pl. 4, fig. 4a-c}

1865. Ammonites gardeni, Stoliczka (non BaILy), Mem. Geol. Surv. India, Pal. Indica, ser. 3, vol. 1, p. 61, pl. 28, fig. 4 .

1890. Desmoceras gardeni, Yoкочама, Palaeontographica, vol. 36, p. 184, pl. 20, fig. 10.

1898. Desmoceras (Hauericeras) gardeni, Kossmat, Beitr. Pal. Geol. Oesterr.Ungarns Or., vol. 11, p. 123, pl.18, figs. 7a, b, 8, 10.

1904. Hauericeras gardeni, YABE, Jour. Coll. Sci., Imp. Univ. Tokyo, vol. 18, p. 32.

1904. Hauericeras angustum YABE, Jour. Coll. Sci., Imp. Univ. Tokyo, vol.18, p. 33, pl. 5, figs. 5,6 .

1952. Hauericeras gardeni, Usher, Geol. Surv. Canada, Bull. 21, p.61, pl. 5, figs. 1, 2.

1956. Hauericeras (Gardeniceras) angustum, Матsumoto and Овата, Mem. Fac. Sci., Kyushu Univ., ser. D, vol. 5, p.137, pl. 24, fig. 6; pl.28, figs. 1a, b, 2; pl. 29, fig. 1a, b, 2a, b, 3a, b, 4a, b, 5; text-figs. 5, 7 .

1958. Hauericeras mickeyi ANDERson, Geol. Soc. Amer., Memoir 71, p. 219, pl. 47 , fig. 2, 2 a.

Holotype.-GT. I-259, from the Upper Yezo group in the Urakawa area, Hokkaido, as originally designated by YABE (1904, pl. 5, figs. 5, 6) (see also MAтsumoto and Овата, 1956, pl. 29, fig. 2a, b).

Material.-I refer the following specimens to this species:

"Holotype of Hauericeras mickeyi ANDERSon (1958, p. 219, pl. 47, fig. 2, 2a), from loc. CAS. 27835, Chico Creek (Coll. J. A. TAFF, G. D. HANnA, and C. M. CRoss)

UCLA. 28826 (Pl. 4, fig. 4a-c) [=CIT. 3474], from loc. CIT. 1017, Chico Creek (Coll. W. P. Popenoe and D. W. Scharf)

CIT. 3730 (now preserved at UCLA), from loc. CIT. 1226, Chico Creek (Coll. W. P. Popenoe)

UCLA. 28824 and UCLA. 28825, from loc. UCLA. 3633, Chico Creek (Coll. L. E. \& R. B. SAUL)

They are fairly well preserved, although they are still immature. There are fragmentary specimens, from loc. UCLA. 3623 and UCLA. 3627, which are comparable with the present species. 
Measurements.-

\begin{tabular}{|c|c|c|c|c|}
\hline Specimen & Diameter & Height & Breadth $(\mathrm{B} / \mathrm{H})$ & Umbilicus (\%) \\
\hline Holotype of $H$. mickeyi & 59.5 & 21.5 & $11.0(0.51)$ & $23.0(38)$ \\
\hline UCLA. 28826 & $\left\{\begin{array}{l}46.0 \\
40.8\end{array}\right.$ & $\begin{array}{l}18.3 \\
15.9\end{array}$ & $\overline{8.5}(0.53)$ & $\begin{array}{l}16.1(35) \\
14.3(35)\end{array}$ \\
\hline UCLA. 28824 & - & 26.3 & $12.8(0.48)$ & - \\
\hline UCLA. 28825 & 31.8 & 13.3 & $7.2(0.54)$ & - \\
\hline Holotype (GT. I-254) & 33 & 14 & $7 \quad(0.5)$ & $11 \quad(33)$ \\
\hline GT. I-3852 & 41.3 & 15.5 & $8.7(0.55)$ & $15.5(37.5)$ \\
\hline
\end{tabular}

For other Japanese examples see MATSUMoto and OBATA, 1956, p. 138-139.

Descriptive remarks.-The specific diagnosis and the distinction from Hauericeras (Gardeniceras) gardeni (BAILY) have been fully given by MATSUмото and ОвАтA (1956, p. 139-144). They also reviewed the specimens from India and British Columbia, which had been called Hauericeras gardeni but which they referred to $H$. (G.) angustum in the emended sense.

The Californian specimens listed above can also be assigned to $H$. (G.) angustum from every diagnostic feature. As MATSUMoto and OBATA remarked, the proportion between whorl-breadth and height and that between width of umbilicus and diameter of shell vary with growth. This is well exemplified in a diagram and the measurements of the Californian specimens clearly conform with the line of $H$. (G.) angustum (see Matsumoto and OватA, 1956, text-figs. 11, 12). The constrictions are weak, gently sigmoidal on the flank, and very infrequent on the whorl of the late growth-stage, as in the Japanese examples.

As the holotype of Hauericeras mickeyi ANDERSON (1958, pl. 47, fig. 2, 2a) has proved to be an immature specimen of $H$. (G.) angustum YABE (1904, emended MAтsumoto and OBATA, 1956), the specific name mickeyi should be suppressed as a synonym of angustum.

The holotype, LSJU. 390, of Hauericeras transitionale WARING (1917, p. 69, pl. 9, fig. 15), from loc. LSJU. 2, Los Angeles County, is too crushed for accurate measurements. Therefore I cannot decide whether it is referable to $H$. angustum or not.

Occurrence.-Locs. CIT. 1017, CIT. 1226, UCLA. 3633, UCLA. 3624 (cf.), and CAS. 27835, all in Chico Creek, upper part of the lower half of the section of the Chico formation in the type area. From the stratigraphic position and the associated species, Baculites capensis WooDs and Polyptychoceras cf. obstrictum (JIMBo), the beds from which $H$. (G.) angustum came are assigned to the Santonian. In Japan and South Sakhalin the species is common in the Santonian and ranges upwards in the lower part of the Campanian (Infrahetonaian).

Family Muniericeratidae WrIGHT, 1952

Genus Tragodesmoceras SPATH, 1922

Type-species.-Desmoceras clypealoide LEONHARDT, 1897.

Generic diagnosis.-See WRIGHT (in MOORE [Editor]) 1957, p. L381. 


\section{Tragodesmoceras ashlandicum (ANDERSON)}

Pl. 5, fig. 1a, b; Text-figs. 8-10

1902. Desmoceras ashlandicum Anderson, Proc. Calif. Acad. Sci., 3rd ser., vol. 2, p. 100, pl. 4, figs. 107, 109.

1956. Tragodesmoceras ashlandicum, Peck, IMLAY, and Popenoe, Bull. Amer. Ass. Petrol. Geol., vol. 40, p. 1979 (listed only).

1958. Pachydiscus ashlandicus, Anderson, Geol. Soc. Amer., Memoir 71, p. 221, pl. 27, figs. 3, 3a, 4, 4a.

1958. Pachydiscus oregonensis ANDERSON, Geol. Soc. Amer., Memoir 71, p. 221, pl. 27, figs. 2, 2 a.

Holotype.-CAS. 33, illustrated by ANDERSON (1902, Pl. 4, figs. 107, 109; 1958, pl. 27, figs. 3, 3a), from loc. CAS. 446, "4 miles southeast of Ashland, Oregon."

Material.-In addition to ANDERson's holotype and paratype the following specimens are referred to this species:

The holotype of "Pachydiscus oregonensis" ANDERSON (1958, pl. 27, figs. 2, 2a)

UCLA. 28798 (Pl. 5, fig. 1a, b; Text-fig. 8), from loc. CIT. 1444 (Coll. W. P. Popenoe)

A fragmentary specimen (Text-fig.9), from loc. CIT. 1195 (Coll. W. P. POPENOE \& AHLROTH)

Another fragmentary whorl (Text-fig. 10), from loc. CIT. 1208 (Coll. W. P. POPENOE \& AHLROTH)

\begin{tabular}{|c|c|c|c|c|}
\hline Specimen & Diameter & Height & Breadth $(\mathrm{B} / \mathrm{H})$ & Umbilicus $(\%)$ \\
\hline CAS. 33 (holotype) & 77.5 & 32.0 & $25.0(0.78)$ & $21.5(27)$ \\
\hline "P. oregonensis" & c. $105(?)$ & 49 & $34 \quad(0.69)$ & $24.5(24)$ \\
\hline UCLA. 28798 & 162 & 69.5 & $61.5(0.88)$ & $47.8(29)$ \\
\hline$\prime \prime \quad$ (intercostal) & 162 & 69.5 & $56.5(0.81)$ & \\
\hline "' (early) & - & 51.0 & $37.5(0.73)$ & 32.3 \\
\hline$\prime \prime$ (intercostal) & & 51.0 & $36.0(0.70)$ & \\
\hline One from loc. CIT. 1195 & - & 46.0 & $31.0(0.67)$ & 一 \\
\hline One from loc. CIT. 1208 & - & 30.0 & $23.3(0.77)$ & - \\
\hline
\end{tabular}

Diagnosis.-The full-grown shell is large. It is moderately involute, slightly more than a half of the inner whorl being overlapped by the outer. The whorl is higher than broad, the proportion ranging from 0.67 to 0.88 in the available data, broadest at a position slightly above the umbilical margin, and gradually convergent towards the venter. The flank is slightly inflated in a general view but more flattened on the lower part; the mature whorl is more inflated than the immature. The venter is fastigate, but the mid-venter tends to be rounded on the outer whorl. The umbilicus is fairly narrow to moderate, being 23 to 29 percent of the diameter on the basis of the available data. The umbilical wall is nearly vertical and has a subangular shoulder.

The whorl is ornamented with ribs of unequal length. Every third, fourth, or fifth is longer and somewhat stronger than others, sinuous on the flank, starting from the umbilical shoulder, where they are slightly elevated, if not 
distinctly tuberculate. The shorter ribs appear near or somewhat above the middle of the flank. Both the longer and shorter ribs are projected on the venter, tending to form obtuse chevrons. On the ventral part of the whorl of middle growth-stage the ribs are of moderate strength and separated by slightly broader interspaces. On the adult whorl the major ribs are broadened, and straightened or slightly projected, fading away towards the venter, while all the minor ribs are much weakened or nearly obsolete.

The suture is very similar to that of Gardeniceras, and accordingly to that of Puzosia, having a large, assymmetrically trifid L, which is deeper than E, and remarkably descending auxiliaries.

Remarks.-As compared with the type-species, T. clypealoide (LEONHARDT)
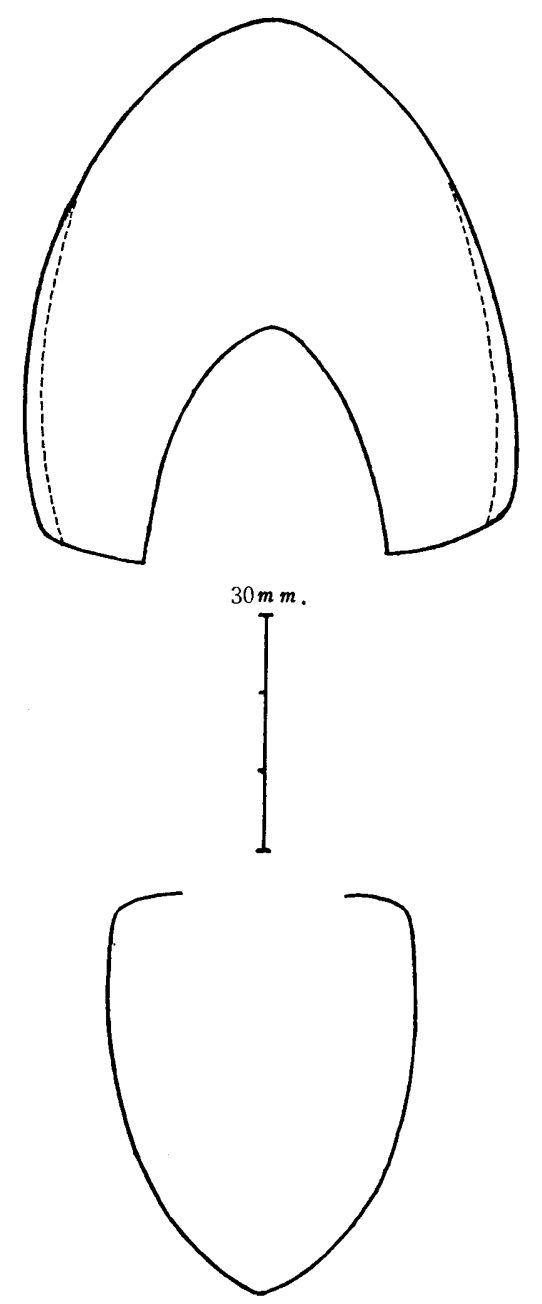

Fig. 8. Tragodesmoceras ashlandicum (ANDERSON). Cross section of an example, UCLA. 28798, from loc. CIT. 1444, Member I of the Redding area. See Pl. 5, fig. 1a, b for other views. 


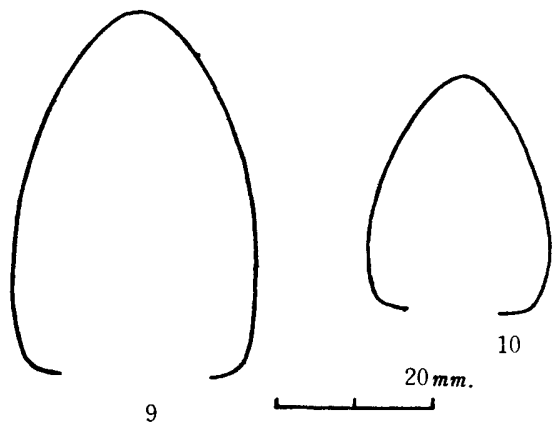

Figs. 9, 10. Tragodesmoceras ashlandicum (ANDERSON).

9. A specimen from loc. CIT. 1195, Member I of the Redding area, Shasta County.

10. Another from loc. CIT. 1208, Member I of the Redding area.

(1897, p. 57, pl. 6, fig. 2), from the Turonian of Europe, and its allied species, $T$. clypeale (ScHLÜTER) (1872, p. 51, pl.15, figs. 9-14), from the Coniacian of Europe, T. ashlandicum is larger, more evolute, and has the suture of Puzosia type rather than Desmoceras type. The slight elevation at the umbilical end of the major rib is another feature peculiar to the present species, but is not so strongly tuberculate as in Muniericeras.

While T. clypealoide and T. clypeale seem to have affinity with such members of the Desmoceratinae as Pseudouhligella and Tragodesmoceroides, T. ashlandicum is apparently similar to such members of the Puzosiinae as Austiniceras and Mesopuzosia. There might be parallel development in species groups derived from different stocks, but the evidence for tracing the origin of the present species is not yet sufficient to allow the establishment of a new genus. It should be also noted that the present species in some respects resembles Hauericeras (s.l.)

In the Western Interior province there are certain forms which are similar to the present species. An example was kindly shown to me by Dr. CoBbAN in his collection. T. bassi MonRow (1935, p. 468, pl. 52, figs. 1a-c; pl. 53, figs. 3-5; text-figs. 1, 3), from the Jetmore member of the Greenhorn formation, Kansas, may be another example. There is also a form, as represented by an immature specimen, from the Carlile shale, Wyoming, now preserved in C. W. WRIGHT's collection, which is somewhat intermediate between $T$. clypealoide and a more evolute form.

A large specimen from California, UCLA. 28798 (Pl. 5, fig. 1a, b) is interesting in that it shows the change of characters with growth. Although its adult whorl is somewhat inflated, its inner whorl is less so, being close to ANDERson's holotype. If we plot the proportion of height and breadth on a diagram, a smoothly curved line is obtained (Fig. 11). The holotype of "Pachydiscus oregonensis" ANDERSON (1958, p. 221, pl. 27, figs. 2, 2a) in its dimensions falls on the same line. From this and other points this specimen is proved to be referable to $T$. ashlandicum, and thus the specific name oregonensis should be 


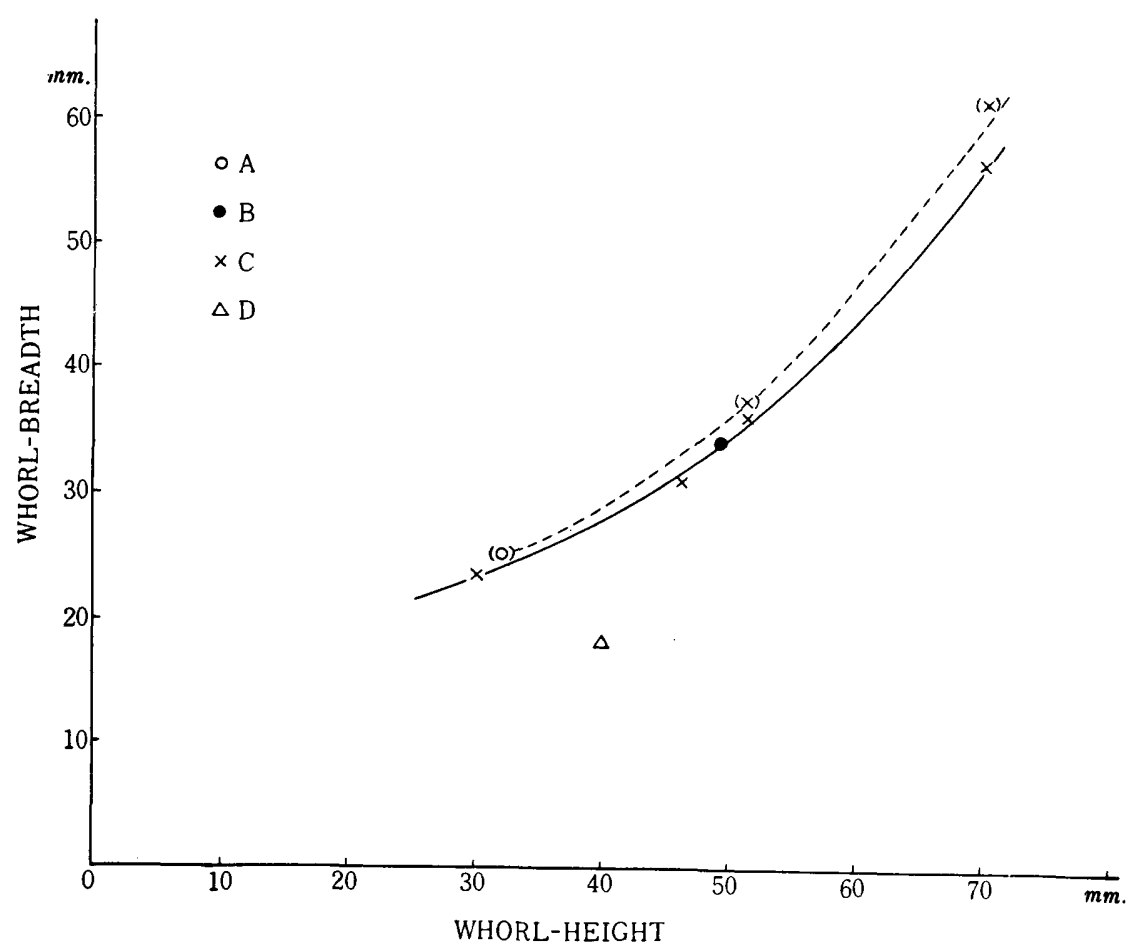

Fig. 11. Diagram showing the proportion between breadth and height of whorls in Tragodesmoceras ashlandicum (ANDERSON). A: holotype of T. ashlandicum; B: "T. oregonensis" ANDERson; C: other examples of T. ashlandicum; D: T. averilli ANDERSON (for comparison); ( ): intercostal measurements.

suppressed. The holotype of “Pachydiscus averilli” ANDERson (1958, p. 222, pl. 7, figs. 4, 4a) in its dimension deviates considerably from the line and is more weakly ornamented. This may be a different species, although it is referable to Tragodesmoceras.

Occurrence.-Type locality CAS. 446, "4 miles southeast of Ashland, Oregon". Another locality is recorded as "Forty-nine mine near Phoenix, Oregon" (ANDERSON, 1958, p. 221, for "P. oregonensis"). The stratigraphic position for these localities have not precisely described, but PeCK, IMLAY, and Popenoe (1956, p. 1979) listed T. ashlandicum as one of the species in their Members I \& II of the Hornbrook formation of the general area of southwestern Oregon and northern California.

Locs. CIT. 1444, CIT. 1195, and CIT. 1208 in sandstones of Member I of the Redding area, Shasta County, California. This member is best referred to the Turonian from its stratigraphic position and contained fossils.

Family Pachydiscidae Spath, 1922

In California the pachydiscids occur fairly commonly, but are confined to 
the upper part of the Upper Cretaceous. They are represented by Eupachydiscus, Anapachydiscus, Pachydiscus, Canadoceras, and Patagiosites. No species of Eopachydiscus, Lewesiceras, and Pachydiscoides have been found there.

While the various, interesting examples of the bituberculate pachydiscids are known in Japan and Sakhalin (see MAтsumoto, 1955b), very few occur in California. Among the specimens at my disposal there are only two, crushed specimens of Menuites sp., from loc. CIT. 623, Point Conception, Santa Barbara County (Coll. J. Dorrance) and loc. CAS. 13289, Point Loma, San Diego County (no record of collector). Another, small, very poorly preserved specimen, from loc. LSJU. 1999, west side of the Capay Valley, Yolo County (Coll. J. M. KIRBY), may be comparable with Menuites pussilus Matsumoto (1955b, p. 165, pl. 32, figs. 1a-d, 2a-d, 3a-c, 4a, b), but cannot be identified with certainty.

Genus Eupachydiscus Spath, 1922

Type-species.-Ammonites isculensis REDTENBACHER, 1893, by original designation.

Synonym.-Mesopachydiscus YABE and SHIMIZU, 1926.

Generic diagnosis.-See Matsumoto, 1954a (p. 281); Wright in Moore [Editor], 1957, p. L380. The constriction was accounted as one of the diagnostic features of this genus in my older papers $(1947$, p. $37 ; 1951$, p. 22), but this should not be stressed too much, because on the outer whorl it may or may not develop depending on species.

Remarks.-This strongly ribbed genus is readily identified. It is common in the upper part of the Urakawan in the Japanese province, approximately equivalents of the Santonian plus (?) Lower Campanian, but the type-species occurs, according to BRINKMANN (1935), in the Upper Coniacian and Lower Santonian of the Alpine Gosau beds. Whether Eupachydiscus was derived from Lewesiceras, Anapachydiscus, or otherwise is not clear in our present knowledge. It cannot be overlooked, however, that a Coniacian example from California, to be described below, resembles a certain species of Lewesiceras.

I have recognized the following species of Eupachydiscus in the Upper Cretaceous of the West Coast.

(1) Eupachydiscus sp. aff. E. teshioensis (JIMBo)

(2) Eupachydiscus haradai (ЈІмво), including "Pachydiscus perplicatus" WHITEAVES and "Pachydiscus haradai" of UsHeR (1952)

(3) Eupachydiscus sp. cf. E. levyi (DE GROSSOUVRE)

(4) Eupachydiscus sp. nov. (?) aff. E. lamberti Collignon

I describe here the first two species. The third species is represented only by a small, probably immature, specimen, from "a mine shaft underneath the lavas, Manton, California", donated by Mr. H. E. Vokes to Stanford University. In spite of its small size the specimen has already distant and rather rectiradiate ribs, which are normally found on the adult whorl of E. levyi (Grossouvre) (1894, p. 178, pl. 21 ; pl. 30, figs. 1, 2), from the Alps-Maritimes and the Campanian 
of Madagascar (Collignon, 1938, p. 14, pl. 3, figs. 3, 3a; text-fig. A; 1955, p. 34). The fourth species resembles $E$. lamberti (Collignon) (1938, p. 35, pl. 5, figs. 3, $3 \mathrm{a}, 3 \mathrm{~b} ; 1955$, p. 45, pl. 10, figs. 1, 1a, 1b), from the "middle Campanian" of Madagascar, in the relatively high outer whorl, which is ornamented with distant, rather rectiradiate, strong ribs. The species is represented by two gigantic specimens, UCLA, 28683 and 28684 (Pl. 7, figs. 1a-c, 2) from loc. UCLA. 3956, Santa Monica Mountains, California, now preserved at the University of California at Los Angeles. There is another comparable, fragmentary, body whorl, from the Santa Ana Mountains, in the collection of Standford University. Another well preserved specimen, which Dr. D. L. JoNEs showed me in his collection at the U. S. Geological Survey, Menlo Park, may be allied to this species. One of the differences between the species from Madagascar and California is that the ribs are weakened or interrupted on the siphonal line in the former but rather exaggerated in the latter. The full description of this interesting, probably new species will be given by Dr. JoNEs.

\section{Eupachydiscus sp. aff. E. teshioensis (JIMBo) Pl. 6, figs. 1a-c; Text-fig. 12}

Compare.-

1874. Pachydiscus teshioensis Јıмво, Pal. Abh., Bd. 6 [N.F. 2], p. 30 [176], pl. 3 [19], figs. 1, 1a, 1b.

Holotype of E. teshioensis (JIMBo).--An original specimen of Jiмво (1894, pl. 3 [19], figs. 1, 1a, 1b), from the Upper Cretaceous of the "Tsikapunnai", Abeshinai area, Teshio Province, Hokkaido.

Material.-The Californian specimens which I describe under the above heading are as follows :

UCLA. 28799 (Pl. 6, figs. 1a-c; Text-fig. 12), from loc. UCLA. 3368 (Coll. James VALENTINE)

A fragmentary, inner whorl, from loc. UCLA. 3782 (Coll. W. P. PoPENOE) Another specimen of moderate size, from loc. UCLA. 3783 (Coll. W. P. Popenoe) ; others from loc. SOC. K-53, 55 (Coll. KenNell \& ROBINS)

Measurements.-

\begin{tabular}{|c|c|c|c|c|}
\hline Specimen & Diameter & Height & Breadth $(\mathrm{B} / \mathrm{H})$ & Umbilicus (\%) \\
\hline Holotype (deformed) & 249.0 & 85.0 & $142.0(1.66)$ & $82.0(33)$ \\
\hline GK. H 3414 (hypotype) & 220 & 72.0 & $104.5(1.45)$ & $65.3(29.7)$ \\
\hline UCLA. 28799 & 106.5 & 49.5 & $63.5(1.28)$ & $30.0(28)$ \\
\hline$(1 / 2$ vol. early $)$ & - & 33.0 & $39.6(1.20)$ & - \\
\hline One from loc. 3782 & - & 22.0 & $30.2(1.34)$ & - \\
\hline One from loc. 3783 & 57.0 & 25.5 & $30.9(1.21)$ & $12.5(22)$ \\
\hline $\begin{array}{l}\text { Holotype of } L . \text { beantalyense } \\
\text { (after CoLLIGNON) }\end{array}$ & se 72 & 35 & $(1.54)$ & (29) \\
\hline $\begin{array}{l}\text { L. tongoboryense (after } \\
\text { CoLLIGNON) }\end{array}$ & 59 & 27 & $38 \quad(1.40)$ & (31) \\
\hline
\end{tabular}

Descriptive remarks.-In the relatively inflated and depressed whorls and the arcuate and strong ribs, the Californian specimens under consideration are best comparable with Eupachydiscus teshioensis (JIMBO) from Japan. The 
Japanese examples, including the holotype, are much larger than the largest specimen of California. The latter is regarded as adult, because the body whorl, with adjacent septate part, shows the strong ribbing. The observable suture of the Californian specimen is less finely incised than that of the Japanese ones, although the general pattern is quite similar. The tubercles are bullate as in the Japanese species.

It should be noted that a shallow constriction-like depression can be discerned periodically along some of the major ribs. On the smaller or inner whorls the ribs are narower and less distant than those on the outer whorl. Thus the shell below a diameter of $80 \mathrm{~mm}$. is close to Lewesiceras beantalyense Collignon (1955, p. 22, pl. 1, figs. 2, 2a, 2b, 3, 3a, 3b; pl. 2, figs. 1, 1a, 2, 2a, 2b; text-fig. 1) and Lewesiceras tongoboryense Collignon (1955, p. 25, pl. 2, figs. 3, 3a, 3b), from the Lower Coniacian of Madagascar. The first of the Madagascar species has relatively stronger ornament and much more depressed whorls than the Californian specimens even on shells of small size. The probably adult whorl of the Californian species has coarser and more widely spaced ribs and much larger than the presumably adult (see CollignoN, 1956) shells of the two Madagascar species. Thus the California species is closer to Eupachydiscus teshioensis (ЈIMBO) of the Japanese Santonian. Anyhow the California species is interesting in that it is, at least apparently, intermediate between certain species of Lewesiceras and the relatively inflated and indistinctly constricted species of

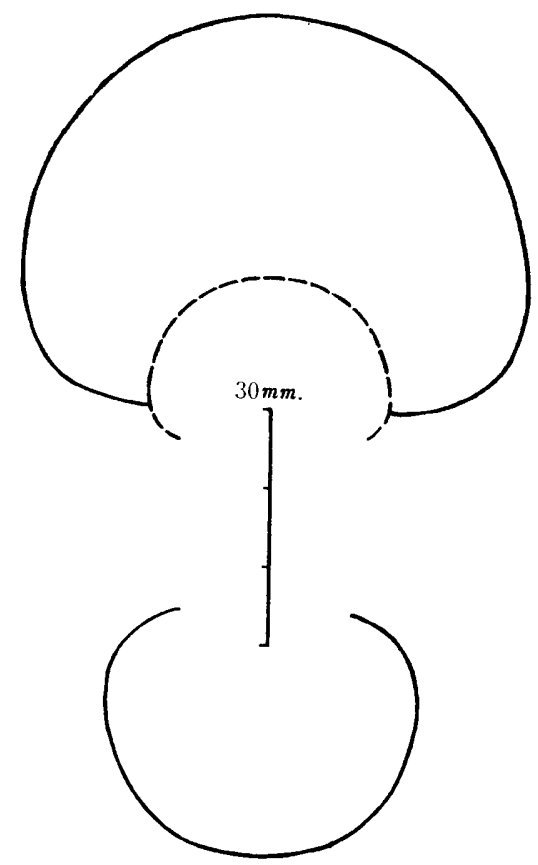

Fig. 12. Eupachydiscus sp. aff. E. teshioensis (JIMBo). Cross section of an example. UCLA. 28799, from loc. UCLA. 3368, Member IV of the Redding area, Shasta County. See Pl. 6, fig. 1a-c for other views. 
Eupachydiscus.

Eupachydiscus isculensis (REDTENBACHER) (1893, p. 122, pl. 29, fig. 1) seems to have arcuate ribs on the figured type of REDTENBACHER, being apparently similar to E. teshioensis. But according to the interpretation of subsequent authors (Grossouvre, 1894; CoLligNoN, 1932, 1956) it has less remarkably arcuate ribs and much less depressed whorls than $E$. teshioensis. Therefore it may be closer to $E$. haradai (JIMBO), but no constriction has been found on the outer whorls of $E$. isculensis. In France and Madagascar $E$. isculensis ocurs in the Upper Santonian and Lower Campanian (Collignon, 1955, p. 79 ).

Occurrence.-Locs. UCLA. 3368, UCLA. 3782, UCLA. 3783, and SOC. K-53, 55 all in Member IV of the valleys of Oak Run and Clover Creek, Redding area, northeastern side of the Sacramento Valley. In the same member IV of this area Damesites damesi intermedius Matsumoto, Prionocycloceras sp. Peroniceras shastense ANDERson, Baculites schencki MATsumoto, etc. occur. Therefore the geological age of Eupachydiscus sp. aff. E. teshioensis is best referred to the upper part of the Coniacian, being somewhat older than that of E. teshioensis in the Japanese province.

\section{Eupachydiscus haradai (JIмBo) \\ Text-figs. 13-15}

1861. Ammonites complexus var. suciaensis MEEK (pro parte), Proc. Acad. Nat. Sci., Philadelphia, vol. 13, p. 317.

1876. Ammonites complexus ? var. suciaensis, MeEK (pro parte), Bull. U.S. Geol. Geogr. Surv. Terr., vol. 2, no. 4, p.369, pl.5, figs. 2b, c (non pl.5, figs. 2, 2a).

1894. Pachydiscus haradai Jıмво, Pal. Abh., Bd. 6 [N. F. 2], p. 29, pl. 2 [18], figs. 2, 2a, 2b.

1895. Pachydiscus haradai, Whiteaves, Trans. Roy. Soc. Canada, 2nd ser., vol. 1 , sec. 4 , p. 132 , pl. 3 , fig. 6 .

1903. Pachydiscus haradai, Whitfaves, Mesozoic Fossils, vol.1, pt.5, p. 345.

1903. Pachydiscus perplicatus Whiteaves, Mesozoic Fossils, vol.1, pt. 5, p. 346, pl. 48, fig. 1.

1922. Eupachydiscus haradai, SPath, Trans. Roy. Soc. S. Africa, vol. 10, p. 124.

1926. Mesopachydiscus haradai, YABE and ShImIzU, Proc. Imp. Acad. Japan, vol. 2, p. 172.

1927. Parapachydiscus (Mesopachydiscus) haradai, YABE, Sci. Rep., Tohoku Imp. Univ., 2nd ser., vol. 11, pl. 7, figs. 10a, b.

1938. Eupachydiscus haradai, Collignon, Ann. Géol. Serv. Mines, Madagascar, vol. 9, p. 28, pl. 4, fig. 4, 4a.

1952. Pachydiscus (Eupachydiscus ?) haradai, Usher, Geol. Surv. Canada, Bull. 21, p. 73, pl. 12, figs. 2-4; pl. 13, figs. 1-3; pl. 31, fig. 6 .

1952. Pachydiscus sp. cf. P. haradai, Usher, Ibid., p. 77.

1952. Pachydiscus perplicatus, UsHeR, Ibid., p. 77, pl.12, fig. 1; pl. 13, figs. 4-6; pl.14, figs. 1-3; pl.15, figs. 1, 2; pl. 31, fig. 5 .

1954. Eupachydiscus haradai, Matsuмото, Cret. System Japan Islands, Appendix, p. 281, pl. 8 [24], fig. $2 \mathrm{a}$, b; pl. 9 [25], figs. 1, 2, 3a, b; pl. 10 [26], figs. 1a, b, 2, 3; text-figs. 14-17 [60-63]. 
1955. Eupachydiscus haradai, Collignon, Ann. Géol. Serv. Mines, Madagascar, vol. 21, p. 44, pl. 9, fig. 1, 1a, $1 \mathrm{~b}$.

1958. Fagesia klamathensis ANDERson, Geol. Soc. Amer., Memoir 71, p. 248, pl. 28, fig. 3, 3a.

Holotype.-The specimen, GT. I-100, from "Abeshinai", Teshio Province, Hokkaido, illustrated by Jімво (1894, p. 29, pl. 2 [18], fig. 2, 2a 2b) (also MAтsumoтo, 1954a, pl. 10 [26], figs. 1a-b, 2, 3).

Specific diagnosis.-See Matsumoto, 1954a, p. 283-285.

Remarks.-I have already (MATSUмото, 1954a, p. 285-286) suggested that "Pachydiscus haradai" from the Haslam formation of Nanaimo group (WHITEAveS 1895, p. 132, pl. 3, fig. 6 Usher, 1952, p. 73, pl. 12, figs. 2-4; pl. 13, figs. 1-3; pl. 31, fig. 6) could be subspecifically distinguished from the typical form of $E$. haradai from Japan. The proportion between the whorl-height and breadth varies to some extent, but the Canadian specimens which have been called $E$. haradai are always more compressed than the Japanese ones. This can be clearly indicated by a graph (Text-fig. 15) which shows two deviating curves. Thus subspecific separation is established as follows:

(a) Eupachydiscus haradai haradai (ЈІмво)

Holotype.-GT. I-100, as indicate above. The Japanese specimens which I (Matsumoto, 1954a, p. 281) listed previously belong to this subspecies.*

Diagnosis.-The whorl is relatively inflated and somewhat broader than high, with $\mathrm{B} / \mathrm{H}=1.15 \pm 0.10$ in the later growth-stages.

(b) Eupachydiscus haradai usheri subsp. nov.

Holotype.-GSC. 5448 (Usher, 1952, pl. 12, figs. 2-4). Almost all the specimens which have been listed under Pachydiscus (Eupachydiscus) haradai by UsHeR (1952, p. 73) belong to this subspecies.

Diagnosis. - The whorl is relatively flattened and nearly as broad as high or slightly higher than broad, with $\mathrm{B} / \mathrm{H}=0.95 \pm 0.05$ in the later growth-stages.

There may be a few exceptions to the above figures of $\mathrm{B} / \mathrm{H}$. For instance, a relatively compressed specimen from South Sakhalin, GK. H 5207 (Matsumoto, 1954a, pl. 8 [24], figs. 2a, b) has the outer whorl which is nearly as high as broad $(\mathrm{B} / \mathrm{H}=1.0)$, but is still nearly at the average of the dimensions of $E$. haradai haradai in the slightly earlier growth-stage (see Fig. 15).

$E$. haradai usheri is very similar in the shell-form to $E$. pseudogrossouvrei Collignon (1956, p. 42, pl. 3, figs. 1, 1a, 2, 2a; text-fig. 9), from the Middle Campanian of Madagascar, but its ribs are as coarse as those of $E$. haradai haradai and it has, up to the middle growth-stage, a constriction-like shallow depression occurring periodically along some of the major ribs.

Almost all the specimens which have been assigned to Pachydiscus perplicatus Whiteaves (1903, p. 346, pl. 48, fig. 1; Usher, 1952, p. 77, pl. 12, fig. 1; pl. 13, figs. 4-6; pl. 14, figs. 1-3; pl. 15, figs. 1, 2; pl. 31, fig. 5), from the Trent River

* Measurements of the holotype:

Diameter $=120.0 \quad$ Height $=48.0 \quad$ Breadth $=55.0 \quad \mathrm{~B} / \mathrm{H}=1.15 \quad$ Umbilicus $=32.0(26.6 \%)$

N.B. Height was misprinted as 43.0 in my previous paper (1954a, p. 282). 
formation of Nanaimo group, are referable to $E$. haradai haradai. Their dimensions, as listed by USHER (1952), are very similar to those of the Japanese examples. The difference, if existent, is too slight for the specific distinction. The available data, as seen in Fig. 15, are not sufficient for justifying even the subspecific separation, although this point must be examined by further study. The holotype of $P$. perplicatus, GSC. 5852 (WHITEAVEs, 1903, pl. 48, fig. 1; UsHer, 1952, pl. 12, fig. 1), is a large shell, unfortunately destroyed at one side, so that its dimensions cannot be precisely measured. Its ribs remind us rather of those of E. teshioensis (JIMBo) (1894, p. 30, pl. 3 [19], figs. 1, 1a, 1b), but its shell does not seem to be so depressed as in E. teshioensis. Generally the ribs on the adult whorl are relatively less strongly arcuate (concave on the side and projected towards the venter) in E. haradai than in $E$. teshioensis, but the character is variable and may be modified by secondary deformation. The holotype of $P$. perplicatus is, thus, probably an example of $E$. haradai haradai, just as other examples from the Trent River formation probably belong to that subspecies.

In the Californian specimens at my disposal those which are referable to E. haradai are very few. PeCk, Imlay, and Popenoe (1956, p. 1973, and p. 1980) listed "E. cf. E. perplicatus (Whiteaves)" and "E. cf. E. haradai (Jimbo)" in Member $\mathrm{V}$ of their Hornbrook formation in northern California. I had not enough time to examine their collections. From the same general area, "about 1/2 miles west of Henley", "Fagesia klamathensis" ANDERson (1958, p. 248, pl. 28, fig. 2, 2a) (Text-fig. 13 of this paper) has been reported. The holotype of ANDERSON's species is nothing but an example of $E$. haradai haradai as defined above. It has the dimensions [diameter $=115.5$, height $=53.2$, breath $=62.0$ $(\mathrm{b} / \mathrm{h}=1.16)$ (costal), umbilicus $=28.4(24.5 \%)]$, which come on the average curve of that subspecies (see Text-fig. 15), the pachydiscid type of suture, and the ornament of $E$. haradai type.

Among other specimens from the West Coast, Ammonites complex var.

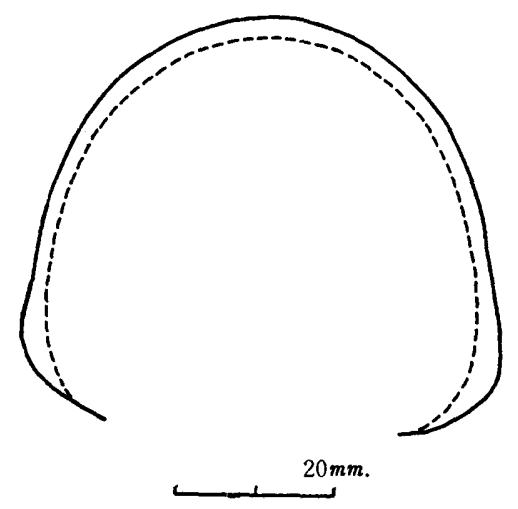

Fig. 13. Eupachydiscus haradai haradai (JIMBO). Whorl-section of a Californian example [=holotype of Fagesia klamathensis ANDERSON], from loc. CAS. 455, near Henley, Siskiyou County. 


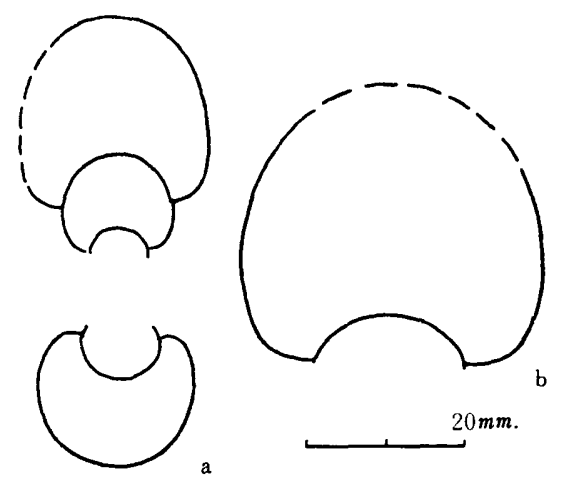

Fig. 14. Eupachydiscus cf. haradai usheri subsp. nov. Whorl-sections of the inner whorls. USNM. 12396, one of the syntypes of Ammonites complexus var. suciaensis MEEK. This is entirely different from the lectotype of Pachydiscus suciaensis (MEEK). See Pl. 9, figs. 1a, b, 2 for other views.

suciaensis MEEK (1861, p. 317) must be considered here. There are at least two syntypes for MeEK's suciaensis. One of them, USNM. 12396 from "Komooks, Vancouver Island" (MEEK, 1876, p. 369, pl. 5, fig. 2, 2a) (Pl. 8, fig. 1a-d in this paper), has nothing to do with Eupachydiscus haradai, and is here designated lectotype of Pachydiscus suciaensis (MEEK). The other syntype, USNM. 1276 from Sucial Island, which was also illustrated by MEeK (1876, pl. 5, fig. 2b, 2c), has a highly eroded outer whorl, which is more rounded and less compressed than the lectotype. By permission of the Curator of Invertebrate Paleontology, U. S. National Museum, I was allowed to examine the inner whorl of the same specimen. This specimen, as can be clearly seen from the illustrations in this paper (Pl. 9, figs. 1a, b, 2; Text-fig. 14), is not specifically identical with the lectotype of $P$. suciaensis, but is probably an example of E. haradai usheri. The ribs preserved on its inner whorl are as strong as those of immature shells of E. haradai. Its dimensions (d. 115 , h. 52 , b. 51 , u. 30 ; d. 67 , h. 25 , b. 25, u. 16) indicate that it comes on the line of E. haradai usheri (see Text-fig. 15). Since the outer whorl, which should have strong ribs, is too much eroded, the conclusive identification must be suspended. I should call the specimen under consideration Eupachydiscus cf. haradai usheri.

Several specimens from Madagascar have been described under the specific name $E$. haradai by Collignon (1938, p. 28, pl. 4, figs. 4, 4a; 1955, p. 44, pl. 9, figs. 1, 1a, 1b). Although I have not seen the actual specimens, from the precise descriptions and fine illustrations of CoLlignoN, I agree with him in assigning them to $E$. haradai. The dimensions measured by him mostly are situated between those of $E$. haradai haradai and $E$. haradai usheri. One of the illustrated specimens (CollignoN, 1955, pl.7, figs. 1, 1a, 1b, no. 376) is approximately on the line of $E$. haradai haradai. The shallow, constriction-like depression along some of the major ribs, which are discernible on the Japanese examples, were not mentioned by COLLIGNON about the specimens from Madagascar. This point cannot be confirmed without seeing the actual specimens. The specimens from 


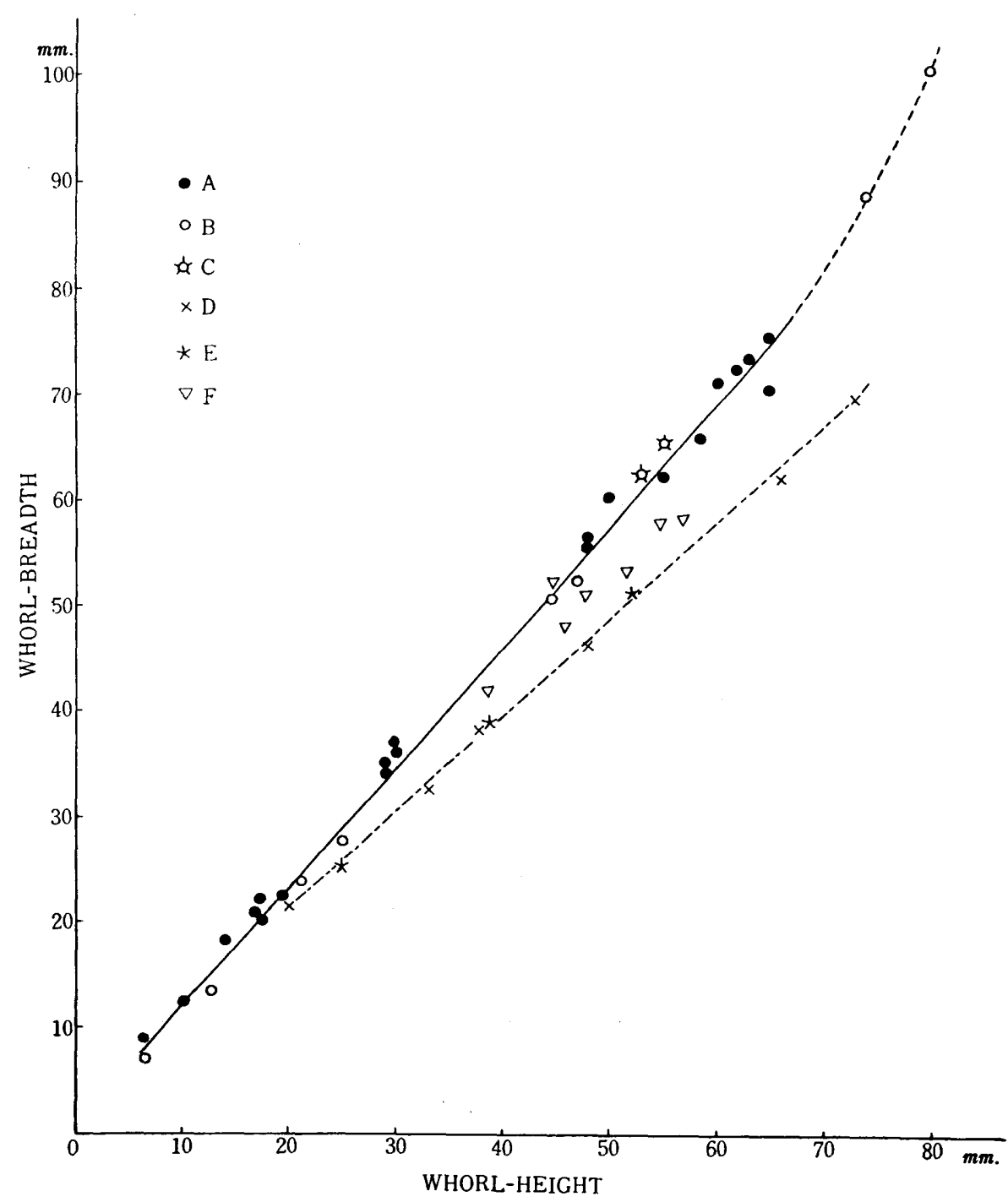

Fig. 15. Diagram showing the proportion between breadth and height of whorls in Eupachydiscus haradai (JIMBo). A: E. haradai haradai from Japan and Sakhalin; B: E. haradai haradai from the Nanaimo group [= E. perplicatus WhITEAvEs]; C: E. haradai haradai from California [= Fagesia klamathensis ANDERSon]; D: E. haradai usheri; E: E. cf. haradai usheri [=a syntype of Ammonites suciaensis MEEK (not lectotype)]; F: E. haradai from Madagascar.

Madagascar could perhaps constitute another subspecies of $E$. haradai, but the available records are not sufficient for the establishment of the subspecies.

Occurrence.-UsHeR's (1952) records of the occurrence in the Nanaimo group of Vancouver Island, British Columbia, can now be written as follows:

$E$. haradai haradai: Trent River formation 
E. haradai usheri: Haslam formation

$E$. cf. haradai usheri: Haslam formation (?) of Cowitchan area; and an indetermined part of Sucia Island

The two subspecies may be slightly heterochronous. UsHer (1952, text-fig. 2) concludes that the Haslam formation is older than the Trent River formation, although they are within the Campanian. A reversed order between them could be considered from the associated species.* The stratigraphic position of ANDERSON's specimen of $E$. haradai haradai [="Fagesia klamathensis"] in the northern part of California is not precisely known. According to the record on the label of that specimen, it is " 400 feet below the zone of Placenticeras [probably Metaplacenticeras in my interpretation], a half mile west of Henley." This should be higher than the Upper Turonian (Subprionocyclus bearing) beds.

In Japan and Sakhalin E. haradai haradai is common in the Upper and Uppermost Urakawan, approximately Upper Santonian plus Lower Campanian. The representatives of $E$. haradai in Madagascar have been ascribed to the Campanian.

Genus Anapachydiscus YABE and ShImizU, 1926

Type-species.-Pachydiscus (Parapachydiscus) fascicostatus YABE, 1921.

Generic diagnosis.-See Matsumoto, 1947 (p. 37) (in Japanese); 1951 (p. 22); 1954a (p. 272); and WrIGHT in MoORE [Editor], 1957, p. L380.

Remarks. - While Anapachydiscus occurs frequently in the Santonian [=Upper Urakawan] of Japan, it is reported to occur in the Upper Senonian of other areas, such as India and Madagascar. Probably the genus has a long geological range.

In California and adjacent areas there are several species that I refer to Anapachydiscus. The examples are as follows:

(1) A. californicus (YABE and SHIMIZU), described below

(2) A. arrialoorensis (SToLICZKA), represented by a specimen from loc. LSJU. 3354, Cholame Quadrangle, California

(3) A. peninsularis (ANDERson and HANNA) (1935, p. 20, pl. 4, fig. 4; pl. 5, figs. 1, 2; pl. 6, figs. 3 , 4; pl. 7, fig. 5; text-fig. 1), from loc. CAS. 1431, Baja California, which is fairly similar to A. arrialoorensis, but also resembles Pachydiscus colligatus (BINKHORST)

(4) A. deccanensis (STOLICZKA), represented by a specimen from loc.

* Inoceramus schmidti, an index of the Lower Hetonaian $(\div$ Middle and ? Upper Campanian), has been recorded at various horizons in the Nanaimo group. This is often misidentified with $I$. japonicus, an index of the Santonian. I have confirmed unmistakable $I$. schmidti and P. haradai usheri in the collection of USGS. Mes. loc. 26272, the type locality of the Haslam formation. "Ptychoceras vancouverense" WhitEAVES from the Trent River formation is close to Polyptychoceras pseudogaultinum (YokoYAMA), which is rather common in the Upper Urakawan (Santonian and Lower Campanian). 
LSJU. 3351, Santa Ana Mountains, and another from loc. SOC. K-235, Siskiyou County, California

(5) A. henleyensis (ANDERson) (1902, p. 104, pl. 8, figs. 165, 166; 1958, p. 224, pl.36, figs. 2, 2a, 2b), represented by two poorly preserved specimens, CAS. 22, 22a, from Henley, Siskiyou County

(6) A. (?) siskiyouensis (ANDERSON), the holotype of which was found near Henley, Siskiyou County

The last species was assigned to Fagesia by Anderson (1931, p. 125, pl. 17, figs. 2,3 ; 1958, p. 248, pl. 28, figs. 1, 2), but resembles A. koluturensis (SToLICZKA) (1865, p. 127, pl. 64, fig. 3, 3a-c) in the general aspect. The suture is not exposed on the holotype, CAS. No. 4689 , so it should be examined on topotypes.

A description in detail is given here only for the first species.

\section{Anapachydiscus californicus (YABE) \\ Text-figs. 16a, b}

1921. Pachydiscus (Parapachydiscus) fascicostatum $\mathrm{Y}_{\mathrm{ABE}}$ var. californica YABE in YABE and Shimizu, Sci. Rep. Tohoku Imp. Univ., 2nd ser., vol. 5, p. 58 [6], pl. 8 [1], fig. 4 ; text-fig. 5 .

Holotype.-GIS. 6210, illustrated by YABE and SHIMIZU (loc. cit.) from loc. UC. 2166, Santa Ana Mountains, California (Coll. E. L. PACKARD). The actual specimen was not at my disposal, but I examined a plastotype in Tohoku University.

Material.-In addition to the holotype, there are a few fragmentary whorls, from loc. LSJU. 3353 near Coalinga (Coll. W. R. HARMELON) and others from a locality in Orange County, locs. UC. A-9753, A-9754 (UC. Paleo. 137 Class, 1953), and loc. CAS. 31327, Yolo County.

Measurements.-

\begin{tabular}{|c|c|c|c|c|}
\hline Specimen & Diameter & Height & Breadth $(\mathrm{B} / \mathrm{H})$ & Umbilicus $(\%)$ \\
\hline GIS. 6210 & 148.5 & 76.0 & $73.2(+)(0.96)$ & c. $33.5(22)$ \\
\hline$/ \prime \quad(1 / 2$ vol. early $)$ & - & 41.8 & $(1.23)$ & - \\
\hline Another & - & c. 230 & c. 206 & - \\
\hline
\end{tabular}

Diagnosis.-The shell reaches a large size; the outer whorl of the holotype is still septate. It is moderately involute and fairly narrowly umbilicate. The whorl is broader than high in the earlier growth-stages, but is nearly as broad as high or even slightly higher than broad in the large, late growth-stage (see Text-fig. 16a, b). It is rather rounded in cross section, with a rounded umbilical shoulder, but it tends to be suboval in the late growth-stage, being broadest in the dorsal part.

The whorl is ornamented with numerous, fine, radial ribs, which are narrower than the interspaces. Several spring in bundles from blunt umbilical tubercles, but others are free from the tubercle. The ribs are slightly concave on the flank, projecting gently towards the venter. Some of the ribs may be slightly more distinct than others. The umbilical tubercles are depressed, even when the test is preserved, broad and moderately spaced on the outer whorl, but may 


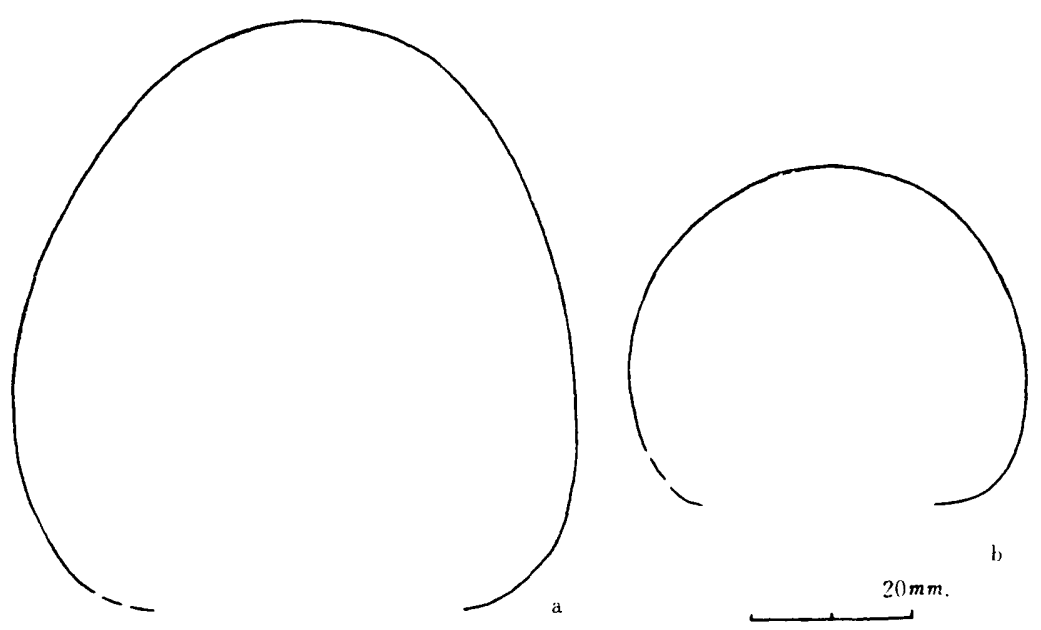

Fig. 16. Anapachydiscus californicus (YABE and SHIMIZU). Whorl-sections at two different growth-stages (a, b). GIS. 6210 , a plaster cast of the holotype from the Santa Ana Mountains.

be narrow on the inner whorl. The large, last whorl is nearly smooth.

The suture, which is partly exposed on the holotype but wholy exposed on other specimens, is very similar to that of A. fascicostatus (YABE) (see YABE and SHimizu, 1921, pl. 9 [2], fig. 2a-e).

Remarks.-YABE (in YABE and SHImizU, 1921, p. 58) correctly pointed out the difference of this Californian form from typical examples of $A$. fascicostatus (YABE) (in YABE and Shrmizu, 1921, p. 57, pl. 8 [1], fig. 5, pl. 9 [2], fig. 2a-e), from Japan, but treated the former temporarily as a variety, because the material at his disposal was not sufficient for clear specific distinction.

Now we have a large number of Japanese specimens of $A$. fascicostatus and there are also several of the Californian form. There is a constant difference that the Japanese examples have much depressed and inflated whorls, but the Californian ones less depressed and higher whorls. When the whorls of the corresponding size are compared, the latter have finer and more numerous ribs than the former. Therefore the specific distinction is now undoubted.

Despite these differences the two species have many common features. $A$. californicus is probably derived from $A$. fascicostatus. It is also interesting to note that, in the fine ribbing, depressed tubercles, and relatively high whorl, A. californicus may lead to Pachydiscus (Neodesmoceras) catarinae (ANDERSON and HaNnA) (1935, p. 19, pl. 1, fig. 1; pl. 2, fig. 1; pl. 3, fig. 1; non pl. 3, figs. 2, 3 ) ; on the latter very faint riblets, with a curvature similar to that of the ribs of the former, can be discernible under an oblique light.

Occurrence.-The type locality is loc. UC. 2166 (see PACKARD, 1922, p. 416) in Black Star Canyon, Santa Ana Mountains, California. The assignement of the fossiliferous bed to the "Middle Chico" (see YABE and SHimizu, 1921, p. 58) may be out of date, but I have no more accurate information about the strati- 
graphic position of this type locality.

Another locality for a specimen in the collection of Stanford University is "about 1/4 mile south of San Juan Canyon and about 4 miles east of San Juan Capistrano, Orange County, Calif."

Loc. CAS. 31327, probably Forbes formation, Rumsey Quadrangle, Yolo County, west side of the Sacramento Valley.

Loc. UC. A-9754, Ortigalita Peak Quadrangle, west side of the San Joaquin Valley (comparable specimen).

One more locality (LSJU. 3353) for another specimen of the collection of Stanford University is only recorded as "Coalinga, California".

\section{Genus Pachydiscus ZITTEL, 1884}

Type-species.-Ammonites neubergicus VAN HAUER, 1858, by subsequent designation by DE GROSSOUVRE (1894, p. 177).

Synonym.-Parapachydiscus HYATT, 1900; ? Joaquinites ANDERSON, 1958.

Generic diagnosis.—See Matsumoto, 1947 (p. 39); 1951 (p. 23); 1954a (p. 287); and WRIGHT in MOORE [Editor], 1957, p. L380.

Remarks.-Typical examples of the genus are $P$. neubergicus (HAUER), P. egertoni (ForBES), P. gollevillensis (D'ORBIGNY), P. compressus (SPATH) and $P$. subcompressus MATSUMoTo. There is, in addition, a group of species which is rather intermediate between Anapachydiscus and Pachydiscus (s.s.). $P$. colligatus (BINKHORST) is such a species, but it and other allied species are more compressed than the typical form of Anapachydiscus and, accordingly, can be included in Pachydiscus.

Another group of species which is characterised by much reduced ornament all through the ontogenetic development has been classified as a subgenus, Neodesmoceras Matsumoto, 1947 (see also MATsumoto and SAITo, 1954).

In California and adjacent areas there are representatives of all these three groups, as follows:

(1) Typical subgroup: Pachydiscus (s.s.) egertoni (ForBes) and $P$. (s.s.) cf. subcompressus Matsumoto

(2) Transitional to Anapachydiscus: Pachydiscus buckhami UsHeR (emended below)

(3) Subgenus Neodesmoceras: P. (Neodesmoceras) catarinae (ANDERsoN and HANNA)

The last species has already been well defined by the original authors (1935) and occurs mainly in Baja California, so it is not redescribed in this paper.

Pachydiscus ootacodensis (SToliczKA) (1865, p. 109, pl. 54, figs. 3, 4; pl. 56) and $P$. neevesi Whiteaves (1903, p. 342, pl. 47, fig. 1 ; text-fig. 21 ) tend to approach to $P$. (Neodesmoceras) in their obsolete umbilical tubercles and weakening ribs. The two species resemble each other but are distinguishable by more flattened flanks and finer ribs of $P$. neevesi. They occur in the Nanaimo group of Vancouver Island. As they have been described in detail by UsHER (1952), 
I omit here the redescription, although there are several examples of them in California as follows:

P. cf. ootacodensis (STOLICZKA) : holotype of Parapachydiscus stanislausensis ANDERson (1958, p. 227, pl.67, fig. 5, 5a), from loc. CAS. 29664, on Puerto Creek, Stanislaus County (Coll. A. BenNison); several specimens from loc. CAS. 29671, Little Salado Creek, Stanislaus County (Coll. BenNison \& William), loc. CAS. 29109, Salt Creek, Ortigalita Peak Quadrangle, Merced County (Coll. A. Bennison), and locs. CAS. 2362 and TM. 507 [=LSJU. 3345], Los Gatos Creek, Fresno County (Coll. M. B. Payne \& T. Matsumoto), all on west side of the San Joaquin Valley

P. neevesi WHITEAVES: holotype and paratype of Parapachydiscus bidwelli ANDERSON (1958, p. 228, pl. 51, fig. 5, 5a; pl. 54, fig. 1), from loc. CAS. 27838, Chico Creek, Butte County, east side of the Sacramento Valley

$$
\begin{array}{cl}
\text { Pachydiscus } & \text { (s.s.) cf. egertoni (FORBES) } \\
& \text { Text-figs. } 19,20
\end{array}
$$

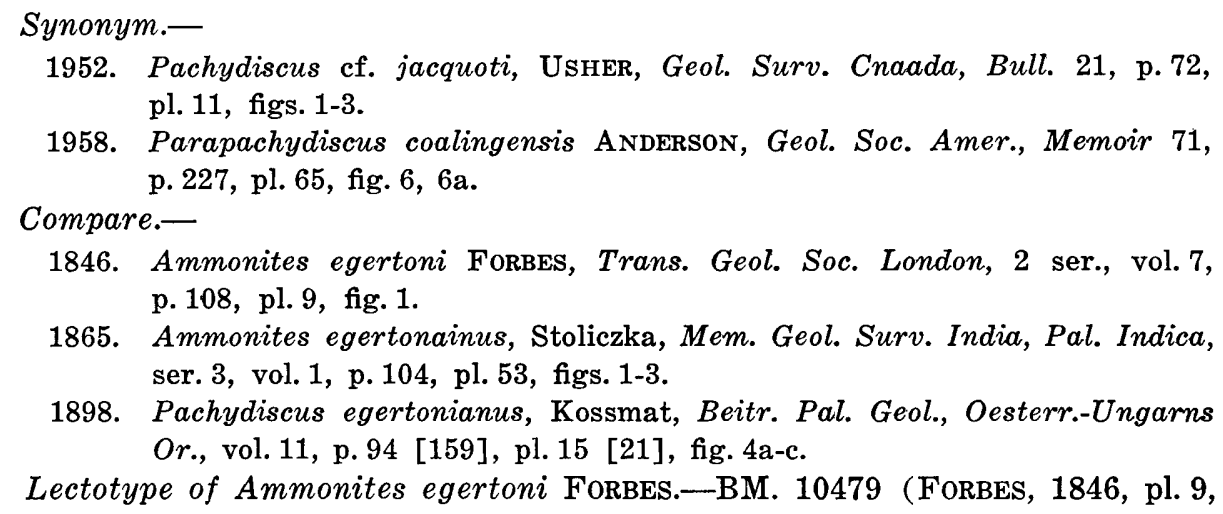
fig. 1) (Text-fig. 17 in this paper), from the Valudayur beds of Pondicherry, southern India, collected by KAYE and CUNLIFFE. There is one more fragmentary specimen in the collection of the British Museum, but it is not certain whether FORBES originally regarded it as another example of his Ammonites egertoni or its specific name was written subsequently on the label. On the assumption that the former is the case I designate the better preserved and illustrated specimen (BM. 10479) as the lectotype.

Material.-The following specimens from the West Coast are probably to be referred to $P$. egertoni (FORBES), although they were described under different specific names.

(1) The holotype of Parapachydiscus coalingensis ANDERSON (1958, p. 227, pl. 65, fig. 6, 6a) (Text-fig. 20 of this paper), from loc. CAS. 2362 (Coll. C. C. CHURCH)

(2) GSC. 5839, described as Pachydiscus sp. cf. P. jacquoti SeUnes by Usher (1952, p. 72, pl. 11, figs. 1-3), from Sucia Island, a plaster cast 
of which was at my disposal by courtesy of Dr. J. A. JELETZKY and Dr. D. L. JONES

In addition there are a few more Californian specimens from loc. UC. B-4149 (Text-fig. 19) (Coll. Paleont. Class of UC. and Monterey Peninsula College, 1957), locs. CAS. 29121, CAS. 29123 (Coll. A. BENNISON), and loc. CAS. 365 (Coll. R. E. DICKERSON).

$\begin{array}{lccrcc}\text { Measurements.- } & & & & \\ \quad \text { Specimen } & \text { Diameter } & \text { Height } & \text { Breadth (B/H) } & \text { Umbilicus (\%) } \\ \text { BM. 10479 } & 104.0 & 45.5 & 38.5(0.84) & 29.0(28) \\ \text { "coalingensis" } & \text { c. } 113 & 53 & 22 \times 2(0.83) & 28 & (24) \\ \text { "cf. jacquoti" } & 108 & 45 & 42(0.92) & 24 & (22) \\ \text { One from loc. } & \{- & 31.0 & 29.0(0.93) & \text { (costal) - } \\ \text { UC. B-4149 } & \{- & 17.0 & 17.0(1.0) & \end{array}$

Descriptive remarks.-Before entering on the description of the American specimens I ought to mention the relationship between Pachydiscus egertoni (FoRBES) and $P$. neubergicus (HAUER) (1858, p. 12, pro parte, pl. 2, figs. 1, 2, 3; not pl. 3, figs. 1, 2). As I previously pointed out (Matsumoto, 1936) the two species have been considered to be very closely allied or to be identical. Grossouvre (1894, 1908) held the opinion that they were specifically identical, but kept the name neubergicus, instead of the earlier egertoni. Kossmat (1898, p. 96) admitted some difference between them, but remarked that a variety of

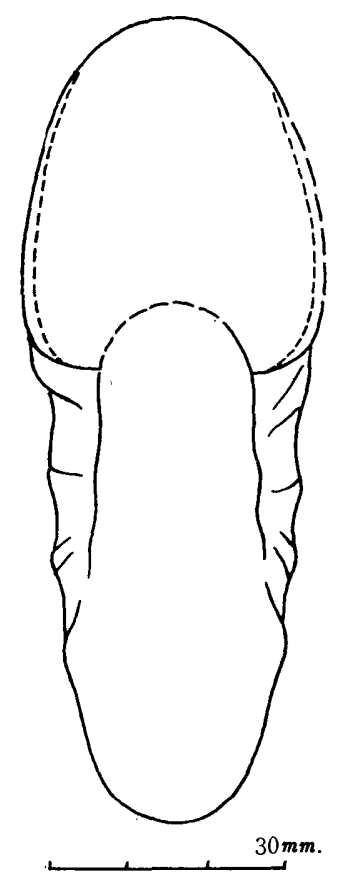

Fig. 17. Pachydiscus egertoni (ForBES). Outline of the frontal view. Lectotype, BM. 10479, from the Valudayur beds, Pondicherry, India (Coll. KAYE \& CUNLIFFE). Drawn by kind permission of the Keeper of Geology, British Museum (Natural History) (1954). 
P. neubergicus, as represented by "P. jacquoti SEUNES" (1890, p. 5, pl. 2, figs. 1-3) is hardly to be distinguished from $P$. egertoni.

I had an opportunity of studying the holotype of $P$. egertoni (FORBES) at the British Museum and a plaster cast of the original specimen of $P$. neubergicus (HAUER) (1858, pl. 2, figs. 1-3) at Stanford University. While the former is fairly well preserved, the latter is considerably crushed. Therefore a precise comparison between them is rather difficult. For $P$. neubergicus I have to depend much on descriptions and illustrations by the European authors. So far as the available evidence is concerned, I cannot find any significant difference between the two. The European species, $P$. neubergicus, seems to have finer ribs and slightly more compressed whorls than the Indian species, $P$. egertoni. This is very probably within the range of variation of a single species, and it might be possible, if ample material be studied, to separate the two as subspecies. Anyhow, for the purpose of describing the specimens from California and adjacent areas, I adopt the specific name $P$. egertoni (ForBEs, 1846), because its lectotype is better preserved, its type locality is geographically closer, and its date of publication is older than P. neubergicus (HAUER, 1858).

Now the several specimens before me, from the West Coast, themselves show variability, although they are most probably referred to $P$. egertoni (FORBES). The specimen which was described as Parapachydiscus coalingensis ANDERSON has the same type of suboval whorl-section (Text-fig. 20) which has nearly the same proportion of height and breadth as the holotype of P. egertoni. The configuration of its ribs and umbilical bullae is also very similar to that of the holotype, but the secondary ribs are more persistent than that. The similarly persistent secondary ribs can be recognized as a variation of $P$. neubergicus (compare pl. 38, fig. 3 with pl.30, fig. 4 of Grossouvre, 1894). The mid-venter of the Californian specimen is somewhat weathered, but the weakening of the ribs towards the mid-venter is evidently recognized as in the typical examples of $P$. egertoni and $P$. neubergicus. The slight weakening of the ribs at about the middle of the flank is also discernible.

The second specimen, GSC. No. 5839, was correctly compared with $P$. jacquoti SEUNES by Usher (1952, p. 72, pl. 11, figs. 1-3), but is, in my opinion, better called $P$. cf. egertoni, because $P$. jacquoti is nomenclatorially questionable, being probably a synonym of either $P$. neubergicus or $P$. egertoni. The specimen seems to represent a relatively inflated variant of $P$. egertoni. Its proportion of $\mathrm{B} / \mathrm{H}$ is slightly larger than that of the first specimen, but otherwise the two are very close to each other.

The third specimen, from loc. UC. B-4149, which is imperfectly preserved, has more numerous and narrower ribs than typical examples of $P$. egertoni, being fairly similar in this respect to Pachydiscus suciaensis (MEEK) (1861, p. $317 ; 1876$, p. 369 , pl. 5, fig. 2 , 2a, lectotype designated, in page 36 , USNM. 12396, from Komooks; not pl. 5, fig. 2b, 2c, another syntype, USNM. 1276, from Sucia Island, which is an eroded specimen of an entirely different species probably referable to Eupachydiscus haradai (JIMBO)), but its whorl-section is suboval 

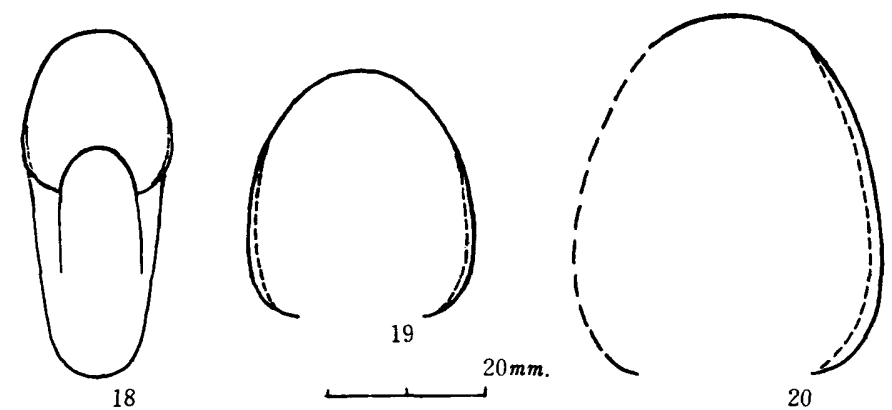

Figs. 18-20. Pachydiscus cf. egertoni (ForBES).

18. Outline of the front view. Holotype of Ammonites ganesa Forbes, BM. 10465, from the Valudayur beds of Pondicherry, India (Coll. KAYE \& Cunliffe). This is probably an immature Pachydiscus egertoni. Drawn by kind permission of the Keeper of Geology, British Museum (Natural History) (1954).

19. Whorl-section of a specimen from loc. UC. B-4149 on Ortigalita Creek, Merced County.

20. Whorl-section of another Californian example, a holotype of Parapachydiscus coalingensis ANDERson, from loc. CAS. 2362, northwest of Coalinga, Fresno County.

(Fig. 19), with convergent, instead of parallel, flanks, unlike P. suciaensis. This may be temporarily called Pachydiscus cf. egerrtoni (ForBES).

The original specimen of Ammonites suciaensis in GABB (1869, p. 133, pl. 21, figs. 11a, b), which was designated as the holotype of "Parapachydiscus diabloensis ANDERSON" (1958, p. 229, pl. 56, figs. 3, 4, 4a) is now preserved in the University of California (Berkeley), with Catal. No. UC. 12111. Its ribs are rather of intermediate narrowness between those of suciaensis and egertoni, and they are not so rectiradiate as in the typical examples of $P$. suciaensis (see also UsHer, 1952, p. 68, pl. 9, figs. 1-11; pl. 10, figs. 1-3; pl. 31, figs. 2, 3), but its whorl-section is flattened on the sides as in that species. It might be an extreme variant of $P$. egertoni, but is best designated $P$. cf. suciaensis (MEEK). For precise determination we need more specimens from the type locality, which is said in the Mt. Diablo area.

The fourth specimen, from loc. CAS. 29123, is poorly preserved. The fifth and sixth, from locs. CAS. 29121 and CAS. 365, are small, being close to Ammonites ganesa Forbes (1846, p. 103, pl.7, figs. 8a-c). Through the study of the holotype, BM. 10465 (Text-fig. 18), as well as these Californian examples, I am rather inclined to agree with Grossouve (1908) in regarding this small form as being an immature $P$. egertoni.

Occurrence.-The occurrence of $P$. cf. egertoni (FonBES) on the Pacific side of North America is noteworthy, although it is represented by a small number of imperfectly preserved specimens. Loc. CAS. 2362, "Pachydiscus silt" or "Ragged Valley shale" on Los Gatos Creek, near Coalinga, west side of the San Joaquin Valley, where Damesites hetonaiensis fresnoensis (ANDERsoN), Anagaudryceras mikobokense COLLIGNON, and G. (Vertebrites) kayei (FoRBES) are 
associated. Loc. UC. B-4149, on Ortigalita Creek, Merced County, west side of the San Joaquin Valley, where Anagaudryceras mikobokense (CollignoN), G. (Vertebrites) kayei (FORBES) and Glyptoxoceras subcompressum (FoRBES) are associated; loc. CAS. 29121, on the same Ortigalita Creek. Loc. CAS. 29123, in Pacheco Pass Quadrangle, west side of the San Joaquin Valley, where Exiteloceras (?) diabloense (ANDERSON) Solenoceras sp., and Nostoceras splendidus (SHUMARD) are associated. Loc. CAS. 365, Marysville or "Sutter" Buttes in the Sacramento Valley.

In India $P$. egertoni occurs in the Valudayur beds and in Japan I once saw a specimen of $P$. aff. egertoni in K. OTATUME's collection from the Upper Hetonaian of Hokkaido. While the species may have a certain stratigraphical range, it strongly suggests the Lower Maestrichtian near the boundary line with Campanian.

\section{Pachydiscus (s.s.) cf. subcompressus Matsumoto \\ Text-fig. 21}

Synonym.-

? 1958. Joaquinites fascicostatus Anderson, Geol. Soc. Amer., Memoir 71, p. 219, pl. 9, figs. 3, 3a, 4.

Compare.-

1954. Pachydiscus subcompressus Matsumoto, Cret. System Japanese Islands, Appendix, p. 287, pl. 10 [26], figs. 4a, b, 5a, b; pl. 11 [27], fig. 1a-c; pl. 12 [28], fig. 1a, b.

Types.-The species includes two subspecies, the holotype of each of which is as follows by original designation:

P. subcompressus subcompressus Matsumoto: GT. I-2815 (MATsumoto, 1954a, p. 287, pl. 10 [26], fig. 4, 4a), from loc. N105, bed Rdy 1, South Sakhalin

P. subcompressus obsoletus Matsumoto: GT. I-2827 (MATsumoto, 1954a, p. 289, pl. 10 [26], fig. 5a, b), bed Rdy, South Sakhalin

As the above specimens were secondarily compressed, paratypes were designated.

Material.-The Californian examples to be described here are more or less imperfectly preserved. They are the specimens from USGS. Mes. loc. 25218 (Text-fig. 21) (Coll. D. L. PECK et al), loc. LSJU. 3352 (Coll. Nomland), locs. CAS. 29118 (A. Bennison), CAS. 29602 (Coll. C. M. Cross ?), CAS. 29652 (Coll. A. BenNison), and CAS. 29653 (Coll. A. BenNison). The holotype of Joaquinites fascicostatus ANDERSON (1958, pl. 9, figs. 3, 3a, 4), from loc. CAS. 31593 (Coll. C. C. Church, G. D. HanNa, \& R. L. HewitT) probably belongs to this species.

\begin{tabular}{|c|c|c|c|c|}
\hline Specimen & Diameter & Height & Breadth $(\mathrm{B} / \mathrm{H})$ & Umbilicus (\%) \\
\hline Paratype (after & 152.5 & 67.6 & $44.0 \quad(0.65)$ & $36.3 \quad(23)$ \\
\hline MATSUMOTо, 1954a) & - & 46.9 & $34.2 \quad(0.73)$ & 一 \\
\hline
\end{tabular}




$\begin{array}{ccccccc}\text { Another paratype } & 129.5 & 58.5 & 39.5 & (0.67) & 29.0 & (22) \\ \text { ( } / \prime \quad \text { II) } & 86.7 & 40.8 & 29.2 & (0.71) & 20.3 & (22) \\ \text { One from USGS. 25218 } & 104.0 & 48.0 & 36.0 & (0.75) & 25.0 & (24) \\ \text { One from loc. LSJU. 3352 } & c .165 \text { (presumed) } & & & & & \\ \text { (deformed inner whorl) } & 75.0 & 40.5 & 21.0 & (-) & 17.5 & (22)\end{array}$

Descriptive remarks. - The Californian specimens under consideration are best comparable with $P$. subcompressus MATsumoto by the measured dimensions, relatively compressed whorls, numerous ventral ribs, weakened umbilical bullae at the end of the long ribs, and pattern of sutures.

The smoothish form as represented by the holotype of Joaquinites fascicostatum [recte fascicostatus] ANDERSON (1958, p. 219, pl.9, figs. 3, 3a, 4), the type-species of Joaquinites ANDERSON (1958, p. 218), is probably identical with $P$. subcompressus obsoletus Matsumoto (1954a, p. 289, pl. 10 [26], fig. 5a, b; pl. 11 [27], fig. 1a-c). Joaquinites must be, thus, the synonymy of Pachydiscus (s.s.).

Occurrence.-Loc. USGS. Mes. loc. 25218, unit 14 of Member V, Hornbrook formation, on the south side of the Klamath River, Siskiyou County (see PECK et al, 1956, p. 1980), where Metaplacenticeras pacificum (SмIтH) occurs abundantly. Loc. LSJU. 3352, Santa Monica Mountains; presumably belonging to the top member of the Cretaceous section in this area, where Metaplacenticeras is also known (see Popenoe, 1942). Other localities, CAS. 29118, CAS. 29602, CAS. 29652, CAS. 29653, and CAS. 31593, are not stratigraphically well located, but presumably in the relatively higher part of the Panoche group equivalent on the west side of the San Joaquin Valley.

In Japan and Sakhalin P. subcompressus is common in the Neohetonaian (probably Maestrichtian) but begins to appear in the upper part of the Paleohetonaian (probably Upper Campanian).

\section{Pachydiscus buckhami UsHeR}

Pl. 10, fig. 1a-c; Pl.11, figs. 1a-c, 2a, b; Pl. 17, fig. 3; Text-fig. 22

1864. Ammonites newberryanus, GABB (non MEEK) (pro parte), Pal. Calif.,

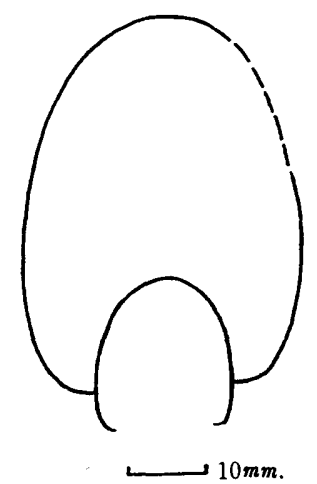

Fig. 21. Pachydiscus cf. subcompressus Matsumoto. Whorl-section of a specimen from USGS. Mes. loc. 25218, a bed with Metaplacenticeras pacificum in the Hornbrook formation. 
vol. 1, p. 61, pl. 27, fig. 199, 199b, 199c; pl. 28, fig. 199a.

1952. Pachydiscus buckhami Usher, Geol. Surv. Canada, Bull. 21, p. 89, pl. 23, figs. 1, 2, 3, 4, 5 .

1952. Pachydiscus elkhornensis Usher, Geol. Surv. Canada, Bull. 21, p.90, pl. 24, figs. 1, 2.

1958. Parapachydiscus gabbi Anderson, Geol. Soc. Amer., Memoir 71, p. 226, pl. 54, fig. 3, 3a, 3b, 3c.

1958. Parapachydiscus aff. gabbi Anderson, Geol. Soc. Amer., Memoir 71, p. 226, pl. 54, fig. 2, 2a.

1958. Parapachydiscus panochensis Anderson, Geol. Soc. Amer., Memoir 71, p. 226, pl. 67, figs. 1, 1a, 2.

Holotype.-GSC. 5947, from loc. 508, Trent River formation of Nanaimo group, Puntledge River, Vancouver Island, British Columbia, Canada [original designation by UsHeR, 1952]. Its last whorl is partly eroded and crushed.

Material.-By the courtesy of Dr. JELETZKY, plaster casts of Pachydiscus buckhami Usher (holotype, GSC. 5947, and a paratype, GSC. 10055) and Pachydiscus elkhornensis UsHeR (holotype, GSC. 10056) are before me. I have examined also the original specimen of GABB's Ammonites newberryanus (non MEEK) (1864, pl. 27, fig. 199, 199b, 199c; pl. 28, fig. 199a) (here figured, Pl. 10, fig. 1a-c; Text-fig. 22), from the Nanaimo group of Vancouver Island, in the Museum of Comparative Zoölogy at Harvard University. There are several other examples from the Nanaimo group in the collections of UC. and UCLA.

The Californian examples which I refer to the present species are as follows:

LSJU. 8534 (inner whorl and a half of the outer whorl, still septate) (Pl. 11, figs. 1, 2; Pl. 17, fig. 3) and LSJU. 8534 (deformed) from loc. LSJU. 2882 (Coll. R. E. Cook)

LSJU. 8536 (crushed, but showing characteristic ornament), from loc. LSJU. 2609 (Coll. R. E. CooK)

Two immature specimens described by ANDERSON (1958) as "Parapachydiscus aff. gabbi", from loc. CAS. 27838

A specimen described by ANDERSON (1958) as the "holotype of Parapachydiscus pachecoensis”, from loc. CAS. 28542, (Coll. TAFF \& Cross)

A specimen from loc. UCLA. 3647 (Coll. L. E. \& R. B. SAUL)

? A specimen from loc. CAS. 252a (Coll. Miss Davidson)

Measurements.-

\begin{tabular}{|c|c|c|c|c|c|}
\hline Specimen & Remarks & Diameter & Height & Breadth $(\mathrm{B} / \mathrm{H})$ & Umbilicus (\%) \\
\hline GSC. 5947 & (holotype)* & 90.0 & 38.7 & $45.9(1.18)$ & $21.6(24)$ \\
\hline GSC. 10054 & $($ paratype)* & 160.0 & 75.2 & $80.0(1.06)$ & $35.2(22)$ \\
\hline GSC. 10056 & (elkhornensis)* & $\left\{\begin{array}{l}89.0 \\
30.0\end{array}\right.$ & $\begin{array}{l}42.7 \\
15.3\end{array}$ & $\begin{array}{l}41.8(0.98) \\
15.3(1.0)\end{array}$ & $\begin{array}{r}20.5(23) \\
6.0(20)\end{array}$ \\
\hline MCZ. & (holotype of $g a b b i$ ) & 144.0 & 68.0 & $67.0(0.98)$ & $32.0(22)$ \\
\hline$" \prime$ & ( $1 / 2$ vol. earlier) & - & 44.0 & $45.5(1.03)$ & 21.2 \\
\hline CAS. & ("aff. gabbi") & - & 15.9 & $18.3(1.15)$ & - \\
\hline CAS. & ("aff. gabbi") & 16.5 & 8.2 & $9.8(1.2)$ & $3.7(22)$ \\
\hline LSJU. 8534 & & c. $\begin{array}{r}152.5 \\
\overline{63.5}\end{array}$ & $\begin{array}{l}67.5 \\
57.3 \\
29.0\end{array}$ & $\begin{array}{l}64.0(0.95) \\
52.4(0.91) \\
28.3(0.97)\end{array}$ & $\begin{array}{l}\text { c. } 36.0(23) \\
-\end{array}$ \\
\hline LSJU. 8536 & & 36.2 & 16.1 & $17.6(1.09)$ & \\
\hline
\end{tabular}




\begin{tabular}{|c|c|c|c|c|c|}
\hline CAS. & $\left\{\begin{array}{c}(\text { holotype of } \\
\text { pachecoensis })\end{array}\right\}$ & - & 65.3 & $65.5(1.10)$ & - \\
\hline One from & loc. UC. 2208 & - & 30.0 & $30.0(1.00)$ & - \\
\hline Another & $\prime \prime \prime \prime$ & - & 38.5 & $37.5(0.97)$ & - \\
\hline UCLA. 364 & 7 (diam. restored) & c. 52 & 22.0 & $23.5(1.07)$ & c. 14 \\
\hline$\prime \prime$ & ( $1 / 4$ vol. earlier) & - & 19.5 & $21.8(1.11)$ & - \\
\hline \multicolumn{6}{|c|}{ For comparison } \\
\hline GSC. 5853 & (P. neevesi)* & 196.0 & 89.0 & $71.9(0.80)$ & $39.2(20)$ \\
\hline GSC. 5850 & $(P . \text { ootacodensis })^{*}$ & 126.5 & 64.0 & $63.0(0.98)$ & $29.0(23)$ \\
\hline GT. I-102 & (A. subtililobatus) & 118.0 & 58.0 & $70.0(1.20)$ & $33 \quad(28)$ \\
\hline \multirow[t]{2}{*}{ CAS. } & (holotype of bidwelli) & 151.0 & 72.5 & 47.3 (deform) & $32.7(21)$ \\
\hline & $(1 / 2$ vol. earlier) & - & 50.6 & $36.0(0.71)$ & - \\
\hline$\prime \prime$ & (inner whorl) & - & 16.5 & $14.5(0.87)$ & - \\
\hline$\prime \prime$ & (paratype of bidwelli) & 125.0 & 60.0 & $45.6(0.76)$ & $28.7(23)$ \\
\hline$\prime \prime$ & $(1 / 2$ vol. earlier) & - & 39.3 & $31.3(0.79)$ & - \\
\hline
\end{tabular}

Diagnosis.-The shell is fairly involute, fairly narrowly umbilicate, rapid in growth, and may reach a large size. The whorl is slightly broader than high in the earlier growth-stages and slightly higher than broad in the later growthstages; the proportion of height and breadth varies also by individuals. The umbilicus is moderately deep, being surrounded by a steep and almost vertical wall and an abruptly rounded shoulder; the flank is gently convex, with the maximum inflation somewhat below its middle; the venter is moderately arched.

The ribs are narrow but distinct, separated by interspaces which are much wider than the ribs, although the intervals vary between and also within individuals. The ribs are of unequal strength and length. The relatively more elevated and longer ones have bullate tubercles near the umbilical margin. Many of the tubercles are so indistinct, especially on the internal mould, that they may be better called slight thickenings of the ribs at the umbilical shoulder. The distribution of the major ribs is irregular, some of them being very distant but others fairly close to one another. The minor ribs arise at different points between the umbilical margin and mid-flank; they are not always of equal intensity. In addition to them, faint riblets and striae may be discernible on the interspaces. Generally the ornament is more distinct on the surface of the outer layer of the shell than on the inner layer or on the internal mould. The ribs incline gently forward on the flank, sometimes showing slight flexuosity; they are moderately projected on the venter.

The suture is finely and deeply incised, resulting in extremely narrow stems of the lobes. The pattern is the same as that of many Pachydiscus and Anapachydiscus.

Remarks.-The holotypes of Pachydiscus buckhami UsHer and P. elkhornensis UsHeR both have the above-described diagnosis. The distinction between them, which USHER mentioned, is so slight that it can be ignored as variation within the same species. Secondary deformation may have also given rise to apparent difference.

The best preserved example of the present species is one of GABB's illustrated specimens of Ammonites newberryanus (non MEEK) (1864, pl. 27, fig. 199, 199b, 


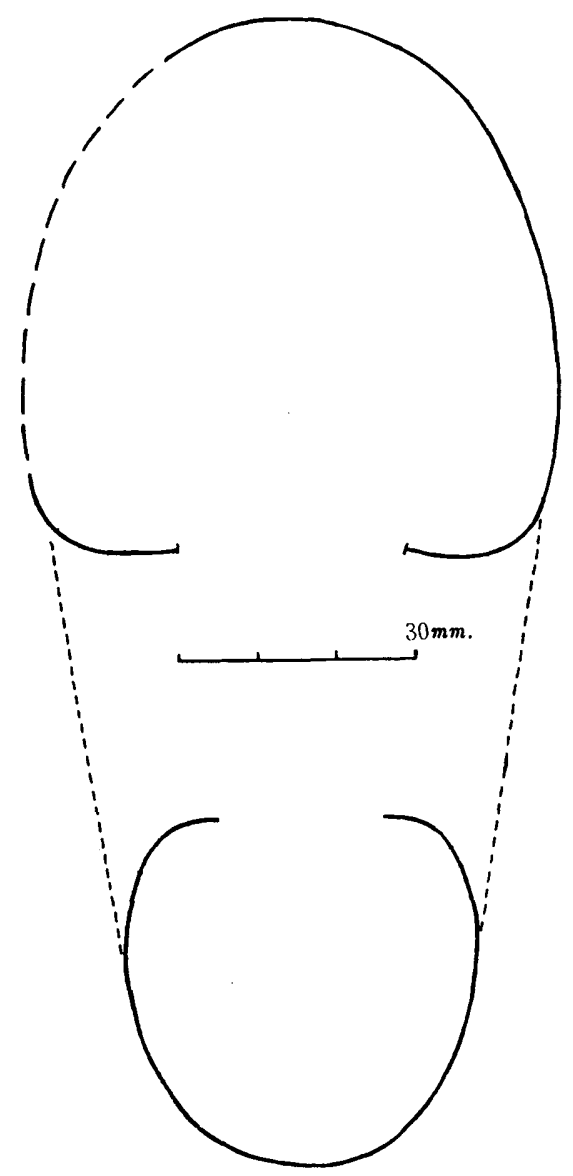

Fig. 22. Pachydiscus buckhami Usher. Cross section of an example in WHITNEY's collection at MCZ, Harvard University. This is GABB's hypotype of Ammonites newberryanus (non MEEK). See Pl. 10, fig. la-c for other views.

199c; pl. 28, fig. 199a) (Pl. 10, fig. 1a-c in this paper), which has unnecessarily received another specific name, Parapachydiscus gabbi ANDERSON (1958, p. 226). It has the same type of ribbing as the holotype of $P$. buckhami UsHeR, while its proportion of worl-height and breadth is just the same as that of the holotype of "P. elkhornensis UsHeR".

In summation, the specific names $P$. elkhornensis Usher and $P$. gabbi ANDERSON fall into the synonymy of $P$. buckhami UsHer.

The Californian examples similarly show some variability but have good specific diagnosis. One of the three specimens in the collections of Stanford University, from locs. LSJU. 2882 and LSJU. 2609 (where Submortoniceras chicoense (TRASK) and Baculites chicoensis TRASK occur) (PI. 11, figs. 1, 2; Pl. 17, fig. 3) is slightly higher than broad, but has relatively frequent ribs on the outer whorl. Another shows distant, narrow, elevated ribs. Two small, 
ovbiously immature, specimens from loc. CAS. 27838 (where again S. chicoense and $B$. chicoensis occur), which were called "Parapachydiscus aff. gabbi ANDERsoN" (1958, p. 226, pl. 54, fig. 2, 2a), are as inflated as the holotype of $P$. buckhami USHER, but one of them has as widely spaced ribs as "the holotype of $P$. elkhornensis UsHeR". ANDERSON proposed another new specific name, "Parapachydiscus panochensis ANDERSON” (1958, p. 226, pl. 67, figs. 1, 1a, 2), for a specimen from loc. CAS. 28542, which is stratigraphically higher than the localities (TM. 14 and TM. 11) of Baculites capensis WooDs, and, accordingly correspond approximately to the upper part of the type Chico formation, although Baculites chicoensis Trask has not yet been discovered there. This is another example of the present species, in which the ribs are moderately strong on some parts, but weak on other parts. It reaches a large size. Another specimen, labelled as $P$. aff. panochensis, from loc. CAS. 252 (Santiago Canyon), is probably referable to the present species.

Now Pachydiscus buckhami UsHer, here emended, is interesting in that it is morphologically intermediate between Anapachydiscus subtililobatus (Jімво) (1894, p. 30 [176], pl. 4 [20], fig. 2, 2a, 2b) and Pachydiscus ootacodensis (STOLICZKA). It is closely allied to the last species in shell-form and mode of ribbing, as UsHeR (1952) has already pointed out. The distinction is the complete absence of umbilical tubercles and the less elevated ribs in the latter. The tendency to weakening of the umbilical tubercles is already found in $P$. buckhami Usher. The Japanese species, A. subtililobatus (JImBo), likewise has much suppressed tubercles and fairly elevated, narrow ribs. It is distinctly more inflated and has more numerous ribs than $P$. buckhami UsHeR.

Typical representatives of Anapachydiscus are much more inflated than these species under consideration, while those of Pachydiscus (s.s.) are more compressed and have a peculiar ornament in which numerous ventral ribs and a small number of umbilical bullae are differentiated. Therefore, P. buckhami Usher is not a typical example of Pachydiscus (s.s.). In Europe and other parts of the world, there are several species which are somewhat intermediate between Anapachydiscus and Pachydiscus. They have been mostly assigned to Pachydiscus. Similarly the present species is referable to Pachydiscus.

On the West Coast of America, Pachydiscus neevesi Whiteaves (1903, p. 342 , pl. 47, fig. 1 ; text-fig. 21 ; UsHeR, 1952, p. 87, pl. 22, figs. 1, 2; pl. 31, fig. 7) should be brought into comparison with the present species. There are two Californian specimens which are undoubtedly referable to WHITEAVEs' species. Anderson proposed for them a new specific name, "Parapachydiscus bidwelli ANDERSON" (1958, p. 228, pl. 54, fig. 1; pl. 51, fig. 5, 5a) (Text-fig. 23 of this paper), which is obviously a synonym of $P$. neevesi WHITEAVEs, as IMLAY has pointed out (personal comm. Oct. 1957). They were obtained from the same locality (CAS. 27838) as the above mentioned " $P$. aff. gabbi ANDERson". $P$. neevesi WHITEAvEs belongs to the same group as $P$. buckhami UsHer and $P$. ootacodensis (STOLICZKA); the resemblance is so close that someone might consider it as an extreme variant of $P$. buckhami (in which case buckhami 


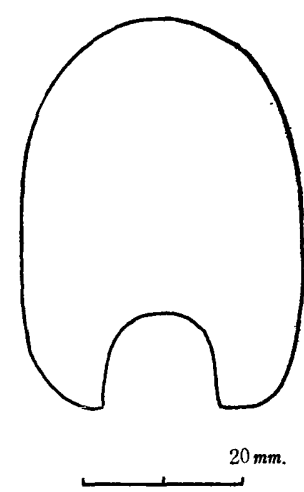

Fig. 23. Pachydiscus neevesi Whiteaves. Whorl-section of a Californian example [=holotype of Parapachydiscus bidwelli ANDERSON], from loc. CAS. 27838, Chico Creek, Butte County.

would be nomenclatorially preoccupied by neevesi), but complete gradation has not been traced between them. Therefore I separate them as different species. In British Columbia P. neevesi occurs at a higher level than $P$. buckhami. The former is distinguished from the latter by much compressed, high whorls, a narrowly rounded venter, parallel, flattened flanks, and numerous, weak ribs. The narrow but elevated ribs, like that of $P$. buckhami, are only rarely discernible on the inner whorl of one of the Californian examples.

Occurrence.-Sporadic both in Vancouver Island and California. The Californian representatives were obtained from locs. LSJU. 2882, LSJU. 2609, UCLA. 3647 and CAS. 27838, associated with Submortoniceras chicoense (TRASK) and Baculites chicoensis TRAsK, upper part of the Chico formation in the type area, Chico Creek, east side of the Sacramento Valley; loc. CAS. 28542, upper part of the Upper Marlife formation, Panoche group, in its type area, Panoche Hills, west side of the San Joaquin Valley. A comparable specimen came from loc. CAS. 252a, Santiago Canyon, Orange County.

According to UsHeR (1952), P. buckhami UsHer occurs in the Trent River and Haslam formations of the Nanaimo group of Vancouver Island, and " $P$. elkhornensis UsHeR" (now synonymized with $P$. buckhami) in the Haslam formation of Vancouver Island, British Columbia.

I have not recognized an unmistakable example of the present species in the Cretaceous of Japan. The allied species, Anapachydiscus subtililobatus (JIмBo), which is again rare, is to be referred to the Campanian.

\section{Genus Canadoceras SPATH, 1922}

Type-species.-Ammonites newberryanum MEEK, 1857.

Generic diagnosis.-The whorl is relatively compressed, nearly as high as broad or higher than broad, height increasing more rapidly with growth. Its involution is moderate to rather little; the umbilicus is, accordingly, sometimes fairly narrow (20-29 per cent of diameter), and sometimes of moderate size (30- 
38 percent). The flank is gently inflated or rather flattened; the venter is moderately or narrowly rounded. The shell is ornamented with numerous, moderately strong ribs, which cross the venter with more or less forward curvature. They are of unequal length, but mostly start at or near the umbilical margin. The longer ribs have umbilical tubercles. The periodic constriction is characteristic of the genus; it is normally well-marked in the middle growthstage, but may be less so on the adult body whorl. The constriction is as a rule associated with longer and stronger rib, which has a prominent tubercle at the umbilical shoulder. On the adult body whorl the ribs and tubercles tend to be weakened. The suture is of normal Pachydiscus type, deeply and finely incised, with narrow stems of lobes. In the later growth-stages the first lateral lobe (L) is somewhat longer than the external lobe (E). The shell usually reaches a large size.

Remarks.-The ontogenetic development and relation to other genera have already been given in my previous paper (1954a, Cret. System Japan. Isl., p. 291-295).

In the Upper Cretaceous of California I have recognized the following species of Canadoceras:

(1) C. newberryanum (MEEK)

(2) C. yokoyamai (JIMBo)

(3) C. mysticum MATSUMoto

(4) C. sp. nov. (?) aff. C. hoepeni CollignoN

The last species is now being studied by Dr. E. L. PACKard and Dr. S. W. MULLER, so it is left undescribed in this paper. It came from loc. LSJU. 3355, an isolated Cretaceous outcrop at Pape Place, Mill Creek, Tehama Country, east side of the Sacramento Valley. It is, in my preliminary observation, closely allied to C. hoepeni Collignon (1952, p. 47, pl. 12, fig. 1, 1a, 1b; 1955, p. 47, pl. 12, fig. 1, 1a, 1b) from the Campanian of Madagascar, and is peculiar in that the constrictions are shallow and indistinct even on the inner whorls.

The geological age of all the four species is referable to the Campanian like that of the genus in other parts of the world.

\section{Canadoceras newberryanum (MEEK)}

Pl. 14, fig. 2a, b

1857. Ammonites newberryanus MeEk, Trans. Albany Inst., vol. 4, p. 47.

? 1869. Ammonites fraternus GABB, Pal. Calif., vol.2, p.137, pl.23, fig. 15, $15 \mathrm{a}, 15 \mathrm{~b}$.

1876. Ammonites newberryanus, MEeK, Bull. U. S. Geol. Geogr. Surv. Terr., vol. 2 , no. 4 , p. 367 , pl. 4 , fig. 3 , 3a 3 b.

1879. Ammonites newberryanus, WhITEAVES (pro parte), Mesozoic Fossil, vol. 1, pt. 2, p. 109.

1902. Pachydiscus newberryanus, ANDERSON (pro parte), Proc. Cal. Acad. Sci., 3rd ser., vol. 2, no. 1, p. 102.

1903. Pachydiscus newberryanus, WhIteAves, Mesozoic Fossils, vol.1, pt.5, p. 348 . 
1922. Canadoceras newberryanum, SPAтH, Trans. Roy. Soc. S. Africa, vol.10, pt. 3, p. 125, pl. 7, fig. 5; pl. 8, fig. 4 .

1952. Pachydiscus (Canadoceras) newberryanus, Usher, Geol. Surv. Canada, Bull. 21, p. 65, pl. 6, figs. 4-7; pl. 7, fig. 1 ; pl. 8, figs. 1, 2; pl. 31, fig. 4 .

1958. Canadoceras georgianum, ANDERSON, Geol. Soc. Amer., Memoir 71, p. 234, pl. 32, fig. 3, 3a.

1958. Canadoceras newberryanum, ANDerson, Geol. Soc. Amer., Memoir 71, p. 232, pl. 42, figs. 1, 1a, 1b, 2.

1958. Canadoceras celeste ANDERSon, Geol. Soc. Amer., Memoir 71, p.234, pl. 42, fig. 3, 3a.

Holotype.-USNM. 12394 from "Komooks, Vancouver Island".

Material.-Californian examples of the present species are a specimen, LSJU. 8533 (PI. 14, fig. 2a, b), from loc. LSJU. 2883 (Coll. R. E. CooK) ; two specimens from USGS. Mes. locs. 23009 and 20146; UC. 14971, probably one of the specimens which ANDERSON (1902, p. 102) described as Pachydiscus newberryanus, which is secondarily compressed but well comparable with C. newberryanum, another comparable specimen from loc. UC. A-6588, Pence's ranch; holotype of Canadoceras celeste (ANDERSON) (1958, p. 234, pl. 42, fig. 3, 3a), from loc. CAS. 31208, Yolo County (Coll. F. M. ANDERson) ; several comparable specimens from loc. LSJU. 3169 (Coll. J. M. KIRBY).

$\begin{array}{llcccr}\begin{array}{c}\text { Measurements. } \\ \text { Specimen }\end{array} & \text { Remarks } & \text { Diameter } & \text { Height } & \text { Breadth (B/H) } & \text { Umbilicus (\%) } \\ \text { USNM. 12394 } & \text { (holotype) } & 57.0 & 24.8 & c .24 .8(1.0) & 17.8(31) \\ \text { BM. C } 23215 & \text { ("genotype") } & 145.0 & 66.5 & 53.0(0.79) & 38.3(26) \\ \text { GSC. 10031 } & \text { [after USHER] } & 150.0 & 66.0 & 52.5(0.79) & 37.5(25) \\ \text { LSJU. } & \text { (holotype of } & 135.2 & 56.0 & 44.2(0.79) & 38.2(28) \\ \text { LSJU. 8533 } & & 109.0 & 48.0 & 42.5(0.88) & 31.7(29) \\ \text { "georgianum") } & \text { (1/2 vol. earlier) } & - & 32.5 & 30.8(0.94) & - \\ \text { USNM. from USGS. 20146 } & 94.0 & 40.0 & 36.0(1.9) & 28.0(29)\end{array}$

Descriptive remarks.-UsHer (1952) has given a full description of the present species. Although the holotype is evidently immature, UsHeR has presented examples of various growth-stages. The specimen preserved in the British Museum, BM. C23215, which I examined during my visit there, matches in many respects another example, GSC. 10031, of USHER (1952, pl. 7, fig. 1, pl. 8, figs. 1,2). Thus the species has been well defined on the basis of the specimens from the Nanaimo group.

One of the specimens from Sucia Island, now preserved at Stanford University, has recently received a new name, Canadoceras georgianum ANDERSON (1958, p. 234, pl. 32, fig. 3, 3a). Although the specimen is somewhat deformed, it is a good example of C. newberryanum (MEEK), as ANDERSoN once (1902, p. 102) correctly thought.

In the Cretaceous of California, the species does not seem to be so prolific as in the Nanaimo group. I have recognized several examples as listed above.

In addition to them, the original specimen of Ammonites fraternus GABB (1869, p. 139, pl. 23, fig. 15, 15a, 15b), from "Benicia", Sorano County, now preserved in the Museum of the Academy of Natural Sciences of Philadelphia, 
may be synonymized with the present species. In fact the whorl-section restored by GABB (1869, pl. 23, fig. 15a) indicates the proportion of breadth and height $(\mathrm{b} / \mathrm{h}=1.08)$ quite similar to that of the young whorl of $C$. newberryanum. Actually the specimen is partly covered by rock matrix. Therefore its dimensions cannot be accurately measured. Possibly it could be a young shell of Canadoseras yokoyamai (JiмBo). If it should be proved to be so, Jiмвo's specific name should be synonymized with $C$. fraternum (GABB). From this poorly preserved GABB's specimens, we cannot be certain and better preserved topotypes would be essential to settle the problem of nomenclature. But from the too broadly indicated locality "Benicia", it is rather difficult to know where the type locality of GABB's species is.

In Japan and Sakhalin there is no typical example of Canadoceras newberryanum (MEFK), but there occurs characteristically in the zone of Inoceramus schmidti C. kossmati (YABE MS.) MATSUMото (1954a, p. 295, pl. 13, [29], fig. $1 \mathrm{a}, \mathrm{b}$; pl. 14 [30], figs. 1, 2; pl. 15 [31], fig. 1; pl. 16 [32], figs. 1, 2a, b, 3a, b, $4 \mathrm{a}, \mathrm{b}$; text-figs. 18-25 [64-71] ; 27 [73]). As I have already remarked, these two species are closely allied. On examining a number of specimens from the West North America, I have noticed that there is a certain extent of variation in C. newberryanum (MEEK) itself, as UsHeR (1952, p. 84) has mentioned. Similarly C. kossmati Matsumoto is variable to some extent. Therefore, so far as the morphological characters of shells are concerned, the variations of the two species may overlap each other. However, on average C. newberryanum (MEEK) is somewhat more compressed and has a more narrowly arched venter than C. kossmati Matsumoto. The distinction is better discernible in the late growthstage. Anyhow the difference is so small, that subspecific separation might be desirable. The two species are nearly contemporary at least partly in their geological ranges. Therefore geographical subspecies could be considered. For a decision of the situation, statistical study may be required and the material from Alaska will be certainly important. I have seen some examples from Alaska, which are again associated with Inoceramus schmidti MICHAEL. However, the number of well-preserved specimens is not large enough to examine this question. At least some of them are better referable to C. kossmati MATSUмото than to $C$. newberryanum (MEEK).

Occurrence.-The type locality, "Komooks, Vancouver Island", seems to be actually in the Nanaimo district, as indicated by UsHer (1952, p. 68). I have seen several examples from Sucia Island, San Juan County, Washington. Occurrence of the Californian specimens which I have examined are loc. LSJU. 2883, upper part of the type Chico formation, on Chico Creek, Butte County, east side of the Sacramento Valley; USGS. Mes. locs. 23009 and 22146, from the same Chico Creek (precise position uncertain) ; loc. UC. A-6588 and another in Pence's ranch, Butte County; loc. CAS. 31208, probably Forbes formation, Yolo County; loc. LSJU. 3169, basal part of Forbes formation, Sand Creek in Colusa County. In the last locality this species is associated with Patagiosites arbucklensis (ANDERSON) and Inoceramus schmidti MICHAEL. 


\section{Canadoceras yokoyamai (ЈІмво)}

Pl. 12, fig. 1a-c; Pl.13, figs. 1a-c, 2;

Pl. 14, fig. 1a, b; Pl. 15, fig. 1a-c

1894. Pachydiscus yokoyamai Jiмвo, Pal. Abh., Bd. 6 [N. F. 2], p. 31 [177], pI. 2 [18], fig. 3, 3a, 3b.

? 1903. Pachydiscus multisulcatus Whiteaves, Mesozoic Fossils, vol. 1, pt. 5, p. 349 , text-fig. 50 ; pl. 50 .

? 1952. Pachydiscus multisulcatus, UsHer, Geol. Surv. Canada, Bull. 21, p. 81, pl. 16, figs. 1-4; pl. 31, fig. 8.

1954. Canadoceras yokoyamai, MATsumoto, Cret. System Japanese Islands, Appendix, p. 302, pl. 13 [29], fig. 2a, b; pl. 17 [33], figs. 1a, b, 2; textfig.26 [72].

1954. Canadoceras aff. kossmati MATSUMoto (pro parte), Cret. System Japanese Islands, Appendix, p. 296, pl. 20 [36], fig. 4a, b.

1958. Canadoceras fraternum, ANDERSON (non GABB), Geol. Soc. Amer., Memoir 71 , p. 233, pl. 50, fig. 1 .

Holotype.-GT. I-103 from "Tsiptaushibets, a branch of the Tumbets, Kitami province, Hokkaido". A number of other examples from the Campanian of Hokkaido and Sakhalin have been shown in my paper (1954a).

Material.-The Californian examples of the present species, which I have examined, are as follows:

UC. 14938 from loc. UC. 2701, and another from loc. UC. 2699, Chico Creek, Butte County (no record of collectors)

LSJU. 8532 (Pl. 12, fig. 1a-c) from loc. LSJU. 2609, Chico Creek, Butte County (Coll. R. E. Cook)

LSJU. 8528 (Pl. 13, figs. 1a-c, 2), 8529, 8530, 8531A, and 8531B (Pl. 14, fig. 1a, b) from loc. LSJU. 3355, Mill Creek, Tehama County (Coll. S. W. MULLER)

GK. H7004 from loc. TM. 1011 [=LSJU. 3300], Chico Creek, Butte County (Coll. T. Matsumoto and S. Chuber)

A young specimen, UCLA. 28843 (Pl. 15, fig. 1a-c), from loc. UCLA. 3637, Chico Creek, Butte County (Coll. L. E. \& R. B. SAUL)

A comparable specimen from loc. CIT. 1053, Orange County (Coll. W. P. POPENOE)

Measurements.-

\begin{tabular}{|c|c|c|c|c|}
\hline Remarks & Diameter & Height & Breadth $(B / H)$ & Umbilicus (\%) \\
\hline US. $14938\left\{\begin{array}{l}\text { (last whorl }) \\
(1 / 2 \text { whorl earlier })\end{array}\right.$ & 203.0 & $\begin{array}{l}85.5 \\
47.3\end{array}$ & $\begin{array}{l}77.5(0.90) \\
43.7(0.92)\end{array}$ & $60.7(30)$ \\
\hline LSJU. $8532\left\{\begin{array}{l}(\text { at the last septum }) \\
(1 / 2 \text { whorl earlier }) \\
(1 \text { whorl earlier })\end{array}\right.$ & $\begin{array}{l}\text { c. } 160 \\
\quad 115.0 \\
\text { c. } 85\end{array}$ & $\begin{array}{l}63.0 \\
44.0 \\
34.6\end{array}$ & $\begin{array}{l}62.0(0.98) \\
44.5(1.01) \\
35.5(1.02)\end{array}$ & $\begin{array}{l}49.0(31) \\
37.8(32) \\
28.4(33)\end{array}$ \\
\hline LSJU. $8528\left\{\begin{array}{l}\text { (at the illustrated } \\
\text { suture) }\end{array}\right.$ & 120.0 & 52.4 & $53.5(1.02)$ & $31.8(26)$ \\
\hline$(1 / 2$ whorl earlier $)$ & - & 37.8 & $40.9(1.08)$ & - \\
\hline LSJU. $8529\left\{\begin{array}{l}(\text { last whorl }) \\
(1 / 2 \text { whorl earlier })\end{array}\right.$ & c. 105 & $\begin{array}{l}46.0 \\
33.6\end{array}$ & $\begin{array}{l}46.0(1.0) \\
37.4(1.11)\end{array}$ & - \\
\hline LSJU. 8531B (undeformed part) & 75. & 34.5 & $34.5(1.0)$ & $20.2(27)$ \\
\hline GK. H 7004 (immature) & 35.5 & 14.0 & $16.0(1.14)$ & $12.5(35)$ \\
\hline
\end{tabular}




$\begin{array}{cllll}\text { One from loc. UC. } 2699 & 90.5 & 38.0 & - & 27.0(30) \\ \text { " } \quad \text { (slightly earlier) } & - & 34.7 & 34.7(1.00) & - \\ \text { UCLA. 28843 (immature) } & 33.0 & 13.8 & 16.2(1.17) & 11.3(34)\end{array}$

Diagnosis.-The whorl is relatively thick, somewhat broader than high in the earlier growth-stages, and nearly as broad as high in the later. The flank is convex and the venter is moderately rounded. The umbilicus is fairly narrow and fairly deep, with a steep umbilical wall and a rounded shoulder. The maximum breadth of the whorl is at or slightly above the umbilical shoulder.

The ribs are relatively coarse and strong, as compared with other species of Canadoceras, becoming, however, weak on the body whorl of the full grown shell. They are separated by interspaces as broad as or slightly broader than themselves. They are of unequal length, but even the shorter ribs arise slightly above the umbilical shoulder. Some of the shorter ribs branch from the longer ones, and others are intercalated. The periodic, long and strong ribs are provided with prominent tubercles at the umbilical shoulder and are associated with constrictions on the internal mould, but tuberculated long ribs without accompanying constrictions may be found. The tubercles become weak and bullate on the outer whorl. The ribs are prorsiradiate, gently arcuate on the flank, concave anteriorly, and show a projection of moderate intensity on the venter.

There is no significant difference in suture among the species of Canadoceras.

The shell sometimes reaches a large size. An example from California has the last suture at a diameter of about $230 \mathrm{~mm}$.

Remarks.-Almost all the specimens from California listed above match so well the Japanese examples of Caradoceras yokoyamai (JIMBO), that I am confident about the identity of species. A few specimens from Chico Creek have, however, a relatively wide umbilicus as compared with the usual examples. They exhibit otherwise the diagnostic features of the present species, and are best referred to it. If the widely umbilicate form were proved to occur slightly higher (or lower) level than the normal one, it might be separated subspecifically. So far as the available material is concerned, such a situation is not likely to happen. In Japan, Sakhalin, and Alaska (in the collection of Paleontological Laboratory of Shell Oil Co. at Seattle) there are examples of widely umbilicate Canadoceras multicostatum Matsumoto (1954a, p. 304, pl. 18 [34], figs. 1a, b, c, 2 ; text-fig. 28 [74]), but that species is clearly distinguished from C. yokoyamai (JIMBO) by its more compressed whorls and more numerous, more crowded, and finer ribs.

The present species was once regarded by SPATH (1922, p. 124) as a probable example of Nowakites. From the descriptions and illustrations of the species of Nowakites, from the Lower Senonian of Europe, I hesitate to give here clear distinction between Nowakites and Canadoceras. The diagnosis of Nowakites recently written by CoLlignoN (1955, p. 13) can well be also applied to some species of Canadoceras. Frequent umbilical tubercles may characterize Nowakites. In addition, we could expect distinction in sutures and in the size of the adult shell. However, the suture of the holotype of the type-species of Nowakites, Pachydiscus carezi Grossouvre (1894 [1893], p. 190, pl. 25, fig. 3), is not known. 
Anyhow, C. yokoyamai (Jimbo) is so intimately allied to C. kossmati Matsumoto and also C. newberryanum (MEEK), the type-species of Canadoceras, that I think it reasonable and natural to refer this species to Canadoceras, which genus is better defined and better known (see Matsumoto, 1954a, p. 290) than Nowakites.

The distinction of C. yokoyamai (JIMBo) from C. newberryanum (MEEK) and also from C. kossmati (MAтsumoto) lies in its broader whorl and coarser ribs. In this respect C. yokoyamai (JIMBo) is closer to C. multisulcatum (WHITEAVES) (1903, p. 349, pl. 50; UsHeR, 1952, p. 81, pl. 16, figs. 1-4; pl. 31, fig. 8), as I mentioned previously (1954 [1953], p. 304). On seeing the examples from California, with some variability, I am rather inclined to doubt the specific distinction between C. yokoyamai (Jimbo) and C. multisulcatum (WhITEAVES). WhiteAVES' illustrated specimen of Pachydiscus multisulcatus (1903, text-fig. 24 and pl. 50), GSC. 5856, which is here designated as lectotype (not holotype, despite UsHeR's indication [1952, p. 84], since it is one of the syntypic specimens), has rather semielliptical whorl section just like the typical examples of C. yokoyamai (ЈIмBo). Minor difference in ribbing may not be significant, since the species is variable in that point, as UsHer has mentioned (1952, p. 84). Some of the Canadian specimens have a wide umbilicus, just as some of the Californian ones have. One of the Japanese examples, GK. H3540, which came from the bed below the level of unmistakable C. kossmati Matsumoto, was considered by myself (1954 [1953], p. 296) to be possibly referable to C. multisulcatum (Whiteaves), although it was listed and illustrated temporarily as C. aff. kossmati Matsumoto (1954a, p. 296, pl. 20 [36], fig. 4, 4a). This is, in my present knowledge, better regarded as being within the variation of $C$. yokoyamai (JiмBo).

From all the above observation, C. multisulcatum (WHITEAVES) (1903) very probably falls in the synonymy of C. yoloyamai (ЈімBo) (1894). However, I suspend a final conclusion until I get an opportunity of studying the type specimens of the former.

C. yokoyamai (JІмво) might be sometimes misidentified with Eupachydiscus haradai (JIMBO), especially with the relatively less inflated representative of that species on the West Coast. In the former there is a decrease in the intensity of ornament on the whorl of the later growth-stages, while the latter shows an increase of ornament on the mature whorls. A periodic constriction is another criterion.

Occurrence.-Locs. UC. 2701, UC. 2699, LSJU. 2609, UCLA. 3637, and TM. 1011 [=LSJU. 3300], all from the lower part of the upper half of the Chico formation in the type section of Chico Creek, Butte County (along with Submortoniceras chicoense (TRASK) and Baculites chicoensis (TRASK)) and LSJU. 3355, Pape Place, Mill Creek, Tehama County (along with Inoceramus naumanni YoKoYAMA).

A comparable specimen came from loc. CIT. 1053, upper part of the Holz shale in Santa Ana Mountains, Orange County. 
Thus, in California the species is found in the beds which are considered lower than those of C. newberryanum (MEEK). In the Nanaimo group of Vancouver Islands, according to UsHeR, C. multisulcatum (WHITEAVES), which is probably identical with C. yokoyamai (JIMBo), is said to occur in the Upper Qualicum formation, while C. newberryanum (MEEK) occurs in the Haslam and Ceder District formations.

In Japan and Sakhalin the ranges of C. yokoyamai (Jıмво) and C. kossmati MATSUмото overlap each other in the "Lower Hetonaian" (zone of Inoceramus schmidti), but the former species appears earlier than the latter. Some of the examples of C. yokoyamai (Јімво), including Jімво's original specimen, have not yet been stratigraphically well located.

\section{Canadoceras mysticum Matsumoto}

Pl. 15, figs. 2, 3a-c

1954. Canadoceras mysticum Matsumoto, Cret. System Japanese Islands, Appendix, p. 307, pl. 15 [31], figs. 2a, b; pl. 19 [35], figs. 1a, b, c, 2a, b; text-figs. 29 [75] and 30 [76].

Holotype.-GK. H 5184, from the zone of Inoceramus schmidti, Teshio Province, Hokkaido (MAтsumoto, 1954a, pl. 19 [35], fig. 1a, b, c).

Material.-The Californiar specimens which I refer to this species are UCLA. 28842 (Pl. 15, fig. 3a-c), from loc. UCLA. 3637, and UCLA. 28844 (PI. 15, fig. 2), from loc. UCLA. 3636 (both Coll. L. E. \& R. B. SAUL). There are some fragmentary whorls which are comparable with this species.

\section{Measurements.-}

\begin{tabular}{|c|c|c|c|c|}
\hline Specimen & Diameter & Height & Breadth $(\mathrm{B} / \mathrm{H})$ & Umbilicus ( $\%)$ \\
\hline GK. H 5184 & $\left\{\begin{array}{l}92.5 \\
82.0\end{array}\right.$ & $\begin{array}{l}40.8 \\
35.5\end{array}$ & $\begin{array}{l}31.2(0.76) \\
30.4(0.85)\end{array}$ & $\begin{array}{l}25.0(27) \\
22.3(27)\end{array}$ \\
\hline UCLA. 28842 & $\left\{\begin{array}{l}71.0 \\
-\end{array}\right.$ & $\begin{array}{l}30.3 \\
22.8\end{array}$ & $\begin{array}{l}26.9(0.88) \\
20.4(0.89)\end{array}$ & $\begin{array}{l}20.6(29) \\
-\end{array}$ \\
\hline UCLA. 28844 & 65.0 & 29.0 & c. $11 \times 2(0.76)$ & $16.4(25)$ \\
\hline
\end{tabular}

Specific diagnosis.-The whorl is considerably involute with a fairly narrow umbilicus. It is relatively compressed, with a narrowly arched venter and flattened flanks. The ribs are numerous, relatively weak, and nearly radiate or gently flexuous on the main part of the flank, passing gradually to a ventral projection. In more or less late growth-stage the constrictions and major ribs are prorsiradiate. The constrictions are frequent but shallow. The umbilical tubercles are indistinct, being discernible as weak bullae along the major ribs or sometimes almost obsolete. The suture is of typical Pachydiscus pattern.

Remarks.-The two illustrated specimens are not quite identical in the curvature of the ribs, obliqueness of the constriction and weakness of the tubercles. The differences are minor and can be ignored as variation within the same species, as in the case of the Japanese specimens. In the essential features the Californian examples match the Japanese ones. The ribs, which are numerous and rather crowded on the immature whorls, become more distant on the adult whorl, as shown in the holotype. Although the adult body chamber is only 
imperfectly preserved in one of the Californian specimens, the tendency towards this character is well recognized on the outer whorl.

The weakening of the ornament in this species foreshadows Patagiosites. The latter genus is represented in California by a species which occur in strata probably younger than the beds containing C. mysticum.

Occurrence.-Locs. UCLA. 3637 and UCLA. 3636 on Chico Creek, lower part of the upper half of the Chico formation in this area, Butte County, east side of the Sacramento Valley, California. From the same localities Canadoceras yokoyamai, Submortoniceras chicoense, and Baculites chicoensis, among others, have been obtained.

C. mysticum is a rare species in the Japanese Campanian. Its discovery, although rare, in California is noteworthy.

\section{Genus Patagiosites Spath, 1953}

Type-species.-Ammonites patagiosus SCHLÜTER, 1867.

Generic diagnosis.-See SPATH, 1953 (Falkland Isl. Dep. Survey, Sci. Rep., No. 3), p. 38; Wright in MOORE [Editor], 1957, p. L 380.

Remarks.-I once pointed out the close affinity of Patagiosites with Canadoceras (MATsumoto, 1954a, p. 294). Thus I agree with Wright (1957, p. L 380) in regarding Patagiosites as probably a reduced derivative of Canadoceras. SpATH's statement that the suture of Patagiosites should be puzosid type and less advanced than that of Anapachydiscus or Pachydiscus (s.s.) is not tenable. The suture is quite similar to that of Anapachydiscus, Pachydiscus, or Canadoceras.

In California there is one species of Patagiosites as described below. The occurrence of this genus in California is quite reasonable, because Canadoceras is common in the northern Pacific region. In fact Canadoceras compressum Matsumoto (1954a, p. 310, pl. 20 [36], figs. 1, 2a, b, 3; text-fig. 31 [77]) from Japan is better transferred to Patagiosites.

\section{Patagiosites arbucklensis (ANDERSON)}

Pl. 16, fig. 1a-c; Pl.17, figs. 1a, b, 2a, b

1958. Eupachydiscus arbucklensis ANDERSON, Geol. Soc. Amer., Memoir 71, p. 223, pl. 44, fig. 1, 1a; pl. 45, fig. 1 .

1958. Eupachydiscus willgreeni ANDERson, Geol. Soc. Amer., Memoir 71, p. 223, pl. 46 , fig. 2.

1958. Nowakites dobbinsi Anderson, Geol. Soc. Amer., Memoir 71, p. 231, pl. 44, fig. 2, 2a.

1958. Nowakites rumseyensis ANDERson, Geol. Soc. Amer., Memoir 71, p. 231, pl. 45 , fig. 3.

1958. Puzosia (Parapuzosia) arenaica ANDERson, Geol. Soc. Amer., Memoir 71, pl. 46 , fig. 4 , 4 a.

1958. Puzosia (Holcodiscoides) gorrilli ANDERSON, Geol. Soc. Amer., Memoir 71, p. 240, pl. 46, fig. 4, $4 \mathrm{a}$. 
Holotype.-The holotype by original designation is the specimen illustrated by ANDERson, 1958, pl. 44, fig. 1, 1a. Its locality is CAS. 25730.

Material.-In addition to the holotype and paratype of ANDERson's Eupachydiscus arbucklensis, there are many specimens from the same type locality (CAS. 25730) (Coll. H. L. DobBINs). They received from ANDERson (1958) five other new names, but represent specimens of different growth-stages or varieties of the same species (see above synonymy). There is another example from loc. CAS. 33717 (Coll. H. L. DoBBINS).

In the collections of other institutions, from the same locality and its vicinity, there are still more examples of this species. They are as follows:

UC. 14939, with a label of Eupachydiscus arbucklensis ANDERSON, from loc. UC. 190, Sand Creek, west of Arbuckle (Coll. no record)

LSJU. 8517-A (Pl. 16, fig. 1a-c), LSJU. 8518 (Pl. 17, fig. 1a, b), LSJU. 8521 (Pl. 17, fig. 2a, b), LSJU. 8517-B, 8519, 8522, 8523 from loc. LSJU. 3169 (Coll. J. M. KIRBY)

Specimens, without register numbers, from locs. SOC. K-237, K-238, K-239, and K-240 (all Coll. M. V. KIRK)

\section{Measurements.-} Specimen

CAS. holotype

CAS. paratype

UC. 14939

LSJU. 8516

"I $\quad(1 / 4$ vol. early $)$

LSJU. 8517

LSJU. 8518

LSJU. 8520

120.0

Diameter
119.7
170.5
118.5
106.4
85.7
c. 180
35.5
120.0

Height
48.0
68.0
47.5
44.7
37.2
72.0
14.7
50.0

$\begin{array}{lr}\text { Breadth (B/H) } & \text { Umbilicus (\%) } \\ 42.0(0.87) & 36.5(30) \\ 65.0(0.95) & 51.3(30) \\ - & 35.6(30) \\ - & 30.3(28) \\ - & 22.6(26) \\ 62.6(0.87) & 59.5(33) \\ 13.8(0.93) & 9.8(28) \\ 43.5(0.87) & 33.4(29)\end{array}$

Diagnosis.-The shell is discoidal, moderately involute, and fairly large, growing rather slowly, with an umbilicus of moderate size, so that it resembles Puzosia. The whorl is somewhat higher than broad; the proportion of its height and breadth is $10: 8-9.5$. It has a narrowly arched venter, rather flattened or only slightly convex flanks, with the maximum breadth near the umbilical margin, and a steeply inclined, but not vertical, umbilical wall.

The inner whorls, of diameters below $50 \mathrm{~mm}$. or so, are ornamented with numerous flexuous ribs, umbilical tubercles, and periodic constrictions. The ribs are of unequal length and strength; the periodic major ribs are provided with prominent tubercles at the umbilical shoulder and usually, but not always, bordered by constrictions; many of the minor ribs start near the umbilical margin, sometimes tending to be united with the major ones near the umbilical tubercles; a few minor ribs are shorter than others, appearing only near the mid-flank. On the venter all the ribs are bent forward and separated by the interspaces, which are as narrow as or slightly broader than the ribs.

On the middle whorl, at diameters from $50 \mathrm{~mm}$. to about $100 \mathrm{~mm}$., the ribs and the tubercles are weakened. The major ribs are frequent but rather irregular in distance and strength; some of them are very weak. The umbilical tubercles are bullate. Narrow and shallow constrictions are discernible along some of the 
major ribs. The ribs and constrictions show a fairly prominent ventral projection.

On the adult whorl, at diameters over $100 \mathrm{~mm}$., there are distant ribs, which are broadened and weakened towards the venter; minor ribs are scarcely discernible, except for occasional, feeble, interstitial ones. A few shallow and narrow depressions along the major ribs may be very weak constrictions.

The suture is similar to those of Canadoceras newberryanum (MEEK) and C. kossmati Matsumoto, but the elements are narrower and the "third and fourth lateral lobes" are less oblique than those of those species. In other words, the first external subdivision of $U_{5}[=S]$ is situated outside the umbilical shoulder on the main part of the flank.

Variation.-The ontogenetic change of characters is remarkable, as described above. The change takes place at varying diameters. In other words the Canadoceras type of multicostation of moderate intensity remains until later growth-stage in one specimen than in others, although weakening of the ornament is the general tendency of this species. It is presumably this situation that led ANDERSON (1958) to set up a number of unnecessary specific names under various generic names. The holotype of Nowakites dobbinsi ANDERson (1958, p. 231, pl. 44, fig. 2, 2a) is nothing but the inner, immature whorl of the present species. That of Nowakites rumseyensis ANDERSON (1958, p. 231, pl. 45, fig. 3) is a relatively strongly ribbed, immature example of the present species. That of Eupachydiscus willgreeni ANDERSON (1958, p. 223, pl. 46, fig. 2) is poorly preserved, but is probably a variant of the present species, with relatively persistent multicostation. That of Puzosia (Holcodiscoides) gorrilli ANDERSON (1958, p. 240, pl. 46, fig. 3) is again a variant of the present species in which Canadoceras like character persists for relatively long period. That of Puzosia (Parapuzosia) arenaica ANDERSON (1958, p. 238, pl. 46, fig. 4, 4a) is a poorly preserved specimen, but is comparable with the inner whorl of the present species. All of these holotypes of ANDERSON came from one and the same locality, CAS. 25730, where the holotype and paratypes of the present species were also obtained. Numerous specimens from another locality, LSJU. 3167, which is close to CAS. 25730, indicate similar variation. Some of them (e.g. LSJU. 8521) show much weakened ornament even on the septate whorl.

Remarks.-This species is a peculiar form, superficially similar to Mesopuzosia in its inner whorls and to Pachydesmoceras in its outer whorl. It has, however, sutures of Pachydiscus type and umbilical tubercles, unlike the members of Puzosinae. Its inner whorl closely resembles that of Canadoceras newberryanum (MEEK) (1876, pl. 4, fig. 3, 3a, 3b) (see also p. 53 of this paper). It is, as a whole, close to Canadoceras mysticum Matsumoto (1954a, p. 307, pl. 15 [31], fig. 2a, b; pl. 17 [35], figs. 1a-c, 2a, b; text-figs. 29 [75], 30 [76]; see also p. 59 of this paper) which has weaker tubercles than other species of Canadoceras. Its ribs are, however, still weaker and its constrictions are less distinctly marked than in C. mysticum. Although there is variation, the weakening of the ornament is generally so diagnostic that the present species is better referred to Patagiosites than to Canadoceras. 
I suggested previously (Matsumoto, 1954a, p. 296) that Patagiosites Spath, 1953 might be included in Canadoceras SPATH, 1922. It is still possible to regard Patagiosites as a subgenus of Canadoceras, but the weakening of the ornaments is so remarkable that the generic separation is in my view justified.

Although SPATH considered Patagiosites as a descendant of Anapachydiscus YABE and SHIMizU, 1926, the former is undoubtedly derived from Canadoceras, while the smooth derivative of the latter is Neodesmoceras Matsumoto, 1947 (see SAITo and Matsumoto, 1954).

The syntypes of the type species of Patagiosites, Ammonites patagiosus SCHLÜTER (1867, p. 22, pl. 4, figs. 4a, b, 5), plaster casts of which have been sent to me from the Geological and Palaeontological Institute, University of Bonn, have almost obsolete ribs even on whorls of relatively small size. The Californian species keeps more distinct ribs than $P$. patagiosus from Europe. In this respect it is intermediate between Canadoceras and Patagiosites.

Another atypical feature concerns the constrictions. As compared with Patagiosites patagiosus (SCHLÜteR) and P. compressus (MATSUmoto) [= Canadoceras compressum MAтsumoto, 1954a, p. 310, pl. 20 [36], figs. 1, 2a, b, 3], the present species has not so well marked constriction. This is similar to the peculiar feature of Canadoceras n. sp. (?) aff. C. hoepeni Collignon from loc. LSJU. 3355 (see p. 53). Both the ribs and constrictions are weakened in $P$. arbucklensis. But since it does have constrictions, it is better referred to Patagiosites than to any other genera.

In the weak ornament and moderately wide umbilicus, the present species is apparently similar to such forms as 'Pachydiscus' simplex VAN HoEPEN (1921, p. 25, pl. 5, figs. 3, 4; text-fig. 5) and 'Parapachydiscus' umtafunensis SpatH (1922, p. 133, pl. 9, fig. 4a, b) from the Senonian of Pondoland. On examining SPATH's original specimens (BM. C. 19434, 19435), I noticed that they have no direct connection with Patagiosites. They are, in my opinion, closely related to Pseudopuzosia Spath (emend. Matsumoto, 1954), which is weakly ornamented throughout life and has no well marked constrictions. Contrary to Collignon's view, Hoepenites Collignon, 1952 does not include these two species, since it is a synonym of Neopachydiscus, YABE and SHIMIzU, 1926, to which they are not referable.

Occurrence.-Localities CAS. 25730, LSJU. 3169, UC. 190, SOC. K-237, SOC. K-238, SOC. K-239, SOC. K-240, and CAS. 33717, in Sand Creek and its vicinity; probably basal part of Forbes formation, Rumsey Hills, west side of the Sacramento Valley.

The species occurs fairly commonly in the above portion, associated with Inoceramus schmidti MICHAEL and other Campanian species. For some reason, the species has not yet been found outside the limited area of Rumsey Hills.

\section{Family Kossmaticeratidae SPATH, 1922}

Various members of the Kossmaticeratidae occur in the Cretaceous of Japan, Sakhalin, and Alaska (see Matsumoto, 1955b, 1956, 1959a). Naturally they 
occur also in the Cretaceous of California, although the hitherto described species are not numerous. For instance Hulenites Matsumoto, 1955, which is the earliest genus of the family, is represented by the Albian species from California, H. reesidei (ANDERSON, 1938) [type-species], H. jimboi (ANDERSON) (1938), and allies. ANDERSON (1958, p. 236, pl. 12, figs. 3, 3a, 4) recently altered the name of the second species to Puzosia (Parapuzosia) waringi, because he considered that Puzosia jimboi had been preoccupied. So far as I know, Puzosia jimboi did not appear as a valid name in the literature up to ANDERson's date (1938). Therefore Hulenites jimboi should be valid, unless it can be proved to be identical with $H$. reesidei (ANDERSON).

Marshallites cumshewaensis (WHITEAVES) (1884, p. 208, pl. 24, fig. 1) originally came from the Queen Charlotte Island, British Columbia. It has recently been found fairly abundantly from the probably Upper Albian and Cenomanian of southeastern Alaska (MAтsumoтo, 1959a, p. 63, pl. 17, figs. 1-4; pl. 19, fig. 2; pl. 20, fig. 2), but has not yet been confirmed to occur in California.

Kossmaticeras (Madrasites) voyanum ANDERSON (1958, p. 241, pl. 37, fig. $5,5 a, 5 b)$ is based on a single specimen, UC. 12115, from Cottonwood Creek, Shasta County, California, which was once described as Holcodiscus cf. theobaldianus by ANDERSON (1902, p. 101, pl. 5, figs. 126, 127; pl. 10, fig. 197). On examining the holotype I am now convinced that it is an example of Marshallites MATSUmoto, 1955 and that it is very closely allied to $M$. olcostephanoides MATsUмото (1955a, p. 129, pl. 8, figs. 5a, b, 6, 7a, b; text-fig. 4). I have already mentioned it in comparison with the species from Japan, Sakhalin, and Alaska (MATsUмото, 1955a, p. 131; 1959a, p. 65).

There is another example of Marshallites in the collection of M. V. KIRK, from loc. SOC. K-205, Roaring River, Shasta County, where Sciponoceras cf. baculoide (MANTELL) is associated. It is identical with a probably new (but not yet described) species from the Upper Cenomanian of Hokkaido, which is characterized by the strong involution of the whorl and the numerous, fine ribs.

Eogunnarites WRIGHT and MATSUMOTO, 1954 seems to be rare in California, but a specimen from loc. CAS. 2233, North Fork of Cottonwood Creek, Shasta County (Coll. F. M. ANDERson) is referable to a probably new (but again not yet described) species of Eogunnarites from the Upper Cenomanian of Hokkaido.

No representatives of Eomadrasites MATSUmoto, 1955, Mikasaites MATSUмото, 1956, and Maccarthyites MATSUMото, 1959 have yet been discovered in California. They are specialized members in the Cenomanian and rare even in the type areas of Japan and Alaska.

Few examples of Kossmaticeras DE Grossouvre, 1901 (see Collignon, 1955, p. 12; Matsumoto, 1955a, p. 140) from California have been at my disposal. A specimen from loc. UC. A-173, RICHARDson's ranch, 4 miles north of Montague, Siskiyou County is probably identical with a Japanese Lower Senonian form, Kossmaticeras aff. japonicum Matsumoto (see Matsumoto, 1956, p. 180, pl. 14, fig. 2a, b; pl. 15, fig. 1a, b). The holotype and a paratype of Nowakites klamathonis ANDERSON (1958, p. 230, pl. 35, fig. 1, 1a, 1b) from a locality in the same 
RICHARDSON's ranch, Siskiyou County resemble Kossmaticeras aff. japonicum MATSUMото (see above) in the fine ribbing on the inner whorl, slight intersection of the constriction with the ribs, and other features, but their body whorl is nearly as inflated as Kossmaticeras pachystoma (Kossmat) (1897, p. 39 [146], pl. 7 [18], fig. 1a-d; Matsumoto, 1956, p. 177, pl. 14, figs. 3, 4a, b; text-fig. 1). Unlike Nowakites their umbilical tubercles are very weak.

Yokoyamaoceras WRIGHT and MATSUMoto, 1954 is not rare in Japan and Sakhalin, ranging from the Upper Turonian to the Santonian, but its existence in California has not yet been confirmed. Other variously specialized members of the Upper Senonian Kossmaticeratidae, which distribute primarily in the southern Hemisphere (including southern India), have not yet been discovered on the West Coast of North America. A single, but interesting, example at my disposal is Pseudokossmaticeras cf. tchihatcheffi (Вӧнм, 1927). It is represented by a specimen collected by H. HANNIBAL and A. W. AMBROSE and preserved at the Stanford University. The locality, now received No. LSJU. 3347, is recorded only as "Black Mountain, a float boulder 1/8 mile of HoFFMASTER's Mountain House, California". Among the associated species there is Baculites rex ANDERSON (see Part I of this paper, p. 136, pl. 39, fig. 2a-c). There are several Black Mountains in California. Some are in the area of the Franciscan series, but the rock matrix of the fossils under consideration has no sign of tectonic or metamorphic effect. Therefore Black Mountain in Joaquin Rock Quadrangle, Fresno County and that in the Hornbrook area, Siskiyou County are possible localities. Pseudokossmaticeras is known in southern India, Turkey, Europe, and Madagascar. Its discovery in California is worthy to note, but the material is not sufficient for full description in this paper.

To sum up we have to wait for further acquisitions for the monographic descriptions of the Kossmaticeratidae from California.

\section{Family Acanthoceratidae DE GrossouvRe, 1894}

In the available material from California and adjacent areas I have identified species of Graysonites, Mantelliceras, Calycoceras, Acanthoceras, Romaniceras, Eucalycoceras (?), and Kanabiceras. I describe below most of them, since they are taxonomically interesting and stratigraphically important, although each of them is not always represented by a large number of specimens.

\section{Genus Graysonites Young, 1958}

Type-species.-Graysonites lozoi Young, 1958.

Generic diagnosis.-Inner whorls are similar to those of compressed Mantelliceras; the adult whorl resembles that of Sharpeiceras, having equally long, and distant ribs, but the two ventrolateral tubercles are united into a ventrolateral horn.

Remarks.-Graysonites seems to have been already noticed by ADKINs (1933, p. 363; also personal information given by J. P. CoNLIN and C. W. WRIGHT), 
but was at first published by Young (1958) as a valid genus. It is evidently closely related to Mantelliceras and Sharpeiceras. It occurs in the Lower Cenomanian of Texas. There are some Japanese examples, as briefly mentioned previously (MATsumoto, SAito, and Fukada, 1957, p. 3; Matsumoto, 1959a, p. 82), but they have not yet been monographed. The species which I have identified in California is described here.

\section{Graysonites wooldridgei YounG \\ Pl. 18, fig. 1a-c; Text-figs. 24-27}

1958. Graysonites wooldridgei Young, Jour. Paleont. vol. 32, no.1, p.175, pl. 2, figs. 1-4; pl. 3, figs. 2, 4; text-fig. 3c, d, f.

Holotype.-UT. 19819, from the Grayson marl of Denton County, Texas, Lower Cenomanian (YounG, 1958, p. 175, pl. 2, figs. 1-4; text-fig. 3c, d).

Material.-The Californian specimens which I identify with this species are a large specimen, UC. 32425, illustrated here (Pl. 18, fig. 1a-c; Text-figs. 24, 26), from loc. SOC. K-193A, and several other fragmentary specimens (Text-figs. 25, 27 for one of which) from the same loc. SOC. K-193A and also locs. SOC. K-192F, $\mathrm{K}-191$ and $\mathrm{K}-190 \mathrm{~F}$, all collected by M. V. KIRK.

Measurements.-(on somewhat deformed specimens)

\begin{tabular}{|c|c|c|c|c|}
\hline Specimen & Diameter & Height & Breadth $(\mathrm{B} / \mathrm{H})$ & Umbilicus (\%) \\
\hline UC. $32425\left\{\begin{array}{l}(\text { last whorl }) \\
(1 / 2 \text { vol. early })\end{array}\right.$ & $\begin{array}{l}284.0 \\
182.5\end{array}$ & c. $\begin{array}{r}123 \\
85\end{array}$ & $\begin{array}{l}(0.65) \\
(0.57)\end{array}$ & $\begin{array}{l}76.0(27) \\
41.0(22.5)\end{array}$ \\
\hline $\begin{array}{l}\text { Another fragmentary } \\
\text { one (Figs. 25, 27) }\end{array}$ & - & 75.0 & $49.0(0.65)$ & - \\
\hline $\begin{array}{l}\text { Holotype (after Young, } \\
\text { 1958) }\end{array}$ & 125.0 & 45.0 & $26.5(0.59)$ & $26.5(21)$ \\
\hline UT. 19808 ( & 110.0 & 43.5 & $28.0(0.64)$ & $27.5(25)$ \\
\hline
\end{tabular}

Description.-The full-grown shell is fairly large. Slightly more than a half of the inner whorl is overlapped by the outer. The umbilicus is fairly narrow. The whorl is much higher than broad, the proportion between height and breadth is about the same as the Texas examples, ranging from 10:7 to 10:5.7. The flanks are convergent; the siphonal side is relatively narrow and flattened.

On the immature whorl the ribs are prorsiradiate, relatively weak, alternately long and short, and fairly dense; even the short ribs start from near the umbilical shoulder; the tubercles are weak, bullate at the umbilical ends of the long ribs, very faint near the mid-flank, and doubled at the ventrolateral shoulder; the clavate, upper ventrolateral ones forming the edge of the flat venter, while the blunt lower ventrolateral ones being situated on the slope of the flank, close to the ventrolateral edge.

On the adult whorl the ribs are slightly prorsiradiate, distant, separated by wider interspace than the ribs themselves, becoming strong, and almost equally long; the umbilical tubercles are obsolete, the tubercles below the mid-flank are elevated on the strong ribs, and the large, almost horn-like, ventrolateral tubercles, which are developed by uniting the double tubercles of the preceding stage, are 


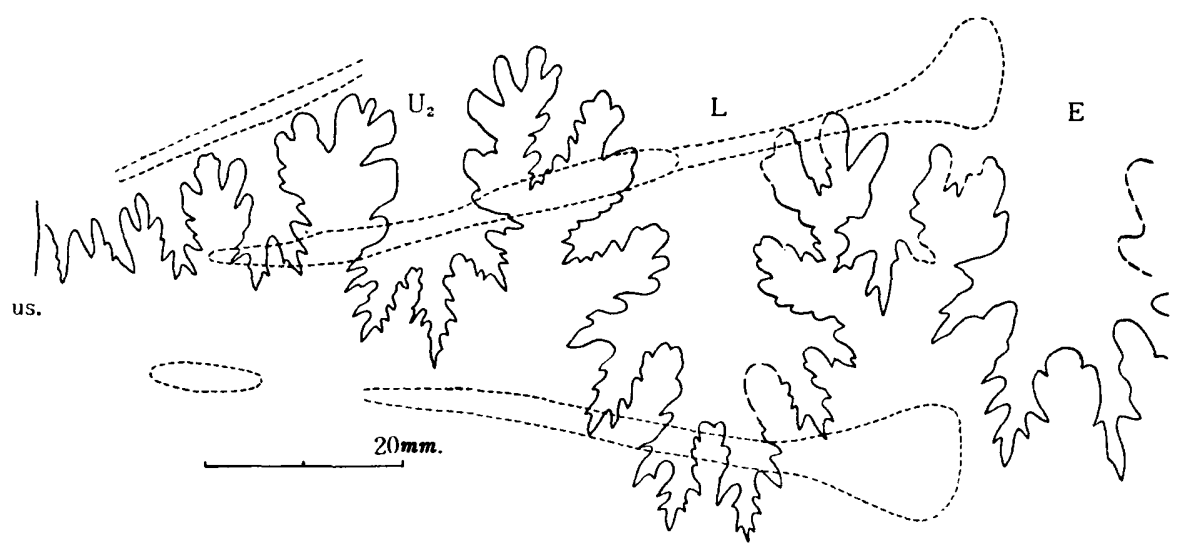

Fig. 24. Graysonites wooldridgei Young. External suture, at whorl-height= $85 \mathrm{~mm}$., breadth $=49 \mathrm{~mm}$. (see Fig. 26b), of a large example, UC. 32425 , from loc. SOC. K-193A, Roaring River, Ono Quadrangle, Shasta County. Dotted lines indicate the position of the ribs and the tubercles.

characteristic of the adult body whorl. The ribs cross the venter with decreased intensity, and the interval between the paired horned tubercles is concave.

The suture on the outer whorl is fairly deeply incised; the first lateral lobe (L) is the deepest, fairly narrow at its stem, and bipartite at its terminal; the second lateral lobe $\left(\mathrm{U}_{2}\right)$ is again narrow, much smaller than $\mathrm{L}$, and extremely asymmetric; $\mathrm{U}_{2}$ and several other auxiliary elements are descending; the saddles on both sides of $L$ are relatively large, asymmetrically bipartite; the one between $\mathrm{L}$ and $\mathrm{E}$ is the broadest and deeply divided.

Remarks.-In every character of both septate and body whorls the Californian specimens match so well the types of Texas that specific identity is certain.

The holotype, which I saw at the University of Texas, has the posterior portion of the adult body whorl. One of the Californian examples, which is

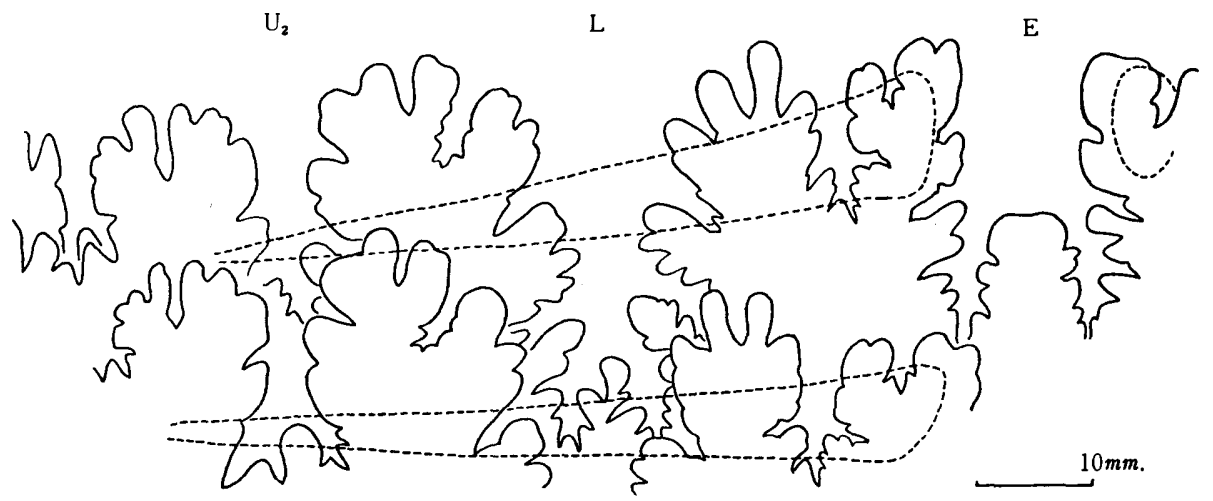

Fig. 25. Graysonites wooldridgei YounG. External suture, at whorl-height= $75 \mathrm{~mm}$, , breadth $=49 \mathrm{~mm}$. (see Fig. 27), of another example, from loc. SOC. K-193A, Roaring River, Ono Quadrangle, Shasta County. Dotted lines: approximate position of the ribs and the nodes. 


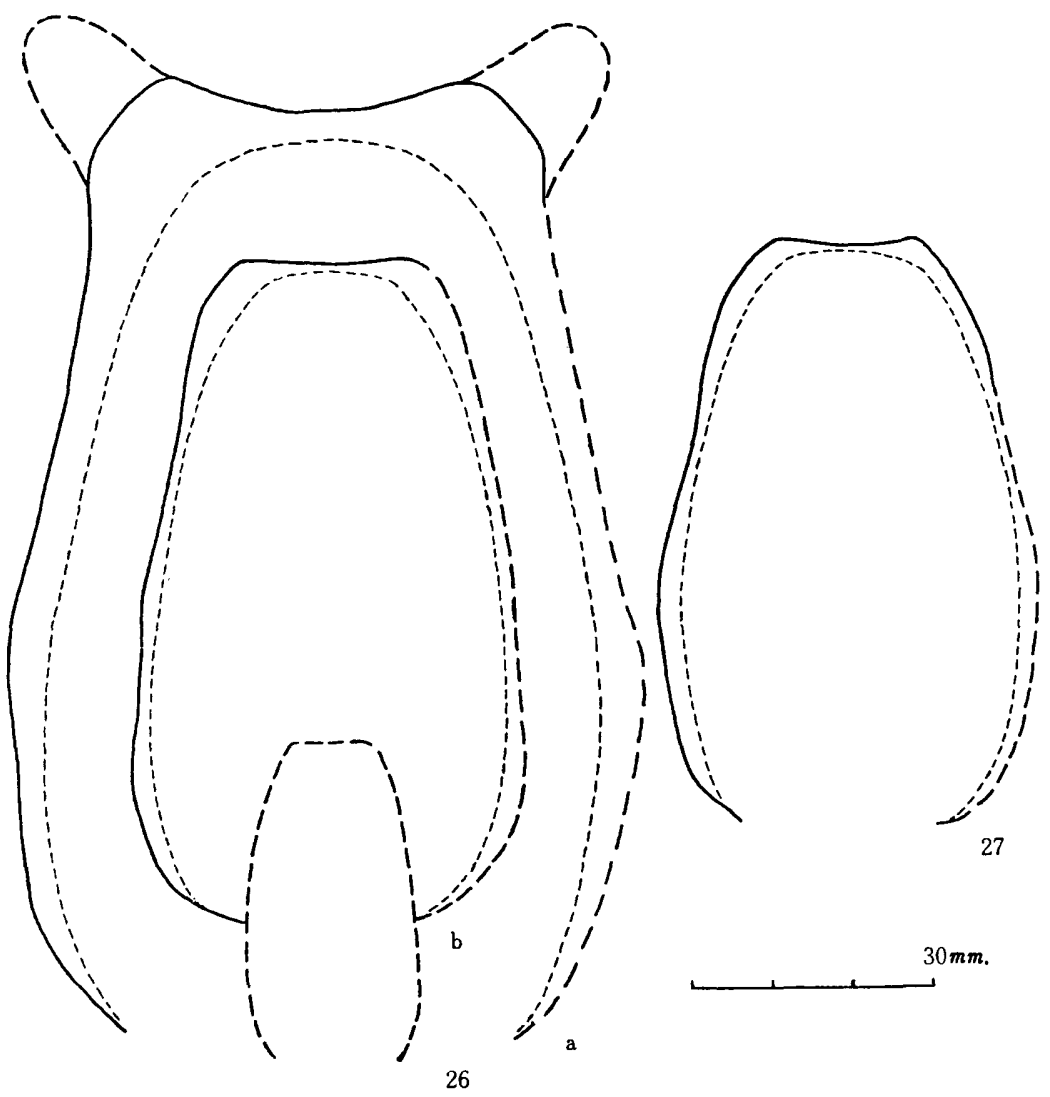

Figs. 26, 27. Graysonites wooldridgei Young. Whorl-sections at different growthstages, of a large specimen, UC. 32425 (Fig. 26a, b), and another (Fig. 27), from loc. SOC. K-193A, Roaring River, Ono Quadrangle, Shasta County. The horns drawn by broken lines are presumed from their bases.

larger than the holotype, preserves the body whorl of nearly a half volution, which shows the ornament of Graysonites type-the distant strong ribs of equal length, lateral tubercles, and horn-like ventrolateral tubercles.

The suture which is illustrated by Young (1958, text-fig. 3f) is not of the holotype but of an immature specimen of $85 \mathrm{~mm}$. in diameter. The apparent difference between that and these which I illustrate here is probably due to the difference of growth-stages and also method of illustration. I find no essential difference among them, except for minor variation, which Californian examples themselves do show.

Another, probably minor, difference between the Texas and Californian specimens is that YouNG (1958, p. 175; text-fig. 3c, outer diagram) observed that the ventrolateral horn develops from the lower ventrolateral tubercle on which the upper ventrolateral one is superimposed, while from the Californian specimens it is rather hard to judge which of the two ventrolateral tubercles submerges the other. On the actual specimens (of the holotype from Texas and the Californian 
examples) there is no significant distinction in this respect, and the disposition of the ventrolateral tubercles which Young showed on the middle and inner diagrams of his text-fig. 3c conforms well with my observation. YouNG showed in his diagrams as if the ribs completely disappeared on the siphonal side, but the actual specimens (and also photographs) show, as Californian ones do, much weakened ribs connecting the paired ventrolateral tubercles.

Although the above differences may be very slight and can be ignored as minor variation, I should consider a possibility of subspecific distinction between the two provinces. Until more specimens are obtained from both sides, the establishment of the subspecies should be suspended.

As regards the systematic position of $G$. wooldridgei YouNG, the original author (YounG, 1958, p. 172) suggested the possible relation with Mantelliceras, but placed it into Graysonites principally because of the "unusual suture pattern, the first lateral lobe of which is reminiscent of that of Neopulchellia". In my observation G. wooldridgei YouNG (including both Texas and Californian forms) is closer to a certain species of Sharpeiceras than any others in every character.

E. C. Allison has kindly showed me a set of interesting specimens, from loc. UC. B-2881, in the Upper Cretaceous terrain bordering Bahia Tourtugas [Cabo Tortolo], Baja California, Mexico (Coll. R. P. Miller and L. L. TABor, Richmond Petroleum Co., May, 1950). They are more or less secondarily deformed, but show diagnostic features in ornament, suture, etc. The size of the shell, if perfectly preserved, would be as large as that of the Californian specimen here described. The whorls are high and grow fairly rapidly, although the deformed condition does not enable us to do accurate measurements. On the septate whorl, below $80 \mathrm{~mm}$. in height, the ribs are weak, alternately long and short, rather crowded; the two ventrolateral tubercles are approximated, the tubercles slightly below the mid-flank are fairly distinct, and the umbilical tubercles are bullate, from which sometimes the secondary ribs branch out. On the larger whorl, which is probably adult but still septate, the ribs are strong and distant, the umbilical tubercles are obsolete, the mediolateral ones remain as elevations on the ribs, and large ventrolateral tubercles are developed by fusing from the two ventrolateral tubercles of the preceding stage. The suture is quite similar to those of G. wooldridgei YouNG and also Sharpeiceras indicum (Kossmat) (1897, p. 199 [103], pl. 24 [10], figs. 5a, b, 6a, b).

In almost all the above-mentioned characters the form represented by the specimens from Baja California is allied to G. wooldridgei YounG, but, at the same time, it closely resembles the original specimen (UC. S8234/35750) of "Sharpeiceras laticlavium (SHARPE) var. mexicanum (BösE)" (1927, p. 253, pl. 10, fig. 6 ; pl. 11, fig. 1) from the Buda limestone in Coahuila, northern Mexico, and also, as C. W. Wright (personal communication to E. C. Allison, April 1, 1957) correctly pointed out, it is similar in some respects to Sharpeiceras indicum (KossmaT) (op. cit.) from the "Middle" Ootatoor group of India.

The last species is, however, closer to Sharpeiceras laticlavium (SHARPE) (1855, p. 31, pl. 14, fig. 1a, b), the type-species of Sharpeiceras, than the others 
in that their ribs are rectiradiate with less frequent secondaries, and has almost equally strong and nearly, if not exactly, equidistant tubercles, and that the two pairs of ventrolateral tubercles persist, without showing any sign of approaching each other or uniting into one pair of horn-like tubercles. Anyhow the Baja Californian form is interesting, because it is one of the evidences for the intimate relationship between Graysonites and Sharpeiceras. The sutures of species of Graysonites are not so peculiar as Young considered, but are essentially similar to those of Sharpeiceras.
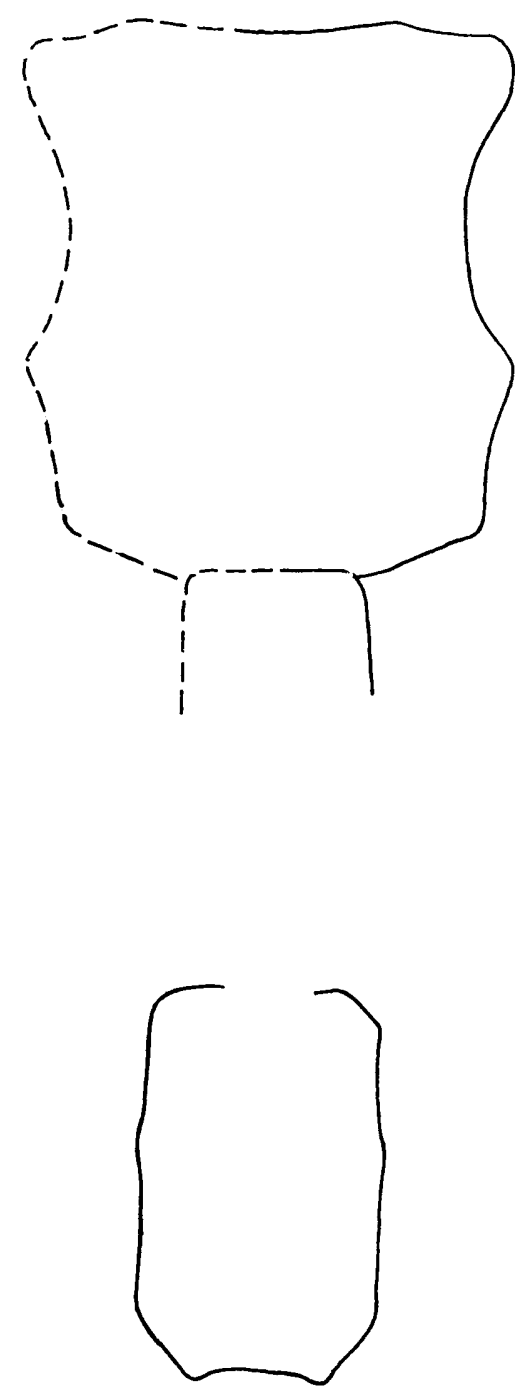

$30 \mathrm{~mm}$.

Fig. 28. Sharpeiceras cf. florencae Spath. An example from Buda limestone, Texas, UT. 15508 (Coll. Whitney, 1936). 
Sharpeiceras florencae SpATH (1925, p. 198, pl. 37, figs. a-d.) from the Upper Cretaceous of Maputoland, East Africa and from Persia (Douvillé, 1904, p. 239, pl. 31, fig. 3) has, on its large body whorl, distant, coarse ribs and strong tubercles, of which ventrolateral ones form projected horns. Although the two pairs of ventrolateral tubercles are still kept in this species, the resemblance of this species to a certain species of Graysonites cannot be denied. I saw two specimens of Texas which are probably referable to, or at least close to, Sharpeiceras florencae SPATH. The best example is UT. 15508 (Text-fig. 28), from "Onion Creek, I. \& G. N. Railway bridge, south of Manchaca, Travis County, Texas, upper beds of Buda limestone", on the body whorl of which the upper ventrolateral tubercle is superimposed on the horn-like lower ventrolateral tubercle. The other is UT. 15507, "Buda limestone, Blanco River, 1 mile above Railway bridge, San Marcos, Texas". In them the umbilical tubercles are distinct even on the outer whorl, as in S. florencae SpATH and other species of Sharpeiceras.

Contrary to our expectation all the species of Graysonites in Texas occur in the beds which are evidently lower than the Buda limestone. That limestone contains, in addition to the above-mentioned species of Sharpeiceras, Mantelliceras cantianum Spath [=M. budaense AdKINs, 1931, p. 41, pl. 2, fig. 3; pl. 4, fig. 10, BEG. 17017] (top of Buda limestone), and Budaiceras spp.

Judging from this stratigraphic evidence, the origin of Graysonites may not be in Sharpeiceras but in a certain other older genus. As suggested by Young (1958, p. 172 and other pages), what was called under the name of Submantelliceras SPATH, 1923 should be brought into comparison. In the available specimens of California, there is little evidence for this problem except several small specimens in the collection of M. A. MURPHY, who will eventually describe them.

Occurrence.-Localities SOC. K-193A, SOC. K-192F, SOC. K-191 and SOC. $\mathrm{K}-190 \mathrm{~F}$, all located close to one another along a southern branch of Roaring River in SE. $1 / 4$ of NE. $1 / 4$ of sec. 3 and NW. $1 / 4$ of sec. 2 , T. 29 N., R. 7 W., Ono Quadrangle, Shasta County, northwest side of the Sacramento Valley. According to M. V. KIRK, who collected the specimens, the localities are in a shale unit stratigraphically slightly below the more conglomeratic unit in the section of the Roaring River. This conglomeratic unit was regarded by ANDERSON (1938, 1958) as the base of the Upper Cretaceous. The localities are just outside, or near the edge of MURPHY's (1956, text-fig. 4) map of Lower Cretaceous. For a precise determination of their stratigraphic positions, more study is needed. Anyhow, the discovery of Graysonites wooldridgei from California throws a light for age correlation, because G. wooldridgei occurs, according to Young (1958, p. 171, 176) at a definite horizon in the Lower Cenomanian of the Gulf Coast.

\section{Genus Mantelliceras HYATT, 1903}

Type-species.-Ammonites mantelli J. SOWERBY, 1814.

Generic diagnosis.-See Matsumoto, SaIto, and Fukada, 1957 (Mem. Fac. Sci., Kyushu Univ., ser. D, vol. 6), p. 5 . 
Remarks.-Examples of Mantelliceras in California are at present very poor. The first published record of Mantelliceras in California is from the Franciscan group in Marin County by HERTLEIN (1956, p. 1987, figs. 1-4). Although the specimen is crushed, I agree with him in calling it Mantelliceras sp. Another probable example of Mantelliceras is the holotype of Acanthoceras lecontei ANDERSON (1958, p. 242, pl. 13, fig. 1, 1a) from loc. UC. A-3823 in Contra Costa County, not far from San Francisco. This is only a fragmentary whorl and hardly regarded as a well defined species.

Better and unmistakable representatives of Mantelliceras were discovered in Oregon by Dr. D. L. JoNEs, who kindly showed me his collections. I leave them undescribed, as they will be monographed by Dr. JoNEs.

The four species which ANDERson (1958) described under Mantelliceras are not referable to that genus, but should be Calycoceras, Eucalycoceras (?), and Romaniceras, as are discussed in the respective headings.

\section{Genus Calycoceras HYATT, 1900}

Type-species.-Ammonites navicularis MANTELL, 1822.

Generic diagnosis.-See MATsumoto, SAIto, and FukAdA, 1957, p. 8-9, where relationships with other genera are also discussed.

\section{Calycoceras cf. spinosum (KossmaT)}

Pl. 21, fig. 2; Text-fig. 29

Compare.-

1865. Ammonites rhotomagensis, StoLiczka, pro parte, Mem. Geol. Surv. India, Pal. Indica, ser. 3, vol. 1, p. 68, pl. 35, fig. 2.

1898. Acanthoceras newboldi var. spinosa Kossmat, Beitr. Pal. Geol. Oesterr.Ung. Or., vol.11, p. 1 [114], pl. 2 [13], figs. 2a-c, 3a, b; pl. 3 [14], fig. $1 \mathrm{a}, \mathrm{b}$.

1937. Calycoceras (Eucalycoceras) newboldi var. spinosa, Collignon, Ann. Géol. Serv. Mines, Madagascar, vol. 8, p. 39.

1951. Calycoceras newboldi var. spinosa, WRIGHT and WRIGHT, Palaeontogr. Soc., 1950, p. 26.

1958. Calycoceras spinosum, Matsumoto, SAIto, and FUKada, Mem. Fac. Sci., Kyushu Univ., ser. D, vol.6, p.13, pl.3, fig.1a-c; pl. 4, figs. 1a-c, 2a, b; text-fig. 3.

Types.-Acanthoceras newboldi var. spinosa was established by Kossmat (1898) on several syntypes. MAtsumoto, SAIto, and FukadA (1958) have ranked it as a species. They described its Japanese representatives in comparison with Kossmat's syntypes and other author's hypotypes. One of the specimens illustrated by Kossmat (1898, pl. 2 [13], fig. 2a-c) is here designated as the lectotype.

Material.-Three Californian specimens of imperfect preservation are at my disposal: the one (Pl. 21, fig. 2; Text-fig. 29), from loc. CAS. 33725 (Coll. no record), and two others, LSJU. 8604, from loc. LSJU. 3281 (Coll. S. W. MULLeR et al.). 


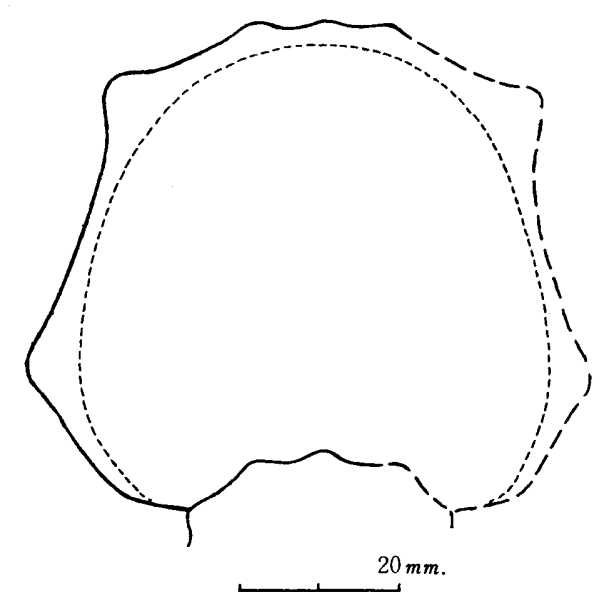

Fig. 29. Calycoceras cf. spinosum (Kossmat). Whorl-section, partly restored, of a fragmentary specimen, from loc. CAS. 33725, Willows Creek, Fruto Quadrangle, Glenn County. See Pl. 21, fig. 2 for the side view.

\section{Measurements.- \\ Specimen}

One from CAS. 33725

LSJU. 8604a

Descriptive remarks.-The specific diagnosis was given on the occasion of describing the Japanese examples (MAтsumoto et al, 1957, p. 14). Although the Californian specimens are imperfectly preserved, they are best compared with C. spinosum (Kossmat) as redefined, in their polygonal costal sections, strong and moderately distant ribs on the outer whorls, spinose, umbilical and ventrolateral tubercles, pattern of sutures, etc.

MATSUmото et al (1957) have already mentioned the distribution and affinities of C. spinosum. As this species is widespread, its discovery on the Pacific side of America is not unexpected.

Occurrence.-Loc. CAS. 33725, a shaly unit in Willows Creek, somewhat above the "basal conglomerate" Fruto Quadrangle; loc. LSJU. 3281, a shaly unit ("Antelope shale") apparently below the Venado sandstone, north of Sites, Lodoga Quadrangle, both on west side of the Sacramento Valley.

\section{Calycoceras ef. orientale MAtsumoto, SAIto, and Fukada}

Pl. 19, fig. 1a, b; Text-fig. 30

\section{Compare.-}

1957. Calycoceras orientale Matsumoto, SaIto \& Fukada, Mem. Fac. Sci., Kyushu Univ., ser. D, vol. 6, p.16, pl. 5, fig. 1a, b, c; pl. 7, fig. 1.

? 1958. Calycoceras (Eucalycoceras) diabloense ANDERSon, Geol. Soc. Amer., Memoir 71, p. 243, pl. 23, figs. 4, 5.

Holotype.-GT. I-3168, from loc. T711b, upper part of bed IIb, in the Middle Yezo group, the Abeshinai-Saku area, Teshio Province, Hokkaido, Japan. 
Material.-The Californian example which I describe under the above heading is a fairly large specimen, UC. 35737, from loc. UC. A-4864 (Coll. I. Valov, 1948), which is associated with another small fragment. It is fairly well preserved on one side, but unfortunately much eroded on the other. The holotype of "Calycoceras (Eucalycoceras) diabloense ANDERSON" (1958, p. 243, pl. 22, figs. 4, 5), from loc. CAS. 28104 [ $=25627]$ is probably another example of this species.

\section{Measurements. Specimen} Diameter

Height

$$
\text { Breadth (B/H) Umbilicus ( } \% \text { ) }
$$

GT. I-3168 (MATSUMOTO et al.)

Descriptive remarks.-The Californian specimens show rapid growth of whorls, relatively high whorls, flattened, instead of inflated flanks, an arched venter along the intercostal section, a polygonal costal section, prominent ribs which are alternately long and short, prominent ventrolateral and umbilical tubercles on the long ribs, but less prominent lower ventrolateral tubercles on some of the short ribs. The suture is the same type as C. newboldi (Kossmat) (1897, p. 4 [111], pl. 1 [12], figs. 2a, b, 3a-c; pl. 3 [14], fig. 2), with fairly deep lobes and minor subdivisions.

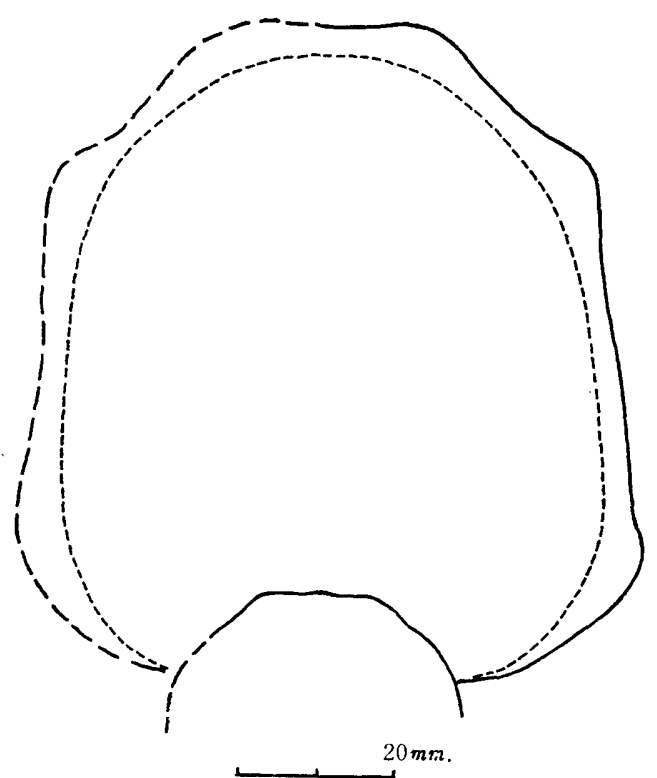

Fig. 30. Calycoceras ef. orientale Matsumoto, Saito \& Fukada. Cross section of the body whorl, partly restored, of a specimen, UC. 35737, from loc. UC. A-4864, Clark Valley (Willows Creek), Fruto Quadrangle, Glenn County. See Pl. 19, 1a, b for other views. 
All of the above characters are diagnostic features of Calycoceras orientale Matsumoto, Saito, and Fukada (1957, p. 16, pl. 5, fig. 1a, b, c; pl. 7, fig. 7) recently established on the basis of the Japanese materials.

One feature which was overlooked by MAтsumoto et al, but actually exists in the Japanese type specimens, and is distinctly observed in the Californian examples, is that the ribs are more or less prorsiradiate and sometimes slightly flexuous on the flanks. This is especially well exemplified on the inner whorls, while some of the ribs on the adult body whorl are relatively rigid.

One of the Californian specimens has a slightly larger umbilicus than the Japanese holotype, about one third of its inner whorl being overlapped by the outer. This is a minor difference which can be well regarded as a variation.

The manuscript of ANDERSoN's (1958) recent paper must have been written before our paper of the Japanese Acanthoceratids (MATsumoto, SAITo, and FuKADA, 1957) was published. He had good reasons to establish a new species, Calycoceras (Eucalycoceras) diabloense ANDFRson (1958, p. 243, pl. 23, figs. 4, 5). His holotype almost certainly belongs to $C$. nrientale Matsumoto, SaIto, and FUKADA, and thus diabloense is probably a synonym of orientale.

Occurrence.-Loc. UC. A-4864, Clark Valley, (Willows Creek), Fruto Quadrangle, Glenn County, west side of the Sacramento Valley. The stratigraphic position of this locality is, in my observation, in the middle of the shale formation, which is apparently below the Venado sandstone equivalent. $\mathrm{S}$. CHUBER and I found many specimens of Inoceramus labiatus ScHLoTHEIM, a Lower Turonian index, at the top of this shale unit, about 1200 feet (366 meters) stratigraphically higher than this locality. Locality CAS. 33725, where Calycoceras spinosum (Kossmat) and Desmoceras (Pseudouhligella) cf. japonicum YABE were obtained, seems to be located somewhat below this locality, in the same shale formation of the same valley. Similarly in Japan the species has been found in the middle part of the Cenomanian.

\section{Calycoceras boulei CoLlignon}

Pl. 20, fig. 1a, b; Text-figs. 31, 32

1937. Calycoceras (Metacalycoceras) boulei Collignon, Ann. Géol. Serv. Mines, Madagascar, p. 43, pl. 5, figs. 2, 2a, 3, 3a, 3b, 4, 4a, 4b; pl. 8, figs. 9, 10, 11.

1951. Calycoceras boulei, Wright \& WRIGHT, Palaeontogr. Soc., 1950, p. 26.

Types.-CollignoN (1937) established this species on at least four, syntypic, measured specimens, of which three were illustrated. Although $I$ have not seen the actual specimens, the largest of the figured specimens (ColligNoN, 1937, No. IV, pl. 5, fig. 4, 4a) is here designated as the lectotype.

Material.-Two specimens of different growth-stages from loc. UC. A-4852 (Coll. U. VALOV) are described here as the Californian examples of the present species. One of them UC. 36439 is illustrated (Pl. 20, fig. 1a, b; Text-figs. 31, 32). 
Measurements.-

\begin{tabular}{|c|c|c|c|c|c|}
\hline Specimen & Diameter & Height & Breadth $(\mathrm{B} / \mathrm{H})$ & Umbilicus (\%) & $\begin{array}{c}\text { Ribs } \\
\text { umb./vent. } \\
\text { per } 1 / 2 \\
\text { whorl }\end{array}$ \\
\hline $\begin{array}{l}\text { Lectotype (after } \\
\text { CoLLIGNON) }\end{array}$ & 121 & 53 & $(1.25)$ & (27) & $11 / 22$ \\
\hline UC. 36439 & \multicolumn{3}{|c|}{180 (preserved maximum) } & (29) & $10 / 23$ \\
\hline (costal) & 143.0 & 62.0 & $72.0(1.16)$ & $42.0 \quad(29)$ & \\
\hline $\begin{array}{l}\text { Smaller one from } \\
\text { UC. A-4852 }\end{array}$ & - & 40.0 & $25.5 \times 2(1.27)$ & - & \\
\hline
\end{tabular}

Description.-The larger specimen, from loc. UC. A-4852, which probably represents the adult shell, is about $180 \mathrm{~mm}$. in diameter. This is somewhat larger than the largest syntype (no. IV of CoLlignoN, 1937). Since many species of Calycoceras reachs fairly large size, the specimen from Madagascar, which Collignon considered as adult, may not be full-grown. Anyhow the difference of $180 \mathrm{~mm}$. as compared with $120 \mathrm{~mm}$. is not a great objection for concluding the specific identity.

About a quarter (in height) of the inner whorl is covered by the outer. The umbilicus is slightly less than 30 percent of the diameter of the entire shell. The smaller specimen, from loc. UC. A-4352, seems to have slightly narrower umbilicus than the larger one, but is too imperfectly preserved for accurate measurements. The proportion is, anyhow, approximately the same as that measured by COLLIGNON on the specimens of Madagascar.

The whorls are broader than high, broadest near the umbilical shoulder, steep on the umbilical wall, rounded at the umbilical shoulder, only slightly inflated on the flank in the earlier stages, moderately so in the later, and rounded on the venter. Thus the shape of the whorl is essentially the same as that described by COLLIGNON.

The ribs are normally alternately long and short, the shorter ones usually

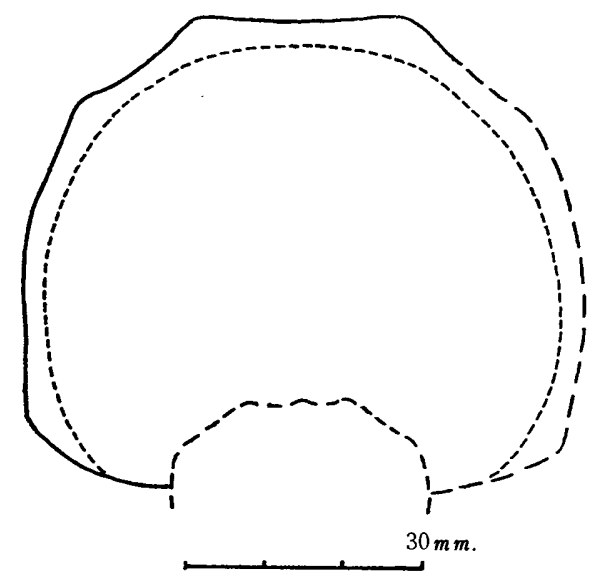

Fig. 31. Calycoceras boulei Collignon. Whorl-section of a specimen, UC. 36439, from loc. UC. A-4852, Hunters Creek, Lodoga Quadrangle, Glenn County. See Text-fig. 32 and also Pl. 20, fig. 1a, b. 
being intercalated but sometimes branching near the umbilical tubercles. They are strong, crowded on the inner whorls, and separated by interspaces as broad as, or somewhat broader than, the ribs themselves on the outer whorl. They cross the venter almost transversely, without decreasing strength. On the flank they are nearly rectiradiate, or slightly curved forward on the ventrolateral part. The umbilical tubercles are bullate, and on the internal mould not very prominent. The siphonal tubercles are only distinct on the early whorls, as seen on that of the smaller specimen of loc. UC. A-4852. They are obsolete on the outer whorl and finally disappear on the adult body whorl. The two pairs of the ventrolateral tubercles, considerably separated each other, are distinct, especially near the last part of the septate whorl, and persist up to the adult body whorl, although much weakened there. All of these characters of ornamentation observed on the Californian examples match the diagnostic features of $C$. boulei Collignon.

The sutures are also similar to those of Madagascar specimens, although minor differences apparently exist, owing perhaps to retouching of the latter. The saddle between $\mathrm{E}$ and $\mathrm{L}$ is massive and broad, $\mathrm{L}$ is not narrow on its stem, and shallower than E. Minor incisions show reducing tendency.

Remarks.-Calycoceras boulei CoLlignon resembles Calycoceras stoliczkai CoLlignon (1937, p. 48) in the depressed whorl, broadly rounded venter, relatively crowded, strong ribs, and pattern of sutures. They are so closely allied that I once doubted the separation of the two species, suggesting that the specimens of $C$. boulei might represent the shells of early growth-stages of C. stoliczkai. But now the distinction of the two species is clear. Even in the shell of the large size, as illustrated by one of the Californian examples, the two paired ventrolateral tubercles are fairly distinct. In $C$. stoliczkai, as exemplified by the specimens of India [Ammonites navicularis, STOLICZKA (non MANTELL), 1865, p. 73, pl. 39, figs. 2-4], Portugal [Acanthoceras naviculare, CHоFFAT, 1898, p. 72, pl. 4, fig. 6; pl. 6, figs. 1, 2], Japan [Calycoceras ef. stoliczkai, Matsumoto,

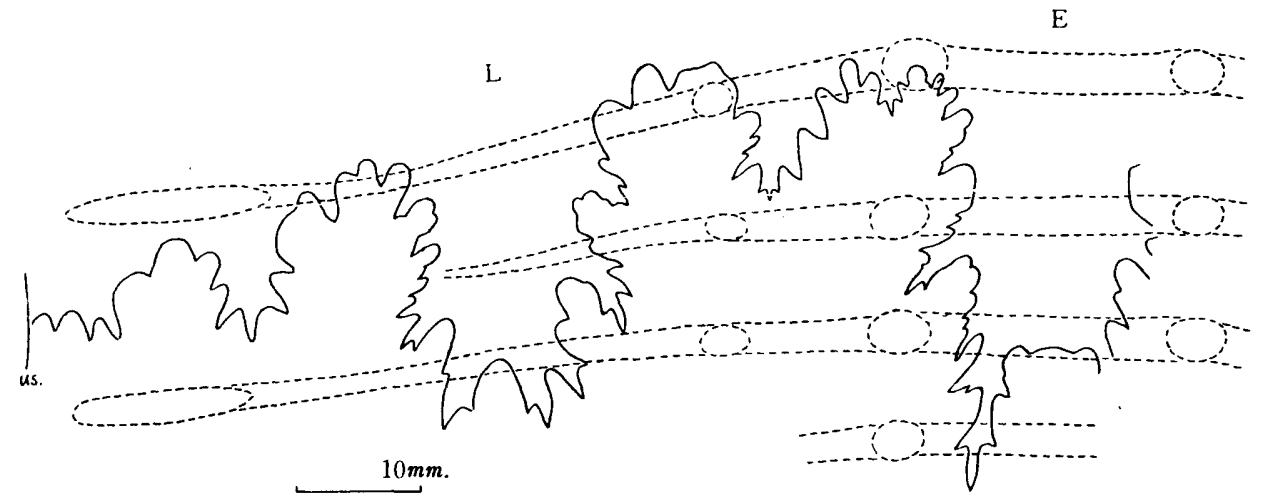

Fig. 32. Calycoceras boulei Collignon. External suture of a specimen, UC. 36439, from loc. UC. A-4852, Hunters Creek, Lodoga Quadrangle, Glenn County. Dotted lines indicate the position of the ribs and the tubercles. 
SAITo, and FUKADA, 1957, p. 19, pl. 6, fig. 1a, b], and California (described below) the ventrolateral, as well as siphonal tubercles are weakened or lost already in relatively early growth-stage, while the umbilical tubercles are remarkably prominent.

Matsumoto, Saito and Fukada (1957, p. 9) mentioned that the various species of Calycoceras can be sorted into three subgroups. It should be noted that the present species represents just the intermediate position between the subgroup of C. newboldi (Kossmat) and that of C. naviculare (MANTELL). Among the members of the newboldi-subgroup C. asiaticum (Јімво) (see Matsumoto, SAITo, and FuKADA, 1957, p. 11, pl. 1, fig. 1a-c; pl. 2, fig. 1a, b), from the middle part of the Cenomanian of Japan, is closest to $C$. boulei CollignoN in that the whorl is broadest near the umbilical margin, the ribs are relatively crowded on the inner whorl and not much distant even on the outer whorl, and that the two ventrolateral tubercles are fairly separated from each other. Of course, the former has more distinct tubercles, less depressed whorl than the latter, a polygonal, rather than rounded, whorl-section, and the sutures as deeply incised as those of $C$. newboldi (Kossmat) (1897, p. 4 [111], pl. 1 [12], figs. 2a, b, 3a-c; pl. 3 [14], fig. 2).

Occurrence.-Loc. UC. A-4852, Hunters Creek, Lodoga Quadrangle, Glenn County, west side of the Sacramento Valley. The locality is in the middle of the shale unit, with frequently intercalated sandstone. The unit is apparently below the Venado sandstone. In the same unit of the same general area, KüPPER (1956) reported some pelagic foraminifera of Upper Cenomanian aspect.

As has been proved by Wright and Wright (1951, p. 26), C. boulei ColligNON appears geologically earlier than C. naviculare (MANTELL) in the succession of England. CollignoN (1937, p. 60) originally assigned the stratigraphic position of Ankomaka, the type locality of $C$. boule $i$ in Madagascar, to the upper part of Lower Cenomanian. This is reasonable, but BESAIRIE and CoLlignoN (1956) has removed this species into their "zone of Acanthoceras rotomagense", Upper Cenomanian, along with $C$. naviculare MANTELL and C. stoliczkai ColligNON, without mentioning reasons. The isolated occurrence in California does not serve much for the solution of this question. In this respect further careful collecting in India, Japan, or other areas in the Indo-Pacific region is needed.

\section{Calycoceras stoliczkai COLLIGNON}

Pl. 21, fig. 1; Text-figs. 33-35

1865. Ammonites navicularis, Stoliczka (non Mantell), Mem. Geol. Surv. India, Pal. Indica, ser. 3, vol. 1, p. 73, pl. 39, figs. 2-4.

1897. Acanthoceras naviculare, Kossmat, Beitr. Pal. Geol. Oesterr.-Ung. Or., vol. 11, p. 11 [118].

1898. Acanthoceras naviculare, CHOFFAт, Recueil d'etudes paléontol. faune Crét. Portugal, vol. 1, p. 72, pl. 4, fig. 6; pl. 6, figs. 1, 2.

1937. Calycoceras (Metacalycoceras) stoliczkai Collignon, Ann. Géol. Serv. Mines, Madagascar, vol. 8, p. 48.

1957. Calycoceras ef. stoliczkai, Matsumoto, SaIto, and Fukada, Mem. Fac. 
Sci., Kyushu Univ., ser. D, vol. 6, p. 19, pl.6, fig. 1a, b.

1958. Calycoceras (Metacalycoceras) auspicium ANDERSON, Geol. Soc. Amer., Memoir 71, p. 243, pl. 20, fig. 8 only.

1958. Mantelliceras oregonense ANDERson, Geol. Soc. Amer., Memoir 71, p. 244, pl. 8, fig. 4, 4a; pl. 14, fig. 1, 1a.

Types.-COLlignON (1937, p. 48) established this species for the group represented by STOLICZKA's specimens of Ammonites navicularis (1865, p. 73, pl. 39, figs. 2-4) from the Ootatoor group of India. The larger one of the figured specimens of SToliczKA $(1865$, pl. 39, fig. 3) is here designated as the lectotype.

Material.-The examples of this species from California and Oregon, which I have studied, are as follows:

(1) A specimen, here figured (Pl. 21, fig. 1; Text-fig. 33), from loc. CAS. 2336, California, which had no specific name on the label (Coll. G. D. HANNA)

(2) A smaller specimen (Text-fig. 35), from the same loc. CAS. 2336, labelled “Eucalycoceras cf. oregonense ANDERSON" (Coll. G. D. HANNA)

(3) A specimen, from loc. CAS. 445, Oregon, which was designated as the holotype of Calycoceras (Metacalycoceras) auspicium ANDERSON (1958, p. 243, pl. 20, fig. 8) (Text-fig. 34)

(4) A specimer, from loc. CAS. 445, Oregon, which was designated as the holotype of Mantelliceras oregonense ANDERSON (1958, p. 244, pl. 14, fig. 1, 1a) (Coll. E. L. PACKARD)

(5) A specimen, from loc. CAS. 445-C, Oregon, which was figured as an example of Mantelliceras oregonense ANDERSON (1958, p. 244, pl. 8, fig. 4, 4a)

Measurements.-

(1)

(3) $\left\{\begin{array}{l}\text { (costal) } \\ \text { (intercostal) }\end{array}\right.$

(4)

Lectotype
Diameter Height Breadth (B/H) Umbilicus (\%) $\begin{gathered}\text { Ribs } \\ \text { umb./vent. } \\ \text { per } 1 / 2 \\ \text { whorl }\end{gathered}$ $157 \quad c .73 \quad$ c. $104.6(1.4) \quad$ c. $56 \quad$ (35) $11 / 22$

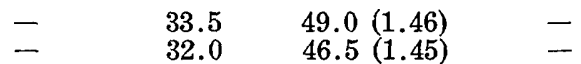

$84.5 \quad 39.5 \quad 59.0(1.49) \quad 27.5(32.5) \quad 8 / 16$

$100 \quad 41.0 \quad 62.3(1.52) \quad 31 \quad(31) \quad 8 / 16$

Description.-The species is characterized by a much depressed whorl, a broadly rounded venter, strong ribs which are alternately long and short, prominent umbilical tubercles, and reducing ventrolateral and siphonal tubercles which are much weakened or completely lost on the outer whorl.

The coarseness or density of the ribs is somewhat variable. This is exemplified by both the Indian and American specimens. The fourth specimen in the above list from Oregon, the holotype of Mantelliceras oregonense ANDERsoN (1958, pl. 14, fig. 1, 1a), is very similar in the coarseness and strength of the ribs to the lectotype of Calycoceras stoliczkai (SToLICZKA, 1865, pl. 39, fig. 3), from India, which STоLICZKA illustrated as a relatively coarsely ribbed example. The fifth specimen, another example of $M$. oregonense ANDERSON (1958, pl. 8, fig. 4, 4a) has the ribs as crowded as another of SToliczKA's examples (STo- 


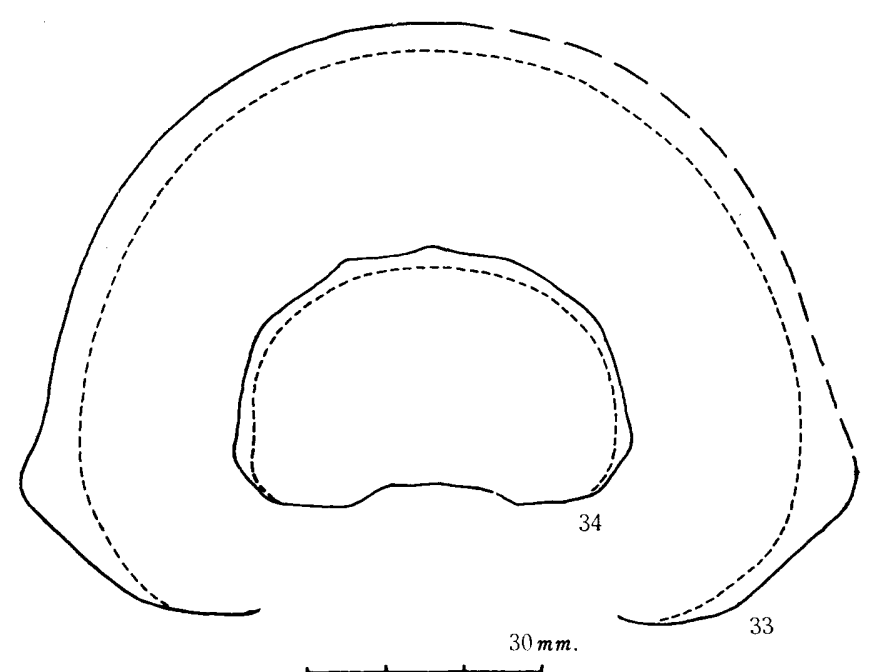

Figs. 33, 34. Calycoceras stoliczkai Collignon. Whorl-sections.

33. A specimen, partly restored, from loc. CAS. 2336, west of Logan Ridge, Lodoga Quadrangle, Colusa County. See Pl. 21, fig. 1 for side view.

34. Another example from loc. CAS. 445, Oregon [ =holotype of Calycoceras auspicium ANDERSON, 1958, Pl. 20, fig. 8].

LICZKA, 1865, pl. 39, fig. 2). In these and other features Mantelliceras oregonense ANDERSON is proved to be specifically identical to Calycoceras stoliczkai ColligNON.

The first specimen, figured in this paper (Pl. 21, fig. 1; Text-fig. 33), and the second, both from California, have fairly crowded, numerous ribs even on the outer whorl. The third specimen similarly has relatively numerous ribs, which are apparently narrow on the internal mould. This has traces of siphonal and ventrolateral tubercles, which are shown as very weak elevations or angulations superimposed on the ribs on its posterior part (Text-fig. 34) but are lost on the anterior part. It was designated as a holotype of Calycoceras (Metacalycoceras) auspicium ANDERSON (1958, p. 243, pl. 20, fig. 8), but is nothing but an example of Calycoceras stoliczkai Collignon. The paratype of C. auspicum ANDERSON (1958, pl. 20, fig. 9) has no affinity with Calycoceras, but is an immature shell of Collignoniceras cf. woollgari (MANTELL) (see below).

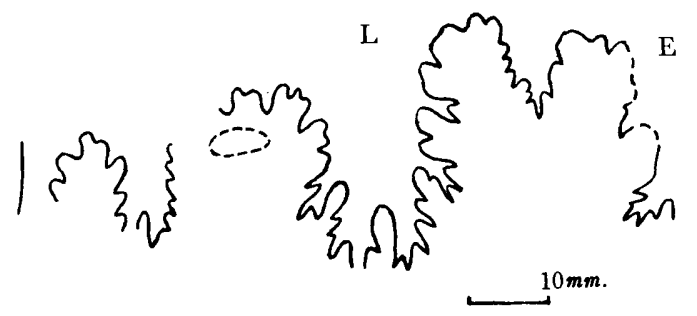

Fig. 35. Calycoceras stoliczkai Collignon. External suture on a smaller specimen from loc. CAS. 2336, Lodoga Quadrangle, Colusa County. A dotted circle indicates the position of the umbilical tubercle. 
The suture, as drawn in this paper (Text-fig. 35 for the second specimen), is of the same type as that of Calycoceras boulei Collignon (see the preceding description).

Remarks.--I have already mentioned the affinity and distinction between Calycoceras stoliczkai COLLIGNON and $C$. boulei Collignon (see the preceding description).

C. stoliczkai Collignon is also closely allied to C. naviculare (MANTELL). The latter species has often been misinterpreted, but has recently been clearly redefined (see Wright and Wright, 1951, p. 26 ; Matsumoto, Saito, and Fukada, 1957, p. 9). Although the variations of the two species may slightly overlap, the former has on the average more depressed whorls ( $b / h$ being 1.4-1.5 as compared with $1.2 \pm 0.1$ ), more elevated ribs, and stronger and more equally prominent umbilical tubercles, than the latter. On the outer whorl of $C$. naviculare (MANTELL) the ribs become very distant and sometimes the ventrolateral tubercles are rejuvenated. Such features have not been recognized on the outer whorls of $C$. stoliczkai ColligNon. The suture may also be fairly variable as in many species of the Acanthoceratidae. The two species have essentially the same type of sutures, but the reducing tendency of the minor incisions seems to be more noticeable in $C$. naviculare than in C. stoliczkai and $C$. boulei. In this connection I doubt the distinction between Calycoceras obrieni Young (1957, p. 1171, pl. 150, figs. 1-4; text-fig. 1f, h) and C. naviculare (MANTELL).

Occurrence.-The two specimens from loc. CAS. 2336, in Lodoga Quadrangle, Colusa County, California. The locality is within a shaly unit on the eastern flank of an anticline and is close to KÜPPER's (1956) locality of Upper Cenomanian foraminifera. The three specimens from Oregon are not stratigraphically well allocated. Their rock matrices are calcareous sandstones, which are much different in color, coarseness, and other aspects from those of the Turonian fossils from the same general area.

The specimens from southern Indian were ascribed by Kossmat (1897) primarily to the Middle, and also partly to the Upper, Ootatoor group. BESAIRIE and Collignon (1956) listed C. stoliczkai under the zone of Acanthoceras rhotomagense, in the upper part of the Cenomanian in Madagascar. The Japanese specimens comparable to this species came from the "middle part of the Paleogyliakian", approximately upper-middle part of the Cenomanian (MATSUMoto, SAITo, and FUkAdA, 1957, p. 20). From the upper part of the Paleogyliakian in Hokkaido $C$. cf. naviculare has recently been obtained.

\section{Genus Acanthoceras NeUmayr, 1875}

Type-species.-Ammonites rhotomagensis DeFrance in BRongniart, 1822. Generic diagnosis.-See Matsumoto, Saito, and Fukada, 1957, p. 32.

Remarks.-While examples of Calycoceras are not uncommon in California and Oregon, those of Acanthoceras are very rare. The situation is similar to that in Japan.

The species which have strong, ventrolateral horns on the outer whorl are 
intimately connected with the typical group of $A$. rhotomagense, through certain transitional species. They occur mostly in the Upper Cenomanian as do $A$. rhotomagense and its allies. They are very common in the Western Interior and Gulf Coastal provinces but are not confined to this part of the world. Therefore it is unwise to separate the horned group of species from Acanthoceras.

Acanthoceras whitei, nom. nov.

Pl. 22, fig. 1a-c; Pl. 39, fig. 1; Text-fig. 36

1865. Ammonites rhotomagensis, Stoliczka pro parte (non Defrance in Brongniart, 1822), Mem. Geol. Surv. India, Pal. Indica, ser. 3, vol.1, p. 68 , pl. 35 , fig. 3 .

1889. Ammonites turneri, White (non Sowerby, 1825), Bull. U. S. Geol. Surv., no. 51, p. 26 , pl. 5 , figs. $1,2$.

1897. Acanthoceras turneri, Kossmat, Beitr. Pal. Geol. Oesterr.-Ungarns Or., vol. 11, p. 2 [109], pl. 1 [12], fig. 1a, b; pl. 3 [14], fig. 3.

1924. Acanthoceras turneri, Hanna, Proc. Calif. Acad. Sci., 4 ser., vol. 13, p. 156.

? 1928. Acanthoceras n. sp. aff. A. turneri, AdKins, Univ. Texas Bull. 2838, p. 246, pl. 30, figs. 3 , 4.

1958. Calycoceras (Eucalycoceras) turneri, ANDERSon, Geol. Soc. Amer., Memoir 71, p. 243.

Holotype.-USNM. 20121, the original specimen of WHITE (1889, pl. 5, figs. 1, 2), here refigured (Pl. 22, fig. 1a-c; Pl. 39, fig. 1; Text-fig. 36).

Material.-I have not recognized any other specimens from California which could be referred to this species. I had an opportunity of studying ADKINs' specimen from loc. BEG. 2410, Texas (AdkINs, 1928, pl. 30, figs. 3, 4) (Text-fig. 37 in this paper).

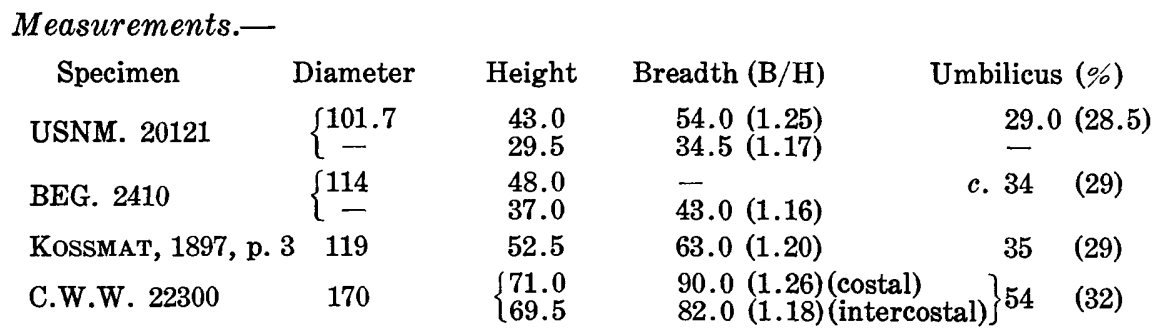

Diagnosis.-The shell is of moderate size. The whorls grow fairly rapidly, with little overlapping. The umbilicus is slightly less than 30 percent of the shell-diameter. The whorl is broader than high, with flat, subparallel but slightly convergent, flanks, a broadly arched venter, steep umbilical walls and subangular umbilical shoulders.

The outer, probably adult, whorl is ornamented with rectiradiate, distant, equally long ribs, which are broadened and weakened on the venter, rounded ventrolateral tubercles, and prominent umbilical tubercles. The ventral tubercles in three rows are much weakened, being completely obsolete on the last part of the whorl.

The septate immature whorl is ornamented with slightly prorsiradiate, 
alternately long and short ribs, which are less distant than the ribs of the adult whorl, fairly crowded on the venter, and are of moderate elevation and breadth. The tubercles are fairly strong, but the medioventral tubercles begin to be weakened earlier than others. The ventrolateral tubercles are conical (not clavate); the prominent umbilical tubercles are well separated from the umbilical margin.

The suture is less perfectly exposed on the holotype, but on the Indian example it was well described and illustrated by Kossmat (1897, p. 3 [110], pl. 3 [14], fig. 3).

Remarks.-Because Ammonites turneri WHITE, 1889 is a homonym of Ammonites turneri Sowerby, 1825, another name is necessary for WHITE's species, as HANNA (1924, p. 156) correctly stated. The situation is not changed even if the twc species were subsequently referred to the distinct genera Acanthoceras NeUMAYR, 1875 and Euasteroceras DoNovan, 1953. I propose here for WHITE's species the new name of Acanthoceras whitei.

I agree with Kossmat in regarding the Indian example (Kossmat, 1897, p. 2 [109], pl. 1 [12], fig. 1a, b; pl. 3 [14], fig. 3) as being conspecific with the Californian holotype. This species is evidently allied to Acanthoceras rhotomagense (DEFRANCE in BRONGNIART, 1822) (see SHARPE, 1855, p. 33, pl. 16, figs. $2 \mathrm{a}, \mathrm{b}, 3 \mathrm{a}, \mathrm{b}$ only), the type-species of Acanthoceras, in the subquadrate whorlsection, little involution, equally long ribs on the adult whorl, and the pattern

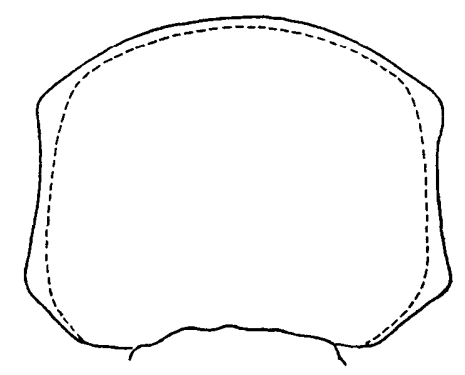

$$
\sum^{20 m m}
$$

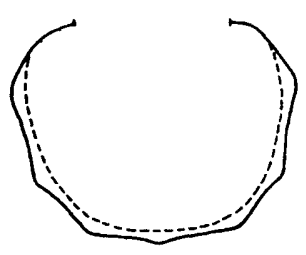

Fig. 35. Acanthoceras whitei nom. nov. Whorl-section of the holotype, USNM. 20121, from Curry's Canada, Mt. Diablo area. See PI. 22, fig. 1a-c and Pl. 39, fig. 1 for other views. 


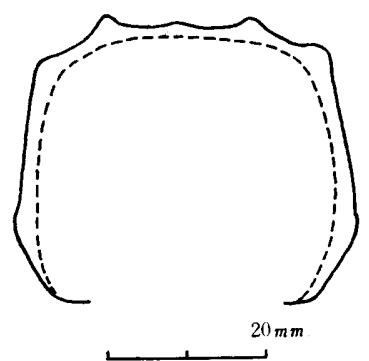

Fig. 37. Acanthoceras cf. rhotomagense (DEFRANCE). Whorl-section of ADKINs' specimen of “Acanthoceras n. sp. aff. A. turneri WHITE”, from loc. BEG. 2410, Eagle Ford shale, Texas.

of suture. It should obviously be referred to Acanthoceras, and is certainly not a Eucalycoceras. Its distinction from A. rhotomagense is, as Kossmat (1897, p. 4 [111]) rightly remarked, its broader whorl, more persistent alternately long and short ribs, and the earlier disappearance of the ventral, paired tubercles. Its broadly arched, instead of flattened venter may be another criterion, but this is not clear, because the outer whorl of the holotype is somewhat deformed.

The specimen, from loc. BEG. 2410, Texas, described as Acanthoceras n. sp. aff. A. turneri WhIte by Adkins (1928, p. 246, pl. 30, figs. 3, 4) (Text-fig. 37 in this paper) is indeed close to the present species, but the clavate, paired ventral tubercles persist to a later growth stage and the longer ribs are more numerous than the slightly shorter ones on the shell of $114 \mathrm{~mm}$. in diameter. Therefore, it is very close to A. rhotomagense.

WRIGHT showed me an interesting specimen in his collection (C. W. W. 22300 ) from England. It is close to $A$. rhotomagense, but is also similar to $A$. whitei in its mode of ribbing, broad whorl, and broadly arched venter.

Occurrence.-The holotype came from Currys Canada, Mount Diablo area, California. Its stratigraphic position is not precisely known. The matrix of the specimen is a dark greenish, bluisìi, calcareous sandy siltstone, containing some carbonaceous fragments and small snails.

This species is rare according to our present knowledge, but it seems to have been widespread, because it occurs in the middle Ootatoor group of southern India. Allied forms are from the Eagle Ford shale (flag member) on BeltonTemple highway, Texas and from the Lower Chalk of Osmington, Dorset, England.

Acanthoceras sp.

Pl. 25, fig. 2; Text-fig. 38

Compare.-

1857. Ammonites cenomanensis, ShARPE (non D'ARchiac). Palaeontogr. Soc. (1856), p. 37, pl.17, fig. 1a, b.

1926. Acanthoceras sherborni Spath, Geol. Mag., vol.63, p. 82.

1928. Acanthoceras n. sp., AdKIns, Univ. Texas Bull. 2838, pl. 27, fig. 2.

1942. Acanthoceras pepperense Moreman, Jour. Pal., vol.16, p. 204, pl.32, fig. 5 ; text-fig. $2 \mathrm{~m}$. 


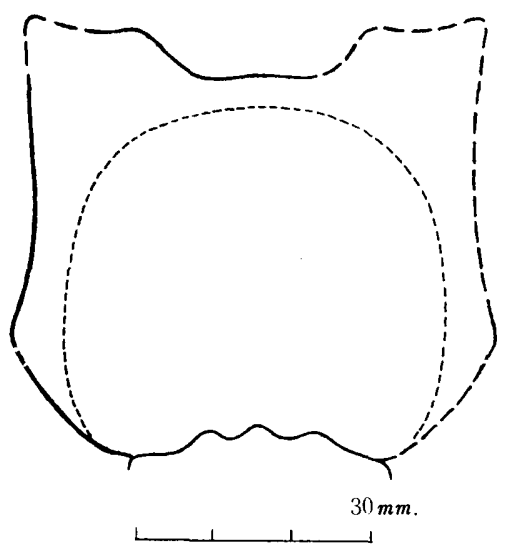

Fig. 38. Acanthoceras sp. Whorl-section, partly restored, of a specimen from loc. CAS. 2324, Lower Waltham formation, west of Coalinga, Fresno County. See Pl. 25, fig. 2 for the side view.

Material.-Only a single, fragmentary, outer whorl, from loc. CAS. 2324 (Coll. G. D. HANNA).

Description.-The fragmentary outer whorl has impressions of the five rows of ventral tubercles (including ventrolateral ones) of the next inner whorl. The outer whorl itself has equally long, distant ribs with prominent, bullate tubercles somewhat above the umbilical margin and horned ventrolateral tubercles. The horn is developed from the enlarged lower ventrolateral one absorbing the upper ventrolateral one. It seems to stretch straight upwards rather than obliquely outward. The intercostal section is subquadrate, slightly broader than high, as the restored figure (Text-fig. 38) shows.

Remarks.-Although the specimen is fragmentary, it is noteworthy, because it represents a horned Acanthoceras occurring in California and because it is close to the species already known outside the Pacific Coast.

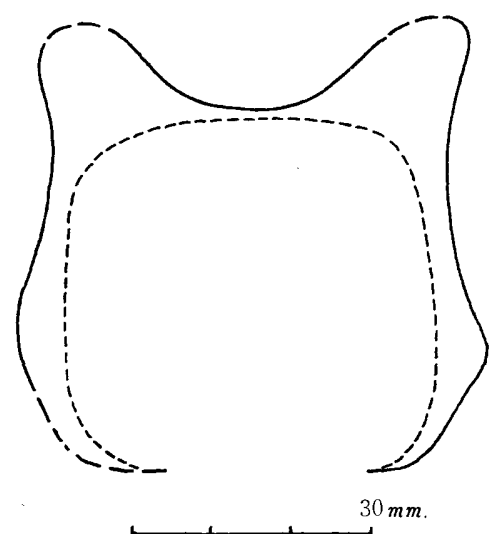

Fig. 39. Acanthoceras pepperense MOREMAN. Whorl-section of the holotype, BEG. 19803, from the Tarrant member of the Eagle Ford shale, Texas. 
In the shell-form and the ornamentation the described specimen of California closely resembles the outer whorl of Acanthoceras pepperense MOREMAN (1942, p. 204, pl. 32, fig. 5 ; text-fig. $2 \mathrm{~m}$ ) (Text-fig. 39 of this paper), from the Tarrant formation of the Eagle Ford group of Texas. In addition to the holotype, BEG. 19803, there are several specimens, from loc. BEG. 2411 and BEG. 2410, the flag member of the Eagle Ford group, which are best referred to $A$. pepperense. The one figured by ADkins (1928, pl. 27, fig. 2) as "Acanthoceras n. sp.", from loc. BEG. 2410, may be one of them. From the observation of all the available specimens I conclude that $A$. pepperense is fairly close to an upright-horned species of Acanthoceras, which occurs somewhat below the zone of Acanthoceras amphibolum and is considered by COBBAN (personal conversation) to be new, and in my opinion is closely related to Acanthoceras cornigerum CRICK (1907, p. 207, pl. 13, fig. 1, 1a; Matsumoto, Saito, and Fukada, 1957, text-fig. 5), from Zululand, South Africa. On the other hand, the less strongly horned, earlier whorl of A. pepperense is almost indistinguishable from the British Lower Chalk A. sherborni SPATH (1926, p. 63) [=Ammonites cenomanensis, SHARPE (non D'ARCHIAC), 1857, p. 37, pl. 17, fig. 1a, b], but for a slightly narrower umbilicus.

There is another Californian specimen which should be taken into consideration. It is an imperfectly preserved ventral portion of a septate whorl, from loc. LSJU. 2958, Walthan Creek of Coalinga Quadrangle, Lower Waltham formation (Coll. S. W. MULLER). It resembles A. sherborni but is closer to Acanthoceras evolutum SPATH (1926, p. 82) [=Ammonites sussexiensis, SHARPE (non MANTELL), 1855, p. 34, pl. 15, fig. 1] in the ornamentation on the venter.

Occurrence.-Loc. CAS. 2324, north side of Walthan Creek, presumably Lower Waltham formation, Coalinga Quadrangle, Fresno County, west side of the San Joaquin Valley.

Genus Romaniceras SPATH, 1923

Type-species.-Ammonites deverianus D'ORBIGNY, 1841, by original designation.

Synonym.-Kossmatia, YABE, 1927 (non UHLIG, 1907) (see WRIGHT and MATSUMOTо, 1954, p. 128).

Generic diagnosis.-See Matsumoto, Saito, and Fukada, 1957 (Mem. Fac. Sci., Kyushu Univ., ser. D, vol. 6, no. 1), p. 21.

Remarks.-Romaniceras is proved to be a multituberculate derivative from Calycoceras, while Acanthoceras gives rise to Yubariceras (see MATsumoto et al, 1957, p. 22 and p. 26 ).

In California there are fairly well preserved specimens of Romaniceras, which I identify with the two species, $R$. deverioide (DE Grossouvre) and $R$. sp. aff. $R$. pseudodeverianum (ЈIMBO). There is another undeterminable species, which are probably distinguished from these two. 
Romaniceras deverioide (DE GROSSOUVRE)

Pl. 25, fig. 1a-c; Pl. 26, fig. 1a-c; Pl. 28, fig. 1a, b; Pl. 29, fig. 4a-c; Text-figs. 40-44

1889. Ammonites deverioides De Grossouvre, Bull. Soc. Géol. France, 3 ser., vol. 17, p. 524, pl. 12, figs. $1,2$.

1897. Ammonites deverioides, Peron, Mém. Soc. Géol. France, Paléont., no. 17, p. 21, pl. 1, figs. 2,3 .

1931. Romaniceras loboense AdKINs, Univ. Texas Bull., no. 3101, p.44, pl. 2, figs. 1,21 ; pl. 3 , fig. 5 .

1937. Acanthoceras deverianum, BASSE (pro parte) (non D'ORBTGNY), Hautcomm. Repub. franç. Syrie Lyban, Notes et mém. 2, p. 180, pl. 8, fig. 1a, b.

1939. Romaniceras deverioides, Collignon, Ann. Géol. Serv. Mines, Madagascar, vol. 10, p. 37 .

1958. Mantelliceras conquistador ANDERSON, Geol. Soc. Amer., Memoir 71, pl. 245, pl. 15, fig. 2.

1958. Mantelliceras aff. conquistador ANDERSON, Geol. Soc. Amer., Memoir 71, p. 245, pl. 14, fig. 2 .

1958. Mantelliceras aff. conquistador ANDERSon, Geol. Soc. Amer., Memoir 71, p. 245 , pl. 14, fig. 2 .

1958. Romaniceras hesperium Anderson, Geol. Soc. Amer., Memoir 71, p. 246, pl. 23, fig. 1, 1a.

Lectotype.-DE Grossouvre (1889) established this species on syntypes. The figured specimen (DE GRossouvre, 1889, pl. 12, figs. 1, 2) is here designated as the lectotype. It is now preserved at the Ecole de Mines, Paris and its plaster cast has been kindly sent to Kyushu University (GK. H9139) through Dr. J. SoRNAY. According to his information, it came from one of the numerous quarries in the "tuffeau" in the neighborhood of Bourré (Loir et Cher), France.

Material.-The following, relatively well-preserved specimens are the Californian examples of the present species.

Three measured and illustrated specimens, UC. 32251 ( $\mathrm{Pl}$. 25, fig. 1a-c; Text-fig. 41), UC. 15748 (Pl. 26, fig. 1a-c; Text-fig. 43), and UC. 33831 (Text-fig. 44a, b), from loc SOC. K-225 (Coll. M. V. KIRK)

Two measured and illustrated specimens, CIT. 3727 (Pl. 28, fig. 1a, b; Text-fig. 42) and UCLA. 28796 (Pl. 29, fig. 4a-c), and also three other measured specimens from loc. CIT. 1345 (Coll. W. P. PopenoE \& Carl A HLROTH)

A specimen from loc. CIT. 1190 (Coll. W. P. Popenoe \& Carl Ahlroth)

A specimen, GK. H7048, from loc. TM. 2003 [=LSJU. 3290] (Coll. W. P. Popenoe \& T. Matsumoto)

Three specimens of different growth-stages in the collection of USGS. Menlo Park, from Swede Creek, Redding area (Coll. W. P. Popenoe \& R. W. BROWN)

ANDERSON's (1958, p. 245, pl. 14, fig. 2; pl. 15, fig. 2; pl. 23, fig. 1, 1a) specimens from loc. CAS. 31230 and CAS. 31231 [=CIT. 1345]

I have also studied the Texas specimens from loc. BEG. 2612 in comparison with the Californian ones. 


\begin{tabular}{|c|c|c|c|c|c|c|}
\hline Specimen & Diameter & Height & Breadth & $(\mathrm{B} / \mathrm{H})$ & Umbilicus & $(\%)$ \\
\hline Lectotype & 122.5 & 51.8 & 62.0 & $(1.19)$ & 38.3 & $(31)$ \\
\hline$\prime \prime(1 / 2$ vol. earlier $)$ & 98.2 & 43.0 & 52.5 & $(1.22)$ & 30.0 & $(31)$ \\
\hline$R$. loboense (holotype) & - & 73.0 & 83.6 & $(1.14)$ & - & \\
\hline Another from BEG. 2612 & - & 55.5 & 66.0 & $(1.18)$ & - & \\
\hline CIT. 3727 & c. 125 & 54.3 & 64.3 & $(1.20)$ & 29.7 & $(32)$ \\
\hline$\prime \prime \quad$ (earlier) & c. 90 & 38.5 & 47.8 & $(1.23)$ & - & \\
\hline UCLA. 28796 & 73.6 & 37.3 & 46.0 & $(1.23)$ & 21.8 & $(30)$ \\
\hline Another from CIT. 1345 & 54.4 & 24.0 & 29.5 & $(1.22)$ & 16.0 & 29) \\
\hline$\prime \prime$ & - & 31.8 & 38.3 & $(1.20)$ & - & \\
\hline$\prime \prime$ & - & c. 70 & c. $42.5 \times 2$ & $(1.21)$ & - & \\
\hline UC. 32251 (costal) & 89.0 & 38.5 & 51.5 & $(1.33)$ & 25.7 & $(29)$ \\
\hline "I (intercostal) & - & 36.8 & 44.0 & $(1.19)$ & - & \\
\hline UC. 15748 (costal) & - & 54.6 & 74.5 & $(1.36)$ & - & \\
\hline$"$ (intercostal) & - & 52.2 & 66.0 & $(1.26)$ & - & \\
\hline UC. 33831 & 172.5 & 67.5 & 87.0 & $(1.28)$ & 55.5 & $(32)$ \\
\hline$\prime \prime(1 / 2$ vol. early $)$ & - & 44.5 & 58.1 & $(1.30)$ & - & \\
\hline USGS. Menlo Park & - & 31.0 & 37.0 & $(1.19)$ & - & \\
\hline " (another) & - & 44.7 & 53.7 & $(1.20)$ & - & \\
\hline GK. H 7048 & - & 54.5 & 71.7 & $(1.31)$ & - & \\
\hline
\end{tabular}

Diagnosis.-The shell is thickly discoidal, relatively evolute, and moderately widely umbilicate; the umbilicus being 28-32 percent of the shell-diameter. The full-grown shell may be considerably large. The whorl is broader than high, moderately to broadly rounded on the venter, fairly inflated on the flank, and steep and high on the umbilical wall.

The ribs are strong and widely spaced especially on the outer whorl. They are nearly rectiradiate on the sides, but may show a very broadly convex curve on crossing the venter. The secondary ribs are less numerous than the primary ribs. The tubercles are in eleven rows; they are generally strong but the siphonal one is weakened on the outer whorl; the three tubercles on the venter are clavate; the lower ventrolateral one is not so clearly clavate as the upper; the upper lateral one is conical and normally weaker than the adjacent two; the lower lateral the most prominent and situated below the mid-flank; the umbilical one bullate and sometimes weakened.

The suture is of typical Romaniceras pattern. The saddle between $\mathrm{E}$ and $\mathrm{L}$ is subrectangular in general outline, cut with considerably deep and narrow lobules. The saddle between $\mathrm{L}$ and $\mathrm{U}_{2}$ is massive. The external lobe $(\mathrm{E})$ is the deepest. The lateral lobe (L) is extremely asymmetric.

Variation.-The proportion between height and breadth of the whorl changes by individuals and also by growth-stages, ranging from $10: 11.4$ to $10: 13.6$. In correlation with this variation the venter is moderately to broadly rounded.

Generally the ribs become distant on the outer whorl, being separated by much wider interspaces than the ribs themselves. The distance and, accordingly, the number per whorl, of the ribs vary also by individuals.

The ribs are moderately broad and elevated, crossing the venter without interruption, but on a few specimens (obtained from the same locality as the 
strongly costate ones) they are less elevated than in the usual examples. The feature may change also by the mode of preservation; the internal mould shows a weaker ornament than the actual shell.

The tubercles on the rib are nearly equidistant in the normal case. The lectotype, the illustrated specimen of DE GRossouvre (1889, pl. 12, figs. 1, 2), is rather peculiar in that the two ventrolateral tubercles approach each other (Text-fig. 40a, b). I do not regard this as a specific character, because Dr. SORNAY, in reply to my inquiry, has clarified a fact that in many specimens from Bourré, the type locality, the two ventrolateral tubercles are more separated than in the lectotype and that the spacing of the tubercles is roughly equidistant, showing minor variation even on the same individual. The same feature is observable on the American specimens. On some specimens from California and Texas the distance between the two ventrolateral tubercles are slightly wider than that between the lower ventrolateral and upper lateral ones. Even an asymmetric configuration of the tubercles is occasionally seen, as is indicated by illustration (Pl. 29, fig. 4a-c; Text-fig. 44a, b). This is abnormal, but probably confused ANDERSON and led him to refer some of the examples of the present species to Mantelliceras ( $M$. conquistador ANDERSON, 1958, p. 245, pl. 15, fig. 2; pl. 14, fig. 2).

Remarks.-I agree with CollignoN (1939, p. 38) in separating $R$. deverioide (DE GRossouvre) from Ammonites ornatissimus SToliczKA (1865, p. 75, pl. 40). Kossmat (1897, p. 16 [123], text-figs. 2-4) did not compared GrossouvrE's illustrated specimen with StoliczkA's. His specimen from Ruillé (Sarthe), France is probably identical with Ammonites deverioides var. armata DE GRossouvRE (1889, p. 525), which could be synonimized with Ammonites ornatissimus STOLICZKA. Unfortunately the type of armata, which was not illustrated, is now missing and that of ornatissimus is imperfectly preserved. Therefore I cannot decide the synonymy, but I suggest that they may be referred to Yubariceras.

Ammonites deverioides var. inermis DE GRossouvRE (1889, p. 525), which received another name, Acanthoceras bizeti DE GRossouvRe (1901, p. 780), is in my opinion distinctly separable from $R$. deverioide. The plaster cast of the probably original specimen of inermis, from the Turonian of Bourré (Loir \& Cher), France, has been kindly presented to Kyushu University (GK. H9140) through Dr. J. SoRNAY. It has more compressed whorl and more crowded ribs than the lectotype of $R$. deverioide; its tubercles are very weak or almost obsolete on its flattened flanks but are distinct and approximated on its narrowly rounded venter. In other words this species is rather allied to Eucalycoceras (?) shastense (REAGAN) to be described below.

If Romaniceras deverioide (DE GROSSOUVRE) is amended as above and if its variation is recognized as described in the preceding paragraph, the Californian examples linder consideration are reasonably identified with this species.

Romaniceras loboense ADKINs (1931, p. 44, pl. 2, figs. 1, 21; pl. 3, fig. 5) is in my opinion specifically identical with $R$. deverioide (DE GROSSOUVRE). Its 

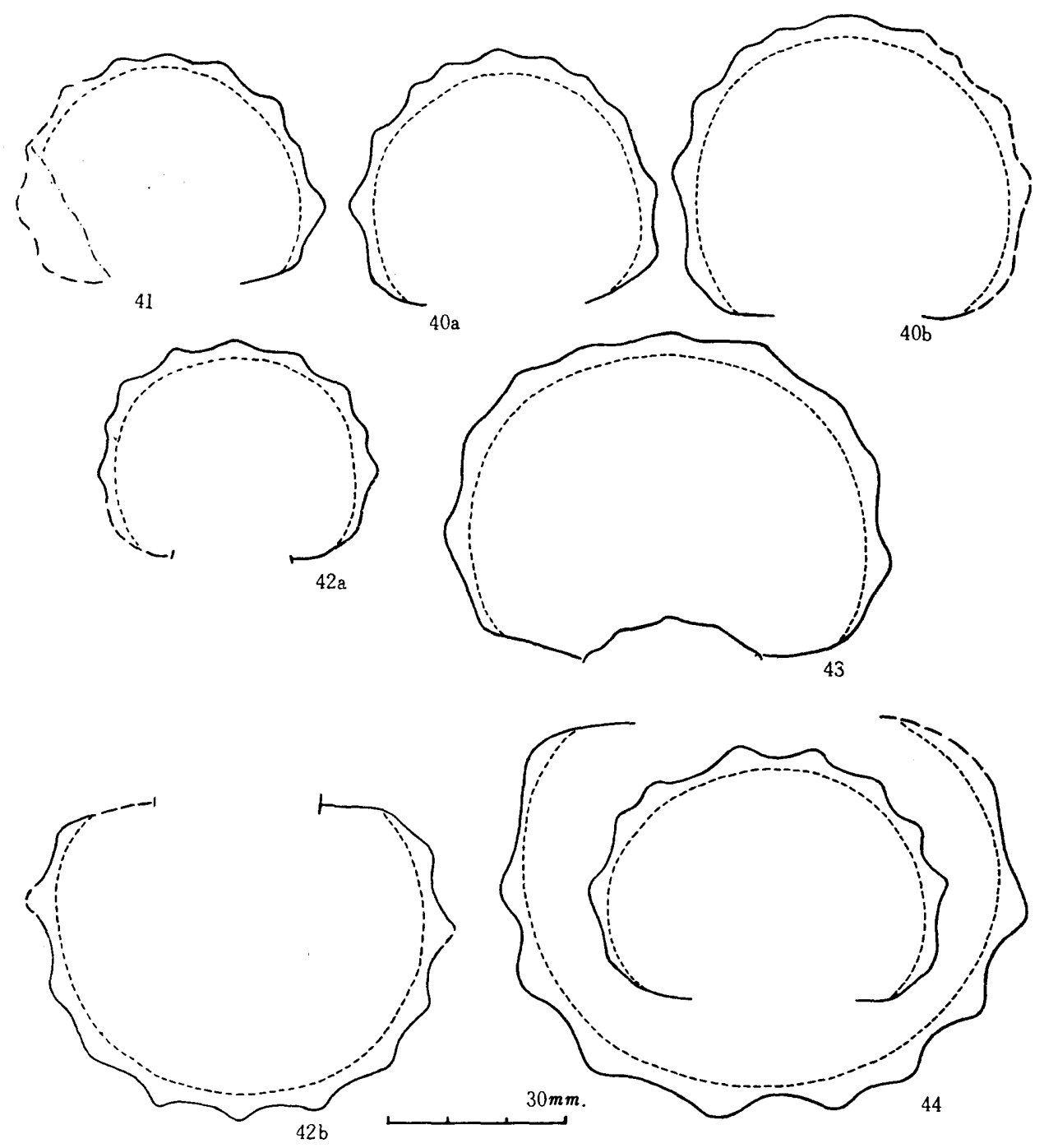

Figs. 40-44. Romaniceras deverioide (DE GROSSOUVRE). Whorl-sections of five specimens.

40. Two sections $(a, b)$ of a plaster cast of the holotype, from a quarry in the "tuffeau" in the neighborhood of Bourré (Loir et Cher), Middle Turonian, France.

41. UC. 32251, from loc. SOC. K-225, Swede Creek, Redding area, Shasta County. See Pl. 25, fig. 1a-c for other views.

42. CIT. 3727, from loc. CIT. 1345, Swede Creek, Redding area. See Pl.

28 , fig. 1a, b for other views.

43. UC. 15748, from loc. SOC. K-225, Swede Creek, Redding area. See Pl.

26 , fig. $1 \mathrm{a}-\mathrm{c}$ for other views.

44. UC. 33831 from loc. SOC. K-225, Swede Creek, Redding area. 
holotype, from loc. BEG. 2612 in northwest Texas, is quite identical with the normal examples from California, being within the range of variation of $R$. deverioide. Its shell-form is almost indistinguishable from that of the lectotype of $R$. deverioide. ADKINs (1931, pl. 2, fig. 21) illustrated in lateral view only a half of the fragmentary whorl of his type specimen. The other half was measured by him and its cross section is illustrated here (Text-fig. 45). Unfortunately ADKins' illustration and description failed to show clearly the eleven (instead of nine) tubercles, among which the lower lateral one on the longer rib is the most prominent. "The faint, bullate, mid-flank tubercles" of ADKINs' description is discernible only on the shorter ribs. I have recognized another example of this species in the collection from the same loc. BEG. 2612. Romaniceras cumminsi ADKINS (1931, p. 43, pl. 3, fig. 6), which has page priority over $R$. loboense ADKINs, might be identical with the present species, but I cannot give accurate remarks on it, because its holotype is missing.

A specimen from loc. UC. B-2040, in a conglomerate of the Venado formation equivalent crossing Putah Creek, west side of the Sacramento Valley, has eleven rows of tubercles, but its ribs and tubercles are weaker and its whorl is more rounded than $R$. deverioide. It may represent a different species from $R$. deverioide, but I cannot give a specific name, because only a single, poorly preserved specimen is at my disposal.

Occurrence.-Locs. CIT. 1345, CAS. 3123, CAS. 31230, LSJU. 3290 [=TM. 2003], and SOC. K-225, close to one another, on Swede Creek (French Creek on map of Milville Quadrangle), Redding area and loc. CIT. 1190, north of Bella Vista, Redding area. The last locality is referred to the lower part of Member II of PoPENoE. The localities on Swede Creek were once assigned to Member IV, but the area is so isolated that the assignement is doubtful. They may be timestratigraphically about the same level as CIT. 1190.

In France the type locality of Romaniceras deverioide (DE GRossouvRE)

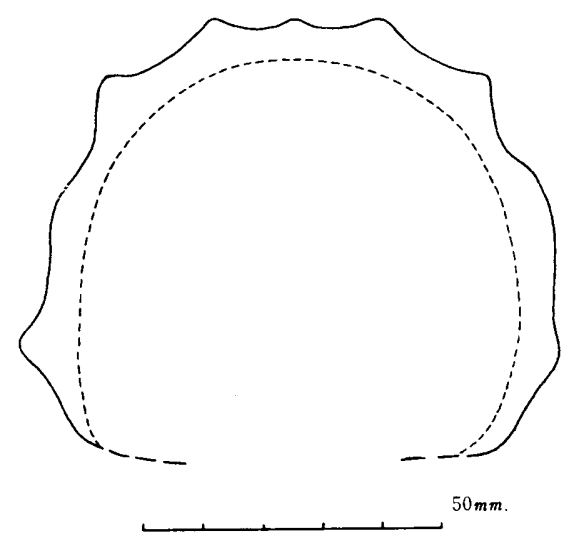

Fig. 45. Romaniceras deverioide (DE GROSsouvRE). Whorl-section of an example from loc. BEG. 2612, Chipsa Summit, Eagle Ford Shale. This is the holotype of Romaniceras loboense ADKINS, 
was at first referred to the upper part of the Ligerian (Lower Turonian). According to DE GRossouvRE's later work (1901, p. 780) the species is always accompanied with Collignoniceras woollgari (MANTELL). J. SoRNAY has informed me (a letter dated December 19, 1957) that the "tuffeau" in the neighbourhood of Bourré (Loir et Cher), from which the original specimens came, is Middle Turonian.

The type locality of Romaniceras loboense ADKINS is BEG. 2612, Chispa Summit, in western Texas, "zone 3" of the equivalent of the Eagle Ford group. Among the associated species of BEG. 2612, Pseudoaspidoceras (?) sp. of ADKINS (1931, p. 53, pl. 2, fig. 2) is a good example of the outer whorl of Collignoniceras woollgari (MANTELL). The association thus proves that loc. BEG. 2612 represents the middle part of Turonian. Thus $R$. deverioide seems to be a good indices of the Middle Turonian. Its occurrence in Member II of the Redding area in California is in harmony with this statement.

Romaniceras sp. aff. R. pseudodeverianum (Jімво)

Pl. 27, fig. 1a, b; Text-fig. 46

Compare.-

1894. Acanthoceras pseudodeverianum JiмBo, Pal. Abh., Bd. 6, (N.F. 2), p. 178 [33], pl. 21 [5], fig. 1, 1a, 1b.

1957. Romaniceras pseudodeverianum, Matsumoto, SaIto, and Fukada, Mem. Fac. Sci., Kyushu Univ., ser. D, vol. 6, p. 22, pl. 8, fig. 3; text-fig. 7A-D.

Holotype of Romaniceras pseudodeverianum.-GT. I-106 (Jimbo, 1894, pl. 21 [5], fig. 1, 1a, 1b; Matsumoto, Saito, and Fukada, 1957, pl. 8, fig. 3, text-fig. 7A-C), from Hokkaido.

Material.-The Californian specimen here described is GK. H7050, from loc. TM. 2002 [=LSJU. 3289] (Coll. W. P. Popenoe \& T. Matsumoto).

Measurements.-

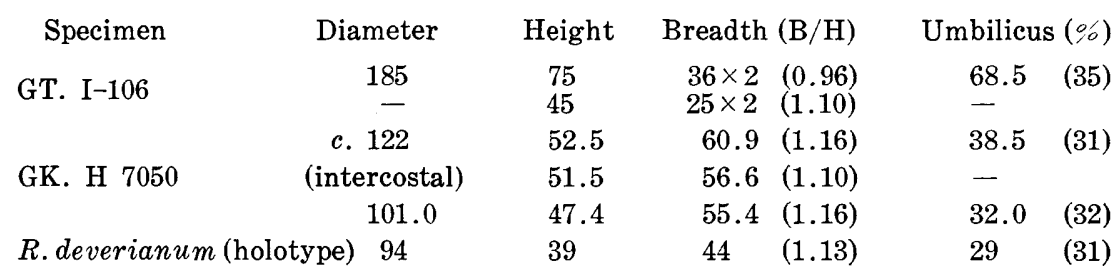

Descriptive remarks.-The Californian specimen before me is very close to, but not quite identical with, Romaniceras pseudodeverianum (JIMBo) (1894, p. 178 [33], pl. 21 [5], fig. 1, 1a, 1b; Matsumoto, Saito, and Fukada, 1957, p. 22, pl. 8, fig. 3; text-fig. 7A-D), from Japan, and also Romaniceras deverianum (D'ORBIGNY) (1840, p. 256, pl. 110; Fritsch and SchloenbaCh, 1872, p. 32, pl. 7, figs. 4, 5; RoMAN and MAZERAN, 1913, p. 25, pl. 3, fig. 2, 2a only ; Collignon, 1939, p. 33, and 37, pl. 8, figs. 2, 3, 3a; pl. 9, fig. 1, 1a), from the Turonian of Europe and Madagascar, in the rounded venter, prominent ribs, and nine rows of tubercles. Its whorl is less compressed than in $R$. pseudodeverianum, being nearly as broad as that of $R$. deverianum. Its ribs are separated by wide inter- 
spaces and its tubercles are not equidistant. In this respect it is closer to $R$. pseudodeverianum, although the ribs are less numerous than those of the Japanese holotype.

There is an abnormal feature in the configuration of the tubercles of this Californian specimen. The distance between the lateral and umbilical tubercles is much shorter than that between the lateral and ventrolateral tubercles on one side of the whorl, as in the Japanese examples of $R$. pseudodeverianum, but the former is slightly longer than the latter on the other side of the whorl; the lateral tubercles are the most prominent on both sides (see Text-fig. 46).

The ribs are rather narrow and sharp on the internal mould of the outer whorl, but may be fairly thick and strong on the shell and on the inner whorl. They cross the venter without decreasing in strength and without noticeable broadening; the ventral tubercles are not clavate. The shorter ribs are less frequent than the longer ones. In all of these characters the specimen under consideration is distinguishable from Romaniceras uchauxiense CoLLIGNoN (1939, p. 38, pl. 10, fig. 1, 1a; Matsumoto, SAito, and FukAda, 1957, p. 24, pl. 9, figs. 1a-c, 2 ; pl. 14, fig. 1a, b; pl. 15, fig. 2) [=Acanthoceras deverianum of RoMAN and MAzeran, 1913, p. 25, pl. 3, fig. 1, 1a only], and is evidently closer to R. pseudodeverianum.

As the Japanese examples are not numerous, the extent of variation of $R$. pseudodeverianum is not exactly known. There is only one specimen from California which is not quite identical with the Japanese holotype and may belong to a new species. For the time being I call this Californian example Romaniceras aff. $R$. pseudodeverianum (JIMBO).

In addition to this Californian representative, I have noticed a few, imperfectly preserved specimens from Texas which can be best compared with $R$. pseudodeverianum. One of them came from loc. BEG. 2612, Chispa summit, west Texas, the same locality as $R$. deverioide (GRossouvrE) $[=R$. loboense AdkINs, 1931]. Another came from "Burnet Road, Travis County, Texas, the condensed zone of the Upper Eagle Ford".

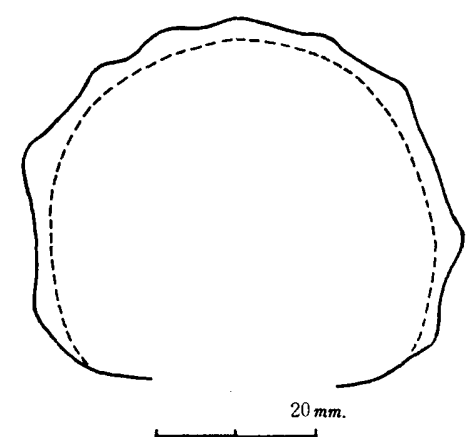

Fig. 46 Romaniceras sp. aff. $R$. pseudodeverianum (JIMBO). Whorl-section of a specimen, GK. H 7050, from loc. TM. 2002 [ $=$ LSJU. 3289], Swede Creek, Redding area, Shasta County. Note the asymmetric configuration of the tubercles. See Pl. 27, fig. 1a, b for other views. 
Occurrence.-The described Californian specimen came from loc. TM. 2002 [=LSJU. 3289], on Swede Creek, Redding area, Shasta County. PopenoE refers all the Cretaceous beds exposed on Swede Creek to his Member IV, which I doubt.

\section{Genus Eucalycoceras SPATH, 1923}

Type-species.-Acanthoceras pentagonum JUKES-BrownE, 1896.

Generic diagnosis.-See Matsumoto, SAIto, and Fukada 1957 (Mem. Fac. Sci., Kyushu Univ., ser. D, vol. 6, no. 1), p. 37; WRIGHT in MOORE [Editor], 1957, p. L413.

Remarks.-As has been previously discussed (MAтsumoto et al, 1957, p. 37), Eucalycoceras may have derived from Calycoceras. According to Wright (a personal information recently given to me) the earliest species of Eucalycoceras in England is E. gothicum (Kossmat) in South Dorset Basement Bed, which is a Calycoceras derivative.

The Californian species described below is not a typical example of Eucalycoceras in that it tends to have lateral tubercles in addition to umbilical, lower and upper ventrolateral, and siphonal tubercles, like some examples from Texas and Mexico.

Mantelliceras phoenixense ANDERSON (1958, p. 244, pl. 13, fig. 2, 2a), from Oregon, is better assigned to Eucalycoceras than to Mantelliceras, although the holotype is too poorly preserved for accurate comparison with the well established species.

\section{Eucalycocerns (?) shastense (REAGAN)}

Pl. 23, fig. 1a-c; Pl. 24, figs. 2a, b, 3a, b; Text-figs. 47-50

1924. Acanthoceras shastense REAGAN, Pan-American Geologist, vol. 41, p. 179, pl. 18, fig. 1.

1958. Acanthoceras shastense, ANDERSON (pro parte), Geol. Soc. Amer., Memoir 71, p. 242 , pl. 20 , figs. 1,2 ; pl. 60 , fig. 5 .

Holotype.-LSJU. 123, from loc. LSJU. 121, Cottonwood Creek, Shasta County. The very point of the type locality is not exactly known.

Material.-In addition to the holotype there are three specimens, which better records of collection than the hulotype: UC. 31502 (Pl. 24, fig. 3a, b; Text-figs. 49, 50) from SOC. K-41 (Coll. KENNEL \& LoBINs) and the other two, GK. H7051 (Pl. 24, fig. 2a, b; Text-fig. 48) and H7052, from loc. TM. 2002 [=LSJU. 3289] (Coll. W. P. POPENoE \& T. MATsumoto)

Measurements.-

$\begin{array}{cccccc}\text { Specimen } & \text { Diameter } & \text { Height } & \text { Breadth (B/H) } & \text { Umbilicus (\%) } \\ \text { LSJU. 123 } & 102.8 & 43.7 & 44.0(1.0) & 34.7 \quad(34) \\ \text { (At the last suture) } & - & 30.0 & 28.0(0.93) & - & \\ \text { "I (1/2 vol. earlier) } & - & 37.3 & 39.9(1.06) & 35.0 & (35) \\ \text { UC. 33730 } & 101.0 & 27.2 & 27.3(1.0) & - & \\ \text { "I (c. } 1 / 2 \text { vol. earlier) } & - & 26.5 & 25.2(0.95) & - \\ \text { GK. H } 7051 & - & 20.2 & 21.0(1.05) & -\end{array}$


Description.-The holotype was described in detail by REAGAN (1924, p. 179, pl. 18, fig. 1) and is remeasured and reillustrated in this paper ( $\mathrm{Pl} .23$, fig. 1a-c; Text-fig. 47). The specimens from the two new localities are not exactly the same in every character. The one from SOC. K-41 has a well preserved body whorl, with the last septate part, and crushed inner whorls. The whorl is nearly as high as broad, rather flattened on the flanks, and moderately rounded on the venter. The ribs are alternately long and short, sometimes with two intercalated shorter ones. They are relatively narrow and elevated, being separated by wide interspaces on the body whorl but not necessarily so on the inner whorls. They are nearly rectiradiate, but some of them are slightly flexuous on the flank and also show a slight forward curve on the venter. The ribs cross the venter with increased intensity, and upon them tubercles are superimposed. The siphonal and upper ventrolateral tubercles are closely set, while the lower ventrolateral ones are somewhat apart from the upper ventrolateral,

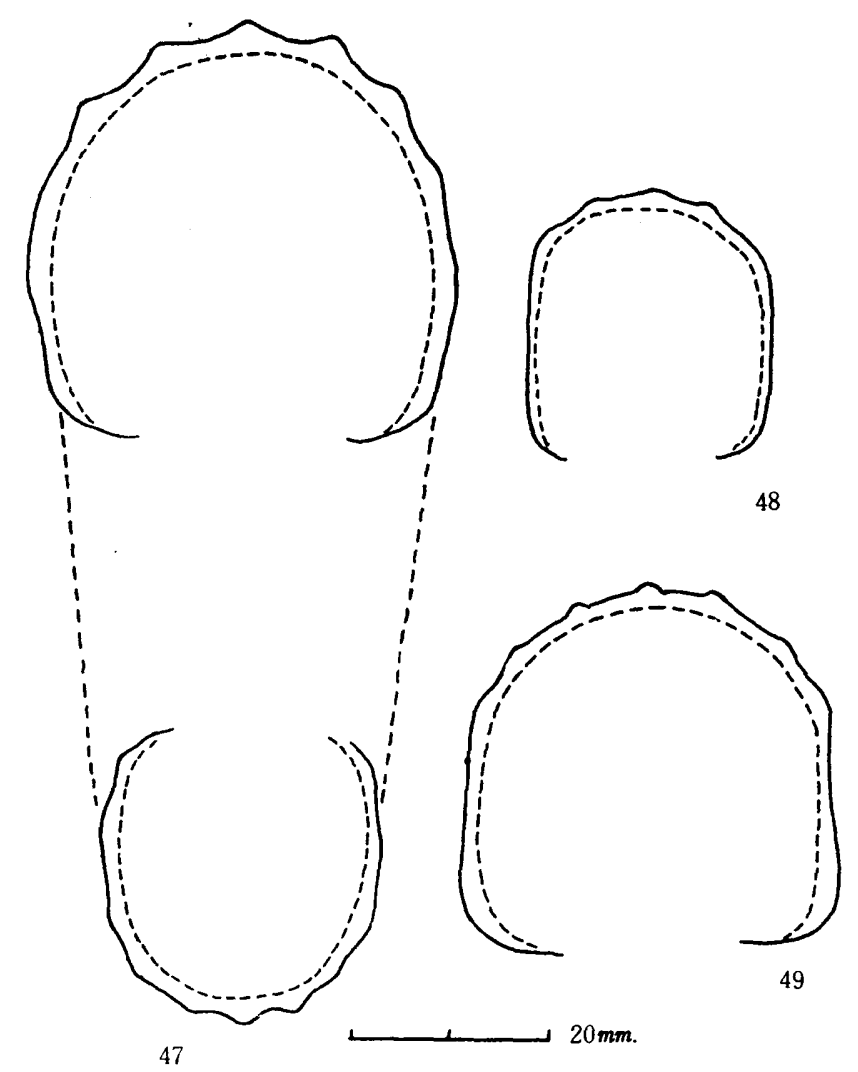

Figs. 47-49. Eucalycoceras (?) shastense REAGAN. Whorl-sections of three specimens.

47. Holotype, LSJU. 123, from the Cottonwood area, Shasta County.

48. GK. H 7051, from loc. TM. 2002 [=LSJU. 3289], Swede Creek, Redding area.

49. UC. 31502, from loc. SOC. K-41, Member II in the Redding area, Shasta County. 
forming a shoulder. The umbilical tubercles on the long ribs are bullate, sometimes showing double elevations. Another elevation on the rib is discernible in the upper lateral part, but, at least on the body whorl, it is not strong enough to be called a tubercle. The suture (Text-fig. 50) has broad saddles and relatively shallow lateral lobes.

One of the two from loc. TM. 2002, GK. H7051, is a half whorl, which is nearly as high as broad, flattened on the flanks, and rounded on the venter. The ribs are prorsiradiate and slightly flexuous on the flanks, also slightly curved forward on crossing the venter, but essentially similar to the ribs on UC. 33730 , although the shorter ribs are less frequent on GK. H7051. The tubercles on both specimens are also essentially similar. The upper lateral tubercles and the double umbilical tubercles are better discernible on the early part of the whorl.

The other, small fragmentary whorl, GK. H7052, from loc. TM. 2002, probably represents the early shell of the same form as GK. H7051. The projection of the ribs on the venter is pronounced and the two lateral tubercles are distinct. There is an impression of an indistinct, constriction-like ornament on the still earlier whorl. The ribs are not so widely spaced as on the outer whorl, although they are still narrower than the interspaces.

Remarks.- The three specimens from the Turonian of the Redding area, here described, certainly represent one and the same species, since the minor differences among them are regarded as variation and also change of characters with growth. The species is most probably assigned to "Acanthoceras shastense REAGAN" (1924, p. 179, pl. 18, fig. 1), because the specimens from the Redding area are identical in diagnostic characters with the holotype of REAGAN's species. One doubtful point is the occurrence of this holotype. REAGAN (1924, p. 180) described that it came "from the Horsetown beds of Early Cretacic age, at Cottonwood Creek, in Shasta County, California." The term "Horsetown beds", used at that date, does not mean any accurate age, although their main part may belong to the Lower Cretaceous. ANIJFRSON did not describe this species in his Lower Cretaceous paper (1938), but reillustrated the holotype in his Upper Cretaceous paper (1958, p. 242, pl. 20, figs. 1, 2; pl. 60, fig. 5). According to him the locality is "North Fork of Cottonwood Creek". Again this means nothing accurate. We have at present enough evidence that Turonian and Cenomanian are represented by certain parts of the section along this creek. Addi-

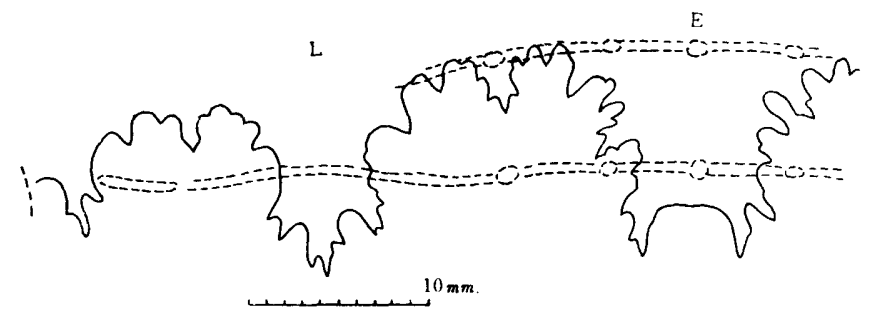

Fig. 50. Eucalycoceras (?) shastense (REAGAN). The last suture of a specimen, UC. 31502 , from loc. SOC. K-41, Member II of the Redding area. See Pl. 24 , fig. $3 a, b$. 
tional examples of the same species from these well defined parts are essential to the obscurity. A specimen from loc. CAS. 33725, labelled as Acanthoceras cf. shastense by ANDERSON (1958, not illustrated) is not useful for this question, because it is not-referable to the present species but is best identified with Calycoceras spinosum (Kossmat).

Now the species under consideration is better assigned to Eucalycoceras than to Acanthoceras, because the whorl has rather flattened flanks and an arched venter, the latter of which is crossed by the elevated ribs and has rows of tubercles, close to one another, superimposed on the ribs. It deviates, however, to a considerable extent from the type-species, E. pentagonum (JUKES-Browne), and other unmistakable examples of Eucalycoceras, in that its ribs are not crowded on the adult body whorl and that it tends to acquire lateral tubercles. In this respect the species might be referred by some to Romaniceras. From loc. TM. 2002 POPENOE and I obtained an example (GK. H7050) of Romaniceras aff. pseudodeverianum (Јімво), from which the present species is clearly distinguished. In both species the ribs become to be predominant over tubercles on the latest part of the adult whorl. But the ventral tubercles persist much better than the lateral tubercles in the present species, while the opposite situation is shown in $R$. pseudodeverianum and other typical examples of Romaniceras.

Multituberculation can occur in several branches of Acanthoceratidae. As I have already mentioned (in MATsumoto, SAlto, \& FUKADA, 1957, p. 27), Calycoceras probably gave rise to Romaniceras, while Acanthoceras produced Yubariceras. Similarly Eucalycnceras might lead to a multituberculate derivative, of which the present species may be an example. It has, however, so obsolete lateral tubercles on the outer whorl and resembles so closely Eucalycoceras in many other respects, that I hesitate to establish a new genus for it. To justify the establishment of a new genus for a multituberculate derivative of Eucalycoceras, we need a systematic set of material. Temporarily I describe the present species as Eucalycoceras (?) shastense (REAGAN), calling attention to the existence of a particular kind of form.

In connection with this problem some of the ammonites from the Turonian of Gulf Coast should be brought into comparison with the Californian species. Eucalycoceras dentonense MoREMAN (1942, p. 205, pl. 33, figs. 4, 5; text-fig. 2k), from the Britton member (Turonian) of Eagle Ford formation of Texas, is closely allied to the present species in its arched venter, proportion of breadth and height of the wohrl, ribbing and configuration of tubercles. The holotype, BEG. 19804, is unfortunately a fragmentary body whorl and MoremaN's drawing of its cross section (1942, text-fig. $2 \mathrm{k}$ ) is not adequate. I illustrate here a better figure (Text-fig. 51). In addition to the holotype, there are several other specimens which are referable to this species. They are in the collection of Texas Christian University and labelled as "Eagle Ford formation", some as "Britton member". All of these, including the holotype, have weak tubercles or tuberclelike elevations at the middle of the tubercles, in addition to the umbilical and ventral tubercles. Therefore, this species is a good example of Eucalycoceras which tends to have nine rows of tubercles. 


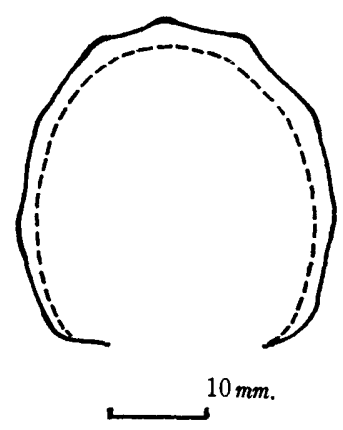

Fig. 51. Eucalycoceras dentonense MoremaN. Whorl-section of the holotype, BEG. 19804, from the Briton member of Eagle Ford shale.

Eucalycoceras indianense MOREMAN (1942, p. 206, pl. 33, figs. 9, 10 ; text-fig. 21 ) is another example of multituberculate Eucalycoceras. The holotype, BEG. 19805 , came from the same locality as that of $E$. dentonense MoREMAN. It has flattened flanks on which ribs are flexuous and have faint elevations at the middle. A specimen in the collection of Texas Christian University, M1102 (G1476), labelled as "Eucalycoceras n. sp.", from the Eagle Ford formation at 3 miles SE. Britton (Coll. MOREMAN), is, in my opinion, another example of this species. It represents the whorl of slightly later growth-stage than the holotype. The ribs become less flexuous and the tubercles are weakened near its anterior end, while its posterior part is indistinguishable from the holotype. This species is closer to Eucalycoceras in that its lateral tubercle-like elevations are very faint.

On looking at the plaster cast of the holotype of Romaniceras indiduraense JoNES (1938, p. 119, pl. 7, figs. 2-4), which was presented to Kyushu University by the courtesy of Professor L. B. KELLUM of Michigan University and Dr. W. A. Cobban of U. S. Geological Survey, Denver, I have recognized its remarkable similarity of Eucalycoceras pentagonum (JUKES-BROWNE) (1896, p. 156, pl. 5, fig. 1, 1a), but for its weak, bullate, lateral tubercles. JoNES' species occurs in the Indiana formation (Turonian) of Coahuila, northeastern part of Mexico, along with other species of Romaniceras. It differs from the Californian species in its more compressed whorl, denser and weaker ribs.

Occurrence.-Loc. SOC. K-41, Millville Quadrangle, northeast of Redding, Shasta County, Member II of PopenOE; loc. TM. 2002 [=LSJU. 3289], Swede Creek, Millville Quad., northeast of Redding, Shasta Co., the locality was referred by POPENOE to Member III-IV transition, but is questionable. Uncertainty about the type locality in the Cottonwood Creek area has been mentioned above.

\section{Genus Kanabiceras ReEside and WeYmouth, 1931}

Type-species. - Acanthoceras (?) kanabense Stanton, 1894 [1893], by original designation, which is the synonymy of Scaphites (?) septemseriatum Cragin, 1893.

Remarks.-The genus is at present represented by a single species. For 
the generic diagnosis and relationship with Euomphaloceras SPATH, 1923 see the description of the species.

Kanabiceras is an index of a limited part near the boundary of Upper Cenomanian and Lower Turonian. It occurs not only in the Western Interior and Gulf Coast of North America but also in western Europe, Japan, and California.

\section{Kanabiceras septemseriatum (CRAGIN) \\ PI. 24, fig. 1a-c; Text-figs. 52, 53}

1893. Scaphites (?) septem-seriatus Cragin, Texas Geol. Surv., 4th Ann. Report, 1892, p. 240.

1894. Acanthoceras (?) kanabense Stanton, U. S. Geol. Surv. Bull. 106, 1893, p. 181, pl. 36, figs. 6-8.

1927. Acanthoceras kanabense, Moreman, Jour. Paleont., vol. 1, no. 1, p.95, pl. 13, fig. 5 .

1928. Scaphites septem-seriatus, Adkins, Univ. Texas Bull., 2838, p. 259.

1931. Kanabiceras kanabense, Reeside \& Weymouth, U. S. Nat. Mus. Proc., vol. 78 , art. 17, p. 1, pl. 11 .

1931. Neocardioceras septem-seriatum, AdKINS, Univ. Texas Bull., 3101, p. 60, 72

1942. Neocardioceras septemseriatum, MoReman, Jour. Paleont., vol.16, p. 213, pl. 33, figs. 11, 12 ; text-fig. 2 f.

1957. Kanabiceras septemseriatum, WRIGHT, in MOORE [Ed.], Treatise on Invertebrate Paleontology, p. L414, fig. 534, 5a, b.

1958. Lyelliceras stanislausense ANDERSON, Geol. Soc. Amer., Memoir 71, p. 247, pl. 8, fig. 5, 5a.

Types.-Holotype, by monotypy, is CragiN's original specimen, in the collection of BEG., University of Texas, which came from "Dallas County, Keenan's Crossing of Trinity River, Texas", Eagle Ford formation (ADKINS, 1928, p. 259).

Stanton's syntypes of Acanthoceras (?) kanabense, which came from "Upper Kanab, Utah", are in U. S. National Museum, on which Kanabiceras was established by REESIDE and WEYMOUTH (1931, p. 1). I agree with WRIGHT (1957) in regarding Kanabiceras kanabense (STANToN) as a synonym of Kanabiceras septemseriatum (CRAGIN).

Material.-The Californian examples which I refer to the present species are five. . One is the holotype of "Lyelliceras stanislauensis ANDERSON" (1958, p. 247, pl. 8, fig. 5, 5a) from loc. CAS. 31131. Two others are from loc. CAS. 33719; and the other two, one of which, UC. 31477, is illustrated here (Pl. 24, fig. 1a-c; Text-figs. 52, 53), are from loc. SOC. K-209 (Coll. M. V. KIRK).

In addition to the originals of CRAGIN (1893) and MOREMAN (1927, 1942), which are in the University of Texas, and those of STANToN in USNM., I have seen many specimens from the Britton clay member of Eagle Ford formation in the collections of Southern Methodist University (Coll. D. L. CLARK and others) (Dallas), Texas Christian University (Fort Worth), and C. W. WRIGHT. All of these are helpful for better understanding of the present species. 


\section{Measurements.-}

\begin{tabular}{|c|c|c|c|c|}
\hline Specimen & Diameter & Height & Breadth $(\mathrm{B} / \mathrm{H})$ & Umbilicus $(\%)$ \\
\hline Holotype (costal) & - & c. 26.5 & $19.9 \times 2(1.50)$ & - \\
\hline USNM. 22937 ('kanabense') & 49.0 & 18.0 & $26.0(1.44)$ & - \\
\hline UC. 31477 & 65.0 & 25.5 & $34.0(1.33)$ & 22.3 \\
\hline "I (costal, exclud. spine) & e) - & 26.0 & $37.8(1.45)$ & 一 \\
\hline "I (septate part) & 46.0 & 17.4 & $24.2(1.39)$ & $15.4 \quad(3$ \\
\hline$\prime \prime(" \prime$, , costal $)$ & - & 18.3 & $27.0(1.47)$ & - \\
\hline $\begin{array}{l}\text { Another from SOC. K-290 } \\
\text { (deformed) }\end{array}$ & 43.5 & 18.0 & $24.5(1.36)$ & 16.5 \\
\hline
\end{tabular}

Diagnosis.-The shell is fairly small, relatively evolute, and fairly widely to moderately umbilicate. The whorl is depressed and coronate in section, having a deep and vertical umbilical wall, abruptly rounded umbilical shoulder, inflated flanks, and broadly arched venter.

The ribs consist of major and minor ones in rather irregular alternation. They show typically a gentle forward projection on the venter. The ventral tubercles in three rows are small but persistent and approximated, the siphonal ones tending to form a keel, and the paired ones being typically arranged obliquely. The tubercles at the ventrolateral shoulder are very prominent on the major ribs, forming laterally projected spines. The spines on the inner whorl stretch out along the umbilical wall of the outer whorl. The tubercles at or slightly above the umbilical shoulder are fairly prominent on the major ribs. The ventrolateral and umbilical tubercles on the minor ribs are weak, bullate, sometimes oblique forward, and in some case almost obsolete.

Some of the interspaces of the ribs are relatively deep and can be called constrictions. Near the apertural margin of the adult whorl, a well marked

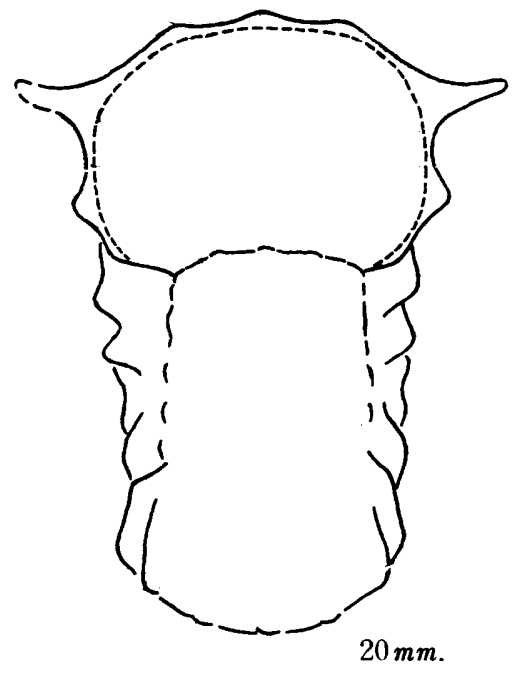

Fig. 52. Kanabiceras septemseriatum (CRAGIN). Diagrammatic outline of the front view. A Californian example, UC. 31477, from loc. SOC. K-209, Roaring River, Ono Quadrangle, Shasta County. 
constriction crosses the venter with a forward curve.

The suture is relatively simple, with broadly opened lateral lobe. The saddle is broad and dome-like in general outline.

Variation.-Many specimens from the Britton clay member of Eagle Ford formation (Texas) show a considerable extent of variation. Some of them have coarser, less distinctly curved, and more distant ribs than the holotype. The ventral tubercles on these specimens are nodose, the siphonal ones not forming the keel, and the paired ones not being arranged obliquely.

One of the Californian examples is comparable with this kind of variety, while another, better preserved specimen from the same locality (SOC. K-209) is close to the typical examples of the species. The specimen that was called the holotype of "Lyelliceras stanislausense ANDERSON" (1958, p. 247, pl. 8, fig. 5, $5 a)$ is also indistinguishable from the inner whorl of the typical examples from the Britton member. Moreman's specimens (1927, p. 95, pl. 13, fig. 5; 1942, p. 213, pl. 33, figs. 11, 12) belong also to the typical form.

Remarks.-This species is so diagnostic that it is almost unmistakable. David JoNES (personal communication, April, 1957) independently considered that ANDERSON's specimen should be referred to Kanabiceras.

Although the species has frequently been assigned to Neocardioceras (ADKINS, 1931; MOREMAN, 1942) Kanabiceras is well distinguishable from Neocardioceras as WRIGHT (1957, p. L414) has recently clearly shown.

The difficulty is how to distinguish Kanabiceras from Euomphaloceras. Since K. kanabense (CRAGIN) itself shows such a variation as described above, the criteria of Kanabiceras that the "paired tubercles on the venter are oblique and that the siphonal tubercles form a nodose keel" are not always effective. Even in the atypical variety, however, the inner whorl shows or tends to show these features. Therefore, we can still follow Wright's definition (1957, p. L414), with slight modification. Another criterion is that the ventral three rows of tubercles persists up to the adult whorl in $K$. kanabense, while in the adult whorl of Euomphaloceras they fade out, minor ribs are also lost, and the ventrolateral tubercles are strengthened. Size may be another distinction. All

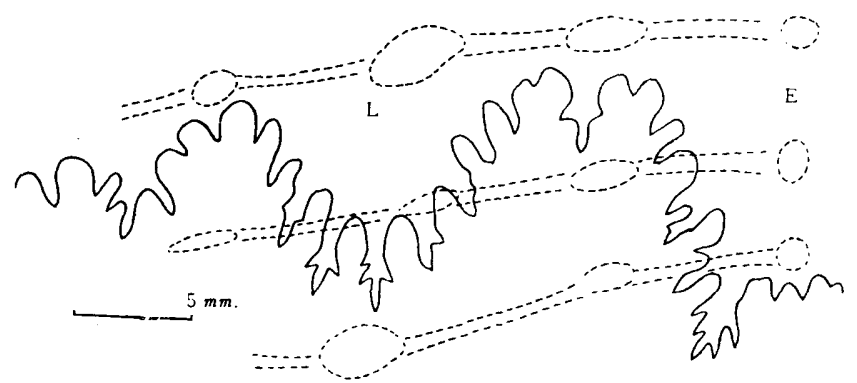

Fig. 53. Kanabiceras septemseriatum (CRAGIN). External suture, at whorlheight $=17.4 \mathrm{~mm}$., breadth $=24.2 \mathrm{~mm}$, of a Californian example, UC. 31477 , from loc. SOC. K-209, Roaring River, Shasta County. Dotted lines indicate the ribs and the tubercles. 
the available specimens, including the probable adult examples, of $K$. kanabense (CRAGIN) are much smaller than the adult shells of Euomphaloceras.

Anyhow Kanabiceras (of Lower Turonian) is so intimately related to Euomphaloceras (of Upper Cenomanian), that the former is doubtlessly a descendant of the latter. In our present knowledge, however, we cannot tell exactly what species of Euomphaloceras is the direct ancestor of K. kanabense (CRAGIN). I suggest, as one of the possibilities, that Euomphaloceras lonsdalei (ADKINS) (1928, p. 244, pl. 26, fig. 5; pl. 27, fig. 3) from the Eagle Ford flag member of Texas could be the origin, because its earlier whorl is closely similar to the relatively rectiradiate variety of $K$. kanabense (CRAGIN).

Occurrence.—Loc. SOC. K-209, Roaring River, Ono Quadrangle, associated with Plesiovascoceras cf. californicum (ANDERSON), Lower Turonian on northwest side of the Sacramento Valley; Locs. CAS. 31131, upper branch of Garzas Creek; CAS. 33719, upper branch, southwest of Garzas Creek, associated with Sciponoceras kossmati (NoWAK) and Inoceramus cf. labiatus ScHLotheIM, Lower Turonian. In Texas and in the Western Interior the species occurs in the Lower Turonian. In Japan I have recently found examples at the top of the middle member of the Mikasa formation in the Ikushumbets Valley, Hokkaido, along with Sciponoceras kossmati (NowAK) and Inoceramus cf. labiatus SchLOTHEIM.

Family Vascoceratidae Douvillé, 1911

Genus Plesiovascoceras Spath, 1926

Type-species.-Ammonites catinus MANTELL, 1822 (from the Lower Turonian of England), by original designation.

Remarks.-A diagnosis of this genus and a comparison with Vascoceras Choffat, 1898 and Fagesia PervingIere, 1907 have recently been given by BARBER (1957, p. 13-15 and p. 62).

\section{Plesiovascoceras californicum (ANDERSON)}

Pl. 36, fig. 1a-c; Text-fig. 54a, b

1931. Fagesia californica Anderson, Jour. Paleont., vol. 5, p. 123, pl. 15, fig. 1; pl. 16, figs. 1, 2, pl. 17, fig. 1; text-fig. 1A.

1931. Fagesia shastensis ANDERSon, Jour. Paleont., vol. 5, p. 124, pl.16, fig. 3; text-fig.1B.

1958. Fagesia californica ANDERSon, Geol. Soc. Amer., Memoir 71, p. 248, pl. 39, figs. 1, 2 .

Holotype.-CAS. 5496, by original designation, which was found "in Hayes Gulch, near Gas Point", Ono Quadrangle, Shasta County (ANDERson, 1931, p. 124).

Material.--In addition to the holotype and paratypes of "Fagesia" californica ANDERSON and the holotype (CAS. 4690) of Fagesia shastensis ANDERSON, which, in my opinion, is identical with " $F$." californica, there are two specimens 
of M. V. KIRK's collection: one, UC. 33730 (PI. 36, fig. 1a-c; Text-fig. 54a, b), from loc. SOC. K-209, and the other, from loc. SOC. K-69. A poorly preserved external mould of a specimen, from loc. LSJU. 3339 (Coll. W. N. BARBAT), and another small, probably immature, specimen, from loc. LSJU. 2956 (Coll. S. W. MULLER) may be comparable with the present species.

Measurements.-

\begin{tabular}{|c|c|c|c|c|c|c|}
\hline Specimen & Diameter & Height & Breadt & $(\mathrm{B} / \mathrm{H})$ & \multicolumn{2}{|c|}{ Umbilicus $(\%)$} \\
\hline CAS. $5496\{1 / 2$ vol. early & $\begin{array}{l}250 \\
200\end{array}$ & $\begin{array}{l}72 \\
55\end{array}$ & 95 & (1.73) & $\begin{array}{r}122 \\
92\end{array}$ & $\begin{array}{l}(49) \\
(46)\end{array}$ \\
\hline CAS. 4690 & 137 & 42 & - & & 62 & (45) \\
\hline UC. $33730\{1 / 4$ vol. early & 86 & $24+$ & $\begin{array}{l}50+ \\
21 \times 2\end{array}$ & $\begin{array}{l}(2+) \\
(2.0)\end{array}$ & 43.8 & $(5$ \\
\hline One from SOC. K-69 & c. 100 & 31.5 & 60 & $(1.9)$ & 40.8 & \\
\hline
\end{tabular}

Diagnosis.-The shell is large, widely umbilicate and relatively evolute. The whorl is much depressed, reniform in cross section, with a broadly rounded venter and inflated flanks. The umbilical or lower lateral tubercles are distant, broadly rounded, and may be weakened on some specimens. The broad ribs which run from the tubercles are weakened on the venter and on the outer whorl. The suture is moderately incised; the lobes are fairly deep; the saddle on the umbilical tubercle is relatively broad.

Remarks.-The shell is less evolute and less widely umbilicate in the earlier growth-stages than in the later. ANDERSON described Fagesia shastensis ANDERsON as having a wider umbilicus than $F$. californica ANDERSON, but there is no significant distinction between the holotypes of the two species in this respect, as the measurements clearly indicate. The ornament varies in strength by growth-stages and also by individual. Again no remarkable difference can be recognized between the type specimens of ANDERson's two species. Fagesia shastensis ANDERSON (1931, p. 124, pl. 16, fig. 3; text-fig. 1B) is thus proved to be specifically identical with Fagesia californica ANDERSON (1931, p. 123, pl. 15, fig. 1 ; pl. 16, fig. 1 ; text-fig. $1 \mathrm{~A}$ ).

ANDERSON (1958), in his recent paper, kept this species in Fagesia. But from all the observable characters it is better referred to Plesiovascoceras, as BARBER (1957, p. 15) already pointed out on the occasion of describing the African species of the Vascoceratidae.
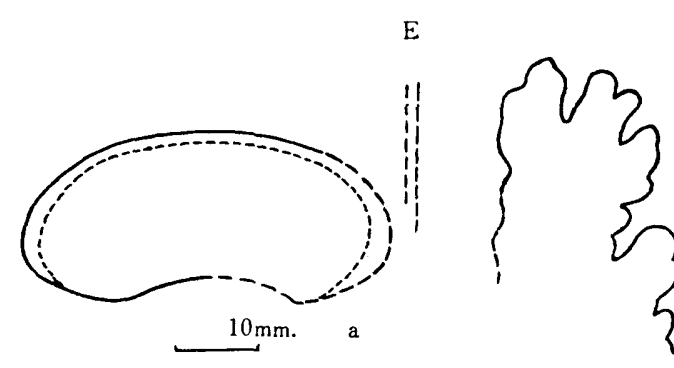

L $\mathrm{U}_{2}$

Fig. 54. Plesiovascoceras californicum (ANDERSON). Whorl-section (a) and external suture (b) of an example, UC. 33730, from loc. SOC. K-209, Roaring River, Ono Quadrangle, Shasta County. See Pl. 36, fig. 1a-c. 
In a small, probably immature, specimen, from loc. LSJU. 2956, the ribs spring normally in pairs from the umbilical tubercles and are interrupted (or much weakened) at mid-venter, with slight thickening near the ventral ends of the ribs. The same feature are to be expected on the young whorl of ANDERson's holotype and other larger specimens, but without destroying the outer whorl the ventral part of the inner whorl cannot be inspected.

In the above mentioned feature and other points the Californian species has some affinity with Plesiovascoceras thomi (REESIDE) (1923, p. 29, pl. 11, figs. 1,2 ; pl. 12 , figs. 1,2 ; pl. 13 , figs. 1,2 ; pl. 14, figs. 1, 2 ; pl. 15, figs. 1-7; pl. 16, figs. 1-6), from the Lower Turonian of Montana, but the former has relatively broader whorls and weaker ribs than the latter. Plesiovascoceras moultoni (RFesIDE) (1923, p. 30, pl. 17, figs. 1, 2; pl. 18, figs. 1, 2) and $P$. stantoni (REESIDE) (1923, p. 30, pl. 19, figs. 1, 2; pl. 20, figs. 1-3; pl. 21, figs. 1-3), from the Lower Turonian of Montana, have whorls nearly as depressed as those of $P$. californicum, but their umbilical shoulders are subangular as compared with the rounded ones of the Californian species.

Occurrence.-The type locality of $P$. californicum is, according to ANDERSON (1931, p. 124), somewhere in "Hayes Gulch, near Gas Point (Ono Quadrangle), Shasta County". It may not be far from loc. CAS. 34405, where Sciponoceras baculoide (MANTELL) (see description in Part I, p. 105) was obtained. The stratigraphic relationship between the beds of Sciponoceras and Plesiovascoceras should be examined in the field. The type locality of "Fagesia shastensis ANDERsoN" is recorded as "the Middle Fork of the Cottonwood Creek, some 6 miles southwest of Gas Point, midway between the basal conglomerates of the Chico group and the Foster ranch house (ANDERSON 1931, p. 125). Its horizon is, according to ANDERSON, above the beds with Calycoceras newboldi and below the beds with Inoceramus labiatus.

One of KIRK's collections, here described, is loc. SOC. K-209, Roaring River, Ono Quadrangle, Shasta County. The species is associated with Kanabiceras septemseriatum (CRAGIN). The other is loc. SOC. K-69, Peterson Ranch, Lodoga Quadrangle, Colusa County, west side of the Sacramento Valley. It is on the west flank of Logan Ridge, apparently below the Venado sandstone, but many Upper Albian ammonites occur in the neighbouring area. Therefore there must be some complexity in the geologic structure or sedimentary feature of the Cretaceous strata of this area (see Part III).

Comparable specimens are from loc. LSJU. 3339 and loc. LSJU. 2956, west of Coalinga. Their beds are probably assigned to "Upper Waltham shale".

Family Collignoniceratidae WrIGHT and WRIGHT, 1951

Subfamily Collignoniceratinae WrIGHT and WRIGHT, 1951 Genus Collignoniceras BREISTROFFER, 1947

Type-species.-Ammonites woollgari MANTELL, 1822.

Synonym.-Prionotropis MEEK, 1876 (non FIEBER, 1853). 
Remarks.-The generic diagnosis recently written by WRIGHT (in MoorE [Editor], 1957, p. L426) is concise but adequate. The genus is widespread in the Turonian.

\section{Collignoniceras woollgari (MANTELL)}

Text-figs. 55-57

1822. Ammonites woollgari MANTELl, The fossils of the South Downs, p. 197, pl. 21, fig. 16; pl. 22, fig. 7 .

1855. Ammonites woollgari, ShaRPe, Palaeontogr. Soc., 1854, p.27, pl.11, figs. $1,2$.

1876. Prionocyclus (Prionotropis) woolgari, MEEk, U. S. Geol. Surv. Territories, vol. 9 , p. 455 , pl. 7 , fig. 1a-h; pl. 6 , fig. 2 .

? 1902. Schloenbachia bakeri Anderson, Proc. Calif. Acad. Sci., 3rd ser., vol. 2, p. 121, pl. 2, figs. 26-33.

? 1925. Prionotropis teshioensis YABE and ShImizu, Sci. Rep. Tohoku Imp. Univ., ser. 2, vol. 7, p. 134 [10], pl. 21 [2], fig. 10; pl. 33 [4], figs. 6-10.

1946. Prionotropis woollgari, HAAS, Bull. Amer. Mus. Nat. Hist., vol. 86, p. 150, pl. 11, pl. 12 ; pl. 13 ; figs. $1-19$; pl. 14, figs. $1-16$; pl. 15, figs. $1-10 ;$ pl. 16, figs. 1-33 (non pls. 17, 18) ; text-figs. 1-14, 23-78, 80-83.

1951. Collignoniceras woollgari, WRIGHT and Wright, Palaeontogr. Soc., 1950, p. 30 .

1956. Collignoniceras woollgari, CobBan, Rohrer, and Erdmann, Jour. Paleont., vol. 30 , p. 1269 , text-fig. 1B-H.

1958. Collignoniceras woolgari, MAtsumoto and MiLler, Jour. Paleont., vol. 32, p. 353 , pl. 44 , figs. $1-6 ;$ pl. 45 , fig. 1 .

1958. Calycoceras (Metacalycoceras) auspicium ANDERSON (pro parte), Geol. Soc. Amer., Memoir 71, p. 243, pl. 20, fig. 9 (non fig. 8).

1958. Prionotropis bakeri, ANDERSON, Geol. Soc. Amer., Memoir 71, p. 261, p1. 38, figs. 2-5.

Type.-The original from MANTELL's collection, BM. 5682, figured by SHARPE (1855, pl. 11, fig. 1a, b) has been designated by WRIGHT and WRIGHT (1951, p. 35) as the lectotype of Collignoniceras woollgari (MANTELL).

Material.-I have studied, in addition to the lectotype, the specimens which were dealt with by the subsequent authors as listed in the above synonymy.

The specimens from California and Oregon are not always well preserved, some being comparable with the present species from synthetic judgement based on several fragments. The examples are mentioned below.

Diagnosis.-The full-grown shell is fairly large. The whorl is moderately evolute, somewhat higher than broad or nearly as high as broad in intercostal section. The costal section is subquadrate and on the outer whorl strongly horned at the ventrolateral edges. The ventral keel is continuous and serrated, each serration normally corresponding to one rib. The ribs are simple, of equal length, normally without intercalation of secondary ribs, prorsiradiate, remarkably projected on the venter, and becoming sooner or later distant and coarse on the outer whorls. Each rib has an umbilical tubercle, a conical inner ventrolateral tubercle, and a clavate outer ventrolateral tubercle. On the whorl of middle growth-stage the two ventrolateral tubercles have a common base and 
finally on the outer whorl the weakened outer ventrolateral tubercle is united with the strongly horned inner ventrolateral one, which may absorb the umbilical one too. The clavate siphonal tubercles form serrations on a continuous keel. The suture consists of moderately broad external lobe, massive, subquadrate, bifid, external saddles, moderately deep and narrow lateral lobes, smaller umbilical lobe, and a deep and narrow internal lobe. Minor indentations are relatively shallow.

Remarks.-The wide variation of this species has been illustrated in detail by HAAS (1946) and confirmed by other authors (COBBAN, RoHRER, and ERDMANN, 1956; MATsumoto and MilleR, 1958). I suggest, however, that some, if not all, of the specimens described as "Prionotropis woollgari var. praecox and alata" (HAAs, 1946) should be included in C. hyatti (STANTON).

Some of the American authors, e.g. Moreman, 1942 and HAAs, 1946, doubted the specific identity of the American and British forms. Through the study of the specimens from both regions, I am convinced that they are of identical species. As I could not trace the repository of Ammonites graysonensis SHUMARD (1857, p. 593; WHITE, 1883, p. 39, pl. 18, fig. 9) I have no comments on the Gulf Coast form, although there are, in the subsequent collections, several specimens which are well comparable with Collignoniceras woollgari (see p. 92).

"Prionotropis woollgari MANTELl var. mexicana BöSE" (1927, p. 262, pl. 11, figs. 11, 12), the holotype of which is in the University of California, shows on its whorl of middle growth-stage ribs less projected on the venter, less continuous keel, and some intercalatory secondary ribs. Therefore it should be separated from Colligroniceras woollgari and should better be called Collignoniceras (Selwynoceras) mexicanum (BösE), although the fairly projected ribs on the latest part suggest an intermediate stage between Selwynoceras and Collignoniceras (s.s.). BösE's specimen was obtained from a limestone "immediately above the dark beds with abundant Inoceranius labiatus" (BöSE 1927, p. 170). He mentioned the existence of the group of $C$. (Selwynoceras) schlueterianum (LAUBE and BRUdER) in the labiatus bed.

The specimens from Oregon at my disposal are mostly small, probably

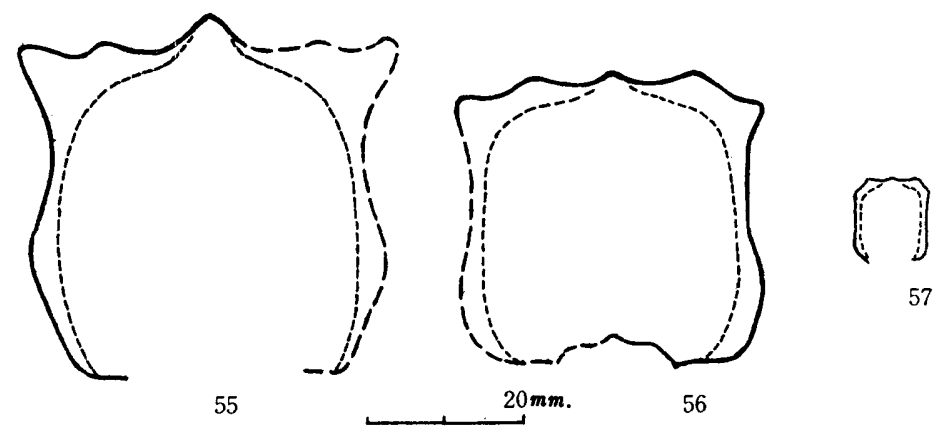

Figs. 55-57. Collignoniceras woollgari (MANTELL). Whorl-sections (partly restored) of three examples from loc. UC. A-170, FiTCH ranch, Oregon. 
immature, shells. The "holotype" of Schloenbachia bakeri ANDERson (1902, pl. 2, fig. 26; 1958, pl. 38, figs. 3) from Forty-nine Mine, near Phoenix, was regarded by ANDERSON (1902) as being adult, but is only $30 \mathrm{~mm}$. in diameter. ANDERSON's other specimens (1958, pl. 38, figs. 3, 4, 5), from FiTCH ranch [= SMITH ranch], are also small. These specimens are indistinguishable from the inner whorls of Collignoniceras woollgari. There are in the collections of UC., from the same FiTcH ranch, loc. UC. A-170, several specimens at different growth-stages. Three of them, although fragmentary, represent the relatively outer whorls (see Text-figs. 55, 56) showing distant, coarse ribs, larger ventrolateral tubercles, projection of the ribs on the venter and coarsely serrated keel. Thus the existence of $C$. woollgari in Oregon is proved by these specimens, and Schloenbachia bakeri ANDERSON very probably falls in the synonym of $C$. voollgari (MANTELL).

Comparable specimens are met with in California. Again they are mostly crushed and the large outer whorls are rather rare, while small, probably immature specimens occur in abundance. They are from the localities as listed below.

Like the Western Interior specimens, those from Oregon and California show wide variation. Besides the density and coarseness of the ribs, there is one more points which should not be overlooked. The serrations of the keel normally correspond in number to the ribbing, but in some cases on the outer whorl an additional weak serration is discernible. Also some of the ribs are slightly weaker than others, although they are of nearly equal length. This point apparently foreshadows the characters of Collignoniceras hyatti (STANTON) (1893, p. 176, pl. 42, figs. 5-8), of the succeeding geological age. The same feature can be found, although very indistinctly, even in the British lectotype and also MEEx's illustrated types of $C$. woollgari. I myself, together with Miller, (1958, p. 354) mentioned the same point in connection with the Kansas specimens. The relationship of the two species should be carefully studied both paleontologically and stratigraphically; the status of HAAS (1946) varieties "praecox" and "alata" could then be settled. In California and Oregon I have not yet seen any examples which are referable with certainty to C. hyatti.

The Japanese specimens, which were described under Prionotropis teshioensis YABE and Shimizu (1925, p. 134 [10], pl. 31 [2], fig. 10; pl. 33 [4], figs. 6-10) can be regarded as being still within the variability of $C$. woollgari. But the Japanese form is peculiar in that the ribs on the very young whorl are apparently alternately long and short, although the difference in length is slight and on the main part of later whorls the ribs are simple and nearly of equal length.

A word must be added about the spelling of the specific name. I understood that the long continued misspelling by many American authors was corrected by MULLER ans ScheNCK (1943, p. 272, fig. 6) and also by HAAS (1946, p. 150). But there seems to be still misunderstanding, because the correct writing of woollgari by MATsUmoto and MILLER (1958) in their original manuscript was erroneously changed to woolgari in printing of the Journal of Paleontology with- 
out consulting the authors.

Occurrence.--"Forty-nine Mine, near Phoenix" and "FiтcH ranch [=SMITH ranch], 2 miles southwest of Phoenix", Oregon. The precise stratigraphic records are not available for these two localitics. In California the following localities are known:

Loc. CAS. 465, near Horsetown, Shasta County (Coll. F. M. ANDERson) [The specimen from this locality was described as a paratype of Calycoceras (Metacalycoceras) auspicium ANDERSON (1958, p. 243, pl. 20, fig. 9), but it is nothing but an immature example of $C$. woollgari.]

Loc. CAS. 1690, North Fork of Cottonwood Creek, in greenish grey shale, 2 miles below the mouth of Hulen Creek, Shasta County (Coll. F. M. ANDERSON)

Locs. CAS. 33730 and CAS. 34408, Middle Fork of Cottonwood Creek, near HICK MAN ranch, Shasta-Tehama Counties

Locs. SOC. K-201, K-202, K-203, Dry Creek, Tehama County (Coll. M. V. KIRK )

Loc. UC. B-769, Puerto Creek, Stanislaus Co. (Coll. Marshall MADDock) [a poorly preserved specimen]

Loc. CAS. 28175, CAS. 29598, and UC. A-2957, Quinto Creek, in a unit of greenish grey sandy shale, Merced County (Coll. TAFF and Cross; Allan BENNISON)

Thus the species seems to be widespread at a certain horizon in California and Oregon. It occurs in western Europe and the Western Interior of North America in the middle part of Turonian (or lower part of Upper Turonian), forming a definite zone together with Inoceramus cuvieri SowERBY.

Genus Subprionocyclus SнIмizu, 1932

Type-species.-Prionotropis hitchinensis BILlinghuRst, 1927.

Synonym.--Oregoniceras ANDERSON, 1958.

Generic diagnosis.-The shell is small or of moderate size. The whorl is considerably involute to moderately evolute and more or less compressed, with a keeled venter.

The ribs are fine to moderately coarse, normally springing in pairs from the umbilical bullae or alternately long and short, typically flexuous and prorsiradiate on the flank and projected on the venter. The ribs have umbilical, two ventrolateral, and siphonal tubercles, the last of which corresponds to the serration on the keel. The lower (or inner) ventrolateral tubercles are weakened on the adult whorl and sometimes also on the very young whorl; the upper (or outer) ventrolateral ones are distinct throughout life and usually clavate.

The suture is similar to that of Collignoniceras.

Remarks.-ShimizU's genus had been almost neglected until WRIGHT and MATSUmoto (1954, p. 129) gave an emended diagnosis. It has now become evident that Subprionocyclus includes several important species and that it is 
widespread in the Upper Turonian.

Subprionocyclus is closely allied to and is probably derived from Collignoniceras of Lower to Middle Turonian. S. branneri (ANDERSON) described below may represent an intermediate stage.

As a criterion for distinguishing Subprionocyclus from Collignoniceras SHimizu (1932) laid too much stress on trivial characters of the internal suture. The distinction is rather in ornament. The ribs are typically paired or alternately long and short and often sigmoidal in Subprionocyclus, but simple, equally long, and nearly straightly oblique in Collignoniceras (s.s.). In Subprionocyclus the upper ventrolateral tubercles appear earlier and are more persistent than the lower ventrolateral tubercles; the latter tend to be weakened or nearly obsolete on the adult whorl. In Collignoniceras (and also in Prionocyclus) the ventrolateral tubercles are doubled at first but later the upper ones are weakened while the lower ones are strengthened and finally become horns; the former being superimposed on or even absorbed by the latter on the outer whorl.

Oregoniceras ANDERSON, 1958 is very probably a synonym of Subprionocyclus SHIMIZU, 1932. Its type-species, Schloenhachia oregonensis ANDERson (1902, p. 122 , pl. 2, figs. $48-57$; pl. 6 , fig. 144 ; pl. 7 , figs. 145 , 150), is probably a young Subprionocyclus, although it might be a Reesidites WRIGHT and MATSUmoto, 1954. Other numerous species which ANDERSON (1958) referred to Oregoniceras can be sorted into a smaller number of species of Subprionocyclus.

As Wright (1957 in Moore [Editor]) and I (MAtsumoto, 1955a) have discussed, Subprionocyclus is important in that it probably gave rise to Reesidites, Barroisiceras, Protexanites, and Paratexanites.

\section{Subprionocyclus branneri (ANDERSON) \\ Text-figs. 58,59}

? 1896. Prionotropis neptuni, Woods (non GeINITZ), pro parte, Quart. Jour. Geol. Soc. London, vol. 52, p. 77, pl. 3, fig. 3 only.

1902. Prionotropis branneri AndERson, Proc. Calif. Acad. Sci., 3rd ser. vol. 2, no. 1, p. 125, pl. 1, figs. 11-16.

? 1927. Prionotropis cristatum Billinghurst, Geol. Mag., vol.64, p. 515, pl. 16, fig. 3a-c.

? 1951. Collignoniceras cristatum, Wright and Wright, Palaeontogr. Soc., 1950, p. 30 .

? 1954. Subprionocyclus cristatus, Wright and Matsumoto, Mem. Fac. Sci., Kyushu Univ., ser. D, vol. 4, no. 2, p. 129.

1958. Prionotropis branneri, ANDERson, Geol. Soc. Amer., Memoir 71, p. 261, pl. 34, figs. 1, 2, 3, 3a.

1958. Prionotropis casperi Anderson, Geol. Soc. Amer., Memoir 71, p. 262, pl. 34, fig. 6 ; pl. 39, figs. 3,4 .

Types.-ANDERSON (1902) established this species on several syntypes, mentioning that "the types are in the collections of the California Academy of Sciences.". One of them, CAS. 48 (ANDERson 1902, pl. 1, fig. 11) (Text-fig. 58 in this paper), was not destroyed by the fire of 1906, being still preserved in 
the same institution. ANDERson (1958 [not 1902]) called it the holotype but it is not; his intention is met if it is designated lectotype, and I hereby so designate it. It came from loc. CAS. 445A, FITCH ranch [=SMITH ranch], near Phoenix, Oregon.

Material.-No undoubted Californian specimens are known, although its occurrence is to be expected. In addition to the lectotype, there are several examples from southwest Oregon:

UC. 12105 (Text-fig. 59), from Fitch ranch, west of Phoenix, an unillustrated hypotype of ANDERson (1958) (Coll. ? E. L. PACKARD)

CAS. holotype and paratype of Prionotropis casperi ANDERSON (1958, pl. 34 , fig. 6 ; pl. 39 , figs. 3 , 4), from loc. CAS. $445 \mathrm{~A}$

\begin{tabular}{|c|c|c|c|c|}
\hline Specimen & Diameter & Height & Breadth $(\mathrm{B} / \mathrm{H})$ & Umbilicus $(\%)$ \\
\hline CAS. 48 & 67.5 & 27.2 & $22.8 \quad(0.84)$ & $24.2 \quad(36)$ \\
\hline UC. 12105 & 73.0 & 30.3 & $24.5 \quad(0.81)$ & $27.0 \quad(37)$ \\
\hline CAS. (casperi) & 92.0 & 37.5 & $27.0 \quad(0.75)$ & 30.0 \\
\hline Holotype of $C$. cristatun & $m 44.0$ & 17.6 & $13.2 \quad(0.75)$ & $15.0 \quad(34)$ \\
\hline
\end{tabular}

Diagnosis.-The shell is of moderate size, rather evolute, and fairly widely umbilicate. The whorl is subrectangular in cross section, somewhat higher than broad, parallel and flattened on the flanks and keeled on the venter.

The ribs are normally simple, fairly widely spaced, about twenty per whorl, nearly rectiradiate or slightly prorsiradiate on the flank and projected on the venter. Each rib has a bullate umbilical, double ventrolateral and a siphonal tubercles. The row of the latter forms a serrated keel. The ventrolateral tubercles are essentially clavate, but sometimes look nodose. The ribs are generally uniform in size, length, and distance, but a few are slightly more slender than others, with weakened umbilical bullae and may approach the adjacent stronger umbilical tubercle. On the inner whorls the ribs are finer.

The suture is relatively simple, $\mathrm{E}$ is broad and fairly deep; the saddle between $\mathrm{E}$ and $\mathrm{L}$ is subquadrate in general outline and unequally bifid; $\mathrm{L}$ is deep and relatively narrow; the saddle between $L$ and $U_{2}$ is much smaller than that between $\mathrm{E}$ and $\mathrm{L} ; \mathrm{U}_{2}$ is small; the auxiliaries are not numerous. The minor

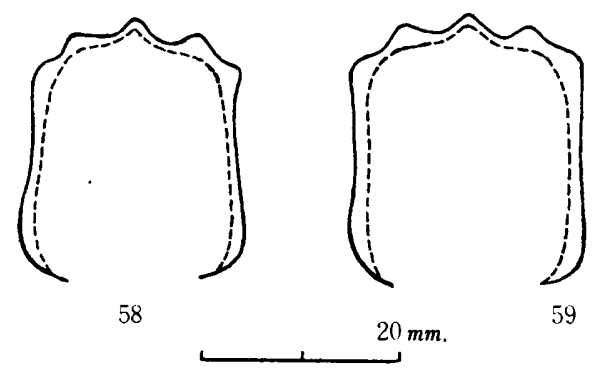

Figs. 58, 59. Subprionocyclus branneri (ANDERSON). Whorl-sections.

58. Lectotype, CAS. 48, from loc. CAS. 445A, FITCH ranch, near Phoenix, Oregon.

59. Another example, UC. 12105, from FITCH ranch, near Phoenix, Oregon. 
dentations are small and shallow.

Remarks.-The character of the full-grown shell of this species is not fully known, but the lectotype has the last suture at a diameter of about $65 \mathrm{~mm}$. and its body whorl is partly preserved. On this and another relatively large specimen the doubling of the ventrolateral tubercles is kept, without showing large hornlike tubercles of $C$. woollgari type and without weakening of the inner ventrolateral tubercles as in Subprionocyclus neptuni. The nearly rectangular whorl section and the moderately strong, instead of very coarse, ribbing are also criteria for distinguishing this species from Collignoniceras woollgari (MANTELL). It differs from $S$. neptuni (GEINITZ) in its wider umbilicus, less involution, less compressed whorl, coarser ornament, the predominance of simple over paired ribs, and its more persistent double ventrolateral tubercles.

BILlinghuRst remarked that Prionotropis branneri ANDERson (1902) is probably closely allied to Frionotropis cristatus BILlinghurst (1928, p. 515, pl. 16, fig. 3a-c) from the Chalk Rock of England. On studying both the British and American specimens, I am strongly inclined to suggest that the species are identical. The only objection may be that the holotype of the British species is not quite identical with the lectotype of the American species in the more frequent occurrence of the paired ribs in the former than in the latter. There is, however, variability in this respect both in the British and American materials. On some of the British specimens, which WRIGHT and WRIGHT (1952, p. 30) called Collignoniceras cristatum, the simple ribs are predominant as on the examples of $C$. branneri of Oregon. The holotype and other examples of Prionotropis casperi ANDERSON (1958, p. 262, pl. 34, fig. 6; pl. 39, figs. 3, 4) from Oregon, on the other hand, has some paired ribs as in BILLINGHURST's and Woods' examples of cristatum. They came from the same locality CAS. 445A. I do not know precisely whether CAS. $445 \mathrm{~A}$ represents a limited stratigraphical unit or contains several beds of somewhat different levels. It may be possible eventually to separate subspecies as follows:

C. branneri branneri, having more predominantly simple ribs

C. branneri cristatum $[=C$. casperi], having a significant number of paired ribs

The available material, however, is not enough to confirm the suggested subspecific separation and further subzonal collecting is necessary.

The above mentioned variability is important, because the present species is rather intermediate in this and other respects between Collignoniceras woollgari (MANTELL) of Middle Turonian and Subprionocyclus neptuni (GEINITZ) of Upper Turonian. In fact Prionotropis cristatus BILLINGHURST was once assigned by WRIGHT and WRIGHT (1951) to Collignoniceras and then by WRIGHT and MATSUmoto (1954) to Subprionocyclus. It may be a matter of convention to decide the generic reference to either of these alternatives. So far as the available material is concerned, Subprionocyclus is given the preference over Collignoniceras, because the outer ventrolateral tubercles keep distinctness even on the outer whorl. On the adult whorl of Collignoniceras and Prionocyclus 
they are much weakened and finally absorbed by the horn-like, inner ventrolateral tubercles.

Occurrence.-Loc. CAS. 445A, FITCH ranch [=SMITH ranch], west of Phoenix, southwest Oregon. The stratigraphic position of this locality is not accurately known. Otoscaphites perrini (ANDERSON) and Hyphantoceras (?) ceratopse (ANDERSON) occur from the same loc. CAS. 445A.

The recorded occurrence is too solitary. In view of the interregional importance as discussed above, the stratigraphical and geographical distribution of this interesting species needs to be clarified.

\section{Subprionocyclus neptuni (GEINITZ)}

Pl. 29, figs. 2, 3a, b; Pl. 30, figs. 1a-c, 2a, b; Text-figs. 60a, b, 61a, b, 62, 63

1849. Ammonites neptuni GeINITZ, Das Quadersandstein oder Kreidegebirge in Deutschland, pl. 3, fig. 3.

1872. Ammonites neptuni, GeINITZ, Palaeontographica, vol. 20, p.85, pl.36, fig. 4.

1872. Ammonites neptuni, SchLüter, Palaeontographica, vol. 21, p. 36, pl.11, figs. 1-7.

1872. Ammonites neptuni, Fritsch, Cephalopoden der böhmischen Kreideformation, p. 30, pl. 3, fig. 4.

1896. Prionocyclus neptuni, Woods, Quart. Jour. Geol. Soc. London, vol.52, p. 77. pl. 2, fig. 11; pl. 3, figs. 1, 2, 4 (non fig. 3).

1902. Schloenbachia siskiyouensis Anderson, Proc. Calif. Acad. Sci., 3rd ser., vol. 1, no. 1, p. 119, pl.1, figs. 19, 20 .

1902. Schloenbachia knighteni Anderson, Proc. Calif. Acad. Sci., 3rd ser., vol. 1, no. 1, p. 119, pl.1, figs. 1-4; pl. 2, figs. 39, 40.

? 1907. Prionotropis neptuni, PERvinquière, Études de paléontologie tunisienne, 1, céph. terr. second., p. 254.

1931. Prionotropis neptuni, Collignon, Ann. Géol. Serv. Mines, Madagascar, fasc. 1, p. 24, pl. 4, figs. 1, 1a, 1b, 2.

1951. Prionocyclus neptuni, Wright and Wright, Palaeontogr. Soc., 1950, p. 30.

1954. Subprionocyclus neptuni, Wright and Matsumoto, Mem. Fac. Sci., Kyushu Univ., ser. D, Geol., vol. 4, no. 2, p. 129.

1958. Oregoniceras knighteni, Anderson, Geol. Soc. Amer., Memoir 71, p. 264, pl. 24, fig. 5, 5a, 5b; pl. 33, figs. 1 , 1a, 3 (non ? 2).

1958. Oregoniceras siskiyouense, ANDERSON, Geol. Soc. Amer., Memoir 71, p. 266, pl. 23, figs. 2, 3; pl. 24, figs. 1, 1a, 2, 3 .

? 1958. Oregoniceras jillsoni, Anderson, Geol. Soc. Amer., Memoir 71, p. 267, pl. 19, fig. 6, 6a.

Types.-GEINITZ (1849) established the present species on apparently more than one specimens. The figured specimen (GEINITZ, 1849, pl. 3, fig. 3) is here designated as the lectotype. It came from "dem Plänerkalke von Strehlen, Sachsen, Mittler Quadermergel”, Turonian. I have not seen GEINITZ's original specimens, but saw the hypotypes of WooDs (1896) and also WRIGHT and WRIGHT (1951).

Material.-I refer to the present species a considerable number of specimens from California and adjacent areas. The examples are as follows: 
A well-preserved (UC. 31501) (Pl. 30, fig. 2a, b; Text-fig. 60a, b) and another (UC. 31438) (Text-fig. 61a, b) adult shells and an immature one (UC. 35694) (Pl. 30, fig. 1a-c) from loc. SOC. K-221 (Coll. M. V. KIRK)

UCLA. 28781 (Pl. 29, fig. 3a, b), UCLA. 28782 (Pl. 29, fig. 2), and several others from loc. CIT. 1042 (Coll. W. P. Popenoe \& W. A. Findlay)

Several specimens (UCLA.) from loc. CIT. 1062 (Coll. W. P. Popenoe)

A specimen (UCLA.) from loc. CIT. 1266 (Coll. W. P. Popenoe)

CAS. 25, one of the syntypes of Schloenbachia siskiyouensis ANDERson (1902, pl. 1, figs. 19, 20), erroneously called the neotype by ANDERsoN (1958, pl. 24, fig. 3), and other examples of "Oregoniceras siskiyouense ANDERSON” (1958, pl. 24, figs. 1, 1a, 2) from loc. CAS. 445

Two of the syntypes of Schloenbachia knighteni ANDERson (1902, pl. 1, fig. 1), which were incorrectly figured as one, from loc. CAS. 445 (see also ANDERSON, 1958, pl. 24, fig. 5, which was illegitimately called the holotype) (CAS. Coll. F. M. ANDERson)

Other syntypes of Schloenbachia knighteni ANDERson (1902, pl. 1, figs. 2-4; pl. 11, figs. 39, 40) (see also ANDERSon, 1958, pl. 35, figs. 1, 1a, 3) (CAS. Coll. F. M. ANDERSON)

In addition to the above, there are many, relatively poorly preserved, comparable specimens.

\begin{tabular}{|c|c|c|c|c|}
\hline Specimen & Diameter & Height & Breadth $(\mathrm{B} / \mathrm{H})$ & Umbilicus $(\%)$ \\
\hline UC. 31501 & 109.0 & 47.5 & $34.8 \quad(0.73)$ & $32.5 \quad(29)$ \\
\hline$\prime \prime \quad$ (intercostal) & - & 42.0 & $32.0 \quad(0.78)$ & - \\
\hline UC. 31438 & 92.5 & 39.0 & $31.9 \quad(0.81)$ & $27.5 \quad(29)$ \\
\hline UCLA. 28782 & 62.5 & 29.2 & $20.7 \quad(0.70)$ & $17.6 \quad(28)$ \\
\hline UCLA. 28781 & - & 27.5 & $19.3 \quad(0.70)$ & - \\
\hline Another from CIT. 1042 & $2-$ & 34.5 & $23.0 \quad(0.66)$ & - \\
\hline Another from CIT. 1042 & 24.7 & 11.2 & $7.2 \quad(0.64)$ & $7.2 \quad(29)$ \\
\hline Another from CIT. 1042 & 80.0 & 27.2 & - & $20.0 \quad(25)$ \\
\hline One from CIT. 1062 & 一 & 33.8 & $20.5 \quad(0.60)$ & - \\
\hline One from CIT. 1266 & 34.5 & 16.5 & $10.0 \quad(0.60)$ & $9.0 \quad(26)$ \\
\hline $\begin{array}{l}\text { CAS. } 25 \\
\text { ("S. siskiyouensis") }\end{array}$ & 45.0 & 21.7 & $15.3 \quad(0.70)$ & $11.3 \quad(25)$ \\
\hline $\begin{array}{l}\text { CAS. ("S. knighteni") } \\
\text { (deform.) }\end{array}$ & 66.4 & 30.0 & $18.8 \quad(0.63)$ & $18.8 \quad(28)$ \\
\hline $\begin{array}{l}\text { CAS. ("S. knighteni") } \\
\text { (deform.) }\end{array}$ & - & 41.0 & $26.0 \quad(0.63)$ & - \\
\hline $\begin{array}{c}\text { GSM. } 37235 \text { (Woods, } \\
1896 \text {, pl. } 3 \text {, fig. } 2 \text { ) }\end{array}$ & 32.8 & 14.0 & $8.0 \quad(0.57)$ & $10.0 \quad(31)$ \\
\hline C. W. Wright 21325 & - & 25.3 & $16.3 \quad(0.64)$ & - \\
\hline
\end{tabular}

Diagnosis.-The full-grown shell is of moderate size, but in many cases relatively small specimens are common. It is considerably involute and its umbilicus is fairly narrow or of moderate size. The whorl is compressed, relatively more so in the young stages than in the late ones. The proportion of breadth to height is 0.7 (on average) \pm 0.1 . The flanks are only slightly convex, roughly parallel on the main part, and tend to be slightly convergent toward the venter. The maximum breadth is between the umbilical tubercles in 
the costal section, but may be at the mid-flank in the intercostal section. The umbilical wall is low but steep, often nearly vertical, and has a subangular shoulder. The whorl is shouldered at the ventrolateral point and has a serrated keel at the mid-venter.

The ribs are gently sigmoidal and somewhat prorsiradiate, normally springing in pairs from the umbilical tubercles. Double tubercles are developed on all the ribs at the ventrolateral shoulder, of which the inner one is often nodose and may be weakened on the outer whorl and the outer one is distinctly clavate. The serration on the keel corresponds to each rib, being situated somewhat forward from the outer ventrolateral clava; the connecting weak ribs form a more or less acute chevrons on the venter. The ribs and tubercles are relatively fine on the inner, young whorl, moderately coarse on the main part of the whorl of the middle growth-stage, and flattened or weakened on the adult body whorl. The density of the ribs vary also by individuals. On the outer whorl the secondary ribs may become intercalatory.

The suture is relatively simple, being incised by small dentations. $\mathbf{E}$ is moderately broad; the saddle between $\mathrm{E}$ and $\mathrm{L}$ is broad, subquadrate to dome

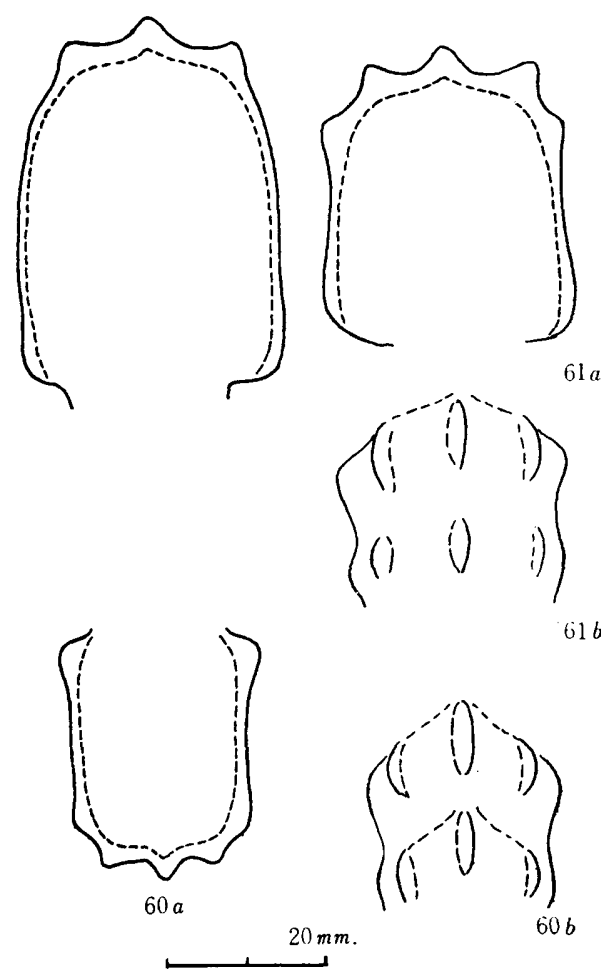

Figs. 60, 61. Subprionocyclus neptuni (GerNitz). Whorl-sections (a) and ventral ornaments (b) of two mature shells.

60. UC. 31501, from loc. SOC. K-221, Swede Creek, Redding area, Shasta County. See Pl. 30, fig. 2a, b for other views.

61. UC. 31438 , from the same loc. SOC. K-221. 
like in general outline, asymmetrically bipartite by a narrow lobule; $\mathrm{L}$ is deep, generally narrow, but may be broadened on the last part, and variably bi- or tripartite; the saddle between $\mathrm{L}$ and $\mathrm{U}_{2}$ is asymmetric, and higher but narrower than the external one; $U_{2}$ is small and narrow; the auxiliaries are not numerous.

Variation.-On studying the examples from the Upper Turonian of England, I noticed a great variability of this species in the involution and compression of the whorl, density and flexuosity of the ribs, strength of tubercles, etc. Other European examples, as illustrated by GEINITZ (1849, 1872), Fritsch (1872), and SCHLÜTER (1872), suggest a similar feature, although some of them seem to have been secondarily deformed. Collignon (1931, p. 24, pl. 4, figs. 1, 1a, 1b, 2) clearly demonstrated the high variability of this species from the examples from Madagascar. The same is true for the examples from California and Oregon.

The three specimens from loc. SOC. K-221 are well preserved but differ from one another. The illustrated, adult shell (UC. 31501) is rather typical in every respect, although the ribs are apparently coarser than those of the lectotype from Germany. This difference may be due to change of characters with growth, because I have seen a general tendency that the ribs are finer and the whorl is more compressed in the immature shell than in the mature one. The second specimen, UC. 31438, which is as large as the first one, has more rectangular whorl-section (Text-fig. 61a), less flexuous and more distant ribs, on which the lower ventrolateral tubercles persist for a longer period than that. In spite of relatively coarse ribbing on the outer whorl, this specimen has fine

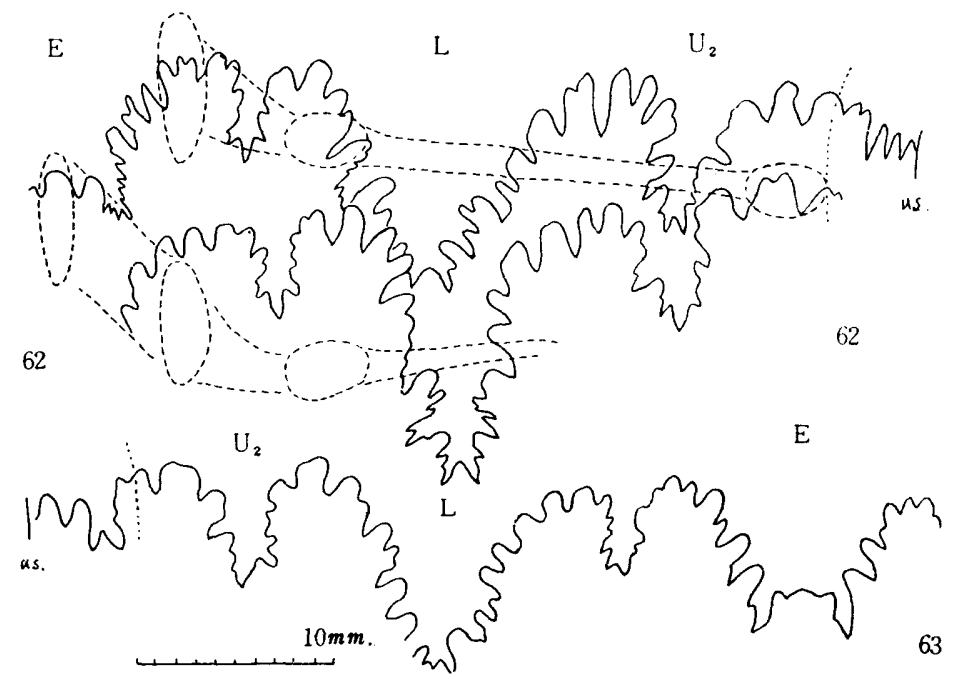

Figs. 62, 63. Subprionocyclus neptuni (GeINITZ). External sutures of two mature whorls.

62. The last third and fourth sutures of a specimen, UC. 31501, from loc. SOC. K-221, Swede Creek, Redding area, Shasta County. See Pl. 30, fig. $2 a, b$ and Text-fig. $60 \mathrm{a}, \mathrm{b}$.

63. The last fourth suture of another specimen, UC. 31438 , from the same loc. SOC. K-221. See Text-fig. 61a, b. 
and crowded ribs on the small, inner whorl. The third, small specimen, UC. 35694 , about $24 \mathrm{~mm}$. in diameter, probably represents the immature, shell, because it shows as fine and crowded ribs as the inner whorl of the second specimen. It is relatively compressed. On this specimen and on others as large as it, the lower ventrolateral tubercles are indistinct, foreshadowing the characters of Reesidites WRIGHT and MATsumoto, 1954. The lower ventrolateral tubercles tend to be weakened also on the whorl of relatively late growth stage. Therefore the double ventrolateral tubercles characterize the main, middle growthstage.

From loc. CIT. 1531 (=LSJU. 3291=TM. 2005) were obtained many small specimens, which are specifically indeterminable but well comparable with such immature whorls of this species as mentioned above. I collected from the same locality a few fragmentary larger whorls on which double ventrolateral tubercles are shown. Therefore the specimens from this locality are most reasonably referable to Subprionocyclus sp., if not exactly called S. neptuni (GEINITZ) juvenile.

A considerable number of specimens from loc. CIT. 1042, Siskiyou County, northern part of California show similarly variation in the involution and compression of whorls, density and coarseness of the ribs, distinctness of the lower ventrolateral tubercles, etc. In this general area and adjacent part of southwestern Oregon, ANDERSON established a large number of species under Schloenbachia in 1902 and under Oregoniceras in 1958. Some of his types are unfortunately too small for specific distinction, because the immature shells alone are not enough for defining the specific diagnosis. Schloenbachia oregonensis ANDERSON is such an example. Some others are, however, large and sufficient for comments. Among them the types of "Oregoniceras siskiyouense (ANDERSON)" (1958, p. 266, pl. 23, figs. 2, 3; pl. 24, figs. 1, 1a, 2, 3) are certainly within the range of variation of Subprionocyclus neptuni (GEINITZ) ; its original type (holotype ?) (CAS. 25) (ANDERSON, 1902, p. 119, pl. 1, figs. 19, 20) is a typical example of $S$. neptuni, being close to GEINITZ's illustrated type (lectotype of $S$. neptuni).

The available evidence proves that Oregoniceras knighteni (ANDERSON) is also specifically identical with Subprionocyclus neptuni (GEINITZ). ANDERSON established Schloenbachia knighteni on several syntypic specimens (1902, p. 119, pl. 1, figs. 1-4; pl. 2, figs. 39, 40). A fragmentary body whorl and another somewhat smaller, but better preserved shell were united in one figure (ANDERSON, 1902, pl. 1, fig. 1), that shows incorrectly an evolute shell. Actually they do not fit to each other, but represent different individuals. The former is probably a relatively flattened and multicostate variety, on the body whorl of which the lower ventrolateral tubercles are much weakened. The latter belongs rather to a typical form of Subprionocyclus neptuni, although on its outer whorl the lower ventrolateral tubercles are considerably weakened. Other specimens described by ANDERSON under the specific name knighteni are small, but well comparable with the inner whorls of relatively widely umbilicate and flattened variety of S. neptuni, 
like some British, as well as other Californian, examples. Since these variants are gradational to and associated with the typical form, separation into different species is not natural. ANDERSON described that the ribs of knighteni as simple and almost straight, but his original specimens actually show flexuous ribs which essentially spring in pairs from the umbilical tubercles but sometimes have intercalated secondaries.

Oregoniceras jillsoni ANDERson (1958, p. 267, pl. 19, fig. 6, 6a) is not distinct enough for specific separation from Subprionocyclus neptuni. Its holotype is a fragmentary body whorl, which is comparable with the last portion of the adult specimen from loc. K-221 (see above), although the double ventrolateral tubercles are better kept on ANDERSON's specimen. Its paratype is indistinguishable from what ANDERSON called Oregoniceras knighteni, and, accordingly, falls within the variation of $S$. neptuni.

Remarks.-Ammonites neptuni GEINITZ has received several generic names by different authors. Woods (1896) assigned it to Prionocyclus which was followed by Wright and WRIGHT (1951). The French paleontologists, PervinQUIÈRE (1907) and then CollignoN (1931), referred it to Prionotropis [= Collignoniceras]. ANDERSON (1902) mentioned that his Schloenbachia siskiyouensis and Schloenbachia knighteni appeared to be referable to Barroisiceras, but later (1958) assigned them to his Oregoniceras.

Shimizu (1932) set up Subprionocyclus, designating Prionocyclus hitchinensis Billinghurst (1928, p. 516, pl. 16, figs. 1a-f, 2a-b) as the type-species. This British species is unfortunately based on a few, small, probably immature 'shells and SHIMIZU's statement of the generic distinction was inadequate. WRIGHT and MAtsumoto (1954, p. 129) noticed, however, that Prionocyclus hitchinensis BILlinghurst, Ammonites neptuni GEINITZ, and their allies form a distinct group, for which the generic name Subprionocyclus should be used, with a revised definition. Actually $S$. neptuni (GeINITZ) is the best known example of this genus.

Subprionocyclus neptuni (GEINITZ) resembles in general respects the inner whorls of Collignoniceras woollgari (MANTELL) (SHARPE, 1855, p. 27, pl. 11, figs. 1, 2); in both the double ventrolateral tubercles and serrated keel are developed. While the lower ventrolateral tubercles are wakened on the outer whorl of the former, the double ventrolateral tubercles are united into prominent horns on that of the latter. Also on the outer whorl the ribs are much stronger and more distant in the latter than in the former. On the inner whorl the difference is not remarkable, but the former has more or less flexuous ribs which normally spring in pairs from the umbilical nodes, sometimes with intercalating secondaries, while the latter has nearly equally long, simple, prorsiradiate ribs. Although there is variation in shell-form, the latter is on average more evolute and more robust than the former.

Subprionocyclus neptuni (GEINITZ) is similar to Prionocyclus wyomingensis MEEK (1876, p. 452; White, 1883, p. 35, pl. 15, fig. 1) in some respects. The principal difference is that the upper ones of the double ventrolateral tubercles 
are distinct and clavate and the lower ones may be weakened on the whorl of the former, while the upper ones are very indistinct and the lower ones are strengthened on the latter. The serration of the keel is fine in the latter, being more numerous than the ribbing. In $P$. wyomingensis the ribs spring in pairs from the umbilical tubercles, as in $S$. neptuni, but there are intercalating ribs which do not have umbilical tubercles, and the ribs are rather irregularly arranged in strength, length, and curvature. In $P$. wyomingensis the weakened outer tubercles are on the ventral part, close to the keel, extending to the strongly projected ventral ribs. On average the whorl of $P$. wyomingensis is more evolute than that of $S$. neptuni.

I conclude that Ammonites neptuni GeINITz should be referred to Subprionocyclus, which is related to but distinct from both Collignoniceras and Prionocyclus. Taking all the available facts into consideration, Subprionocyclus and Prionocyclus are probably parallel derivations from Collignoniceras.

Occurrence.-Fairly common in California and Oregon: loc. SOC. K-221, presumably time-stratigraphically equivalent of Member III; locs. CIT. 1266, CIT. 1264, and (cf.) CIT. 1531 [=LSJU. 3291], relatively lower part of Member III of the Redding area, northeast side of the Sacramento Valley; locs. CIT. 1042, (cf.) CIT. 1044, and (cf.) CAS. 444A, the Hornbrook-Henley area, Siskiyou County, northern California; loc. CAS. 445, "Forty-nine", southwestern Oregon. The stratigraphic position in the last two areas are not precisely known, but PECK, IMLAY, and PoPenoe (1956) recently listed Subprionocyclus sp. from their Member I of the Hornbrook formation. Loc. CIT. 1062, upper part of the Baker Canyon sandstone member in the Santa Ana Mountains, where Sciponoceras sp. aff. S. bohemicum (FRITSCH) is associated.

The species is known in the Upper Turonian of England, Germany and adjacent areas of Europe, Madagascar and also Japan.

\section{Subprionocyclus normalis (ANDERSON)}

Pl. 29, fig. 1a, b; Pl. 31, figs. 1a-d, 2a-d, 3, 4a, b, 5a, b;

Text-figs. 64a, b, 65, 66a, b

1958. Oregoniceras normale ANDERson, Geol. Soc. Amer., Memoir 71, p. 268, pl. 25, fig. 8, 8a.

Holotype.-The specimen (CAS. Coll.) designated and illustrated by ANDERsoN (1958, p. 268, pl. 25, fig. 8, 8a). It came from "Forty-nine mine, 2 miles south of Phoenix, Oregon".

Material.-In addition to ANDERson's specimens, there are a large number of specimens in the recent collections. The better preserved examples are as follows :

UCLA. 28783 (Pl. 31, fig. 2a-d), UCLA. 28784 (Pl. 31, fig. 1a-d), UCLA. 28785-28795, from loc. CIT. 1346 (Coll. W. P. POPENOE \& J. HoEL)

GK. H 7038-7046 (Pl. 31, figs. 3, 4, and 5 for GK. H 7040, H 7041, and H 7038 and Pl. 29, fig. 1 for $\mathrm{H} 7046$ ) from loc. TM. 2001=LSJU. 3288 (Coll. W. P. Popenoe \& T. Matsumoto) 
LSJU. 8584-8587 from loc. LSJU. 2711 (Coll. W. P. Popenoe)

LSJU. 8588-8591, LSJU. 8601 from loc. LSJU. 2735 (Coll. L. F. FUNK HOUSER)

GK. H 7047 from loc. TM. $7001=$ CIT. 79 (Coll. Peter RoddA, W. P. PoPENOE \& T. MATSUMOTO)

In every case of the above localities, there are still more unlisted specimens.

Measurements.-

\begin{tabular}{|c|c|c|c|c|c|c|}
\hline Specimen & Diameter & Height & Breadth $(\mathrm{B} / \mathrm{H}) \quad \mathrm{Umb}$ & bilicus & $(0 \%)$ & $\begin{array}{l}\text { Tubercles } \\
\text { umbilical/ } \\
\text { ventral }\end{array}$ \\
\hline Holotype (CAS.) & 42.2 & 22.0 & $11.8 \quad(0.53)$ & 9.5 & $(22)$ & $11 / 27+? 2$ \\
\hline GK. H 7038 & 45.0 & 21.0 & $6.0 \times 2(0.57)$ & 11.5 & $(25)$ & $10 / 28$ \\
\hline GK. H 7039 & 31.0 & 13.5 & $8.0 \quad(0.59)$ & 9.0 & (29) & $10 / 23$ \\
\hline GK. H 7040 & 29.0 & 13.5 & 5.0 (second. def.) & 7.5 & $(26)$ & $10 / 23$ \\
\hline GK. H 7041 & 28.0 & 14.0 & $8.5 \quad(0.60)$ & 5.7 & $(20)$ & $10 / 25$ \\
\hline GK. H 7042 & 34.0 & 17.0 & $10.0 \quad(0.58)$ & 7.0 & $(20)$ & $9 / 20+? 4$ \\
\hline GK. H 7043 & 31.3 & 14.3 & $8.0 \quad(0.56)$ & 6.3 & $(20)$ & $9+0 / 26$ \\
\hline GK. H 7046 & c. 65.0 & 27.8 & $8.0 \times 2(0.57)$ & 18.0 & $(27)$ & $5 / 12$ per $/$ whorl \\
\hline UCLA. 28783 & 44.0 & 23.5 & $12.5 \quad(0.53)$ & 6.8 & $(15)$ & $8 / 29$ \\
\hline UCLA. 28784 & 36.0 & 18.5 & $9.3 \quad(0.50)$ & 7.4 & $(20)$ & $9 / 23$ \\
\hline UCLA. 28785 & 42.5 & 20.0 & $11.0 \quad(0.55)$ & 10.0 & $(23)$ & $9 / 23$ \\
\hline UCLA. 28786 & 34.2 & 16.9 & $9.5 \quad(0.56)$ & 7.8 & $(22)$ & $9 / 24$ \\
\hline UCLA. 28787 & 35.0 & 16.8 & $9.0 \quad(0.53)$ & 8.5 & $(24)$ & $11 / 26 ? \pm 1$ \\
\hline UCLA. 28788 & 26.7 & 11.8 & $6.8 \quad(0.57)$ & 7.2 & $(27)$ & $10 / 24 ? \pm 1$ \\
\hline UCLA. 28789 & 28.7 & 13.4 & c. $8.5 \quad(0.63 ?)$ & 7.8 & $(27)$ & $10 / 22$ \\
\hline UCLA. 28790 & 26.3 & 13.0 & $6.8 \quad(0.52)$ & 6.0 & $(21)$ & $11 / 34$ \\
\hline UCLA. 28791 & 25.0 & 11.7 & $6.8 \quad(0.58)$ & 5.9 & (23) & $8+0 / 19+? 2$ \\
\hline UCLA. 28792 & 25.5 & 11.3 & $6.8 \quad(0.60)$ & 7.1 & $(27)$ & $13 / 27+? 2$ \\
\hline UCLA. 28793 & 20.5 & 9.1 & $6.0 \quad(0.65)$ & 5.5 & $(27)$ & $8+0 / 24+0$ \\
\hline UCLA. 28794 & 17.3 & 7.5 & $4.5 \quad(0.60)$ & 5.3 & $(30)$ & $10+0 / 35+0$ \\
\hline UCLA. 28795 & 15.0 & 7.0 & $4.2 \quad(0.60)$ & 3.8 & $(25)$ & $8+0 / 20+0$ \\
\hline LSJU. 8584 & 36.1 & 18.2 & $9.6 \quad(0.52)$ & 8.2 & $(23)$ & $7 / 24$ \\
\hline LSJU. 8585 & 33.8 & 16.5 & $9.2 \quad(0.55)$ & 6.4 & (19) & $8 / 23$ \\
\hline LSJU. 8586 & 27.5 & 11.7 & $7.5 \quad(0.64)$ & 8.5 & $(30)$ & $11 / 24+? 1$ \\
\hline LSJU. 8587 & 23.4 & 9.8 & $6.4 \quad(0.65)$ & 6.6 & (28) & $12 / 24$ \\
\hline LSJU. 8588 & 37.3 & 19.5 & 8.8 (second. def.) & 8.0 & $(21)$ & $12 / 32$ \\
\hline LSJU. 8589 & 30.7 & 14.0 & - & 8.5 & $(27)$ & $11 / 28$ \\
\hline LSJU. 8590 & 24.0 & 10.5 & $6.0 \quad(0.57)$ & 7.3 & $(30)$ & $14 / 35$ \\
\hline $\begin{array}{l}\text { One from loc. } \\
\text { LSJU. } 3288\end{array}$ & 70.0 & 33.3 & 14.5 (second. def.) & 9.2 & $(23)$ & $9 /-$ \\
\hline \multicolumn{7}{|l|}{ For comparison: } \\
\hline $\begin{array}{l}\text { CAS. } \\
\text { (O. phoenixense })\end{array}$ & 39.3 & 18.2 & $9.3 \quad(0.51)$ & 9.2 & $(23)$ & $11 / 33$ \\
\hline $\begin{array}{l}\text { CAS. } 36 \\
(O . \text { oregonense })\end{array}$ & 43.2 & 17.8 & $10.0 \quad(0.56)$ & 12.5 & $(29)$ & $18 / 46$ \\
\hline
\end{tabular}

Diagnosis.-The shell is fairly small; the largest example is $70 \mathrm{~mm}$., but many specimens that are probably adult are below $50 \mathrm{~mm}$. in diameter. It is considerably involute and grows rapidly; consequently the umbilicus is fairly narrow. The whorl is much higher than broad, the proportion of breadth to height being mostly 0.5-0.6; the umbilical wall is low and steep, but not vertical; the umbilical shoulder is subrounded; the flanks are flattened, or only slightly convex, and roughly parallel or slightly convergent; the venter is narrow, 
shouldered at the ventrolateral point, fastigate towards the narrow median keel.

The ribs are flexuous, springing in pairs from the prorsiradiate umbilical bullae. There are also intercalating secondary ribs. All the ribs are provided with ventrolaterai and medioventral clavi, forming acute chevrons on the venter; the lower ventrolateral tubercles are small, indistinct, and discernible on the whorl of a relatively limited period of the middle growth-stage. The ribs are moderate in intensity and density, being separated by interspaces which are nearly as narrow as the ribs themselves. On the last part of the adult body whorl, the ribs, tubercles, and keel are much weakened.

The suture is generally of the same pattern as that of Subprionocyclus neptuni (GEINITZ) (see the description), but its saddles are more slender, its lobes are narrower and deeper, and minor incisions are sharper than in the corresponding growth-stage of the latter. The saddle between $\mathrm{E}$ and $\mathrm{L}$ is very asymmetric.

Variation.-From a large number of specimens from one and the same locality, a considerable extent of variation is recognized. The measurements above listed may demonstrate the situation. The ratio of umbilicus to diameter, for instance, ranges from 15 to 30 percent, although it is commonly 20-27 percent. The proportion of whorl breadth to height again extends fairly widely, although it is normally less than 0.7 and commonly 0.5-0.6.

The ribs begin to appear sooner or later at a shell diameter of about $10 \mathrm{~mm}$. The number of the ribs per whorl differs by individuals and also by growthstages. Because of branching and intercalation, the ribs (or tubercles) on the ventral part are two to three times as numerous as the umbilical bullae. The

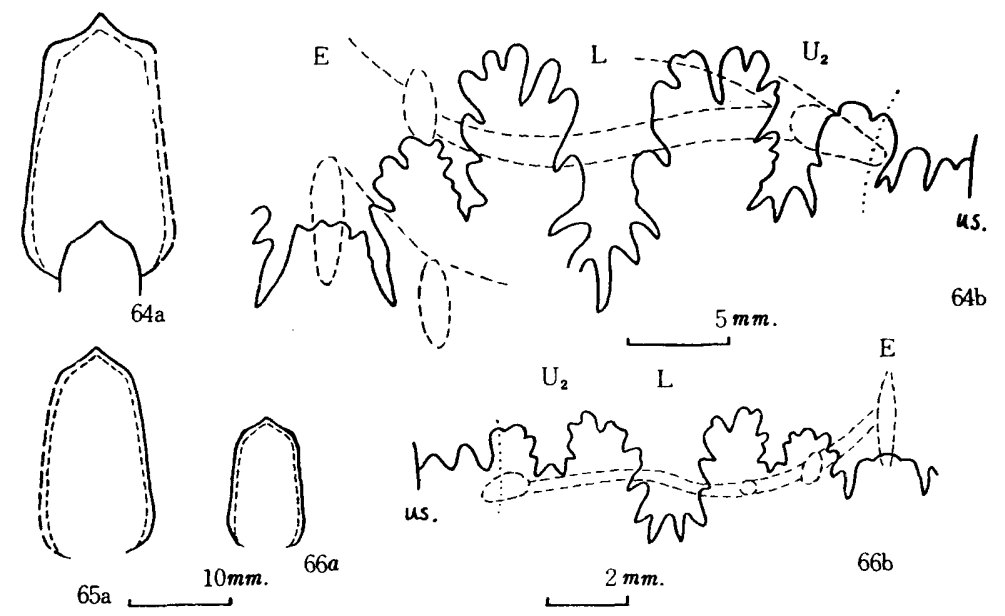

Figs. 64-66. Subprionocyclus normalis (ANDERSON). Whorl-sections (a) and sutures (b).

64. GK. H 7046, from loc. TM. 2001 [=LSJU. 3288], Member III of the Redding area, Shasta County. See Pl. 29, fig. 1a, b.

65. GK. H 7038, from the same loc. TM. 2001. See Pl. 31, fig. 5a, b.

66. GK. H 7039, a small specimen, from loc. TM. 2001. 
number of the umbilical bullae ranges from 7 to 14 , being commonly 9-12 and that of the ribs (or ventral tubercles) ranges from 22 to 35 per whorl. Thus the shell is normally ornamented by ribs of moderate distance and fineness, but is sometimes considerably multicostate, if not densicostate.

Remarks.-This species is intimately allied to Subprionocyclus neptuni (GEINITZ). In fact the extreme end member (e.g. UCLA. 28789) of the former approaches closely to that of the latter. Generally speaking, however, the former is smaller, more compressed, more involute, and more narrowly umbilicate and has more fastigate venter, weaker ornament, shorter period of duble ventrolateral tubercles, and more slender elements of suture.

In these respects the present species is close to Reesidites minimus (HAYASAKA and FUKADA) (1951, see WRIGHT and MATSumoto, 1954, p. 130). The relationship is so intimate that Subprionocyclus normalis may be regarded as intermediate between Subprionocyclus neptuni and Reesidites minimus, which in turn may give rise to Barroisiceras spp. The complete absence of the double ventrolateral tubercles at any growth stage is a criterion to distinguish Reesidites from Subprionocyclus. From the intimate resemblance of $S$. normalis and $R$. minimus, it might be suggested that Reesidites would be better classified as a subgenus of Subprionocyclus. Someone might hold the view that Reesidites could be regarded as a subgenus of Barroisiceras. This is not the place to discuss further, because the available material of California is not sufficiently continuous for tracing the evolutional change. Anyhow the present species is important for the question.

The description of the present species depends much on a large number of specimens from a limited portion of the stratigraphic succession. I was inclined to give a new specific name for them, before I saw ANDERson's (1958) monograph. The typical example of the present species just fits the holotype of Oregoniceras normale ANDERSON (1958, p. 268, pl. 25, fig. 8, 8a), so that his specific name should be used. In addition to this ANDERSON (1958) described a large number of species under Oregoniceras. As I have already mentioned, some of them, especially Oregoniceras siskiyouense (ANDERSON) and O. knighteni (ANDERSON), fall in the synonymy of Subprionocyclus neptuni (GEINITZ). Others are, however, based on too imperfect or too small specimens to judge clearly their specific identity with or distinction from the species already known. Possibly O. phoenixense ANDERSON (1958, p. 266, pl. 25, fig. 7, 7a; pl. 33, fig. 6, 6a), may be merely a multicostate variety of Subprionocyclus normalis (ANDERSON). Nomenclatorially the former would preoccupy the latter in page, but until the specific identity can be confirmed $S$. normalis should be used for the specimens described in this paper.

Schloenbachia oregonensis ANDÉRSON (1902, p. 122, pl. 2, fig. 48) was designated as the type species of Oregoniceras ANDERSON (1958, p. 263). Its holotype, CAS. 36 from loc. CAS. 445 , is again a small specimen, which is characterized by dense and numerous ribs. Its whorl is nearly as compressed as that of S. normalis, but its multicostation is beyond the limit of variation 
of the latter (see measurements). The doubling of the ventrolateral tubercles is not clear on the holotype of $O$. oregonense and even on the immature whorls of Subprionocyclus neptuni and other related species. In fact the holotype of S. hitchinensis Billinghurst (1928, p. 516, pl. 16, figs. 1a-f, 2a-b) resembles in many respects that of $O$. oregonense. From the available material, however, I cannot decide accurately whether $O$. oregonense belongs to Subprionocyclus or to Reesidites. Anyhow Oregoniceras ANDERson, 1958 is a synonym of either Subprionocyclus ShImizu, 1932 or Reesidites Wright and MATSUmoto, 1954. I hope that further, careful, subzonal field work will provide us with better evidence for clearing this and other points.

Occurrence.-Abundant at localities CIT. 1346, CIT. 1346A, TM. 2001= LSJU. 3288, Little Cow Creek, in the middle to upper part of Member III of POPENOE (1943), Redding area, northeastern side of the Sacramento Valley, California. Comparable specimens occur fairly commonly at localities CIT. 79 [=TM. 7001], CIT. 978 and CIT. 1164, top of Baker Canyon sandstone or basal part of Holtz shale member in the Santa Ana Mountains, California. So far as the available records are concerned, $S$. normalis occurs at slightly higher level than $S$. neptuni, and is a good indicator of the horizon.

The two species were reported to occur at CAS. 445, "Forty-nine mine", southwest Oregon, but their stratigraphic positions are not clear. The specimens of S. normalis and certain others of ANDERSON's Oregoniceras are coated with dark green matter, while those of $S$. neptuni (=O. siskiyouense, O. knighteni, etc.) are not green. This suggests that loc. CAS. 445 may include fossils of more than one level.

\section{Subfamily Peroniceratinae HyATT, 1900}

Representatives of Peroniceratinae nccur very sparsely in California. They have been already described by GABB $(1864,1869)$ and ANDERSON $(1902,1958)$. As I had opportunity of seeing most of their original specimens I give here short comments.

The holotype of Prionocycloceras crenulatum (ANDERSON) (1902, p. 125, pl. 1, figs. 17, 18) was lost in the San Francisco fire and a neotype has been unofficially proposed by ANDERSON (1958, p. 263, pl. 34, fig. 5, 5a). According to ANDERSON they came from RICHARDSON's ranch, 4 miles north of Montague, Siskiyou County. The locality should be within the Hornbrook formation of Peck, Imlay, and Popenoe (1956), despite their suggestion that the Lower Senonian may be absent in the Hornbrook formation.

ANDERSON's neotype has a finely crenulated, prominent, ventral keel, coarse ribs, strong ventrolateral and umbilical tubercles. The ventrolateral tubercles are not doubled and the whorl-section is quadrangular. This species is, thus, a representative of Prionocycloceras in California. Another species Prionocyclus californicus ANDERSON (1958, p. 262, pl. 69, fig. 4, 4a, 4b) is questionable. Its holotype is too fragmentary and too young for a precise generic assignment, 
but is probably an example of Prionocycloceras. It came from loc. CIT. 1034, Oak Run, Member IV of the Redding area, associated with the holotype of Peroniceras shastense ANDERson (1958, p. 260, pl. 69, fig. 5, 5a, 5b, 5c) (Coll. POPENOE \& FINDLEY). The latter is so poorly preserved that its distinction from other well known species of Peroniceras is not clear.

At loc. CIT. 1007, Oak Run, from the same member IV of the Redding area, W. P. Popenoe and D. ScharF obtained a small but well preserved ammonite (Pl. 31, fig. 6a, b), which I regard as an immature shell of Peroniceras sp. Its whorl is evolute, broader than high, and subquadrate in section, with a distinct, ventral keel accompanied on each side by a groove and then a faint elevation. The last is at the end of the ventral projection of the ribs and presumably develops to a more distinct keel on the outer whorl. The ribs are mostly simple, rarely bifurcating, fairly distant, nearly rectiradiate on the flank, and provided with the bullate, umbilical and the nodose, ventrolateral tubercles.

Peroniceras tehamense (GABB) (1869, p. 132) [=Ammonites subtricarinatus, GABB (non D'ORBIGNY), 1864, p. 60, pl. 10, fig. 4, 4a] was established on at least three fragmentary specimens, UC. 12102 (Text-fig. 67), UC. 14850 (Textfig. 68), and UC. 14851, which may belong to more than one individual, and came from "the vicinity of Battle Creek, Tehama County". This species is distinguished by a subquadrate whorl-section which is broader than high, three distinct ventral keels, simple, prorsiradiate, slightly flexuous ribs, bullate umbilical and rounded ventrolateral tubercles. In these respects Peroniceras rousseauxi DE GRossouvRE (1894, p. 142, pl. 11, fig. 5), from the Coniacian of France, is very similar to and possibly identical with $P$. tehamense (GABB, 1869).

Peroniceras quintoense ANDERSON (1958, p. 260, pl. 47, fig. 1, 1a) is indefinite, because it is based on a single, large, but secondarily deformed specimen. ANDERSON illustrated only a part of the outer whorl. Its inner whorl resembles Peroniceras subtricarinatum D'ORBIGNY (1840, p. 397, pl. 91, figs. 1, 2), but its outer whorl has prorsiradiate ribs, bullate umbilical and rounded ventrolateral tubercles like that of $P$. tehamense. Anyhow it is an example of Peroniceras came from loc. CAS. 29596, a shaly unit on Quinto Creek, presumably
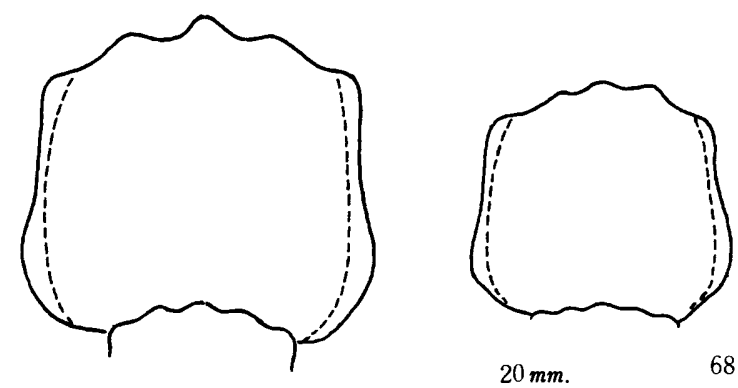

67

Figs. 67, 68. Peroniceras tehamense (GABB). Whorl-sections.

67. A body-whorl, UC. 12102, one of GABB's syntypes.

68. A septate whorl, UC. 14850, another of GABB's syntypes. 
an equivalent of the Lower Marlife formation of the Panoche group, Merced County, west side of the San Joaquin Valley.

\section{Subfamily Texanitinae Collignon, 1948}

Genus Texanites SpaTH, 1932

Type-species.-Ammonites texanus RoEMER, 1852.

Generic diagnosis.-See Collignon, 1948, p. 62.

Remarks.-I have emended CoLlignoN's definition of Texanites, separating Protexanites MATsumoto, 1955 as an ancestral genus.

Texanites is world-wide in the Santonian but begins to appear in the Upper Coniacian and persists to the Lower Campanian. In California I have recognized only one species of Texanites represented by a few, imperfectly preserved specimens.

\section{Texanites cf. kawasakii (KAWADA) \\ Pl. 28, fig. 2a, b}

\section{Compare.-}

1929. Mortoniceras kawasakii KaWADA, Jour. Geol. Soc. Tokyo, vol. 36, p. 4 (English), pl. 14, figs. 2-4.

Holotype of Texanites kawasakii.-A single specimen described and illustrated by KAWADA (1929, p. 4, pl. 14, figs. 2-4), from the Miho group of the Naibuchi area, south Sakhalin.

Material.-The described Californian examples are a fragmentary whorl, UCLA. 28847 (Pl. 28, fig. 2a, b), and two other poorly preserved specimens, from loc. UCLA. 3373 (Coll. R. W. IMLAY \& W. P. PoPENOE).

Descriptive remarks.-The Californian specimens are all fragmentary but show some characteristic features. The whorl is subquadrate, somewhat convergent, and slightly higher than broad in costal section. The ventral keel is continuous. The ribs are simple, equally long, nearly straight to slightly concave, broadened towards the venter, and provided with approximately equidistant tubercles in five rows. The bullate umbilical tubercle tends to be doubled; the lower lateral is moderately strong, the upper lateral rounded but weak, the ventrolateral strongest and clavate, and the ventral clavate and moderately high. The suture, which is partly exposed, is of Texanites type.

Texanites kawasakii (KAWADA) was established on a single, probably immature whorl. There are two more specimens of this species in the collection of the University of Tokyo from the same Miho group, south Sakhalin and another from the Santonian of Hokkaido in the collection of Kyushu University. Two of them are more than $100 \mathrm{~mm}$. in diameter. The Californian example illustrated in this paper is very similar to their outer whorls, on which the doubling of the umbilical bullae is also shown.

Occurrence.-Loc. UCLA. 3373, Oak Run valley, Member IV of the Redding area, Shasta County, northeast side of the Sacramento Valley. The type locality 
of Texanites kawasakii is on the lower course of the Santan, a tributary of the Naibuchi. This should be within the zone Mh6 (zone of Inoceramus naumanni) of the Miho group (MAtsumoto, 1942, p. 159, pls. 5, 8). Other examples came also from the Upper Urakawan (i.e. approximately Santonian) of Hokkaido and Sakhalin.

\section{Genus Submortoniceras Spath, 1921}

Type-species.-Submortoniceras woodsi Spath, 1921.

Generic diagnosis.- The whorl is moderately involute, increasing rapidly in height, compressed, and typically trapezoidal in section, with convergent flanks. The ribs are numerous, branching or intercalating at or above the umbilical margin, slightly flexuous or slightly prorsiradiate, and on the outer whorl much weakened. The tubercles are in five rows, among which those on the flanks are weakened and may finally disappear on the outer whorls, while the ventral (i.e. outer ventrolateral) and umbilical ones persist for a longer period. Even the ventral tubercles and keel may be smoothed in the latest growth-stage. The suture is considerably variable, following the general pattern of the Texanitinae.

Remarks.-I had an opportunity of studying the holotype of Submortoniceras woodsi which Dr. A. W. Crompton, the Director of the South African Museum, kindly let me borrow at Stanford University. Plaster casts of it are now at several institutions in the United States and at Kyushu University. I was also allowed to study the original types and WELLER's (1907) and also GARDNER's (1916) hypotypes of Ammonites delawarensis MoRTON, 1830 and Ammonites vanuxemi MORTON, 1830. Through the study of these types and the specimens from California and Japan, as well as from the survey of literature, I regard SpATH's (1921) proposal of Submortoniceras as reasonable despite the imperfect preservation of the holotype of $S$. woodsi.

The generic diagnosis given by CollignoN (1948, p. 64) is in principle acceptable, but the relationships with other genera must be discussed. From the available evidence I am inclined to search for the origin of Submortoniceras in Protexanites Matsumoto, 1955. The intermediate species, which occur in the Santonian of Japan and Sakhalin, are also related to certain species of Texanites Spath, 1932.

Delawarella Collignon, 1948, which has been established for Ammonites delawarensis MORTON, 1830, the type-species, and related species, is more intimately allied to Submortoniceras than to Menabites Collignon, 1948. Menabites (s.l.), including subgenera Menabites (s.s.), Bererella CollignoN, 1948, and Australiella Collignon, 1948, has a persistent trituberculate stage, in which the upper lateral tubercles are shifted towards the ventrolateral shoulder and are very prominent, as compared with the small, multiple, ventral tubercles (see Collignon, 1948, pl. 7 [1], figs. 8, 9). In Delawarella, as in Submortoniceras, the quadri- and then pentatuberculate stages begin early in growth, the lateral and even the ventrolateral tubercles are weakened on the outer whorl, 
the tubercles are approximately equidistant, and there is no such exaggeration of the tubercles as in Menabites. The difference between Submortoniceras and Delawarella is not great. On the average the former has a more compressed whorl and more strongly ornamented inner whorl than the latter; the upper lateral tubercle, which may be situated at the mid-flank, is distinctly strong on the inner whorl of Delawarella but weak in Submortoniceras. There is, however, considerable variability in both genera, and the distinction is in some cases only of a minor degree. Accordingly it is better to treat Delawarella as a subgenus of Submortoniceras. Incidentally Submortoniceras (s.s.) vanuxemi (MORTON) occurs in the same Merchantville clay of New Jersey as S. (Delawarella) delawarense (MORTON), according to the reliable information given by the late Dr. J. B. ReEside, Jr. (a letter dated December 4, 1957).

The Californian examples are all referred to Submortoniceras (s.s.). Butticeras ANDERSON, 1958 falls in the synonymy of Submortoniceras SPATH, 1921, because $B$. buttense ANDERSON, 1958, the type-species, is merely an example of Submortoniceras.

\author{
Submortoniceras chicoense (TRAsK) \\ Pl. 32, fig. 1a-d; Pl. 33, fig. 1a-c; Pl. 34, figs. 1a-c, 2a-d, 3a-c; \\ Pl. 35, figs. 1a-d, 2a, b
}

1856. Ammonites chicoensis Trask, Calif. Acad. Nat. Sci., Proc. vol.1, p.92, pl. 2, fig. 1, 1A.

1864. Ammonites chicoensis, GABB (pro parte), Palaeont. Calif., vol.1, p.68, pl. 13, fig. 17, 17a, 17b; pl. 14, fig. 17c.

? 1902. Schloenbachia chicoensis, ANDERSon (pro parte?), Proc. Calif. Acad. Sci., 3rd ser. vol. 2, no. 1, p. 116 (non ? pl. 1, figs. 21-22; pl. 2, fig. 23-25).

1902. Schloenbachia gabbi Anderson, Proc. Calif. Acad. Sci., 3rd ser. vol.2, no. 1, p. 117.

1902. Schloenbachia buttensis ANDERson, Proc. Calif. Acad. Sci., 3rd ser., vol. 2, no. 1, p. 118, pl. 4, figs. 110, 111.

1916. Schloenbachia templetoni HALL and Ambrose, Nautilus, vol. 30, p. 78.

1940. Ammonites chicoensis, TAFF, Hanna, and Cross, Bull. Geol. Soc. Amer., vol. 51, p. 1320, pl. 1, figs. 1, 2.

1943. Submortoniceras chicoense, Hanna and Hertlein, Calif. Dept. Nat. Res., Div. Mines, Bull. 118, p. 168, text-figs. 61-13, 14.

1958. Mortoniceras (Submortoniceras) chicoense, ANDERSON, Geol. Soc. Amer., Memoir 71, p. 269, pl. 60, figs. 1, 2.

1958. Mortoniceras (Submortoniceras) randalli ANDERson, Geol. Soc. Amer., Memoir 71, p. 269, pl. 46, fig. 1, 1a; pl. 50, figs. 2, 2a, 3.

1958. Mortoniceras (Submortoniceras) buttense, Anderson, Geol. Soc. Amer., Memoir 71, p. 270, pl. 33, fig. 5, 5a.

1958. Mortoniceras (Submortoniceras) pentzanum ANDERSON, Geol. Soc. Amer., Memoir 71, p. 270, pl. 51, figs. 1, 1a, 2, 2a.

? 1958. Mortoniceras (Submortoniceras) templetoni, Anderson, Geol. Soc. Amer., Memoir 71, p. 271, pl.60, fig. 4, 4a.

1958. Mortoniceras (Submortoniceras) gabbi, Anderson, Geol. Soc. Amer., Memoir, 71, p. 271.

Type.-Trask's original specimens (teste GABB, 1864, explanation of pl. 
14, fig. 17c) are missing. The illustrated specimen of Trask (1856, pl. 2, fig. 1, 1A) was regarded as lost by TAFF, HANNA, and Cross, who selected one of their collection from loc. CAS. 27838, Chico Creek, as a neotype (1940, p. 1320, pl. 1, figs. 1, 2) (CAS. 5785). This is an unofficial neotype, but is a well-preserved specimen sufficient to represent the specific characters. TRAsk's illustration seems to correspond well with the inner whorl of this specimen. Other specimens of Trask, if any, must have been lost together with the illustrated one. Thus, I agree with TAFF, HANNA, and CRoss in designating the specimen CAS. 5785 (1940, p. 1320, pl. 1, figs. 1, 2) as the neotype of Ammonites chicoensis Trask and this selection will be published in the Bulletin of Zoological Nomenclature.

Material.-In addition to the neotype, I have seen a larger number of specimens from the Chico area, and a few from another locality. The selected examples are as follows :

LSJU. 8631 (Pl. 33, fig. 1a-c) from loc. LSJU. 2609A (Coll. R. E. Cook); LSJU. 8630 (Pl. 32, fig. 1a-d), LSJU. 38426, LSJU. 8633 (Pl. 35, fig. 1a-d), LSJU. 8632 (Pi. 34, fig. 2a-d), LSJU. 8634 (Pl. 34, fig. 1a-c), LSJU. 8635 (Pl. 35, fig. 2a, b), LSJU. 8641 (Pl. 34, fig. 3a-c) (immature), etc. all from loc. LSJU. 2609 (Coll. R. E. CooK); several specimens from loc. LSJU. 2882 (Coll. R. E. CoOK) ; CAS. 5952 (HANNA and HERTLEIN, 1943, text-fig. 61-13, 14), hypotype of ANDERSON (1958, pl. 46, fig. 1, 1a; pl. 50, fig. 2, 2a; pl. 51, fig. 2, 2a) from loc. CAS. 27838 (Coll. TAFF, HaNnA, and CRoss); UCLA. 28818 from loc. UCLA. 3647 and other specimens from loc. UCLA. 3647, 3644, 3643, 3642, 3641, and 3631 (Coll. L. E. \& R. B. SAUL), the specimens now preserved at UCLA. from loc. CIT. 1041, 1040, etc. (Coll. W. P. Popenoe).

\begin{tabular}{|c|c|c|c|c|c|}
\hline Specimen (forma) & Diameter & Height & Breadth $(\mathrm{B} / \mathrm{H}) \quad \mathrm{U}$ & Umbilicus $(\%)$ & $\begin{array}{c}\text { Tubercles } \\
\text { umbilical/ } \\
\text { ventral }\end{array}$ \\
\hline CAS. $5785(\alpha-\beta)$ & 76.0 & 35.5 & $25.5 \quad(0.71)$ & $\begin{array}{ll}\text { r. } 18.2 & (24) \\
1.16 .9 & (21)\end{array}$ & $13 / 34$ \\
\hline LSJU. $8630(\alpha)$ & 85.3 & 39.4 & $29.4 \quad(0.74)$ & $22.4 \quad(26)$ & $13 / 28$ at diam. 94 \\
\hline LSJU. $8631(\beta)$ & 106.5 & 47.5 & 30.0 (deform.) & $26.8 \quad(25)$ & $19 / 43+5(?)$ \\
\hline $\begin{array}{l}\text { LSJU. } 8632 \\
\quad(\beta \text { or } \alpha-\beta)\end{array}$ & 62.0 & 28.8 & $21.3 \quad(0.74)$ & $14.8 \quad(24)$ & $15 / 34$ \\
\hline LSJU. $8633(\beta)$ & 58.5 & 28.7 & $20.1 \quad(0.70)$ & $13.0 \quad(22)$ & $13 / 34$ \\
\hline LSJU. $8634(\gamma)$ & 55.7 & 27.7 & $17.3 \quad(0.62)$ & $10.2 \quad(18)$ & $14 / 38(+)$ \\
\hline LSJU. $8635(\gamma)$ & 68.0 & 36.2 & $20.2 \quad(0.56)$ & $11.8 \quad(17)$ & $13 / 40(+)$ \\
\hline LSJU. $8636(\gamma)$ & 67.3 & 36.5 & $20.3 \quad(0.55)$ & $11.9 \quad(18)$ & - \\
\hline LSJU. $8637(\gamma)$ & 95.2 & 49.1 & $29.2 \quad(0.59)$ & $17.5 \quad(18)$ & - \\
\hline LSJU. $8638(\beta)$ & 40.0 & 19.6 & $13.8 \quad(0.69)$ & $9.5 \quad(24)$ & $13 / 25(?)+$ \\
\hline LSJU. $8639(\beta) \quad c$. & c. 113.0 & c. 54 & c. $28(+)$ (deform.) & .) $26.5 \quad(23)$ & $16 / 44(+2 ?)$ \\
\hline LSJU. $8640(\beta-\gamma)$ & 45.0 & 21.5 & $15.0 \quad(0.69)$ & $10.2 \quad(22)$ & $12 / 37(+)$ \\
\hline $\begin{array}{l}\text { LSJU. } 512 \\
\quad(\alpha \text { or } \beta ?)\end{array}$ & 174.0 & 75.5 & c. 20 (deform.) & c. $50.0 \quad(28)$ & - \\
\hline$\underset{(\text { ("randalli") }(\alpha)}{\text { CAS. }}$ & ) - & 38.0 & $29.0 \quad(0.76)$ & - & - \\
\hline$\underset{(\beta-\gamma)}{\operatorname{CAS} .(" g a b b i ")}$ & 72.5 & 35.2 & $20.2 \quad(0.59)$ & $14.6 \quad(20)$ & $13 / 26(+)$ \\
\hline CAS. $1125(\gamma)$ & 89.0 & 46.5 & $24.5 \quad(0.53)$ & $13.0 \quad(15)$ & $14 / 55(+)$ \\
\hline
\end{tabular}




$\begin{array}{llllllll}\begin{array}{l}\text { LSJU. (" randalli") } \\ (\beta)\end{array} & 44.0 & 30.5 & (0.69) & - & & - \\ \begin{array}{l}\text { UC. } 12096(\alpha-\beta, \\ \text { crushed) }\end{array} & 67.4 & 28.7 & 15.7 & (0.55) & 18.2 & (27) & 14 / 33 \\ \begin{array}{l}\text { UC. 12095 }(\gamma, \\ \text { crushed) }\end{array} & 101.0 & 54.4 & 21.7 & (0.40) & 13.5 & (13) & - \\ \begin{array}{l}\text { One from loc. } \\ \text { UC. A-1420 }(\gamma)\end{array} & 64.0 & 31.0 & c .17 .0 & (0.55) & 12.3 & (19) & 12 / 44 \\ \text { CAS. 5952 }(\alpha) & 59.0 & 27.5 & 23.3 & (0.85) & 16.7 & (28) & 13 / 14 \times 2 \\ \text { LSJU. 8641 }(\alpha) & 27.0 & 10.8 & 10.8 & (1.0) & 8.8 & (32) & 12 / 25+2(?) \\ \text { UCLA. 28818 }(\gamma) & 86.5(+) & 44.5 & 27.4 & (0.62) & 14.0 & (16) & 12 / 51\end{array}$

Diagnosis.-The shell is normally of moderate size, relatively involute, and fairly narrowly umbilicate, with rapid increase of whorl-height. The whorl is much higher than broad, and trapezoidal in cross section, being broader in the dorsal part than in the ventral part, with the maximum breadth at about a quarter of the height of the whorl. The side is slightly convex; the umbilical wall is steep and sometimes overhanging; the umbilical shoulder is rather angular and ornamented with prominent tubercles, which are pointed and tend to project laterally or slightly inward.

The side of the whorl is ornamented with numerous ribs of unequal length, which are somewhat flexuous on the inner whorls, but less so and more or less prorsiradiate on the outer whorl. The primary ribs arise from the umbilical tubercles, while the secondaries are branched or inserted at or near the umbilical tubercles and sometimes also at or near one of the lateral tubercles. There are three rows of weak lateral tubercles on the ribs, of which the inner lateral tubercles are relatively more prominent than others and are fairly distant from the umbilical tubercles. The outermost lateral tubercles may be called inner or lower ventrolateral, but are so suppressed that they scarcely form peripheral angulation. Only a slight bend of ribs is discernible at that position. On some individuals the lateral tubercles, especially the outer ones, are so weak that they are obsolete or almost disappear.

The ribs end at the distinct ventral (or "outer ventrolateral") tubercles, which are clavate and form distinct, angular edges of a narrow venter. The siphonal keel is moderately strong and slightly lower than the top of ventral tubercles. The umbilical and ventral tubercles are much stronger and more persistent than the lateral tubercles, but even the ventral ones are sometimes weakened on the body whorl. Because of bifurcation and intercalation of the ribs, the ventral tubercles are nearly twice to three times as numerous as the umbilical ones.

The suture is of general texanitine type. The external saddle is broad and asymmetrically bifid; the first lateral lobe (L) is moderately broad and deep; the lateral saddle and the second lateral lobe (U) are much smaller than, but rather similar in pattern to, the external saddle and the first lateral lobes; the auxiliaries are minute.

Variation.-The species is remarkably variable in the characters of the shell, such as involution of whorls, breadth of the umbilicus, proportion between breadth and height of the whorl, coarseness and density of the ribs, strength of the 
ornament, details of the sutures and so on. The figures in the measurements may be of some aid in understanding the situation.

For descriptive purpose, the variation can be grouped into three, which are called here for the sake of convenience forma $a, \beta$, and $\gamma$. However, there is perfect gradation among them and they occur in the same bed or even in the same nodule of the same locality. Examples of the three groups are concisely mentioned as follows:

(1) forma a, represented by the specimens LSJU. 8630 (Pl. 32, fig. 1a-d), CAS. 5952 (HANNA and Hertlein, 1943, text-fig. 61-13, 14 on p. 169), CAS. 5785 (TAFF et al, 1940, pl. 1, figs. 1, 2), and the one from loc. UCLA. 3643.This is relatively less compressed ( $b / h$ being about 7-8/10), and has coarse and strong ribs and distinct tubercles even on the sides. The ventral tubercles are nearly twice as numerous as the umbilical ones.

(2) forma $\beta$, represented by the specimens LSJU. 8631 (Pl. 33, fig. 1a-c), LSJU. 8632 (Pl. 34, fig. 2a-d), LSJU. 8633 (Pl. 35, fig. 1a-d) and LSJU. 8638.This is rather intermediate in every respect between $a$ and $\gamma$; the umbilicus is about $25-22$ per cent of the diameter; $b / h$ about $7 / 10$; the ribs are moderately dense and weak, the lateral tubercles are weak but mostly discernible, the ventral tubercles are about two and a half times as numerous as the umbilical ones.

(3) forma $\gamma$, represented by the specimens LSJU. 8634 (Pl. 34, fig. 1a-c), LSJU. 8635 (PI. 35, fig. 2a, b), LSJU. 8636, etc.-This is much involute, narrowly umbilicate (17-18\%), much compressed (b/h: 5.5-6/10), densely and weakly ribbed, and its lateral tubercles are very faint or almost lost. The ventral tubercles are nearly three times as numerous as the umbilical ones. The saddles and lobes of this group are relatively trigonal in general outline with broad base and rapid narrowing towards the apex, while those of other two groups are rather subrectangular in general outline with gradual decrease of their breadth from the bottom of the apex. However, the triangular shape of sutural elements is sometimes found in the latter and vice versa.

Remarks.-Since the original type specimen (or specimens?) of Ammonites chicoensis TrASK (1856, p. 92, pl. 2) was (or were) regarded as having been lost by fire in 1906, TAFF, HANNA, and Cross (1940, p. 1320, pl. 1, figs. 1, 2) designated the neotype. They did not, however, give a revised description of the specific characters nor extent of variation. That unofficial neotype, CAS. 5785, from loc. 27838 (C. A. S.), Chico Creek, occupies just an intermediate position between $a$ and $\beta$ of the above description.

ANDERSON (1958), in his recently published memoir, has established several new species for the specimens from the same loc. 27838 (C. A. S.) and other nearby localities in the Chico-Pentz area, in addition to the reillustration (ANDERsoN, 1958, p. 269, pl. 60, figs. 1, 2) of the neotype of TAFF et al. The holotype of Mortoniceras (Submortoniceras) randalli ANDERSON (1958, p. 269, pl. 50, fig. 2, 2a), from loc. CAS. 27838, is one of the examples of forma a and that of Mortoniceras (Submortoniceras) pentzanum ANDERSON (1958, p. 270, pl. 51, fig. 
1, 1a), again from loc. CAS. 27838, is a good example of forma $\gamma$. Since the examples of forma $a, \beta, \gamma$ occur together and are morphologically gradational, I regard them as one and the same species, Submortoniceras chicoense (TRASK), of great variation. If this view is warrantable, ANDERson's new specific names randalli and pentzanum will fall in the synonymy of chicoense.

However, if further statistical study based on accurate subzonal collection should make it clear that the three forms occur most abundantly at different levels, they should be separated subspecifically. In such a case, randalli and pentzanum could be used as subspecific names under chicoense. So far as the available evidence is concerned, the coarsely and relatively strongly ornamented examples (forma a) seem to be sparse as compared with weakly and densely ornamented ones (forma $\beta$ and $\gamma$ ) throughout the thickness of the "zone of Submortoniceras chicoense" of the Chico formation (s.s.) in the Chico area, but the former are always associated with the later.

Strange to say, Submortoniceras chicoense (TRASK) has not been found outside the Chico area, except at one locality in the Bay area, in spite of its abundance in the Chico area. From that exceptional locality, Redmont Cut, east of Altamont in Alameda County, came two specimens of relatively well ornamented form (a). One of them (LSJU. Coll.) was illustrated as Mortoniceras (Submortoniceras) randalli ANDERSON (1958, pl. 50, fig. 3), and the other (LSJU. 512) was described as Schloenbachia templetoni HALL and Ambrose (1916, p. 78, without illustration; ANDERSON, 1958, p. 271, pl.60, fig. 4, 4a). The former is fragmentary but the preserved part shows the character of forma $\beta$. The latter is unusually large and slightly evolute, but otherwise almost indistinguishable from forma a, although the crushed condition makes it difficult for us to measure accurately the proportion of height and breadth and width of umbilicus. The large size may not be unnatural, since some of the specimens from the Chico area, in which body whorls are not completely preserved, reach about $120 \mathrm{~mm}$. The two specimens from Alameda County are thus most reasonably referable to $S$. chicoense (TRASK).

It is interesting to find similarity between $S$. chicoense (TRASK) from California and some of the numerous species of the same genus from the Lower to Middle Campanian of Madagascar. Judging from the descriptions and illustrations of CoLLIGNON (1932, 1948), the Madagascar species seem to be very variable. Whether a number of species from the same bed of the same area, for instance, seven from Lower Campanian "niveau 2 de Berere", of Madagascar are all justified or can be grouped into a smaller number of species is a question, which I cannot discuss here without seeing their occurrence and actual specimens. Anyhow, the examples which have been described and illustrated under the name of $S$. piveteaui CollignoN (1948, p. 102, pl. 7 [1], fig. 6, 6a, 6b; pl. 19 [13], fig. 2, 2a), from "niveau 5 de Berere", basal Middle Campanian of Madagascar, closely resemble forma a of S. chicoense (TRASK) in many respects. Even in the immature stage there is close similarity, as understood by comparison of the specimen LSJU. 8641 (Pl. 34, fig. 3a-c) with that illustrated 
by Collignon (1948, pl. 7 [1], fig. 6, 6a, 6b). The only difference may be slightly broader space between the ventral tubercles and more massive and broad saddles of the suture in the Madagascar examples than in the Californian ones. The specimen illustrated as $S$. imlayi Collignon (1948, p. 101, pl. 16, fig. 3, 3a), from "niveau 2 Ouest Ankilizato", Middle Campanian of Madagascar, is similar to forma $\beta$ of $S$. chicoense (TRASK) of California in slight convexity of flanks, proportion of breadth and height, fairly narrow umbilicus, density and curvature of ribs, weakness of tubercles on the side. Unfortunately only a single, somewhat weathered, example of $S$. imlayi CoLlignoN has been illustrated. Therefore I hesitate to conclude the identity between the two forms. S. angusteumbilicatum Collignon (1948, p. 105, pl. 16, figs. 1, 1a, 2, 2a), from "niveau 5 de Berere", basal Middle Campanian of Madagascar, and S. spathi CollignoN (1948, p. 106, pl. 20 [14], fig. 1, 1a), from "niveaux 5, 6', 7 de Berere", Middle Campanian of Madagascar, are fairly similar to forma $\gamma$ of $S$. chicoense (TRASK) of California in much compressed whorls, relatively large involution, narrow umbilicus, dense and weak ribbing, obsolete outer two rows of tubercles on the side, and pattern of sutures. S. spathi CoLlignoN has nearly parallel flanks, while the Californian example still keeps general trapezoidal whorl-section. S. angusteumbilicatum CoLlignoN has rounded venter, with much weakening of external tubercles and keel, in the late growth-stage, while the external tubercles and keel persist better in the Californian form.

Although some similarity may be found between S. chicoensis (TRASK) and certain species from the Lower Campanian of Madagascar, e.g. S. tenuicostulatum Collignon (1948, p. 96, pl. 19 [13], fig. 1, 1a, 1b) and S. condamyi Collignon (1932, p. 36, pl. 5, fig. 3, 3a, 3b; text-fig. 20 ; 1948, p. 100, pl. 18 [12], fig. 2, 2a, $2 b ;$ pl. 15), these Lower Campanian species are less involute, more widely umbilicate and broader than S. chicoense (TRASK) of California and its allied species from the Middle Campanian of Madagascar.

In connection with the variability of $S$. chicoense (TRASK), the specimens which were described by GABB (1864) and ANDERSON (1902) ought to be mentioned. However, some of the specimens of these older dates are missing or thought to have been destroyed, so I cannot give full remarks on them. I could not find any specimens that fit GABB's illustration of Ammonites chicoensis (GABB, 1864, p. 68, pl. 13, fig. 17, 17a, 17b; pl. 14, fig. 17c). One of the originals of Schloenbachia gabbi ANDERSON (1902, p. 117) is preserved in the Museum of Invertebrate Paleontology, UC. 12095. This is crushed but it almost certainly falls within the extent of variation of $S$. chicoense (TRASK), being intermediate between form $a$ a and $\beta$ of the above description. GABB (1864, p. 69) reported, in addition to the specimens of Chico-Pentz area, a specimen from "Rancho de San Luis Gonzaga, Pacheco Pass, Merced County (Division A)" and also some from Siskiyou Mountains, Siskiyou County. I have not seen those specimens, so no comments can be given. The single specimen, UC. 12096, which was described as Schloenbachia buttense ANDERSON (1902, p. 118, pl. 4, figs. 110, 111), from the locality of "Pence's ranch, Butte County", is again secondarily com- 
pressed, but shows the ornaments of forma $a$ in the above description. Accordingly ANDERSON's later name randalli could well be identical with his earlier name buttense. Anyhow, both of them are include in S. chicoense (Trask).

Associated with a large number of specimens of Submortoniceras chicoense (TRASK) in the Chico-Pentz area, occurs specimens of peculiar character. They were called Butticeras studleyi ANDERson (1958, p. 272, pl. 51, figs. 3, 4, 4a) and Butticeras buttense ANDERSON (1958, p. 272, pl. 53, figs. 3, 3a, 3b, 4). They are small, less than $45 \mathrm{~mm}$. in shell diameter, but have already lost their tuberculation and keel on the body whorl of that small size (in studleyi), or even earlier than that (in buttense). The outer whorl has, accordingly, narrowly rounded, smoothish venter. The septate part, however, has clavate ventral tubercles and the keel. The shell is relatively evolute and flattened; the umbilicus is shallow and fairly wide, but sometimes fairly narrow; the umbilical tubercles are small, distant and not numerous (6 or 7 per whorl); the lateral ribs are weak; the suture is apprently simple, with shallow and minor incisions.

These peculiar examples might be regarded as an extreme variant of $S$. chicoense (TRASK). This might be true, but in our present knowledge, I hesitate to conclude so, because it deviate too far from the typical form of $S$. chicoense (TRASK) and no transitional specimens have been found. Anyhow they are referable to Submortoniceras, because many species of Submortoniceras, including the type species, S. woodsi (SPATH) and S. angusteumbilicatum Collignon, have a distinctive tendency to weakening of the ornament on the outer whorl. Thus the generic name Butticeras ANDERson, 1958 falls in the synonymy of Submortoniceras SPATH, 1921.

Occurrence.-Locs. CAS. 27838, LSJU. 2609, 2882; UC. A-4654, A-1420; UCLA. 3637, 3641, 3642, 3643, 3644, 3645, 3647 ; CIT. 1040; SOC. K-179, K-180, K-199; TM. 1014 [=LSJU. 3297], TM. 1015 [=LSJU. 3295], all in Chico Creek, upper half of the Chico formation in its type area, always associated with Baculites chicoensis TrASK. LSJU. 2882, CAS. 1125, CIT. "P36-33", Butte Creek; LSJU. $3293 \div$ CAS. $1125 \div$ TM. 1000, near Pentz (Pence), equivalent of the upper part of the type Chico formation (associated with Baculites chicoensis). The species occurs abundantly in the type Chico area of east side Sacramento Valley, but is very rare in other areas. The only locality which I have confirmed outside the Chico area is loc. LSJU. 3356, Redmont Cut, along the Western Pacific Railroad, east of Altamont, Alameda County, Bay area. Here the specimens are embedded in the shale in crushed condition and associated with Baculites chicoensis Trask.

Subfamily Lenticeratinae HYATT, 1900

Genus Pseudoschloenbachia SPATH, 1921

Type-species.-Pseudoschloenbachia umbulazi (BAILY).

Generic diagnosis.-See WrIGHT in MOORE [Editor], 1957, p. L436.

Remarks.-The systematic position of Pseudoschloenbachia is still question- 
able. As this is not the place to discuss it, I follow WRIGHT's temporary scheme.

Pseudoschloenbachia sp. aff. P. boulei (BASSE)

Pl. 35, fig. 3a, b; Pl. 36, fig. 2a, b; Text-fig. 69

Compare.-

1931. Schloenbachia (Muniericeras) boulei BAsse, Mongr. Paleont. Crét. Prov. Maintirano, Madagascar, p. 42, pl. 5, fig. 4; pl.13, fig. 6a, b.

1932. Schloenbachia (Muniericeras) boulei, Collignon, Ann. Paléont. vol.21, p. 31 , pl. 4, fig. 2, 2a, text-fig. 18.

Material.-Only five specimens are before me, UC. 31503 (Pl. 36, fig. 2a, b; Text-fig. 69) and another from loc. SOC. K-229 (Coll. M. V. KIRK), two from loc. SOC. K-230A (Coll. M. V. KIRK), and UCLA. 28845 (Pl. 35, fig. 3a, b) from loc. UCLA. 3790 (Coll. W. P. Popenoe), all being more or less imperfectly preserved.

Measurements.Specimen

\begin{tabular}{|c|c|c|c|}
\hline Diameter & Height & Breadth $(\mathrm{B} / \mathrm{H})$ & Umbilicus ( $\%$ ) \\
\hline 72.5 & 40.0 & $(0.52)$ & $11.3 \quad(16)$ \\
\hline 72 . & 36.0 & - & $12.4 \quad(17)$ \\
\hline c. 95 (estim.) & 49 (est.) & - & 14.0 \\
\hline 119 & 65 & 32 & (18) \\
\hline 75 & 37.5 & $18.7(0.50)$ & $9.7 \quad(13$ \\
\hline
\end{tabular}

UC. 31503

One fron $\mathrm{K}-230 \mathrm{~A}$

UCLA. 28845

CoLlignon (1932)

37.5

$18.7(0.50)$

$9.7 \quad(13)$

P. brannani UsHER (1952) 75

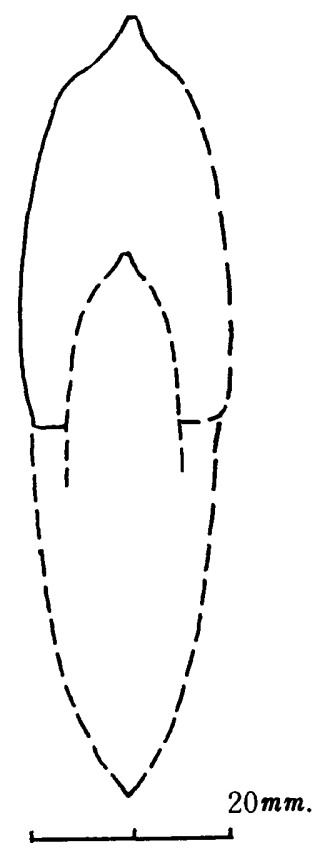

Fig. 69. Pseudoschloenbachia sp. aff. P. boulei (BASSE). Diagrammatic outline of the frontal view. UC. 31503, from loc. SOC. K-229, Hooten Gulch, upper part of Member V in the Redding area, Shasta County. See Pl. 36, fig. $2 a, b$ for other views. 
Description.-The best preserved specimen (Pl. 36, fig. 1a, b) has a diameter of about $80 \mathrm{~mm}$., in which the body whorl of about a half volution is preserved. From the position of the last suture on another, half preserved, specimen ( $\mathrm{Pl}$. 35, fig. 1a, b), its maximum diameter is estimated at about $95 \mathrm{~mm}$.

The shell is involute and fairly narrowly umbilicate. The whorl is much compressed, being nearly twice as broad as high in the relatively well preserved specimen. Other, probably secondarily deformed, specimens have apparently more compressed whorls. The flanks are only slightly convex and gradually convergent; the umbilical shoulder is subangular and the wall is low but steep, being slightly concave; the venter is fastigate and has a high keel.

Small but distinct tubercles are developed at the umbilical shoulder. Their number per whorl is inconstant, for instance, 9 in a half whorl of an adult example, but 11 in a full whorl of the septate part of another specimen. From these umbilical tubercles spring usually two, but sometimes one, low, blunt ribs. On the septate whorl the ribs are falcoid or even falcate, with a slight node-like elevation at the bend of the mid-flank and another blunt ventrolateral tubercle at their ends. The ribs are separated by wider interspaces. On the body whorl the ribs are much weakened, only discernible as fait, broad undulations on a portion of the flank. They are usually single and prorsiradiate and show gentle flexuosity on the upper part, being thus less falcoid than on the septate whorl. The ventrolateral tubercles become extremely faint and finally disappear on the adult body whorl. In addition to the major undulations, fine but rather irregular riblets are sometimes developed and also very fine lirae can be discernible in parallel to the major undulations.

The suture is similar to that of Pseudoschloenbachia umbulazi (BAILEY) (see SPATH, 1921, p. 241, text-fig. B) in general pattern, but the elements are relatively narrow.

Remarks.-In shell-form, ornament, and suture the Californian specimens here dealt with are undoubtedly referable to the genus Pseudoschloenbachia. They may represent a new species, but the material is not enough to erect it. The closest ally among the hitherto described species is Psudoschloenbachia boulei (BASSE) (1931), p. 42, pl. 5, fig. 4; pl. 13, fig. 6a, b) (CollignoN, 1932, p. 31, pl. 4, fig. 2, 2a, text-fig. 18) from the Lower Campanian of Madagascar. That Madagascar species has more regular, numerous riblets on the body whorl and broader saddles than the Californian form. I do not know, however, the real range of variation of $P$. boulei (BASSE).

Pseudoschloenbachia brannani Usfer (1952, p. 92, pl. 34, figs. 3, 4; pl. 31, fig. 25), from the Haslam formation of the Nanaimo group in Vancouver Island, may be another allied species. It has on the outer whorl numerous fine ribs which are more strongly falcoid than in $P$. boulei (BASSE). The ornament of its inner whorl is not known. Also its suture differs considerably from that of the Californian and Madagascar species in that the first lateral lobe is extremely broad and deep as compared with other lobes.

Occurrence.-Locs. SOC. K-229, K-230A, and UCLA. 3790, all in a limited 
portion, Hooten Gulch and its neighborhood, upper part of the Member V of POPENOE in the Redding area. This may be either Upper Santonian or Lowest Campanian.

The occurrence of P. brannani USHER in Vancouver Island is also infrequent. In Japan there is no well confirmed example of Pseudoschloenbachia, but the rare species which was described as "Pseudobarroisiceras nagaoi SHIMizu" (1932, p. 3, pl. 1 , figs. $1,2,4,5,6,7,8$ ) is, in my opinion, possibly the young whorl of a species of Pseudoschloenbachia, which is close to, if not identical with, $P$. besairiei Collignon (1932, p. 34, pl. 4, fig. 5, 5a, 5b). The locality of the Japanese specimens, lower course of the Wakkawen, a tributary of the Abeshinai, should be assigned to Upper Santonian or Lower Campanian, instead of Coniacian (see Matsumoto, 1942, maps of pls. 10, 12).

Family Placenticeratidae НYATT, 1900

Metaplacenticeras SPATH, 1926 is represented by a large number of specimens in California. This is a strong contrast to the abundant occurrence of Placenticeras MEEK, 1870 in the Western Interior province.

Four species of Metaplacenticeras have been established: $M$. pacificum (SмiтH) (1900, p. 207, pls. 26-28; ANDERSON, 1902, p. 79, pl. 8, figs. 162-164; pl. 9 , fig. 180 ; 1958, p. 254, pl. 37, figs. 1, 2, 3, 4, 4a), M. californicum (ANDERsoN) (1902, p. 78 , pl. 8, figs. $173-177 ; 1958$, p. 254, pl. 36, fig. 1), M. sanctaemonicae (WARING) (1917, p. 70, pl. 9, figs. 20, 21; ANDERSON, 1958, p. 255), and $M$. (?) bowersi ANDERSON (1958, p. 255, pl. 70, figs. 3, 4, 4a) [=Acanthoceras compressum ANDERson (1902, p. 107, pl. 9, fig. 187)].

On looking at numerous specimens I am inclined to admit a great variation of the species of Metaplacenticeras. There seems to be, for instance, gradation from the finely ribbed, much compressed form to the coarsely ornamented, less compressed one. The situation seems to be similar to that observed in $S u b$ mortoniceras chicoense (TRASK). The relationships between $M$. pacificum, $M$. californicum and $M$. sanctaemonicae should be carefully studied. Unfortunately I had not enough time for doing detailed measurements. As the original types of Placenticeras pacificum SMITH, 1900 and Placenticeras californicum ANDERsoN, 1902 were lost, a necessary procedure should be taken for designating and validating the neotype. In the present paper I have to omit a revised description.

In connection with the great variability of Metaplacenticeras the relationship of Metaplacenticeras subtilistriatum (JIMBo) (1894, p. 171 [25], pl. 17 [1], fig. 1) (MAтsuмото, 1953, p. 140, pl. 13, figs. 1-4, text-figs. 1-9), from Japan, with the American species should be restudied. So far as the available material is concerned, the Japanese species resembles $M$. pacificum in the immature stage, but has considerably broad, falcate ribs on the adult whorl. The ventrolateral clavi are much weakened and finally smoothed on the body whorl of $M$. subtilistriatum. There may be, however, a variation in the Japanese species, so a careful comparison based on further collecting is needed 
for a final conclusion. Anyhow I am now inclined to suppress subgenus Paraplacenticeras, because it is taxonomically unnecessary and because the distinction is not more than specific.

Another question concerns the geological occurrence of Metaplacenticeras. ANDERSON (1902, p. 79) recorded the stratigraphic positions of $M$. pacificum and $M$. californicum as the Lower Chico and later (1958, p. 254) referred them to the Coniacian. This does not seem to be based on sound grounds and is not in harmony with the results of reliable stratigraphic work, such as WARING (1917), Popenoe (1942), and Peck, Imlay, and Popenoe (1956). My conclusion from all the available evidence is that Metaplacenticeras occurs in the upper part of the Campanian in both Japan and California.

The localities and stratigraphic positions from which I identify Metaplacenticeras pacificum (SMITH) are as follows:

Loc. USGS. Mes. loc. 25218, in Member V of the Hornbrook formation, on the south side of the Klamath River, Siskiyou County, where Desmophyllites diphylloides (FoRBES) and Pachydiscus cf. subcompressus MATSUmoto are associated (Coll. PeCK, Imlay, \& Popenoe) ; loc. SOC. K-235, west of Hornbrook, probably Member $\mathrm{V}$ of the Hornbrook formation, in which Pachydiscus (s.s.) sp. and Anapachydiscus deccannensis (STOLICZKA) are associated (Coll. M. V. KIRK) ; loc. CAS. 444B, in a calcareous sandstone about $1 / 2$ mile south of Hornbrook, Siskiyou County

Locs. LSJU. 2709 (Coll. W. E. KennetT \& Stanley McCoy), SOC. K-241 (Coll. M. V. KIRK), CAS. 1467, and CAS. 1467A (Coll. RAMBKE), all on Enos Canyon, limestones in a shaly unit in the higher part of the Cretaceous sequence in Capay Quadrangle, Yolo County. Among the associated species there are Neophylloceras ramosum (MEEK), Desmophyllites diphylloides (FoRBES), Gaudryceras cf. denmanense WHITEAVES, Pseudoxybeloceras cf. lineatum (GABB), and Inoceramus subundatus MEEK

Locs. LSJU. 1840 (Coll. J. P. Smith), LSJU. 2732 (Coll. L. W. FunKHOUSER), LSJU. 2734 (Coll. L. W. FUNKhouSER), and CAS. 31245 (Coll. McCoy), all on Arroyo del Valle, Tesla County, where Baculites sp. aff. $B$. anceps LAMARCK and $B$. inornatus MEEK, among others, are identified Locs. CIT. 86, CIT. 974, CIT. 975, CIT. 976, CIT. 977 (Coll. W. P. PopenoE) and LSJU. 3349, all in Pleasants sandstone in the Santa Ana Mountains, Orange County; localities along Silverado Truck Trail in the Pleasants sandstone member, Santa Ana Mountains (Coll. T. Matsumoto); loc. UCLA. 2415, an isolated locality of the Cretaceous sandstone in El Toro Quadrangle, Santa Ana Mountains, Orange County (Coll. L. E. SAUL)

Locs. CIT. 54 (Coll. H. W. Hoots \& W. P. WoodRING), in a sandstone next to the highest member of the Cretaceous sequence in the Santa Monica Mountains, Los Angeles County (see PoPenoE, 1942, p. 176)

Locs. CIT. 1154, CIT. 1156, and CIT. 1159 (Coll. Robt Durbin, H. L. \& W. P. POPENOE) and also CIT. 1537, in a calcareous sandstone near the 
base of the Cretaceous sequence in Simi Hills, Los Angeles and Ventura Counties

The relatively strongly ornamented forms, which may be called $M$. californicum and $M$. sactaemonicae, are almost always associated with the typical examples of $M$. pacificum.

In Japan M. subtilistriatum occurs in the Lower Hetonaian (approximately Campanian), as I previously described (MAтsumoto, 1953, p. 140). The type locality is in a sandstone unit, probably equivalent of the Hakobuchi group, which in this general area of the Abeshinai Valley, Hokkaido, overlies the prolific part of the zone of Inoceramus schmidti-Canadoceras kossmati. Therefore the species can be regarded as indicating a fairly higher part of the Campanian. From the available evidence the same statement is applicable for $M$. pacificum in California, although it may have a certain extent of stratigraphic range. In connection with this the species from the Turonian of Madagascar (CoLlignoN, 1936) are questionable.

I have noticed one more doubtful record of Metaplacenticeras in California. That is represented by a specimen now preserved at Harvard University. MCZ. 2074, labelled as "Ammonites chicoensis TRASK, Chico Creek, California". It cannot be identified with Submortoniceras chicoense but is a relatively strongly ornamented example of Metaplacenticeras, which may be called $M$. californicum. In fact that specimen has another label written as "Placenticeras californicum ANDERSON (MS)". Its rock matrix is a very fine, calcareous siltstone, unlike the calcareous sandstones of the usual Chico Creek localities. I have no other reliable information about the occurrence of Metaplacenticeras in the Chico Creek area. So far as I know, the Cretaceous sequence exposed along the Chico Creek does not range up so high as to reach the Upper Campanian zone of M. pacificum.

Hoplitoplacenticeras vancouverense (MEEK) (1862, p. 317; 1876, p. 370, pl. 6, fig. 1, 1a-c) occurs in the Upper Cretaceous of Sucia Islands (see UsHer, 1952 , p. 93 , pl. 25 , figs. 1,2 ; pl. 31 , figs. 21,22 ). I have seen some examples in the collections of USGS. and UCLA. (with a number CIT. 1400). They are again from Sucia Island. The assemblage of species indicates the Campanian age. Despite the world-wide distribution of Hoplitoplacenticeras, no representatives have been found in the Upper Cretaceous of California.

Family Tetragonitidae HYATT, 1900

Subfamily Gaudryceratinae SPATH, 1927

In the Upper Cretaceous of California and adjacent areas I have recognized representatives of the genera, Anagaudryceras, Gaudryceras, Vertebrites, and Zelandites. Their occurrence is rather sporadic, but the species are identical with, or very closely allied to, the already described ones of the Indo-Japanese provinces. 


\section{Genus Anagaudryceras SHImizu, 1934}

Type-species.-Ammonites sacya ForBes, 1846.

Synonym.-Paragaudryceras SHIMIZU, 1934.

Generic diagnosis.-See MAtsumoto, 1942b (p. 669) and WRIGHT and Matsumoto, 1954, (p. 113).

Remarks.-Inconsistency in SHIMIZU's two papers $(1934,1935)$ about the designation of the type-species of Anagaudryceras and confusion derived therefrom in the understanding of this genus have been pointed out by WRIGHT and MATSUMото (1954) and further explained by myself (1959a).

The occurrence of Anagaudryceras sacya (FORBES) has not yet been confirmed in the undoubted Cenomanian of California, although some comparable specimens are known. There are two other species of Anagaudryceras in the Senonian of California, which are described below.

\section{Anagaudryceras yamashitai (YABE)}

\section{Pl. 37, fig. 1a-d}

1903. Gaudryceras yamashitai YABE, Jour. Coll. Sci., Imp. Univ. Tokyo, vol. 18, art. 2, p. 38, pl. 4, fig. 7 .

Holotype.-The figured specimen of $\mathrm{YABE}$ (1903, pl. 4, fig. 7), by original designation, from Hokkaido, now preserved at the University of Tokyo, Cat. No. GT. I-201.

Material.-The Californian representative is a single specimen, GK. H7027 (Pl. 37, fig. 1a-d), from loc. TM. 11 $[=$ LSJU. 3319] (Coll. M. B. PAYNE \& T. MATSUMOTO).

\begin{tabular}{lllllll}
$\begin{array}{c}\text { Measurements.- } \\
\text { Specimen }\end{array}$ & Diameter & Height & \multicolumn{2}{c}{ Breadth (B/H) } & Umbilicus (\%) \\
Holotype (after YABE) & 88 & 44 & 33 & $(0.75)$ & 22 & $(22)$ \\
Another Japanese example & 71.0 & 34.2 & 28.0 & $(0.81)$ & 18.7 & $(26)$ \\
GK. H 7027 & 67.3 & 29.2 & 22.9 & $(0.78)$ & 19.7 & $(29)$ \\
Holotype of A. politis- & 89 & 33 & 28 & $(0.85)$ & 34 & $(38)$
\end{tabular}

Diagnosis.-The outer whorl is compressed and suboval in cross section; the flanks are flattened and only slightly convex, the venter is gently arched and rather narrow, the umbilical wall is steep, surrounded by a rounded shoulder.

The inner whorl is subrounded and less compressed than the outer. The involution is nearly a half.

The surface of the shell is almost smooth. The constrictions are very infrequent and faint. They are prorsiradiate and gently convex on the inner part of the flank, but gradually become to be rectiradiate on the outer part.

The suture is of the typical Gaudryceras pattern, resembling that of $G$. tenuiliratum YABE (see MATSUMOTо, 1942b, text-fig. 1).

Remarks.-The Californian specimen so well resembles the holotype and other Japanese examples of $A$. yamashitai (YABE) that specific identify is undoubted. 
The obscurity in the present species is that the character of the adult body whorl is not well known, as YABE has mentioned. A fragmentary body whorl, which is preserved in a recently collected specimen from Hokkaido, shows a narrow rib and otherwise firely laevigate surface. Therefore A. yamashitai may be similar in ornament to A. yokoyamai (YABE) (1903, p. 36, pl. 4, fig. 2; pl. 6, figs. 1a, b, 2a, b; pl. 7, fig. 6') (see Matsumoto, 1941, text-fig. 1c).

A. yamashitai is, however, distinguished from $A$. yokoyamai by its more compressed whorl and flattened flanks. In this respect it resembles A. politissimum (Kossmat) (1895, p. 128 [32], pl. 15 [1], fig. 7a-c; Collignon, 1956, p. 58, pl. 8, fig. 2, 2a, 2b), but it has distinctly narrower umbilicus and more rapid growth of whorls.

Occurrence.-Rare in both Japan and California. Loc. TM. 11 [=LSJU. 3319], in the lower part of the Upper Marlife formation of the Panoche group in the type Panoche Hills, west side of the San Joaquin Valley, where Baculites capensis WooDs occur abundantly.

In Japan the species occurs in the Upper Urakawan, probably Santonian. The type locality in Hokkaido is recorded as "Mukka-ushipe, a tributary of the Popets, Province of Iburi" in the text, but as "Sanushibe, Province of Iburi" in the explanation of plate.

\section{Anagaudryceras mikobokense CoLLIGNON}

Pl. 38, fig. 1a-c; Text-fig. 70

1909. Gaudryceras politissimum, KILIAN and ReBoul (non Kossmat), Wiss. Erg. Schwed. Südpolar Exp., 1901-1903, vol. 3, 6, p. 14, pl. 1, figs. 7, 8.

1938. Gaudryceras politissimum, Collignon, Ann. Géol. Serv. Mines, Madagascar, fasc. 9, p. 42, pl. 7, fig. 2, 2 a.

1956. Anagaudryceras mikobokense Collignon, Ann. Géol. Serv. Mines, Madagascar, fasc. 23, p. 59, pl. 8, fig. 1, 1a, $1 \mathrm{~b}$.

1958. Lytoceras (Gaudryceras) coalingense ANDERson (pro parte), Geol. Soc. Amer., Memoir 71, p. 184 (non pl.68, fig. 1).

1958. Lytoceras (Gaudryceras) aureum ANDERSon, Geol. Soc. Amer., Memoir 71, p. 184, pl. 71, fig. 1, 1a.

Holotype.-The specimen illustrated by CollignoN (1956, pl. 8, fig. 1, 1a, 1b), by original designation. Its catalogue number is indicated as $n^{\circ} 1936$ in the explanation of plate 8 , but as $n^{\circ} 1937$ in the text (p. 59).

Material.-Several Californian specimens are at my disposal. Three, of which one is illustrated as Text-fig. 70, from loc. UC. B-4149 (Coll. UC. Paleont. Class + Monterey Peninsula College), show the diagnostic features. The fourth is a specimen ( $\mathrm{Pl}$. 38, fig. 1a-c) (not the holotype), from loc. CAS. 2362, which was assigned to Lytoceras (Gaudryceras) coalingense ANDERSON (1958, p. 184). The fifth is the holotype of Lytoceras (Gaudryceras) aureum ANDERSon (1958, pl. 71, fig. 1, 1a), from loc. CAS. 29656 (Coll. Allan BenNison). It is imperfectly preserved but is probably referable to the present species. 
Measurements.-

\begin{tabular}{|c|c|c|c|c|c|c|}
\hline Specimen & Diameter & Height & Breadtl & $(\mathrm{B} / \mathrm{H})$ & \multicolumn{2}{|c|}{ Umbilicus $(\%)$} \\
\hline Holotype (after CoLLigNON) & 92 & 39 & 35 & $(0.9)$ & 35 & $(38)$ \\
\hline $\begin{array}{l}\text { One from loc. UC. B-4149 } \\
\text { (at the last septum) }\end{array}$ & - & 52.0 & 47.0 & $(0.90)$ & - & \\
\hline Another from $\quad \prime \prime$ & 105.0 & 43.0 & 38.7 & $(0.90)$ & 37.0 & $(35)$ \\
\hline$(1 / 2$ vol. earlier than the above) & ) - & 27.5 & 25.5 & $(0.93)$ & - & \\
\hline Another from & - & 45.0 & 41.0 & $(0.91)$ & - & \\
\hline "L. (G.) aureum" ANDERSON & 140 & 56 & 51 & $(0.9)$ & 46 & 3) \\
\hline
\end{tabular}

Diagnosis.-The full-grown shell is fairly large. The whorls are moderately overlapping, with an umbilicus of moderate width. The whorl is slightly higher than broad in the late growth-stage, broadly oval in cross section, broadest in the lower part, with convex flanks, a rounded venter, subrounded umbilical shoulder, and a nearly vertical umbilical wall.

The surface is nearly smooth, with only fine lirae on the test and infrequent constrictions. The adult whorl is provided with very distant, narrow, major ribs, which may correspond to the constrictions of the inner whorl. The lirae, the constrictions, and the major ribs are convex near the umbilical shoulder, but gradually become to be radiate, with a very slight flexuosity, on the main part of the flank.

The suture is of typical Gaudryceras pattern, quite resembling that of Anagaudryceras politissimum (Kossmat) (1895, pl. 15 [1], fig. 7c) .

Remarks.-The present species is allied to Anagaudryceras yokoyamai (YABE) (1903, p. 36, pl. 4, fig. 2; pl. 6, figs. 1a, b, 2a, b; pl. 7, fig. 6') in the whorl shape, the nearly smooth surface, and the distant narrow ribs of the adult whorl. The adult whorl of $A$. yokoyamai was unknown at the date of its description by YABE (1903), but there are several examples of it in subsequent collections (see Matsumoto, 1941, p. 20, text-fig. 1c). A. mikobokense is distinguished from $A$. yokoyamai by its wider umbilicus and its slight flexuo-

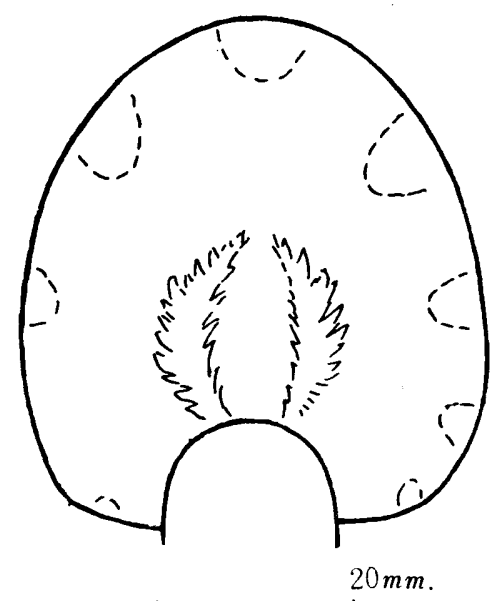

Fig. 70. Anagaudryceras mikobokense CoLLIGNON. Whorl-section of an example from loc. UC. B-4149, Ortigalita Peak Quadrangle, Merced County. 
sity of the major ribs. A. politissimum (Kossmat) (1895, p. 128 [32], pl. 15 [1], figs. 7a-c) is as widely umbilicate as the present species but has much more compressed whorls.

A. mikobokense CollignoN has been known in the Maestrichtian of Madagascar and in the Upper Senonian of the Antarctica. The existence of representatives in California is very interesting. Although ANDERsoN gave new specific names, the holotype of Lytoceras (Gaudryceras) aureum ANDERSON (1958, p. 184, pl. 71, fig. 1, 1a) and an unillustrated paratype of Lytoceras (Gaudryceras) coalingense ANDERSON (1958, p. 184) are indistinguishable from A. mikobokense. The actual specimen of his $L$. (G.) aureum is not so flattened as the figure (ANDERSON, 1958, pl. 71, fig. 1a) appears to show.

Occurrence.-Loc. UC. B-4149, in Ortigalita Peak Quadrangle, where this species is associated with Pachydiscus egertoni (ForBes), Gaudryceras (Vertebrites) kayei (FORBES), and Glyptoxoceras subcompressum (FORBES). Loc. CAS. 29656, close to the above locality, where Neophylloceras hetonaiense MATSUмото, among others, is also found. Loc. CAS. 2362, Los Gatos Creek, in Coalinga Quadrangle, where this species is associated with Damesites hetonaiensis fresnoensis (ANDERson), Pachydiscus ef. egertoni (FORBES), Gaudryceras (Vertebrites) kayei (FORBES), etc. These three localities can be referred to the relatively higher part of the Panoche group, west side of the San Joaquin Valley. The assemblage of species and the stratigraphic position suggest most probably the Lower Maestrichtian, but the horizon might possibly be the highest part of the Campanian.

\section{Genus Gaudryceras DE Grossouvre, 1894}

Type-species.-Ammonites mitis HAUER, 1866, designated by Boule, LEMOINE, and THEVENIN, 1906.

Synonymy.-Neogaudryceras SHImizu, 1934; Epigaudryceras SHIMizU, 1934; Hemigaudryceras SHImizu, 1934; Pseudogaudryceras SHImizu, 1934 (nom. nud.) (See Wright and Matsumoto, 1954, p. 112).

Diagnosis.-See Wright in MOORE [Editor], 1957, p. L200.

Remarks.-Discussion is necessary of the distinctness or otherwise of the subgroups in the synonymy. For instance, CollignoN (1956) still holds Neogaudryceras as a distinct genus. The Californian material is not sufficient for a full treatment of the question. My view depends rather on the prolific Japanese species which, I have not yet monographically described, so I will not give here too long remarks.

Gaudryceras tenuiliratum YABE, the type-species of Neogaudryceras SHImIZU, shows in a limited period of its middle growth-stage multiple branching of the riblets into very fine lirae on the ventral part. It has also polygyral and depressed whorls in the immature stage. These two characters evidently foreshadow Vertebrites, but they are not firmly stabilized in G. tenuiliratum. In other words, G. tenuiliratum still resembles $G$. mite and other typical ex- 
amples of Gaudryceras (s.s.) in general aspect. On the other hand, there are in Japan several mature shells of Vertebrites sp., probably $V$. kayei (ForBes), whose outer whorls are not depressed, not angulated at the shoulders, and thus do not deviate much from those of G. striatum (Јімво). G. striatum, in turn, is closely allied to G. tenuiliratum, as I have already mentioned (MATSUмото, 1941 [in Japanese], p. 23).

On the above grounds, I do not think it necessary to keep Neogaudryceras as a distinct genus, but instead, I am rather inclined to rank Vertebrites as a subgenus of Gaudryceras. The relationship of Vertebrites to Gaudryceras (s.s.) is closely parallel to that of Saghalinites to Tetragonites (s.s.).

Comparison of the species between the northern Pacific, Indian, African, and European provinces is another question to be studied. Certain species have received different names, although they seem to be closely allied or even identical. As YABE (1903, p. 14) has rightly pointed out, the specific distinction of Gaudryceras cannot be adequately done without carefully inspecting the characters at different growth-stages. The species of Gaudryceras in California are represented by a relatively small number of imperfectly preserved specimens. For precise identification more and better preserved specimens are needed. Under these circumstances I can give here only a preliminary note on some of the species.

\section{Subgenus Gaudryceras (s.s.) \\ Gaudryceras (s.s.) denseplicatum (Jімво)}

1894. Lytoceras denseplicatum Jiмвo, Pal. Abh., Bd.6 (N.F. 2), p. 182 [36], pl. 23 [7], fig. 1, 1a.

1894. Lytoceras sacya, Jiмвo (non Forbes), Pal. Abh., Bd. 6 (N. F. 2), p. 180 [34], pl. 22 [6], fig. 1, 1a.

1903. Gaudryceras denseplicatum, YABE, Jour. Coll. Sci., Imp. Univ. Tokyo, vol. 18, art. 2, p. 31.

1903. Gaudryceras tenuiliratum var. infrequens YABE, Jour. Coll. Sci., Imp. Univ. Tokyo, vol. 18, art. 2, p. 28, pl. 4, fig. 3a, b.

1941. Gaudryceras denseplicatum, MAтsumoto, Jour. Geol. Soc. Japan, p.22, text-fig. 2a.

1956. Neogaudryceras denseplicatum, CoLlignon, Ann. Géol. Serv. Mines, Madagascar, fasc. 23, p. 60, pl.9, fig. 1, 1a.

1958. Lytoceras (Gaudryceras) aff. L. tenuiliratum, ANDERSON (non YABE), Geol. Soc. Amer., Memoir 71, p. 183, pl. 40, fig. 1.

Holotype.-Јгмво's original specimen (1894, pl. 23 [7], fig. 1, 1a), from Hokkaido, now preserved at the University of Tokyo, Cat. No. GT. I-118.

Material.-The specimen described as Lytoceras (Gaudryceras) aff. $L$. tenuiliratum by ANDERSON (1958, p. 783, pl. 40, fig. 1), from loc. CIT. 1347 (Coll. W. P. Popenoe and W. A. Findlay).

Diagnosis.-The full-grown shell is fairly large. The whorl grows fairly rapidly, and overlaps considerably. It is suboval in section, being higher than broad in the later growth-stages, but as high as broad or even broader than 
high in the earlier stages; the venter is evenly arched, the flanks are moderately convex, the shoulders rounded, and the umbilical walls steep. The umbilicus is fairly narrow, especially in the late growth-stage.

The shell is ornamented with numerous, crowded subcostae, which diverge near the shoulders. There are periodic constrictions on the inner whorls, rather infrequent, except in the earliest growth-stage. The major ribs begin to develop sooner or later in the middle growth-stage, being at first relatively narrow and distant, looking like frequent constrictions. Then, on the adult whorl, they became strongly plicate, being separated by interspaces which are on the main part somewhat broader than, and finally nearly as broad as, the ribs themselves. The narrow subcostae cover the major ribs as well as the interspaces. The ribs and subcostae are flexuous on the flank, bending strongly forward near the umbilical shoulder, convex on the lower part of the flank, gently concave on the upper part, and gradually projected on the venter.

The suture is of typical Gaudryceras pattern, quite resembling that of G. tenuiliratum YABE (see Matsumoto, 1942b, text-fig. 1).

Remarks.-A typical example of the present species from California was referred to G. tenuiliratum YABE by ANDFRSON (1958, p. 183, pl. 40, fig. 1), but this is evidently due to misunderstanding of the Japanese species. The diagnosis given above, based on the Japanese material, applies to this Californian specimen as well as to the Madagascar specimens (CoLIIGNoN, 1956, p. 60, pl. 9, fig. 1, 1a).

The present species shows considerable variability as understood from the numerous specimens of Japan. In addition to the typical form defined above, there is another form, in which the major ribs are relatively narrow, separated by much wider interspaces, even on the adult whorl. In other words, the type of ribbing as seen in the short period of middle-growth stage in the typical form persists to the adult stage in this subgroup. The subgroup is represented by "Gaudryceras tenuiliratum var. intermedia" YABE (1903, p. 27, pl. 3, fig. 1a, b), which, however, is better attached to G. donseplicatum, because it is as narrowly umbilicate and as coarsely subcostae as the typical form of $G$. denseplicatum. Extremely fine lirae characteristically develop on the venter for a limited period in the immature stage of $G$. tenuiliratum, but they are not found in this "intermedia" subgroup. Relatively narrow and distant ribs are, however, characteristic of the adult whorl of G. tenuiliratum. In this respect the subgroup is rather transitional to that species, and can be classified as a subspecies, Gaudryceras denseplicatum intermedium YABE. YABE's illustrated specimen (YABE, 1903, pl. 3, fig. 1a, b) is here designated as the lectotype of this subspecies.

The Californian specimen under consideration is referred to $G$. denseplicatum denseplicatum. So is the specimen from Madagascar illustrated by Collignon (1956, pl. 9, fig. 1, 1a).

Another specimen from California, the holotype of Lytoceras (Gaudryceras) delvallense ANDERSON (1958, p. 183, pl. 41, fig. 4, 4a), may be related to $G$. 
denseplicatum intermedium, but is more evolute and, so far as the preserved part is concerned, it does not show the frequent major ribs. Therefore it is closely allied to, and possibly identical with, Gaudryceras varagurense Kossmat (1895, p. 122 [26], pl. 18 [4], fig. 2a-c; also Collignon, 1956, p. 56, pl. 5, fig. 6) from the Trichinopoly group of India and the Lower Senonian of Madagascar.

Occurrence.-As only a single specimen from California is at my disposal, I presume that $G$. denseplicatum is rare in the Upper Cretaceous of California. The locality is CIT. 1347, recorded as "the highest Cretaceous beds exposed on the Roaring River, Shasta County, northwest side of the Sacramento Valley" (information given by Dr. W. P. POPENOE), where Damesites damesi intermedius occurs.

In Japan and Sakhalin the species is very common but long ranging from the Turonian to the Lower Campanian. According to Collignon (1956, p. 61) it is restricted to the Coniacian in Madagascar.

\section{Gaudryceras (s.s.) cf. denmanense WhITEAVES Pl. 37, fig. 2a, b}

\section{Compare.-}

1879. Ammonites jukesii ?, Whiteaves (NON SharPe), Mesozoic Fossils, vol.1, pt. 2, p. 111, pl. 13, fig. 3, 3a, 3b.

1895. Lytoceras jukesii, WhiteAves, Trans. Roy. Soc. Canada, 2nd ser., vol. 1, sec. 4, p. 129, pl. 2, figs. 1, 2.

1901. Lytoceras (Gaudryceras) denmanense WhITEAVES, Ottawa Naturalist, vol. 15, p. 31.

1903. Gaudryceras denmanense, Whiteaves, Mesozoic Fossils, vol. 1, pt.5, p. 329.

1952. Gaudryceras denmanense, Usher, Geol. Surv. Canada, Bull. 21, p.59, pl. 4, figs. 1, 2.

? 1958. Lytoceras (Gaudryceras) alamedense, ANDERSON (non SMITH), Geol. Soc. Amer., Memoir 71, p. 182, pl. 41, fig. 5, 5a.

Lectotype.-GSC. No. 5854, reillustrated by UsHer (1952, pl. 4, fig. 1), from Denman Island, British Columbia, designated by USHeR (1952, p. 60).

Material.-Several Californian specimens are referable to this species. They are LSJU. 8580 (Pl. 37, fig. 2a, b), from loc. LSJU. 2880 (Coll. R. E. Cook), and others from loc. UCLA. 3633 (Coll. L. E. \& R. B. SAUL), UCLA. 3642 (Coll. L. E. \& R. B. SAUL), SOC. K-241 (Coll. M. V. KIRK ?), and CAS. 1343 (Coll. F. M. ANDERson). The last one was described as Lytoceras (Gaudryceras) alamedense ANDERSON (1958, p. 182, pl. 41, fig. 5, 5a).

I had an opportunity of looking at plaster casts of the lectotype and another illustrated specimen from British Columbia. A specimen from loc. CIT. 1398, Sucia Island (Coll. R. Durbin and W. P. Popenoe) has also been examined.

$\begin{array}{cccccc}\text { Measurements.- } & & & & \\ \text { Specimen } & \text { Diameter } & \text { Height } & \text { Breadth (B/H) } & \text { Umbilicus (\%) } \\ \text { Lectotype (after UsHeR) } & 103 & 41 & 34(0.8) & 36 \quad(35)\end{array}$




$\begin{array}{llllll}\text { GSC. 5800 (after USHER) } & 38 & 12 & 10 & (0.8) & 18(47) \\ \text { LSJU. 8580 } & 34 & 12 & 11(0.9) & 15(44) \\ \text { ANDERSON's alamedense } & 57 & 19 & 19 & (1.0) & 25 \text { (44) }\end{array}$

Descriptive remarks.-Gaudryceras denmanense WhITEAVEs most closely resembles G. tenuiliratum Y $\mathrm{ABE}$ (1903, p. 19, pl. 3, figs. 3, 4) [=Lytoceras sacya, YokоYAMA (non FoRBES), 1890, p. 178, pl. 18, figs. 12a, b, 13a, b]. On the adult whorl of the former, as can be clearly seen from UsHER's (1952, p. 59, pl. 4, figs. 1,2) description and illustration, there are characteristic major ribs. They are nearly as narrow and elevated as, but may be somewhat more frequent and less flexuous than, those of the adult shell of the latter. In G. tenuiliratum the fine, minor ribs, or "subcostae", cover the major ribs and the interspaces, but they are only occasionally found or are almost absent on the adult whorl of $G$. denmanense. In other words in $G$. denmanense the major ribs of the adult shell look as if they develop from the coarsened minor ribs.

Unfortunately the available specimens from California are all small and probably immature. Even in the immature stage, however, G. denmanense can be distinguished from $G$. tenuiliratum. The subcostae are multipartite near the shoulders and the very fine lirae densely cover the venter for a certain period in the immature stage of G. tenuiliratum. This character, which can be regarded as the Vertebrites type of ornamentation, does not occur in $G$. denmanense. In this respect the Californian specimens under consideration are referable to $G$. denmanense rather than to G. tenuiliratum.

The types of Lytoceras alamedense SмIтн (1898, p. 136, pl. 16, figs. 1-12; pl. 17, figs. 1-6; pl. 18), from JoRDAN ranch, Arroyo del Valle, are all very small and what was called by SMITH as adult example can hardly be regarded as truly adult. Therefore SMITH's species is very indefinite, despite his detailed description of the ontogenetic development. The specimen recently referred to L. alamedense by ANDERSON (1958, p. 182, pl. 41, fig. 5, 5a), from loc. CAS. 1343 , is well comparable with, and probably referable to $G$. denmanense Whiteaves, $G$. denmanense Whiteaves, 1901 could be, thus, a synonym of $G$. alamedense SмIтн, 1898. The available material is, however, insufficient for a decision.

Occurrence.-Locs. LSJU. 2880 and UCLA. 3633, lower part of the Chico formation, associated with Baculites capensis WooDs, Hauericeras (Gardeniceras) angustum, etc.; loc. UCLA. 3642, upper part of the Chico formation, associated with Submortoniceras chicoense, in the type section of Chico Creek, Butte County, east side of the Sacramento Valley. Loc. SOC. K-241, Enos Canyon, Yolo County, associated with Desmophyllites diphylloides and Metaplacenticeras sp. Loc. CAS. 1343, "north end of Pleasant Valley, Solano County, west side of the Sacramento Valley."

Subgenus Vertebrites MARShaLL, 1926

Type-species.-Vertebrites murdochi MARshald, 1926. 


\section{Gaudryceras (Vertebrites) kayei (FoRBEs)}

1846. Ammonites kayei Forbes, Trans. Geol. Soc. London, 2nd ser., vol. 7, p. 101, pl. 8, fig. 3 .

1865. Ammonites kayei, Stoliczka, Mem. Geol. Surv. India, Pal. Indica, ser. 3, vol. 1, p. 156, pl. 77, fig. 1, 1a (only).

1895. Lytoceras (Gaudryceras) kayei, Kossmat, Beitr. Pal. Geol. Oesterr.Ungarns Or., vol.9, p. 124 [28], p. 162 [66], pl.16 [2], fig. 5a, b; pl. 17 [3], fig. 2a, b.

1895. Lytoceras kayei Steinmann, N. Jahrb. Min. Geol. Pal., Beil. Bd. 10, p. 86 , pl. 5, fig. $5 \mathrm{a}, \mathrm{b}$; text-fig. 8 .

1907. Lytoceras (Gaudryceras) kayei, PÉRvinquière, Études de Paléont. tunisienne, I, Céph. terr. second., p. 69, pl. 3, fig. 20a, b.

? 1927. Gaudryceras kayei, Böse, Univ. Texas Bull. 2748, p. 269, pl. 10, figs. 10-14; pl. 11, figs. 5-10.

1949. Gaudryceras keyei, Collignon, Ann. Géol. Serv. Mines, Madagascar, fasc. 19 , p. 131.

1956. Vertebrites kayei, Coldignon, Ann. Géol. Serv. Mines, Madagascar, fasc.23, p. 64, pl. 6, fig. 4, 4a, 4 b.

? 1958. Lytoceras (Gaudryceras) kayei, Anderson, Geol. Soc. Amer., Memoir 71, p. 182.

1958. Lytoceras (Gaudryceras) coalingense ANDERson (pro parte), Geol. Soc. Amer., Memoï 71, p. 184, pl.68, fig. 1.

1958. Lytoceras (Gaudryceras) birkhauseri Anderson, Geol. Soc. Amer., Memoir 71, p. 185, pl. 68, fig. 4, 4a.

Holotype.-The single, illustrated specimen of ForBes (1846, pl. 8, fig. 3), BM. C. 51050. A plastercast has been kindly donated by the British Museum (Natural History) through Dr. M. K. HowarTh to Kyushu University.

Material.-The Californian specimens to be described herein are three:

(1) Holotype of Lytoceras (Gaudryceras) coalingense ANDERSON (1958, p. 184, pl. 68, fig. 1), from loc. CAS. 2362 (Coll. J. A. TAFF, C. C. Church, C. M. Cross, \& G. D. HanNa)

(2) Holotype of Lytoceras (Gaudryceras) birkhauseri ANDERson (1958, p. 185 , pl. 68 , fig. $4,4 a)$

(3) A specimen from loc. UC. B-4149 (Coll. Paleontology Class of UC and Monterey Peninsula College)

In Japan there are more numerous specimens which are of identical species with the Californian ones.

Measurements.-

Specimen Diameter

Height
9.5
18.5
25.0
19.0

Breadth (B/H)

Umbilicus (\%)

BM. C. 51050 (holotype)

32.5

$11.3 \quad(1.19)$

$17.5 \quad(54)$

Kossmat, 1895, pl. 3, f. 2

58.5

$18.0 \quad(0.97)$

$27.5 \quad(47)$

"coalingense"

73.0

One of Japanese example $61.0 \quad 19.0 \quad 20.0 \quad(1.05) \quad 29.5$ (48)

$22.5 \quad(0.90)$

$31.3 \quad(43)$

Descriptive remarks.- The holotype of G. (V.) kayei (ForBes) is a small, probably immature, specimen from Pondicherry, India. Studying more specimens from the same area, Kossmat (1895, p. 124 [28], 162 [66], pl. 16 [2], fig. 5a, b; pl. 17 [3], fig. 2a, b) described the species in detail. The specific diagnosis may be concisely written as follows: 
The shell is polygyral, growing very slowly. The umbilicus is wide, although the involution is nearly $1 / 2$. The whorl in the immature stage is reniform in section, broader than high, and broadest at the umbilical shoulder. The outer whorl is nearly as high as broad, with somewhat flattened flanks, increasing in height slightly more rapidly than the inner whorl. The surface of the shell is ornamented with numerous fine subcostae which are divided ventrally into more numerous, finer lirae. The subcostae and lirae are hardly impressed on the internal mould. The periodic constrictions are well marked, considerably prorsiradiate, especially near the umbilical margin, slightly flexuous on the side, and gently projected on the venter.

The Californian (and also Japanese) specimens have almost all the characters of the above diagnosis, but for one point. Kossmat's larger example of India shows flattened flanks and subangular umbilical shoulder on the outer whorl. The Californian (and Japanese) specimens have more rounded outer whorls and less angular umbilical shoulder than this Indian example. As can be observed on several Japanese specimens, however, the convexity of the flank and the roundness of the umbilical shoulder are somewhat variable, although the umbilical wall is steep, bending more or less abruptly from the flank. In the immature stage, as small as Forbes' original (holotype), no significant distinction can be found between the specimens of the Northern Pacific and the Indian provinces. The examples described from Chile (STEINMANN, 1895, p. 86, pl. 5, fig. 5a, b; text-fig. 8), Tunisia (PERvinquik̀re, 1907, p. 69, pl. 3, fig. 20a, b), Mexico (BösE, 1927, p. 269, pl. 10, figs. 10-14; pl. 11, figs. 5-10), and Madagascar (COLLIGNON, 1956, p. 64, pl. 6, fig. 4, 4a, 4b) are equally small.

The above distinction might imply subspecific difference between the forms of the different provinces. The distinction is, however, by no means significant. A new specific name, Lytoceras (Gaudryceras) coalingense, was proposed by ANDERSON (1958, p. 184, pl. 68, fig. 1) for one of the specimens under consideration. Another name, L. (G.) birkhauseri, was given (ANDERson, 1958, p. 185, pl. 68, fig. 4, 4a) for another crushed specimen, which is practically indistinguishable from $L$. (G.) coalingense. The name birkhauseri is, therefore, unnecessary, but coalingense should be used as a subspecific name, if subspecific separation was found to be justified. For a final decision I need more specimens from both India and California.

Occurrence.-Locs. CAS. 2361 and CAS. 2362, with Damesites hetonaiensis fresnoensis, Pachydiscus cf. egertoni, Anagaudryceras mikobokense, Baculites lomaensis, etc., Ragged Valley shale or "Pachydiscus siltstone" of Los Gatos Creek, Coalinga Quadrangle, Fresno County, west side of the San Joaquin Valley. Loc. UC. B-4149, with Pachydiscus egertoni and Anagaudryceras mikobokense, in the fairly higher part of the Panoche group, Ortigalita Peak Quadrangle, Merced County, west side of the San Joaquin Valley.

The type locality of $G$. (V.) kayci (ForBes) is the Valudayur beds ("Anisoceras" [recte Glyptoxoceras] beds) of Pondicherry, India. 
Genus Zelandites MARshall, 1926

Type-species.-Zelandites kaiparaensis MARSHALL, 1926, by original designation.

Synonym.-Varunaites SHImizU, 1926; Hypogaudryceras SHIMIZU, 1934; Anazelandites MAтSUмото, 1938 (all subjective synonyms; see WrIGHT and Matsumoto, 1954, p. 113).

Generic diagnosis.-See WRIGHT, 1957 (in MOORE [Editor], 1957), p. L200; Matsumoto, 1938b, p. 139.

Remarks.-Despite the wide distribution of the genus in the Indo-PacificMediterranean region, representatives of Zelandites in the Cretaceous of the West Coast of North America were not recorded in the previous literature. Aside from a poorly preserved Zelandites cf. inflatus MATSUMoto from loc. SOC. K-206, Roaring River, Ono area, Shasta County (Coll. M. V. KIRK), I have recognized only a single specimen in Mrs. SAUL's collection from Chico Creek.

\section{Zelandites sp. \\ Text-fig. 71}

Material.-A single, imperfectly preserved specimen, from loc. UCLA. 3648 (Coll. L. E. \& R. B. SAUL).

Descriptive remarks.-The shell is small, being $22.3 \mathrm{~mm}$. in diameter. The whorl is compressed and egg-shaped in cross section, with the maximum breadth somewhat below the middle of the flank. The proportion of breadth and height is similar to that of Zelandites kawanoi (JIMBo) (1894, p. 28, pl. 1, fig. 7; YABE, 1903, p. 41; Matsumoto, 1938b, p. 143 , pl. 14, figs. $3,4 a, b)$, with $b / h=0.77$ [breadth $=7.2$, height $=9.3 \mathrm{~mm}$.], but the whorl section of that Japanese Santonian species is elliptical with the maximum breadth at the middle of the flank. In this respect the Californian specimen is closer to Zelandites kaiparaensis Marshall (1926, p. 147, pl. 19, fig. 9, 9a; pl. 31, figs. 1, 2; Matsumoto, 1938b, p. 147, text-fig. 2), from the Campanian of New Zealand, which has the convergent whorl section. Z. kaiparaensis has, however, a wider umbilicus than the present form. In this specimen the umbilicus is about 24 per cent of the shell diameter $[u m b .=5.3$, diam. $=22.3 \mathrm{~mm}$.]. The surface is nearly smooth, but for a weak, prorsiradiate constriction.

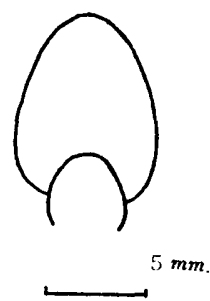

Fig. 71. Zelandites sp. Whorl-section of a specimen from loc. UCLA. 3648, Chico Creek, Butte County. 
To sum up the specimen under consideration is allied to, but not quite identical with, Z. kaiparaensis and Z. kawanoi. For accurate determination more specimens of better preservation are needed.

Occurrence.-Loc. UCLA. 3648, in the highest fossiliferous bed of the Chico formation exposed along Chico Creek, Butte County, east side of the Sacramento Valley. This is the first record of the occurrence of Zelandites in California.

\title{
Subfamily Tetragonitinae HYATT, 1900 \\ Genus Tetragonites Kossmat, 1895
}

Type-species.-Ammonites timotheanus PICTET, 1847

Synonym.-Epigoniceras SPATH, 1925 (see HowaRTH, 1958, p. 9; Matsumoto, 1959a, p. 78).

Generic diagnosis.-The shell is rather evolute to moderately involute. The whorl section is typically squarish, subquadrate or trapezoidal, but may be rounded on the venter. The surface is nearly smooth and usually constricted. The growth-lines and the constrictions are prorsiradiate on the flank, crossing the venter nearly vertically to the siphonal line or with a shallow backward sinus. The suture is of lytoceratid type, but has trifid saddles on both sides of the lateral lobe.

Remarks.-In the Upper Cretaceous of California there are at least two species of Tetragonites (s.s.), which are described below. The Cenomanian (plus Upper Albian) species which I have recorded from Japan and Alaska under the heading “Tetragonites sp. nov. (?)" (MAтsumoto, 1942c, p. 671; 1959a, p. 77, pl. 22, figs. 1a-c, 2a-c; text-fig. 15) is expected to occur in California, but I have seen only a few specimens from the Albian part.

Saghalinites Wright and MATsumoto, 1954 is best attached to Tetragonites as a subgenus. Typical examples have not yet been found in California, although the specimen which was described as Lytoceras (Tetragonites) henleyense ANDERsoN (1958, p. 185 , pl. 12 , fig. 5 , 5a; pl. 41, fig. 7 ) is apparently transitional to this subgenus.

\author{
Tetragonites glabrus (Јімво) \\ Pl. 39, figs. 2, 3a, b; Text-figs. 72,73
}

1894. Lytoceras glabrum JiмBo, Pal. Abh., Bd. 6 (N. F. 2), p. 180 [34], pl. 22 [6], fig. 2, 2a.

1902. Lytoceras (Tetragonites) jacksonense Anderson, Proc. Calif. Acad. Sci., 3rd ser., vol. 2, p. 82, pl. 5, figs. 124, 125.

1903. Tetragonites glabrus, YABE, Jour. Coll. Sci., Imp. Univ. Tokyo, vol.18, art. 2 , p. 43 , pl. 7 , figs. 2,5 .

1903. Tetragonites sphaeronotus, YABE (non JiмBo), Jour. Coll. Sci., Imp. Univ. Tokyo, vol. 18, art. 2, p. 45, pl. 7, fig. 1a, b.

1942. Epigoniceras glabrum, Matsumoto, Proc. Imp. Acad. Japan, vol.18, p. 672.

1958. Lytoceras (Tetragonites) jacksonense, ANDERson, Geol. Soc. Amer., Memoir 71, p. 186, pl.10, fig. 2, 2a. 
Holotype.-ЈІмво's original specimen (1894, pl. 22 [6], fig. 2, 2a), the body whorl of which is deformed. Cat. No. GT. I-111.

Material.-A considerable number of specimens from California and Oregon are referable to this species. Examples are:

CAS. No. 44, the holotype of Lytoceras (Tetragonites) jacksonense ANDERSoN (1902, pl. 5, figs. 124, 125) [=ANDERSON, 1958, pl. 10, fig. 2, 2a] (Text-fig. 73 in this paper), from loc. CAS. 445

UCLA. No. 28823, from loc. CIT. 1533 (Coll. W. P. Popenoe \& Carl Ahlroth)

A fragmentary outer whorl (Text-fig. 72), from loc. CIT. 1598 (Coll. W. P. Popenoe \& G. P. ZeBal)

A moderately large specimen, CIT. No. 3725 [=UCLA. 28859] (Pl. 39, figs. $2,3 a, b)$, the body whorl of which is crushed, from loc. CIT. 1346, with a label of T. jacksonense ANDERson (Coll. W. P. PoPENOE and Jane HoEL) A specimen from loc. UC. A-4866

There are other less perfectly preserved comparable specimens from locs. CIT. 1533, SOC. K-41, UCLA. 3371, UC. B-2040, and UC. A-7305.

\section{Measurements.-}

\begin{tabular}{lccrcrc}
\multicolumn{1}{c}{ Specimen } & Diameter & Height & \multicolumn{2}{c}{ Breadth (B/H) } & \multicolumn{2}{c}{ Umbilicus (\%) } \\
Holotype (at the last suture) & 51.1 & 24.2 & 26.5 & $(1.09)$ & 11.3 & $(22)$ \\
CAS. 44 (uncrushed part) & 42.5 & 20.0 & 21.5 & $(1.07)$ & 11.0 & $(26)$ \\
UCLA. 28823 & 30.0 & 14.5 & 15.5 & $(1.07)$ & 8.1 & $(27)$ \\
One from CIT. 1598 & - & 42.5 & 43.5 & $(1.02)$ & - & \\
CIT. 3725 [UCLA. 28859] & 45.0 & 22.0 & 22.0 & $(1.00)$ & 10.0 & $(22)$
\end{tabular}

Diagnosis.-The full-grown shell is of moderate size. The whorl grows rapidly, with a considerable overlapping. It is slightly broader than high or sometimes as broad as high, being broadest in the lower part, and subtetragonal in cross section, with subangular umbilical shoulders, gently convex and somewhat convergent flanks, and a rounded venter. The umbilicus is deep and fairly narrow, 22-27 percent of the diameter, and surrounded by the almost vertically wall.

The shell is thin, nearly smooth, with only lirae and some constrictions. The

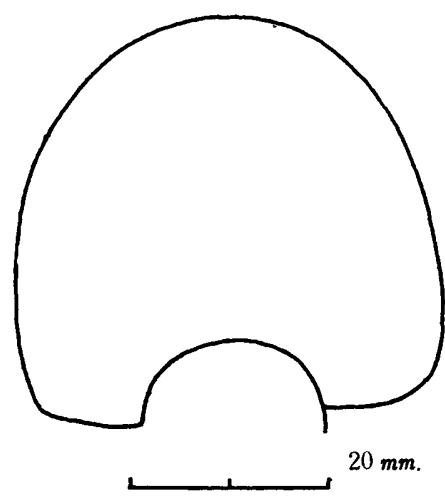

Fig. 72. Tetragonites glabrus (JімBO). Cross section of a fragmentary whorl, from loc. CIT. 1598, Member II of the Redding area, Shasta County. 
lirae are somewhat prorsiradiate on the flank and show a shallow, backward sinus on the venter. The constrictions vary in strength and frequency.

The suture is similar to that of Tetragonites epigonus Kossmat (1895, pl. 17 [3], fig. 4c).

Remarks.-The species occurs abundantly in the Upper Cretaceous (Turonian to Santonian, probably also lower portion of Campanian) of Hokkaido and South Sakhalin. The body whorl is, however, often secondarily deformed, as in the case of Jimbo's original specimens. Therefore T. glabrus has not been so correctly understood as it ought to be.

Studying the specimens of California and Oregon, as listed above, I am convinced of the specific identity between the forms of the east and west side of the northern Pacific region. The holotype of Lytoceras (Tetragonites) jacksonense ANDERSON (1902, pl. 5, figs. 124, 125) was illustrated as if its whorl was elliptical in cross section. This came again from the deformed state. The undeformed, septate part of the whorl has subangular umbilical shoulder and high, nearly vertical umbilical wall, as in the Japanese examples. The constrictions are very infrequent and indistinct on ANDERSON's specimen, as in many examples from Hokkaido and Sakhalin. In addition to the holotype of $L$. (T.) jacksonense, several other specimens from California show the characters quite identical with the diagnosis of T. glabrus. Therefore Lytoceras (Tetragonites) jacksonense ANDERSON, 1902 falls in the synonymy of Lytoceras glabrus JimBo, 1894.

I have described Epigoniceras glabrum var. problematica Matsumoto (1942c, p. 672, text-fig. 1a, b). As this represents an intermediate position between Tetragonites glabrus (s.s.) and T.popetensis $\mathrm{YABE}$, the subspecific ranking may be justified. The subspecies should be called Tetragonites glabrus problematicus and I here designate as lectotype the specimen illustrated in my previous paper (MATSUmoto, 1942c, text-fig. 1a, b), GT. "Cr. 503", from the Miho group, Naibuchi Valley, South Sakhalin. No example of this subspecies has yet been recognized

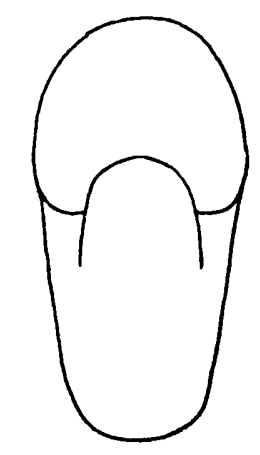

$15 \mathrm{~mm}$.

Fig. 73. Tetragonites glabrus (JімBO). Diagrammatic cross section of an example from Oregon, CAS. 44 [=holotype of Lytoceras (Tetragonites) jacksonense ANDERSON]. 
from California and Oregon. The occurrence of this subspecies in the basal part of the Campanian of Madagascar (Collignon, 1956, p. 89, pl. 11, fig. 5, 5a, $5 b$ ) is very interesting. In connection with this wide distribution it cannot be overlooked that Tetragonites beantalyensis CoLLIGNON (1956, p. 83, pl. 10, fig. 1, 1a, 1b) from the Coniacian of Madagascar is almost indistinguishable from immature T. glabrus and that T. embergeri ColLIGNoN (1956, p. 84, pl. 10, figs. $2,2 \mathrm{a}, 2 \mathrm{~b}, 3,3 \mathrm{a}, 3 \mathrm{~b})$ is also very closely allied to T. glabrus.

Occurrence.-Locs. CAS. 445, "Forty-nine mine", Oregon; CIT. 1346, Member III of the Redding area; CIT 1533 and CIT. 1598, Member II of the same area, California. Comparable specimens are from loc. CIT. 1533, SOC. K-41, and UCLA. 3371, Member II of the Redding area; UC. B-2040, Romaniceras locality, Venado conglomeratic sandstone at the dam of Putah Creek, Solano-Napa County boundary; and UC. A-4866, Venado sandstone equivalent near Fruto, Glenn County. All of these are referable to the Turonian. There is another locality, UC. A-7305, in Venado sandstone, north of Cache Creek, Yolo County, where Tetragonites sp. was found.

\section{Tetragonites popetensis YABE}

Text-fig. 74

1903. Tetragonites popetensis YABE, Jour. Coll. Sci., Imp. Univ. Tokyo, vol.18, art. 2, p. 48, pl. 7, figs. 4 a, b. 6 .

1942. Epigoniceras popetense, Matsumoto, Proc. Imp. Acad. Japan, vol.18, p. 672.

1958. Lytoceras (Tetragonites) kernense ANDERson, Geol. Soc. Amer., Memoir 71 , p. 187 , pl. 32 , fig. 4 ; pl. 73 , fig. 6 .

1958. Lytoceras (Tetragonites) epigonum, ANDERSON (non KosSMAT), Geol. Soc. Amer., Memoir 71, p. 187, pl.65, figs. 4, 5; pl. 67, fig. 3, 3a.

? 1958. Lytoceras (Tetragonites) henleyense ANDERson, Geol. Soc. Amer., Memoir 71 , p. 185, pl. 12, fig. 5, 5a; pl. 41, fig. 7 .

Holotype.-GT. I-207, one of the figured specimens of YABE (1903, pl. 7, fig. $4 \mathrm{a}, \mathrm{b}$ ), from Shisanushibe, Hokkaido, by original designation.

Material.-The following Californian examples are referred to this species:

(1) Specimens from loc. CAS. 1552, including the holotype and paratype of Lytoceras (Tetragonites) kernense ANDERSON (1958, p. 187, pl. 32, fig. 4 ; pl. 73, fig. 6) (Coll. G. D. HANNA and J. H. SHow)

(2) Many specimens from loc. CAS. 2362, including the hypotypes of Lytoceras (Tetragonites) epigonum of ANDERSON (non KOSSMAT) (1958, p. 187, pl. 65, figs. 4, 5) (Coll. C. C. CHURCH) (Text-fig. 74 in this paper)

(3) Specimens from loc. CAS. 2361 (Coll. C. C. Church)

(4) A specimen from loc. CAS. 29102, hypotype of Lytoceras (Tetragonites) epigonum of ANDERSON (1958, pl. 67, fig. 3, 3a) (Coll. Allan BENNISON)

(5) Specimens from locs. LSJU. 3345 [=TM. 507] and LSJU. 3343c [=TM. 509c] (Coll. M. B. PAYNe \& T. MATsumoto) 
Measurements.-

\begin{tabular}{cccrrr} 
Specimen & Diameter & Height & \multicolumn{2}{r}{ Breadth (B/H) } & Umbilicus (\%) \\
GT. I-207 (after YABE) & 34.0 & 14.5 & $15.0(1.03)$ & $10.5(31)$ \\
ANDERSON, 1958, pl. 65, f. 4 & 33.0 & 14.3 & $14.8(1.03)$ & $10.0(30)$ \\
ANDERSON, 1958, pl. 65, f. 5 & 33.2 & 13.8 & $14.6(1.05)$ & $9.1(27)$ \\
ANDERSON, 1958, pl. 12, f. 5 & 43.3 & 16.1 & $17.2(1.06)$ & $15.7(36)$
\end{tabular}

Diagnosis.-The shell is relatively small. The whorls grow rather slowly, with involution of about $1 / 2$. The umbilicus is of moderate width, being about $30( \pm 3)$ per cent of the sheli diameter. The whorl is parallel sided, with gently convex and somewhat flattened flanks, a gently rounded venter, an abruptly bent umbilical shoulder, and a vertical umbilical wall. It is thus, subquadrate in cross section, the height being not much different from breadth, except in the very early growth-stage.

The surface is nearly smooth, with very fine growth-lines, and fairly frequently constricted. The growth-lines and the constrictions are remarkably prorsiradiate on the flank, crossing the venter with a slight backward sinus and with decreased intensity.

The suture is similar to that of Tetragonites epigonus Kossmat (1895, p. 135 [39], pl. 17 [3], fig. 4c).

Remarks.-This species resembles Tetragonites epigonus Kossmat (1895, p. 135 [39], pl. 17 [3], figs. 4a-c, 5a, b), but is distinguished by its parallel, not convergent, flanks (cf. Text-fig. 74 with Text-fig. 75), smaller involution, and generally wider umbilicus.

As I have mentioned (Matsumoto, 1942c, p. 672-3), there are a few intermediate forms in Japan.

Although ANDERSON (1958, p. 187, pl. 65, figs. 4, 5; pl. 67, fig. 3, 3a) referred certain Californian specimens to $T$. epigonus, they are better assigned to $T$. popetensis. Similarly Lytoceras (Tetragonites) kernense ANDERsoN (1958, p. 167, pl. 32, fig. 4 ; pl. 73, fig. 6) cannot be separated from T. popetensis. ANDERsoN's holotype is given in his measurements as higher than broad, but the specimen itself is secondarily deformed. Otherwise it is indistinguishable from T. popetensis. It should, therefore, be called Tetragonites $\mathrm{cf}$. popetensis YABE.

The holotype of Lytoceras (Tetragonites) henleyense ANDERSON (1958, p. 185 , pl. 12 , fig. 5 , $5 \mathrm{a}$; pl. 41 , fig. 7 ) is very close to $T$. popetensis. The only difference is its wider umbilicus. From ANDERson's measurements the umbilicus is 41 percent of the shell diameter, but in my measurements it is 36 percent.

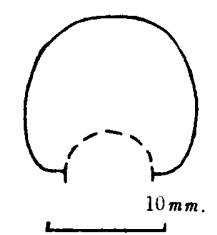

Fig. 74. Tetragonites popetensis YABE. Whorl-section of a Californian example [=T. epigonum, ANDERSON 1958, pl. 65, fig. 4 (non KosSMAT)], from loc, CAS. 2362, Los Gatos Creek, northwest of Coalinga, Fresno County. 


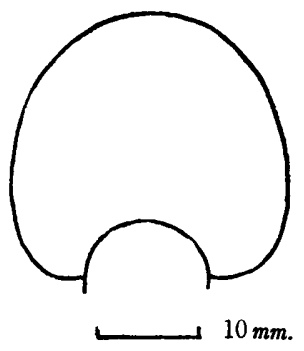

Fig. 75. Tetragonites epigonus Kossmat. Whorl-section, shown for comparison with that of T. popetensis YABE (Fig. 74). Adapted from KossmaT, 1895.

Therefore the difference from the normal examples of $T$. popetensis is by no means great. This specimen may be a mere variant, or a subspecies of $T$. popetensis that would represent a transitional state to Tetragonites (Saghalinites). To determine which is the case more specimens from the type locality, CAS. 444, are needed. ANDERson's assignment to the Coniacian is not tenable, because the associated species, Metaplacenticeras pacificum (SмIтH) and Desmophyllites diphylloides (FORBES), indicate the Upper Senonian, probably Upper Campanian.

Occurrence.-The species does not seem uncommon in California. Loc. CAS. 1552, north end of Shale Hills, Kern County, southwest side of the San Joaquin Valley, where Desmophyllites diphylloides and Baculites rex are associated. Loc. CAS. 2362, "Pachydiscus silt" or Ragged Valley shale of Los Gatos Creek, northwest of Coalinga, west side of the San Joaquin Valley; also loc. CAS. 2361, presumably the same formation in Joaquin Rock Quadrangle, west side of the above two localities, there are Damesites hetonaiensis fresnoensis, Gaudryceras (Vertebrites) kayei (FORBES), Pachydiscus cf. egertoni, and Baculites lomaensis. Locs. LSJU. 3343c and LSJU. 3345, Los Gatos Creek, not far from loc. CAS. 2362. Loc. CAS. 29102, "Garzas limestone" in Volta Quadrangle, Merced County, west side of the San Joaquin Valley.

In Hokkaide and Sakhalin the species is common in the Upper Senonian (Campanian and Maestrichtian) [= Hetonaian plus Uppermost Urakawan].

\section{Genus Pseudophyllites Kossmat, 1895}

Type-species.-Ammonites indra ForBes, 1846.

Generic diagnosis.-See WrIGHT, 1957 (in MooRE [Editor], 1957), p. L203.

Remarks.-This genus is widespread in the Indo-Pacific region. In California, so far as I know, it is represented by a few imperfectly preserved specimens, as briefly described below.

\section{Pseudophyllites cf. indra (FORBES)}

Compare.-

1846. Ammonites indra Forbes, Trans. Geol. Soc. London, 2 ser., vol. 7, p. 105, pl. 11, fig. 7 . 
1865. Ammonites indra, Stoliczka, Mem. Geol. Surv. India, Pal. Indica, ser. 3, vol. 1, p. 112, pl. 18, fig. 2a, b.

1879. Ammonites indra, Whiteaves, Geol. Surv. Canada, Mesozoic Fossils, vol. 1, pt. 2, p. 105, pl. 13, fig. 2, 2a.

1895. Pseudophyllites indra, Kossmat, Beitr. Pal. Geol. Oesterr.-Ung. Or., vol. 9, p. 137 [41], pl. 16 [2], figs. 6-9; pl. 17 [3], figs. 6, 7; pl. 18 [4], fig. 3.

1904. Lytoceras indra, Boule, Lemoine, and Thevenin, Ann. Paléont., vol. 1., p. 2, pl. 1, fig. 1, 1a, 1b.

1906. Pseudophyllites cf. indra, Woods, Ann. South Afr. Museum, vol. 4, p. 334, pl. 41, fig. 6a, b.

1909. Pseudophyllites indra, KILliAN and ReBoul, Wiss. Erg. Schwed. Südpolar Exp., 1901-1903, vol. 3, no. 6, p. 14, fig. 3 .

1938. Pseudophyllites indra, Collignon, Ann. Géol. Serv. Mines, Madagascar, vol. 9, p. 24, text-fig. E.

1952. Pseudophyllites indra, Usher, Geol. Surv. Canada, Bull. 21, p. 57, pl. 3, figs. 2-13, pl. 31, figs. 15-17.

1956. Pseudophyllites indra, Collignon, Ann. Géol. Serv. Mines, Madagascar, vol. 23 , p. 90 .

Material.-Imperfectly preserved specimens, from loc. UC. A-6598 (Coll. S. G. Clark) and loc. UCLA. 2415 (Coll. L. E. SAUL), in California.

Descriptive remarks.-As understood from the descriptions of previous authors (see above list of synonymy), Pseudophyllites indra shows some variation in the proportion between whorl-breadth and height and in the roundness of the venter. The specimen from loc. UC. A-6598 resembles one of the specimens from the Nanaimo group of British Columbia (Usher, 1952, pl. 3, figs. 11-13). Another specimen, from loc. UCLA. 2415, can be compared with the example from the Catarina formation. The last mentioned, No. 4247 (CAS.), was once erroneously regarded as an example (not the holotype) of Pachydiscus catarinae ANDERson and HANnA (1935, p. 19, pl. 3, figs. 2, 3). This is close to the typical examples of Pseudophyllites indra (FoRBEs) from India but has more evenly rounded venter. In this respect it approaches Pseudophyllites peregrinus SPATH (1953, p. 7, pl. 1, figs. 6-9) from Graham Land and from Madagascar (CollignoN, 1956, p. 92, text-fig. 12), but its whorl is not so broad as in the typical examples of $P$. peregrinus. The Californian material at my disposal is unfortunately too poor for further discussion.

Occurrence.-Loc. UC. A-6598, west of Kelly Creek, Covelo Quadrangle, Mendocino County. Loc. UCLA. 2415, in an isolated outcrop of the Cretaceous strata in El Toro Quadrangle, with Anapachydiscus cf. arrialoorensis, Metaplacenticeras cf. pacificum, and Baculites cf. rex.

According to COLLIGNON (1956, p. 91) Pseudophyllites indra ranges from the boundary of Santonian-Campanian, all through the Campanian, to the Lower Maestrichtian.

Family Turrilitidae MEEK, 1876

Species belonging to the Turrilitidae occur sparsely in California and Oregon. 
They have been described by GABB (1864, 1869) and ANDERson (1958). I have examined some of their original specimens and only a few of other collections, so I give here concise remarks.

As the types are missing I cannot give comments on Turrilites oregonensis GABB (1869, p. 138, 213) [= Turrilites sp. indet. in GABB, 1864, p. 73, pl. 28, fig. 201]. There are, however, several in the subsequent collections from central Oregon, which are labelled as Turrilites oregonensis. Those from locs. USGS. 7533 and USGS. 3658, Oregon, are characterized by acute tubercles and cannot be distinguished from Turrilites acutus PASSY, 1832 [= Turrilites wiestii SHARPE, 1857].

I sought in vain ANDERSON's (1958, p. 194) specimen of Turrilites oregonensis, from a locality west of Coalinga ("Coll. G. D. HANNA"), but I have seen Turrilites (Euturrilites) cf. scheuchzerianus BoSC, 1801 [=T. desnoyersi D'ORBIGNY, 1841] in Dr. S. W. MulleR's collection, from loc. LSJU. 2747, west of Coalinga, Fresno County, California. This came from the "Lower Waltham shale", associated with Acanthoceras cf. evolutum SpATH.

The holotype of Turrilites pachecoensis ANDERSON (1958, p. 193, pl. 11, fig. 4), from loc. CAS. 27858, Quinto Creek, Stanislaus County, west side of the San Joaquin Valley, California, is a fragmentary whorl of Turrilites costatus LAMARCK (D'ORBIGNY, 1840, p. 598, pl. 145). ANDERSON's retouching of the picture is misleading. Two other fragmentary whorls which are comparable with T. costatus came from loc. LSJU. 2959, north of Walthan Creek, Coalinga area, associated with Forbesiceras cf. obtectum (SHARPE) (Coll. G. W. MoORE) ; another example of $T$. costatus from loc. CAS. 33729, east of Oakland, Bay area.

The holotype of Turrilites petersoni ANDERson (1958, p. 193, pl. 12, fig. 6; pl. 75, fig. 4) is a fragmentary whorl, but there are better preserved specimens from the type locality, Peterson ranch, Colusa County, California, in the collections of the University of California and the Shell Oil Company (Coll. M. V. KIRK). This species is an excellent example of Pseudohelicoceras, indicating the Upper Albian together with the associated species.

Turrilites bergeri of ANDERSON (1958, p. 193, pl. 11, fig. 2) certainly belongs to Mariella (s.s.), but probably not to $M$. bergeri (BRONGNIART). It has more oblique, more numerous ribs and smaller tubercles than that species. In other words it is closely allied to, if not quite identical with, M. miliaris (PICTET and Campiche) (see Spath, 1937, p. 514). According to Anderson (1958) it came from loc. CAS. 31097, on Dry Creek, northwest side of the Sacramento Valley. Among the associated specimens I identify Desmoceras (Pseudouhligella) poronaicum YABE, but the coexistence of Sciponoceras kossmati (NowAK) [= Cyrtochilus stylus ANDERson, 1958] is questionable.

Stuart CHUBER has kindly let me borrow his specimens obtained from the Cretaceous area of Fruto and Lodoga Quadrangles, west side of the Sacramento Valley. I identify among others Mariella (Plesioturrilites) sp. So far as I know, this is the first discovery of Plesioturrilites in California. The details of its stratigraphic occurrence will be described by CHUBER. Representatives 
of Plesioturrilites have been known in the Lower Cenomanian of Texas.

Turrilites excelsus ANDERSON (1958, p. 194, pl. 72, fig. 4) is not a Turrilites but a Nostoceras (see below).

Family Nostoceratidae Hyatт, 1894

Species referable to Nostoceratidae and Diplomoceratidae are not rare in the Upper Cretaceous of California and adjacent areas, but the specimens are often too fragmentary for accurate identification. ANDERSON (1902, 1958) established a large number of species, but his (and also GABB's) types are often so imperfectly preserved that I cannot give full revisions. I describe herein only five selected species, two of Nostoceratidae and three of Diplomoceratidae, which are noteworthy.

Before entering on their description, I should like to give short remarks on some of the genera and species. I have recognized in the Upper Cretaceous of California examples of the genera Bostrychoceras НуатT, 1900, Hyphantoceras Нyатт, 1900 Didymoceras HYaтt, 1894, Nostoceras Hyat,, 1894, Pseudoxybeloceras Wright and Matsumoto, 1954 Solenoceras ConRad, 1860, Scalarites Wright and Matsumoto, 1954 Glyptoxoceras Spath, 1926, Diplomoceras HyatT, 1900, Polyptychoceras YABE, 1927 (rare), and Ryugasella WRIGHT and MATSUмото, 1954. The first four genera belong undoubtedly to Nostoceratidae and the last five to Diplomoceratidae. Solenoceras and Pseudoxybeloceras are probably referred to Nostoceratidae. In addition to the above ANDERSON (1958, p. 201) proposed Exicrioceras, but I doubt its distinction from Exiteloceras HYATT, 1900. Certain examples which were assigned to Exiteloceras by ANDERSON, e.g. $E$. vancouverense (GABB) (1864, p. 70, pl. 13, fig. 18) may be merely U-shaped body whorls of Nostoceras or Didymoceras.

Heteroceras hornbyense WhiteAves (1903, p. 332, pl. 42, figs. 1-4) was assigned to Nostoceras by USHER (1952, p. 103, pl. 27, figs. 1, 2; pl. 28, fig. 2; pl. 31, fig. 23) and ANDERSON (1958, p. 195), but should be better referred to Didymoceras, because the bituberculation is not well developed on the whorl of the early growth-stage, and because the large later whorls do not touch and pass gradually (not abruptly) into a large, retroversal body whorl. This species is widespread from Vancouver Island to Baja California. It is closely allied to an undescribed species of Didymoceras from the Campanian of the Western Interior and another, D. awajiense (YABE) from the Campanian of Japan.

Incidentally Didymoceras HYATT, 1894 might be a synonym of Cirroceras CONRAD, 1868, as WRIGHT (in MOORE [Editor], 1957, p. L224) considered. The type-species of the latter, Ammonceratites conradi MoRTon, 1841, is based on so imperfectly preserved specimen that the identity of the two genera is hardly to be satisfactorily decided. Therefore, I prefer to use the better defined Didymoceras.

The specimen which was designated as the holotype of Turrilites excelsus ANDERSON (1958, p. 194, pl. 72, fig. 4), from loc. CAS. 29123, is, in my opinion, 
an example of Nostoceras splendidum (SHUMARD) (1861, STEPHENSON, 1941, p. 415, pl. 82, figs. 1-4), which occurs commonly in the Nacatoch sand of the Navarro group. This suggests some connection between the Gulf Coastal and Californian provinces. The probable connection is also supported by the occurrence of Solenoceras in both provinces. In fact $S$. mexicanum ANDERSON (1958, p. 211, pl. 72, fig. 8) from Baja California is indistinguishable from $S$. reesidei Stephenson (1941, p. 401, pl. 77, figs. 1-3) from the Navarro group. Contrary to ANDERSON's observation, the periodic constrictions are discernible on the Baja Californian and also the Californian specimens.

Hyphantoceras seems to occur at various levels in the Upper Cretaceous of California and Oregon. The available specimens are unfortunately all fragmentary, but some are comparable with the Japanese species. YABE already mentioned the close affinity of Hyphantoceras venustum (YABE, 1904) with Hyphantoceras ceratopse (ANDERSON, 1902). They might be identical, but the illustrated type (ANDERSON, 1902, pl. 3, figs. 100, 101) of $H$. ceratopse was lost and a recovered portion (ANDERSON, 1958, pl. 39, fig. 7) is too fragmentary and does not clearly show the tubercles. A single, fragmentary specimen, the holotype of Bostrychoceras buttense ANDERSON (1958, p. 207, pl. 51, fig. 7, 7a), from loc. CAS. 28173, Chico Creek, is probably within the variation of Hyphantoceras venustum. The specimen, from loc. CAS. 31115, north of Rumsey, which was described as Hyphantoceras laqueum ANDERSON (1958, pl. 210, pl. 31, fig. 3) resembles one of YABE's originals (YABE, 1904, p. 11, pl. 3, fig. 4) of $H$. venustum. The latter specimen is not quite identical with the holotype of $H$. venustum (YABE, 1904, p. 11, pl. 5, figs. 1, 2), being somewhat transitional to H. reussianum. This and the holotype of $H$. laqueum ANDERSON can be still included within $H$. venustum, although laqueum might be validated as a subspecific name. There is another Californian example of this kind of $H$. venustum, which came from loc. CAS. 33699, Member IV of the Redding area. The holotype of $H$. venustum came from the Santonian of Hokkaido, while YABE's other original specimen, probably came from either the Coniacian or the Turonian. There are typical examples of $H$. venustum in California, from loc. UCLA. 3791 (Coll. W. P. Popenoe), upper part of Member $\mathrm{V}$ or lower part of Member VI of the Redding area, and from loc. CIT. 1016 (Coll. W. P. POPENOE \& D. SharF), relatively lower part of the Chico formation on Chico Creek. There are several fragmentary specimens of Hyphantoceras sp. indet. from Members II, III (Turonian), and IV (Coniacian) of the Redding area.

The holotype of Didymoceras orestimbense ANDERSON (1958, p. 197, pl. 45, fig. 4) is a good example of Hyphantoceras oshimai (YABE) (1904, p. 12, pl. 3, figs. 5, 6) (non YABE, 1915, p. 18, pl. 1, fig. 1a, b). Therefore ANDERSON's specific name is again unnecessary.

Genus Bostrychoceras HyatT, 1900

Type-species.-Turrilites polyplocus ROEMER, 1840. 
Diagnosis.-The whorls are spiral, typically contiguous, forming a turreted shell like Turrilites, but are sometimes slightly separated, and followed by a free, retroversal body whorl. The whorl is rounded, being subcircular to elliptical in section.

The shell is ornamented with numerous, normally simple oblique and slightly sinuous ribs. There is a collared constriction along the apertural margin of the adult body whorl.

The suture is florid, deeply and finely incised; $\mathrm{L}$ is much larger than $\mathrm{E}$ and deeply cut into two unequal branches, $U$ is similar to but smaller than $L$; $I$ is small and normally trifid; saddles are bifid.

Remarks.-The typical example of Bostrychoceras is B. polyplocum (ROEMER) as figured by ScHLÜTER (1872, p. 112, pl. 33, figs. 3, 4). There are, however, three doubtful points about the extent of the genus, the first relating to the tubercles, the second to the constrictions, and the third to the mode of coiling. ScHLürer included bituberculate and loosely spiral specimens in B. polyplocum, admitting great variability of that species. As the bituberculate specimens occur in the same bed as the nontuberculate ones, his conclusion might be correct, but the former may be merely examples of Didymoceras. To clear this doubt the European material must be studied. Anyhow the species from California and adjacent areas, e.g. B. elongatum (WHITEAVES) (1903, p. 331, pl. 44, fig. 2; UsHer, 1952, p. 105, pl. 28, figs. 3, 4; pl. 31, fig. 24), B. declive (GABB) (1864, p. 73, pl. 28, fig. 200, 200a; ANDERSON, 1958, p. 207, pl. 52, fig. 2, 2a), and $B$. aff. otsukai (YABE), described below, have no tubercles at all.

Bostrychoceras polyplocum has no periodic constrictions but only the collared constriction along the apertural margin of the adult body whorl. B. elongatum, $B$. declive, and $B$. otsukai likewise have no periodic constrictions. In certain other species, such as B. indicum (SToliczKA) (1865, p. 184, pl. 86, figs. 1, 2; Kossmat, 1895, p. 143 [47], pl. 20 [6], figs. 5a-c, 6), B. woodsi (KITCHIN) (1922, p. 49; WooDs, 1896, p. 75, pl. 2, figs. 6-8), and B. japonicum (YABE) (1904, p. 17, pl. 3, fig. 8; non 1915, p. 17, pl. 1, figs. 4-6) there are constrictions (sometimes collared) even on the septate whorls. While these constricted species are Turonian or Lowęr Senonian in age, the non-constricted ones are not older than Santonian. Therefore the separation, at least in subgeneric rank, of the former from the latter may be taxonomically desirable. An example of the constricted subgroup in America is B. serpiens ANDERSON (1958, p. 204, pl. 20, figs. 3, 4, 7), from "SMITH [FITCH] ranch", Oregon.

The last species is peculiar in that the initial sinistral, coiling is described as turning to dextral coiling in the course of the ontogenetic development. Unfortunately the original specimen (ANDERSON, 1902, pl. 9, figs. 96, 97; 1958, pl. 20, figs. 3, 4), is missing and this point cannot be reexamined. A similar feature is noticed in B. punicum PERVINQUiÈre (1907, p. 103, pl. 4, figs. 20, 21a, b), but was considered as being accidental by PERvinquiÈre. In a Japanese species from the Upper Turonian and Coniacian, though not yet fully described, a similar peculiar feature can be constantly recognized. Otherwise this Japanese 
example is very similar to $B$. indicum. In the hitherto described specimens of $B$. indicum from India and those of $B$. woodsi from England, this particular point has not be noticed. Their preservation, however, does not seem to be so perfect as to allow the inspection of the very initial coil. According to $\mathrm{C}$. W. WRIGHT (personal communication, May 1959), he has a specimen, probably of B. woodsi, which suggests the same phenomenon. A similar feature seems to occur in some Hyphantoceras, as indicated by Fritsch and SchloENBACH (1876, pl. 14, fig. 15 and pl. 15, fig. 9). In the already described, Turonian and Coniacian species of Bostrychoceras the mode of coiling of the adult body-whorl has not been well known, probably due to the imperfect preservation. In a better preserved Japanese example the last whorl does not show so distinctly a retroversal U-shape as in $B$. polyplocum, but only tends to be separated from other whorls.

From these grounds the separation of the Turonian and Lower Senonian species from the Santonian and later ones seems to be still more reasonable. But this is not the place to propose a new name, because the American specimens which I dealt with are not satisfactory preserved. I must suspend the proposal until I describe the Japanese species.

\author{
Bostrychoceras sp. aff. B. otsukai (YABE) \\ Pl. 40, fig. 2a, $b$
}

Compare.-

1894. Turrilites sp., Jiмвo, Pal. Abh., Bd. 6 (N.F. 2), p. 187 [41], pl. 17 [1], fig. $8,8 \mathrm{a}$.

1904. Heteroceras (?) otsukai YABE, Jour. Coll. Sci., Imp. Univ. Tokyo, vol. 20, art. 2, p. 14, pl. 4, figs. 1,2 ; pl. 6 , fig. 7.

1904. Heteroceras (?) otsukai var. multicostata YABE, Jour. Coll. Sci., Imp. Univ. Tokyo, vol. 20, art. 2, p. 16, pl. 3, fig. 9 ; pl. 4 , fig. 3 ; pl. 6, fig. 8.

1938. Bostrychoceras otsukai, Collignon, Ann. Géol. Serv. Mines, Madagascar, fasc. 9, p. 37, pl. 6, fig. 2, 2a, $2 \mathrm{~b}$.

Holotype of B. otsukai.-GT. I-243 (YABE, 1904, pl. 4, fig. 1), from Hokkaido.

Material.-The Californian specimens which I describe under this heading are UCLA. 28846 (P1. 40, fig. 2a, b), from loc. UCLA. 3370 (Coll. John Frick), and other, less perfectly preserved ones from locs. UCLA. 3623 and UCLA. 3627 (Coll. L. E. \& R. B. SAUL).

Measurements.-

\begin{tabular}{|c|c|c|c|c|}
\hline Specimen & Diameter & Height & Breadth & $(\mathrm{B} / \mathrm{H})$ \\
\hline $\begin{array}{l}\text { UCLA. } 28846 \\
\text { (each } 1 / 2 \text { vol.) }\end{array}$ & $\begin{array}{l}\text { c. } 70 \\
\text { c. } 80\end{array}$ & $\left\{\begin{array}{l}21.0 \\
24.3 \\
26.5\end{array}\right.$ & $\begin{array}{l}24.0 \\
29.5 \\
33.0\end{array}$ & $\begin{array}{l}(1.14) \\
(1.21) \\
(1.24)\end{array}$ \\
\hline
\end{tabular}

Description.-The shell is turreted, consisting of somewhat separated whorls, growing rather slowly; the early whorl makes a considerably narrower coil than the middle, which however is only slightly narrower than the later. They are rounded and thickly elliptical in cross section.

The whorl is ornamented with numerous ribs, about 40 in a half volution. The ribs are uniform, mostly simple, rarely bifid or inserted, and arranged slightly obliquely. They are narrow and sharp on the shell, but more blunt on 
the internal mould, separated by the interspaces only slightly broader than the ribs themselves.

The suture, which is partly exposed, is quite similar to that of $B$. otsukai (YABE, 1904, pl. 6, figs. 7, 8 in which the symbol as [antisiphonal] was misplaced at the bottom of $U$ ).

The preserved last whorl is still septate. Therefore the adult shell must be fairly large.

Remarks.-From the observed characters the Californian specimens are comparable but not quite identical with Bostrychoceras otsukai (YABE) (1904, p. 14, pl. 4, figs. 1, 2; pl. 6, fig. 7). The Californian representative has more numerous and more crowded ribs than the Japanese holotype, although the ribs themselves are equally narrow. In this respect it closely resembles $B$. otsukai var. multicostata (YABE) (1904, p. 16, pl. 3, fig. 9; pl. 4, fig. 3; pl. 6, fig. 8), but it is not so loosely coiled as that "variety". In the mode of coiling it is more similar to the holotype of $B$. otsukai.

If ample material could be acquired, the Californian representative might prove to be subspecifically separable from the Japanese. For the time being it is called Bostrychoceras aff. B. otsukai (YABE).

Occurrence.-Loc. UCLA. 3370, upper part of Member V, or "close to the contact of Members V and VI", of the Redding area, Shasta County; locs. UCLA. 3623 and UCLA. 3627, lower part of the Chico formation in the section of Chico Creek, Butte County, east side of the Sacramento Valley. From the stratigraphic position and associated species they are probably referred to the Santoinan. The Japanese holotype came from the Santonian of Hokkaido.

\section{Genus Pseudoxybeloceras WRight and Matsumoto, 1954}

Type-species.-Hamites quadrinodosus Jімво, 1894 (by original designation).

Diagnosis.-The early part of the shell may be openly helicoid, followed by flattened elliptical coiling in one plane, consisting of straight and parallel, longer arms and U-shaped, curved parts. The arms are separated. The later whorl is typically more or less compressed.

The shell is ornamented with simple, fine, slightly oblique ribs, each of which has upper or upper and lower ventrolateral, small spines. Major ribs are absent in the typical species, but may infrequently develop on some others.

The suture consists of E, L, U, and I, with all elements florid, bifid, deeply and finely incised, and approximately equal, except for I which is trifid and smaller than others.

Remarks.-After the establishment of this genus by WRIGHT and Matsumoto (1954, p. 119) I had opportunities of studying better preserved specimens of the type-species from Hokkaido. A revised definition is given above.

Ancyloceras lincatum GABB, described below, is probably to be referred to this genus. It has infrequent and weak, major ribs, on which the minor ribs from a loop at the tubercles. Similar but stronger, major ribs develop in a 
Japanese species, Neocrioceras (?) sanushibense WRIGHT and MATsumoto (1954, p. 121, pl. 7, fig. 5a, b; text-fig. 22), which is apparently transitional between Neocrioceras and Pseudoxybeloceras. "Oxybeloceras" petrolense ANDERSON (1958, p. 203, pl. 56, fig. 1) may be another example of Pseudoxybeloceras which has a few major ribs only on the curved portion, but otherwise is close to $P$. quadrinodosum. Mr. C. W. WRIGHT (a letter of Sept. 10, 1958) has shown me a photograph of another interesting specimens from the Turonian of England which is also transitional between Nencrioceras and Pseudoxybeloceras.

From the above observations Pseudoxybeloceras is better attached to Nostoceratidae than to Diplomoceratidae. Oxybeloceras HYATT, 1900, without constriction, and Solenoceras CoNRAD, 1860, with collared constriction, are close to Pseudoxybeloceras, but their arms are in contact. Exiteloceras HYATT, 1894 is elliptically coiled, without straight parts, and has somewhat irregular ribbing and only upper ventrolateral tubercles. Probably Exiteloceras and Pseudoxybeloceras are in parallel or sister relationship. Neocrioceras SPATH, 1921 may be more closely related to Pseudoxybeloceras than WRIGHT and MATsumoto (1954) once considered. The ultimate origin of these genera may be in a plastic genus Hyphantoceras HYATT, 1900, but the actual lineages of the evolution are not yet precisely known.

In Japan Pseudoxybeloceras is proved to be long ranging, from the Upper Turonian to the Campanian. It seems to be widespread in the Campanian, because probable representatives are recognized in California (here mentioned), Pondoland of southeast Africa, and New Zealand (see Wright and Matsumoto, 1954, p. 120).

\author{
Pseudoxybeloceras lineatum (GABB) \\ Pl. 40, fig. 1a-d; Pl. 41, fig. 1a-c; Text-figs. 76-79
}

1869. Ancyloceras ? lineatum GABB, Palaeont. Calif., vol. 2, p. 139, pl. 23, fig. 18, $18 \mathrm{a}, \mathrm{b}, \mathrm{c}$.

1958. Oxybeloceras lineatum, Anderson, Geol. Soc. Amer., Memoir 71, p. 202.

? 1958. Oxybeloceras taffi ANDERSon, Geol. Soc. Amer., Memoir 71, p. 203, pl. 51, fig. 6, 6a.

Types.-GABB (1869) based this species on two syntypes. The illustrated one (Pl. 40, fig. 1a-d; Text-fig. 76 of this paper), now preserved in the Museum of Comparative Zoölogy, Harvard University, is here designated as the lectotype.

Material.-In addition to the lectotype, I refer the following specimens to the present species.

LSJU. 8579 (Pl. 41, fig. 1a-c; Text-fig. 79), from loc. LSJU. 2609 (Coll. R. E. CoOK) ; a specimen (Text-fig. 77) from loc. UCLA. 3637 (Coll. L. E. \& R. B. SAUL); another (Text-fig. 78) from loc. CAS. 1467A (Coll. RAMBKE); another fragment from loc. CIT. 83 (Coll. B. M. MoORE); others from loc. CIT'. 1400 [Sucia Island] (Coll. R. Durbin \& W. P. POPENOE) 
Measurements.-

\begin{tabular}{|c|c|c|c|c|}
\hline Specimen & Height & Breadth $(\mathrm{B} / \mathrm{H})$ & Distance & $\frac{\text { Number of ribs }}{\text { Distance }}$ \\
\hline Lectotype & $\left\{\begin{array}{l}22.4 \\
21.8\end{array}\right.$ & $\left.\begin{array}{ll}18.0 & (0.80) \\
16.3 & (0.75)\end{array}\right\}$ & 31.0 & $14 / 31$ \\
\hline $\begin{array}{l}\text { One from loc. } \\
\text { UCLA. } 3637\end{array}$ & $\left\{\begin{array}{l}9.4 \\
7.8\end{array}\right.$ & $\left.\begin{array}{ll}\overline{6.3} & (0.81)\end{array}\right\}$ & 40.0 & $10 / 12$ \\
\hline $\begin{array}{l}\text { Another from loc. } \\
\text { CIT. } 1400\end{array}$ & $\left\{\begin{array}{l}9.0 \\
8.3\end{array}\right.$ & $\left.\begin{array}{ll}7.9 & (0.88) \\
7.5 & (0.90)\end{array}\right\}$ & 20.0 & $12 / 10$ \\
\hline
\end{tabular}

Description.-No perfectly preserved specimen has been found. The smallest fragment among the available specimens is curved, suggesting that the early whorl is openly helicoid or almost crioceroid. The specimen of the next growthstage is broadly arcuate, suggesting a flattening elliptical coil. The later whorl, as seen in a specimen, LSJU. 8579, consists of two, long and straight, parallel arms and a curved, U-shaped part, lying in one plane. The lectotype probably represents a part of this straight arm, which is still septate. A complete outline of the body whorl is not yet known.

The whorl is somewhat higher than broad, being elliptical in section. It is ornamented with numerous, fine, entire ribs, which are separated by the interspaces slightiy broader than the ribs themselves. They are prorsiradiate; more so on the earlier whorl, showing a moderate sinus on the dorsum; only slightly oblique or nearly vertical on the straight arm of the late whorl. Each rib has a small, spinose, ventrolateral tubercle. On the later whorl a few, low, and indistinct major ribs are infrequently recognized, on which the tubercles are larger than the others and the minor ribs form a loop at the tubercle. In addition, a faint, lower ventrolateral node is sometimes, but not always, discernible on the major rib. It is not confirmed in the lectotype.

The suture is as described in the generic diagnosis.

Remarks.-From all the observable characters this species is best referred to Pseudoxybeloceras. It has a more elliptical, in stead of polygonal, whorl section than P. quadrinodosum (JIMBo) (1894, p. 185 [39], pl. 23 [7], figs. 3, 4) (WRIGHT and Matsumoto, 1954, p. 120, pl. 7, fig. 6a, b; text-figs. 6, 9-12). The latter species has upper and lower ventrolateral tubercles on each rib of its later whorl, while the lower ventrolateral tubercles are only occasionally discernible on the major

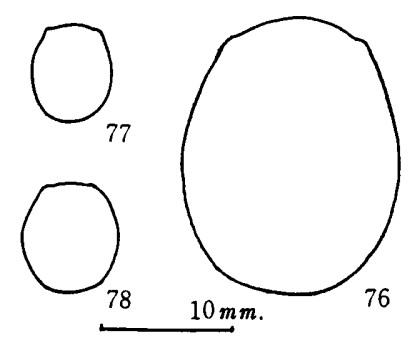

Figs. 76-78. Pseudoxybeloceras lineatum (GABB). Cross sections of three specimens.

76. Lectotype in the collection of MCZ. Harvard. See P1. 40, fig. 1a-d.

77. An example from loc. UCLA. 3637, Chico Creek, Butte County.

78. Another from loc. CIT. 1400, Sucia Island, Washington. 


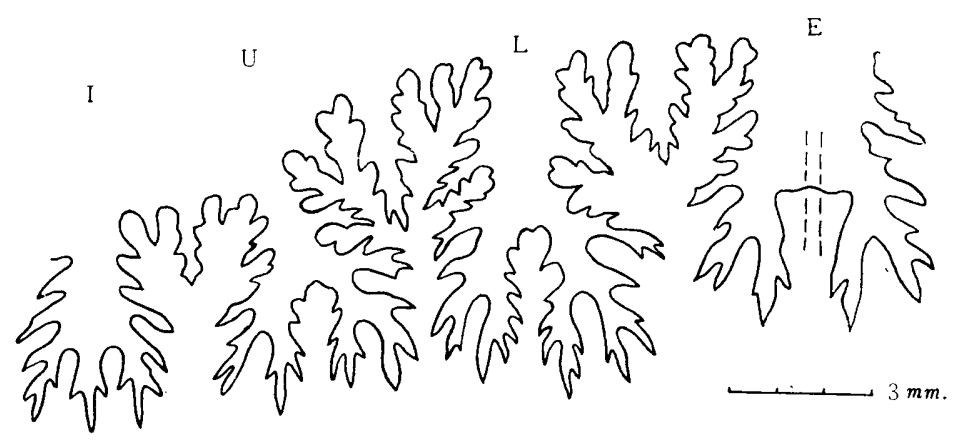

Fig. 79. Pseudoxybeloceras lineatum (GABB). Suture near the curved part of an example, LSJU. 8579, from loc. LSJU. 2609, Chico Creek, Butte County. See Pl. 41, fig. 1a-c for other views.

ribs of the former. The major ribs are absent in $P$. quadrinodosus, but appear on the later whorl of $P$. lineatum, although they are faint and infrequent. The major rib and looping of the minor ribs at the tubercles remind us of the ornament of Neocrioceras spinigerum (Jімво) (1894, p. 184 [38], pl. 24 [8], fig. 1, 1a, 1b) and also of $N$. (?) sanushibense Wright and Matsumoto (1954, p. 121, pl. 7, fig. 5a, b; text-fig. 22). N. (?) sanushibense is close to $P$. lineatum in that it has a straight arm, but it has more constant, quadritubercles, stronger major ribs, and broader whorls. It may represent a transitional state between $\mathrm{Neo-}$ crioceras and Pseudoxybeloceras.

The holotype of Oxybeloceras taffi ANDERSON (1958, p. 203, pl. 51, fig. 6, 6a), from loc. CAS. 27838, Chico Creek, may be a fragment of the present species. It is, however, too poorly preserved for concluding definitely the synonymy of taffi with lineatum.

Occurrence.-The type locality is recorded as "Texas Flat Coral near Folsom," east side of the Sacramento Valley. Other localities of subsequent collections are clearer. Locs. LSJU. 2609 and UCLA. 3637, both in the lower part of the upper half of the section of the Chico formation in Chico Creek, Butte County, east side of the Sacramento Valley, where this species is associated with Submortoniceras chicoense and Baculites chicoensis. Loc. CAS. 1467A, Enos Canyon, Yolo County, west side of the Sacramento Valley, where Desmophyllites diphylloides, Metaplacenticeras pacificum, etc. occur. Loc. CIT. 83, calcareous sandstone at the top of the Holz shale, Santa Ana Mountains, Orange County. Loc. CIT. 1400, Nanaimo group of Sucia Island, Washington, where Desmophyllites diphylloides and Hoplitoplacenticeras sp., among others, occur. To sum up, P. lineatum occurs at various levels in the Campanian of the West Coast.

\section{Family Diplomoceratidae SPATH, 1926}

There are representatives of Scalarites WRIGHT and MATSUmoto, 1954, Glyptoxoceras SPATH, 1926, and Ryugasella WRIGHT and MATSUmoto, 1954 in the Upper Cretaceous of California and adjacent areas, as described below. 
While Polyptychoceras YABE, 1927 [type-species, Anisoceras pseudogaultinum YoKOYAMA, 1890, by subsequent designation of SHIMıZU, 1935a, p. 271] occurs abundantly in Hokkaido and Sakhalin, it is very rare on the West Coast of America. Ptychoceras vancouverense Whiteaves (1879, p. 113, pl. 14, fig. 3, 3a; Usher, 1952, p. 101, pl. 26, fig. 5, 6), from the Trent River formation of the Nanaimo group, is probably an example of Pclyptychoceras, close to P. pscudogaultinum (YoKоYама) (1890, p. 181., pl. 20, figs. 1-3). "Hamites obstrictus" of Whiteaves (1903, p. 334, pl. 44, fig. 3) and Usher (1952, p. 100, pl. 26, fig. 7), from the upper Lambert formation of the Nanaimo group, is not referable to the true Polyptychoceras obstrictum (JiмBo) (1894, p. 184 [38], pl. 23 [7], fig. 2, 2a, 2b). Shimizu (1935a, p. 272) wrongly assigned this Japanese species to Diplomoceras and incorrectly recorded it as Maestrichtian. The Nanaimo species is probably to be referred to Diplomoceras, close to D. tenuisulcatus (ForBES) (1846, p. 116, pl. 11, fig. 3). Diplomoceras is represented by the better known D. notabile Whiteaves (1903, p. 335, pl. 44, fig. 4, 4a, 4b; Usher, 1952, p. 109, pl. 29, fig. 2 ; pl. 30, fig. 1 ; pl. 31, figs. 26,27 ), from the same upper Lambert formation. More species of Diplomoceras have been recorded by ANDERson (1952) from California, although some are indefinite and doubtful.

\section{Genus Scalarites Wright and Ma'Tsumoto, 1954}

Type-species.-Helicoceras scalare YABE, 1904.

Generic diagnosis.-See Wright and Matsumoto, 1954, p. 115.

Remarks.-Scalarites is close to Glyptoxoceras SPATH, 1925 and also to Diplomoceras HYATT, 1900. Flared ribs and constrictions occur more frequently in Scalarites. Perhaps there is some distinction in the mode of coiling. Scalarites shows very shallow open helicoid spire followed by loose elliptical coiling. Glyptoxoceras typically has more closed, Bostrychoceras-like helix in the initial growth-stage, a less elliptical, crioceras-like coiling in the middle, and a U-shaped last whorl. Diplomoceras has two or three, subparallel, straight or broadly curved shafts, in addition to the initial, loose helicoid spire. Its suture is more florid than that of Scalarites. Polyptychoceras YABE, 1927 has three or four, parallel, straight and long shafts which are approximated or nearly in contact with each other. It is similar to Scalarites in suture. From the stratigraphic occurrence and morphological characters of various species, Glyptoxoceras, Diplomoceras, and Polyptychoceras are probably derived from Scalarites, which in turn, is probably a descendant of a nontuberculate subgroup of Hyphantoceras.

Although the specimens at my disposal are fragmentary, I have recognized a probable representative of Scalarites in California.

\section{Scalarites cf. mihoensis WRIGHT and MATSUmoto}

Pl. 37, fig. 3

Compare.-

1954. Scalarites mihoensis WRIGHT and MATSUmoto, Mem. Fac. Sci., Kyushu 
Univ., ser. D, vol. 4, p. 118, pl. 7, figs. 1, 2; text-fig. 2 .

Types.-Holotype of S. mihoensis is GT. I-2951a (WRIGHT and MATSUmoto, 1954, pl. 7, fig. 1) by original designation. It is immature and is supplemented by several paratypes. These types came from the Upper Turonian and the Coniacian of South Sakhalin and Hokkaido.

Material.-A figured specimen (Pl. 37, fig. 3), UCLA. 28780, and other ten fragmentary whorls of different sizes from loc. CIT. 1532 (Coll. W. P. PoPENoE \& Carl Ahlroth) ; several fragments from locs. CIT. 1533 (Coll. W. P. PoPenoe \& Carl Ahlroth) and CIT. 1346 (Coll. W. P. Popenoe \& Jane Hoel).

Measurements.-

\begin{tabular}{|c|c|c|c|}
\hline Specimen & Height & Breadth $(B / H)$ & $\frac{\text { Number of ribs }}{\text { Distance nearly equal to height }}$ \\
\hline One from loc. CIT. 1532 & 2.9 & $2.6 \quad(0.89)$ & $5 / 3.0$ \\
\hline $\begin{array}{l}\text { Another from loc. } \\
\text { CIT. } 1532\end{array}$ & $\left\{\begin{array}{l}8.9 \\
9.2\end{array}\right.$ & $\left.\begin{array}{ll}7.8 & (0.88) \\
8.2 & (0.89)\end{array}\right\}$ & $9 / 9.0$ \\
\hline Another $" ~ " \prime \prime$ & 9.5 & $8.1 \quad(0.85)$ & $7 / 9.0$ \\
\hline Another " $"$ " & 11.7 & $10.0(0.85)$ & $8 / 11.0$ \\
\hline UCLA. 28780 & - & - & $9 / 10.0$ \\
\hline
\end{tabular}

Descriptive remarks.-Some of the fragmentary whorls show broadly arcuate parts and others more strongly curved; U-shaped portions, thus indicating elliptical coiling of $S$. mihoensis type. The section of the undeformed whorl is subcircular to broadly elliptical, slightly higher than broad, with the antisiphonal area more broadly rounded than the siphonal area on the later whorls.

The annular ribs are fairly numerous, of moderate strength, relatively narrow, and separated by broader interspaces. The periodic, flared ribs, with associated constriction, are less frequent than those of S. scalaris (YABE) (1904, p. 9, pl. 3, figs. 2, 3a-c).

From all the observable characters the described specimens of California are best referred to $S$. mihoensis WRIGHT and MATSUmoto.

The holotype of Hamites ellipticus ANDERSON (1902, p. 87, pl. 3, figs. 102, 103; pl. 10, fig. 191), from "Forty-nine Mine, Oregon" apparently resembles Scalarites mihoensis in the curvature of the whorl and the mode of ribbing. There are doubtful, infrequent constrictions. This is probably an example of Scalarites, although ANDERSON (1958, p. 198, pl. 39, fig. 5, 5a) recently referred it to Diplomoceras. ANDERSON's holotype is more compressed than the normal examples of $S$. mihoensis.

Occurrence.-Locs. CIT. 1532 and CIT. 1533, Member II (near the top) of the Redding area; loc. CIT. 1346, Member III (Subprionocyclus normalis bed) of the same area, Shasta County, northeast side of the Sacramento Valley.

\section{Genus Glyptoxoceras SPATH, 1926}

Type-species.-Hamites rugatus ForBEs, 1846. Since this nominal species was originally designated as the "genotype" of Glyptoxoceras (SPATH, 1925, p. 30), it is the type-species, despite the fact that Hamites (Anisoceras) rugatus 
of Kossmat (1895, non Forbes) has been shown by SHIMIZU (1835, p. 272) to be a synonym of Glyptoxoceras indicum (ForBes, 1846).

Generic diagnosis.-See SHIMIZU, 1935, p. 272; WRIGHT in MooRE [Editor], 1957, p. L227.

Remarks.-SHIMIZU (1935, p. 272) accounted the asymmetrically bifid antisiphonal lobe (I) as a criterion by which to distinguish this genus from other allied genera, but this should not be stressed too much, because the character is variable and not important. Normally I is trifid, but may be modified, especially on the curved or helicoid part.

The relationship of Glyptoxoceras with Scalarites, Diplomoceras, and Polyptychoceras has been mentioned above (see p. 165).

Glyptoxoceras ranges from Santonian to Maestrichtian. The type-species occurs in the Valudayur beds of the Pondicherry area, southern India.

The similarity of Glyptoxoceras to Heternceras D'ORBIGNY, 1849 of the Barremian and Aptian is an example of homeomorphy. Glyptoxoceras shows bilateral symmetry in its later growth-stages.

\section{Glyptoxoceras indicum (FoRBES), 1846 \\ Pl. 41, figs. 2-6; Text-fig. 80}

1846. Hamites indicus Forbes, Trans. Geol. Soc. London, 2 ser., vol. 7, p. 116. 1895. Hamites (Anisoceras) indicus, Kossmat, Beitr. Pal. Geol. Oesterr.Ungarns Or., vol. 9, p. 145 [49], pl. 19 [5], fig. 4a-c.

1895. Hamites (Anisoceras) rugatum, Kossmat (non Forbes), Beitr. Pal. Geol. Oesterr.-Ungarns Or., vol. 9, p. 146 [50], pl. 19 [5], fig. 7a, b, 9 (8a, b doubtful).

1935. Glyptoxoceras indicum, ShImizu, Proc. Imp. Acad. Sci., vol. 11, p. 272.

Types.-Forbes based this species on several syntypes (see KossmAt, 1895, p. 145 [49]). The illustrated specimen of Forbes (1846, pl. 11, fig. 4), which was erroneously called the holotype by SHIMIZU (1935, p. 272), has been removed from Hamites indicus to Hamites subcompressus (see Kossmat, 1895, p. 145; SHimizu, 1935a, p. 272) . Another of ForBes' syntypes, BM. 1049b, was illustrated by Kossmat (1895, pl. 19 [5], fig. 4a, b). This is designated here as the lectotype of Glyptoxoceras indicum (FORBES). It was incorrectly called a paratype and misrecorded as BM. 10498 by SHIMIZU. (1935a). The specimen with register number BM. 10498 is the illustrated syntype of Hamites largesulcatus ForBES (1846, pl. 11, fig. 1).

Material.-Five specimens, UC. $36433-36437$ (Pl. 41, figs. 6, 2, 4, 5, 3; Textfig. 80), from loc. UC. A-3826 (Coll. Allan BENNISON), which altogether give us the correct shape of the shell. Other fragmentary pieces, from loc. LSJU. 2251 [ $\fallingdotseq$ LSJU. 3326], are comparable with the present species.

Diagnosis.-The initial coils are helicoid, relatively closed, soon followed by a crioceroid, planospiral coil, and finally passing into an elliptical coil, up to the broadly U-shaped, last part. The main part is, thus, hilaterally symmetric. The longer diameter of the last ellipse is about $75 \mathrm{~mm}$. to $85 \mathrm{~mm}$.; the shorter one about $55 \mathrm{~mm}$. to $65 \mathrm{~mm}$. The whorl is nearly circular in section, slightly 
higher than broad in the later whorls; about $15 \mathrm{~mm}$. to $20 \mathrm{~mm}$. in height of the last part.

The shell is ornamented with numerous, regular, annular ribs. They are moderately elevated, fairly sharp on the shell, and slightly radial, but are somewhat curved on the helical whorl and may be slightly oblique on the strongly curved part. There is a collared constriction along the apertural margin.

The suture is finely and deeply incised. The saddles and lobes are bifid, except for a normally trifid I. $\mathrm{E}$ is smaller than $\mathrm{L}$; the saddle between $\mathrm{L}$ and $\mathrm{U}$ is the largest; $\mathrm{I}$ is the smallest of all.

Remarks.-The Californian specimens conform in essential features with the Indian types. From the latter Wright and Matsumoto (1954, text-fig. 5) restored the complete shell. The restored illustration is proved to be generally correct from the Californian material too, although the initial helical whorls are actually more tightly coiled and more closed than that figure.

The low, helical, initial coiling, similar to that of the present species, is shown in at least two specimens of "Hamites" tenuisulcatus ForBes (1846, p. 116, pl. 11, fig. 3; Kossmat, 1895, pl. 19 [5], fig. 5a, b) from India. The helical whorls are, however, more loosely separated in $H$. tenuisulcatum than in $G$. indicum. H. tenuisulcatus has a very long, almost straight part, following the crioceras-like part, as can be seen in another syntype, BM. 10493 (ForBEs, 1846, pl. 10, fig. 8), which I designate here the lectotype of $H$. tenuisulcatus. The last U-shaped part is not preserved in this lectotype. This species has distinctly finer, more densely crowded ribs than $G$. indicum. Hamites tenuisulcatus is, thus, very possibly referable to Dinlomoceras, to which Diplomoceras notabile

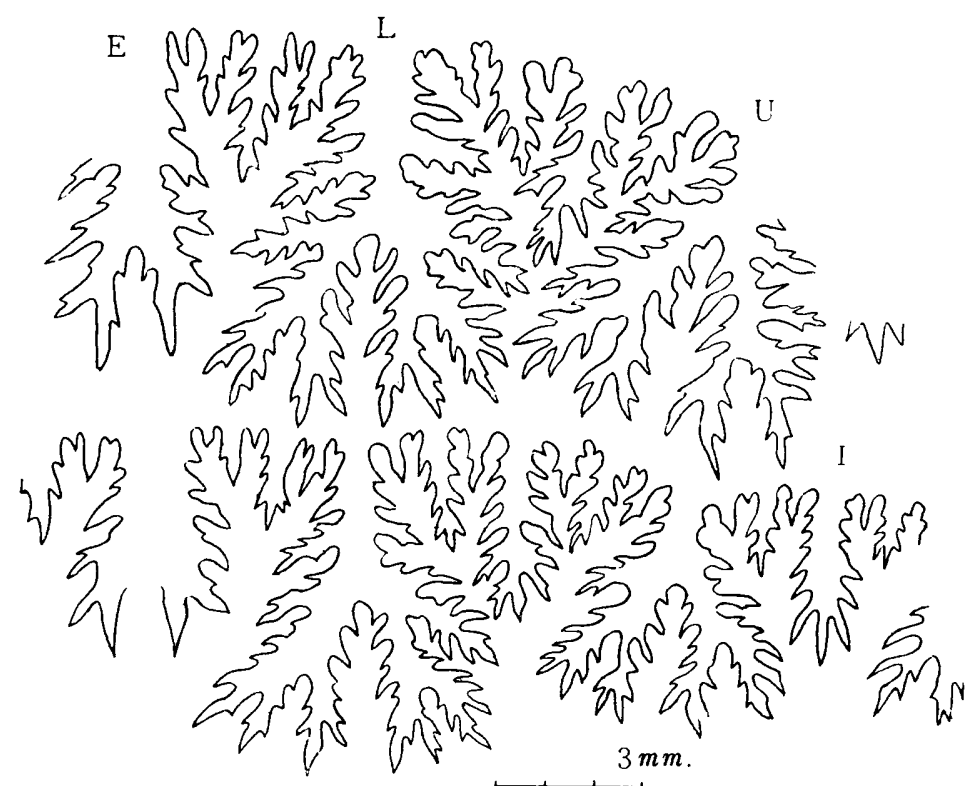

Fig. 80. Glyptoxoceras indicum (ForBes). Sutures of an example from loc.

UC. A-3826, Wildcat Canyon, Ortigalita Peak Quadrangle, Fresno County. 
Whiteaves (1903, p. 335, pl. 44, fig. 4, 4a, 4b; Usher, 1952, p. 109, pl. 29, fig. 2; pl. 30, fig. 1; pl. 31, figs. 26, 27) is closely allied.

Glyptoxoceras rugatum (FoRBES) (1846, p. 117, non pl. 11, fig. 2; SHIMIZU, 1935a, p. 273, text-figs. 1-9) have coarser ribs than G. indicum. G. subcompressum (FoRBES) (1846, p. 116, pl. 11, fig. 6a-c; Kossmat, 1895, p. 145 [49], pl. 19 [5], fig. 10a, b) has the ribs which are as narrow as, but more widely spaced than, those of G. indicum. It has a compressed, elliptical section. Two of its syntypes, BM. 10491 and BM. 10492, figured separately by ForBes and KossmAT, are parts of a long, broadly arcuate shell, which is larger than the broadly arcuate part of G. indicum. There are probable examples of G. subcompressum in the Nanaimo group of Vancouver Island (WhiteAVES, 1903, p. 338, pl. 45, fig. 1, 1a, 1b; UsHeR, 1952, p. 110, pl. 29, fig. 3). In California G. subcompressum is represented by many, fragmentary specimens, from loc. UC. B-4149, in a bed with Pachydiscus cf. egertoni and Anagaudryceras mikobokense.

Glyptoxoceras (?) largesulcatum (ForBES) (1846, p. 117, pl, 11, fig. 1) has a thickly elliptical cross section in the relatively later whorl, as represented by the illustrated type of ForBes (BM. 10498). In this respect it is fairly similar to $G$. indicum, but has much more widely spaced, sharper ribs than that species. I doubt the distinctness of $G$. circulare SHImizU (1935a, p. 272, text-figs. 10, 11), because its holotype, with a subcircular cross section, seems to me to be merely an earlier part of $G$. (?) largesulcatum. Anyhow, this species is still indefinite, because its mode of coiling is not exactly known. Several fragmentary specimens in the collection of Professor MULLER from loc. LSJU. 3355, "Pape place", on Mill Creek, Tehama County, east side of the Sacramento, may be comparable with G. (?) largesulcatum, but are by no means certain.

Occurrence.-Loc. UC. A-3826, Wildcat Canyon, Ortigalita Peak Quadrangle, Fresno County, west side of the San Joaquin Valley. This locality is referred to the upper part of the Panoche group by PAYNE (1951, map of pl. 1). Another locality, LSJU. 2251, is at top of the same group in the type Panoche Hills, west side of the San Joaquin Valley.

The types in India came from the Valudayur beds of the Pondicherry district.

Genus Ryugasella. WRight and Matsumoto, 1954

Type-species.-Ryugasella ryugasensis WRIGHT and Matsumoto, 1954.

Generic diagnosis.-See Wright and Matsumoto, 1954, p. 122.

Ryugasella ryugasensis WRIGHT and MATSUmoto, 1954

Pl. 37, fig. 4a-c

? 1890. Anisoceras cf. rugatum, Yoxoyama (non ForBes), Palaeontographica, vol. 36, p. 183 , pl. 20 , fig. 8.

1954. Ryugasella ryugasensis Wright and Matsumoto, Mem. Fac. Sci., Kyushu Univ., ser. D, vol. 4, p. 122, pl. 7, fig. 4a-d; text-figs. 7, 13 A-E. 
Holotype.-GT. I-2862 (W'Right and Matsumoto, 1954, pl. 7, fig. 4a-d), from the Campanian of Sakhalin, as originally designated.

Material.-A long, but still imperfect, specimen, LSJU. 8579 (Pl. 37, fig. 4a-c), from loc. LSJU. 2609 (Coll. R. E. CooK) ; several fragmentary specimens of dissimilar sizes, from loc. UCLA. 3637 (Coll. L. E. \& R. B. SAUL).

Measurements.-

\begin{tabular}{|c|c|c|c|}
\hline Specimen & Height & Breadth $(\mathrm{B} / \mathrm{H})$ & Distance \\
\hline LSJU. 8579 & $\left\{\begin{array}{l}16.0 \\
12.0\end{array}\right.$ & $\left.\begin{array}{ll}15.5 & (0.97) \\
11.8 & (0.98)\end{array}\right\}$ & 110.0 \\
\hline UCLA. 28820 & 12.1 & $12.1 \quad(1.0)$ & \\
\hline UCLA. 28821 & $\left\{\begin{array}{r}10.1 \\
8.5\end{array}\right.$ & $\left.\begin{array}{ll}9.8 & (0.97) \\
8.1 & (0.95)\end{array}\right\}$ & 45.0 \\
\hline UCLA. 28822 & 5.5 & $5.3 \quad(0.96)$ & \\
\hline
\end{tabular}

Description.-Among five pieces of imperfectly preserved specimens, only one, probably immature shell, is slightly arcuate; others are almost straight, with slow tapering. The shell is nearly circular in cross section, almost as high as broad or slightly higher than broad. The last septum is found at about the height (i.e. longer diameter in cross section) of $14 \mathrm{~mm}$. in a probably mature example, in which the body chamber of about $80 \mathrm{~mm}$. long is preserved. The mode of coiling (or uncoiling) in the initial stage is still unknown.

The ribs are simple, very regular, of moderate density, narrow, moderately elevated, and separated by somewhat broader interspaces. They cross the entire surface of the shell with uniform intensity. They are prorsiradiate on the flank, broadly convex on the venter, and show a moderate sinus on the dorsal area. Constrictions are scarcely observable on the available fragments; only an indistinct one on the septate part of the longest specimen has been seen.

The suture consists of E, L, U, and I. The elements are inverse trapezoidal in general outline and moderately incised. The saddles and the lobes are bipartite, except for I, which is small, narrow, and tripartite.

Remarks.-In all the observable characters the described specimens from California are undoubtedly referable to Ryugasella ryugasensis WRIGHT and Matsumoto. The illustrated specimen, LSJU. 8579 (Pl. 37, fig. 4a-c) is better preserved than the holotype from Sakhalin. The above description may, thus, supplement the description of WRIGHT and MATSUmoto (1954, p. 122).

Ryugasella ryugasensis has some affinity with Polyptychoceras obstrictum (JIMBo) (1894, p. 184 [38], pl. 23 [7], fig. 2, 2a, 2b) and also with Scalarites mihoensis WRIGHT and MATSUmoto (see p. 165 in this paper) in cross section, simple ribbing, and sutures. Probably Ryugasella is a straightening offshoot of Diplomoceratidae, derived either from Scalarites or from Polyptychoceras. No transitional species, however, have been found.

Superficial resemblance can be noted between $R$. ryugasensis and certain species of Lechites, such as L. communis SPATH (1941, p. 666, text-fig. 244). In the former the ribs are not weakened and show a sinus on the dorsal area. There should be a difference in the aperture of the shell, although the apertural margin of $R$. ryugasensis is not known. The constriction, although very in- 
frequently, occurs in $R$. ryugasensis, but never in Lechites. Since Lechites is proved to be a derivative of Hamites, the resemblance between Ryugasella and Lechites is an example of heterochronous homemorphy.

Occurrence.-Locs. LSJU. 2609 and UCLA. 3637, in the upper part of the Chico formation in the type section of Chico Creek, Butte County, east side of the Sacramento Valley. This species is associated with Submortoniceras chicoense and Baculites chicoensis.

\section{Family Scaphitidae MEEK, 1876}

On the West Coast of North America species belonging to the Scaphitidae do not occur so abundantly as in the Western Interior province. ANDERson (1902, 1908) established seven species, but some of his original specimens were lost in the San Francisco fire. The specimens obtained by subsequent collections are not numerous, except those by Dr. POPENOE and his associates from the Redding area, Shasta County. I had not enough time for studying carefully Dr. PoPenOE's specimens, so I give here only brief comments on ANDERson's species.

Scaphites condoni ANDERSON (1902, p. 111, pl. 2, figs. 58-63; 1958, p. 249, pl. 24, fig. 6, 6a-e) is a well defined species. It is very closely allied to Scaphites planus YABE (1910, p. 167, pl. 15, figs. 11-18), but is distinguished by a more inflated shell and a coarser ornament. As YABE has pointed out, S. planus YABE shows a great variation. Therefore some of its extreme variant is indeed very close to $S$. condoni, especially to $S$. condoni var. appressus ANDERSON (1902, p. 112, pl. 2, figs. $64-65 ; 1958$, p. 250), but a study of more specimens from America is needed for concluding the specific identity of S. condoni and S. planus. Anyhow I doubt ANDERson's age determination of $S$. condoni as Cenomanian. Turonian is suggested from the occurrence of the closely allied $S$. planus in Japan.

I cannot give comments on Scaphites roguensis ANDERSON (1902, p. 112, pl. 2, figs. 67-70), because its original specimens were lost and because the original illustration is too sketchy.

Similarly I cannot mention much about Scaphites gillisi ANDERSON (1902, p. 110, pl. 3, figs. 85-88), as his syntypes were not at my disposal. From the description and illustration, however, $S$. gillisi seems to be very closely allied to Scaphites pseudoaequalis YABE (1010, p. 163, pl. 15, figs. 1-3) from the Turonian and the Coniacian of Japan.

Scaphites pittensis ANDERSON (1958, p. 252, pl. 19, fig. 4, 4a) is also allied to S. pseudoaequalis, but is similar to Scaphites warreni MEEK and HAYDEN (see CoBBAN, 1951, p. 21, pl. 3, figs. 8-21) in that the ventral ribs are more widely spaced on the straight part than on the curved part of the living chamber. The holotype of ANDERson's species came from loc. CAS. 1293A, probably Member II (Turonian) of the Redding area.

I do not agree with ANDERSON (1958, p. 252) in referring the fragmentary specimens from loc. CAS. 31209, presumably Sites formation in Yolo County, 
west side of the Sacramento Valley, to Scaphites hippocrepis (DEKAY). The diagnostic ornament of the living chamber of $S$. hippocrepis is not recognized in the Californian specimens.

I agree with YABE (1910, p. 170) in regarding Scaphites inermis ANDERsoN (1902, p. 113, pl. 3, figs. 74-77) as identical with Scaphites puerculus Jimbo (1894, p. 37, pl. 5, fig. 4), which is an example of Otoscaphites WRIGHT, 1953. ANDERSON's holotype was lost and the neotype proposed by ANDERSON (1958, p. 251, pl. 27, fig. 1, 1a-c), from loc. CIT. 1010, near the base of Member II of the Redding area, Shasta County is weakly ornamented as JimBo's holotype of o. puerculus. This Japanese species includes a more strongly ornamented variety. Scaphites klamathensis ANDERSON (1902, p. 115, pl. 3, figs. 78-81) may be merely such a variety of $O$. puerculus. Unfortnnately its original types were lost, but some of the recently obtained specimens are identified with $O$. puerculus. In Japan O. puerculus occurs in the Turonian and the Coniacian. The Californian examples, which occur in Members I and II of the Redding area, are probably Turonian. In addition I have recognized several examples of $O$. puerculus from locs. LSJU. 1997 and 1999 (Coll. Kirby), presumably Sites or Funks formation of the Rumsey area, west side of the Sacramento Valley.

Scaphites perrini ANDERSON (1902, p. 114, pl. 2, figs. 71-73) can be regarded as a depressed example of Otoscaphites, but may be still debatable, as WRIGHT (1953, p. 476) has pointed out. The holotype came from "SMith ranch" [= FITCH ranch], Oregon and is now preserved at Stanford University. This species occurs in the Japanese Turonian and Coniacian.

Part III to be continued 